\title{
Plant Species of Concern and Plant Associations of \\ Powder River County, Montana
}

Prepared for the

Bureau of Land Management

by

Bonnie Heidel, Catherine Jean and Susan Crispin

Montana Natural Heritage Program

Natural Resource Information System

Montana State Library

October 2002

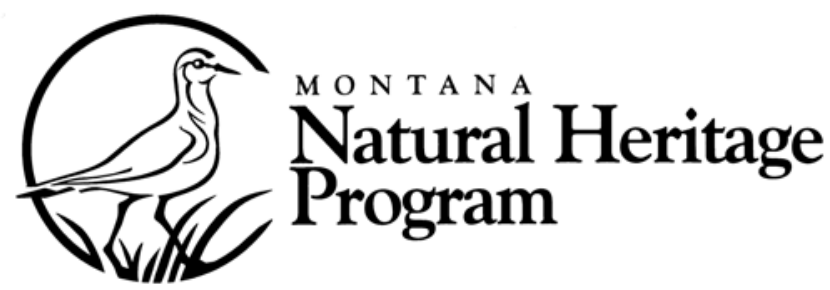




\title{
Plant Species of Concern and Plant Associations of \\ Powder River County, Montana
}

\author{
Prepared for the \\ Bureau of Land Management \\ Miles City, Montana \\ Under Agreement \# \\ 1422E930A960015 \\ by \\ Bonnie Heidel,Catherine Jean \\ and Susan Crispin \\ Montana Natural Heritage Program \\ 1515 East Sixth Avenue \\ Helena, Montana 59620-1800
}
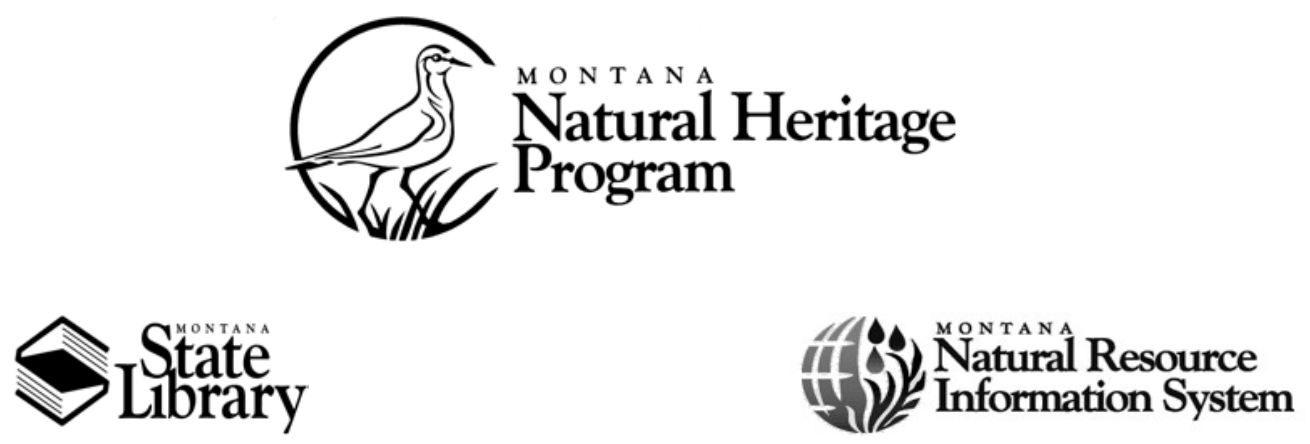

(C) 2002 Montana Natural Heritage Program

P.O. Box $201800 \bullet 1515$ East Sixth Ave • Helena, MT 59620-1800

This document should be cited as follows:

Heidel, B., C. Jean and S. Crispin. 2002. Plant Species of Concern and Plant Associations of Powder River County, Montana. Report to the Bureau of Land Management. Montana Natural Heritage Program, Helena, Montana. 23 pp. plus appendices. 


\section{EXECUTIVE SUMMARY}

Southeastern Montana, including Powder River County, has some of the most extensive range landscapes in the state. A long history of ranching as the predominant land use and effective land stewardship have maintained or restored extensive areas that support good quality rangelands with healthy, diverse populations of native wildlife and high ecological integrity. However, the biological character and richness of this region has not been well documented. The goal of this project was to survey Bureau of Land Management (BLM) lands in Powder River County for plant species of concern and document the natural vegetation on these lands, including communities of limited range and outstanding examples of more widespread community types.

Our survey work emphasized major blocks of land administered by the BLM, but also included other public lands near or continuous with BLM blocks. We visited most BLM tracts of at least five contiguous sections, as well as select scattered tracts, and adjacent private lands with landowner permission. We occasionally also surveyed on nearby state lands that were part of BLM allotments.

Surveys were conducted in the summers of 1999 and 2000. To document vegetation communities, we sampled a broad range of habitat types throughout the geographic breadth of BLM-administered lands in the county. Surveys ranged from the most rugged topography to flat lands and from the most heavily wooded to the least vegetated. We focused more detailed data collection on excellent representative areas of common vegetation types, those types of limited distribution and/or potential statewide or rangewide significance, and types not previously known or documented to occur in southeastern Montana. In surveying plant species of concern, we particularly emphasized species of global or range-wide significance.

All new data on plant species of concern and vegetation communities were geo-referenced, digitized and entered into the Montana Natural Heritage Program (MTNHP) data system, making them readily available to the BLM, as well as other landowners, resource managers and decision-makers, both public and private.

The results of these surveys doubled (from 5 to 10) the number of Montana plant species of concern documented in the County. Based on the number of new populations discovered, one species has been dropped from the Montana Species of Concern list, another is recommended for possible downgrading, and we recommend that four species be considered for removal from BLM "Watch" status.

We also documented a total of 46 native vegetation types in Powder River County. Several of these are particularly well-represented or of significance on BLM lands, either because of their extent and good condition and/or because they represent types that are uncommon or range-limited. In addition to collecting data from vegetation plots to better document and understand these communities, we also identified six notable areas where one or more were particularly well-represented in good or excellent condition, within ecologically intact landscapes.

While this study added a great deal to knowledge of the vegetation and ecology of Powder River County, it is far from comprehensive. We would recommend that inventory work be expanded to include fauna as well as flora, and to encompass lands under other ownerships to gain a more complete and accurate frame of reference for understanding the biological resources and ecology of this remarkably healthy and intact native landscape. 


\section{ACKNOWLEDGEMENTS}

For suggesting and initially facilitating this study, we are indebted to Hal Vosen, Range Conservationist now retired from the Bureau of Land Management (BLM), Miles City Office. We also received valuable support and assistance during the project from staff of the BLM Miles City Field Office, and from Bill Volk and Roxanne Falise of the Montana State Office.

A number of Heritage Program staff contributed to production of this report. Cedron Jones and Duane Lund designed and produced the maps; Martin Miller, Terrie Kenney, Joy Lewis, and Coburn Currier, helped with data processing and production, and Steve Cooper contributed to final editing.

This report has benefited from the support and contributions of many people, however any errors of commission or omission rest with the authors. This project was supported by a challenge cost-share agreement between the Bureau of Land Management and the Montana Natural Heritage Program (BLM Agreement Number 1422E930A960015, Task Orders \# 26 \& 31). 


\section{TABLE OF CONTENTS}

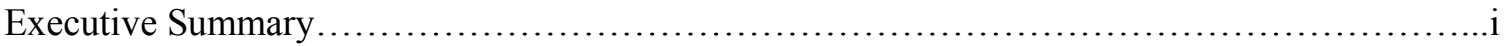

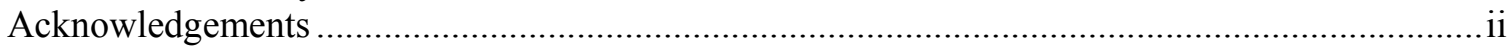

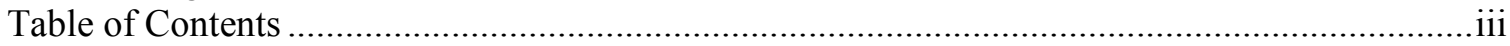

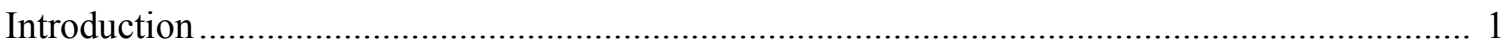

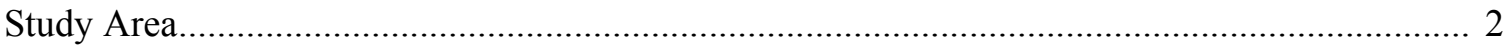

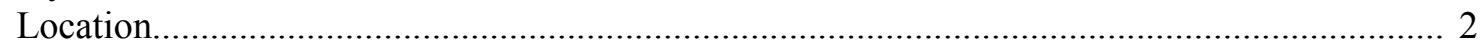

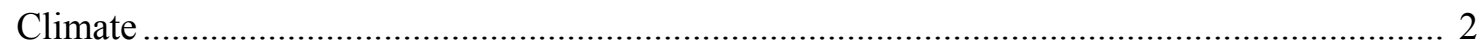

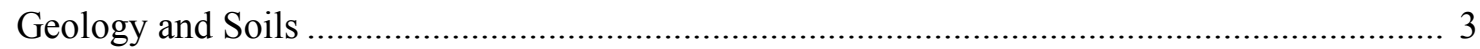

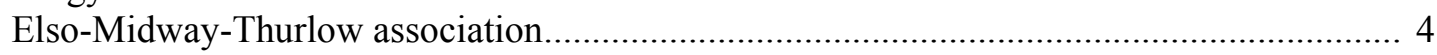

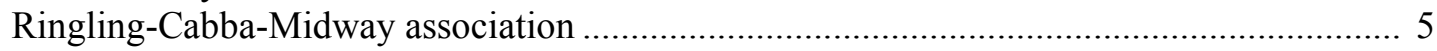

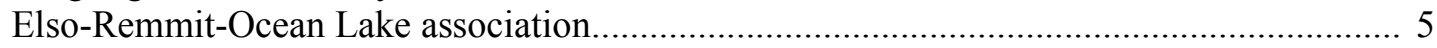

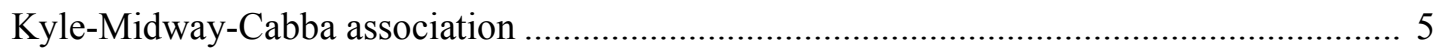

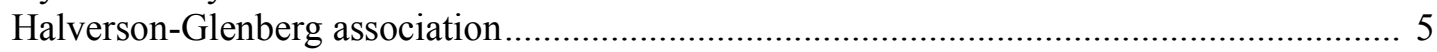

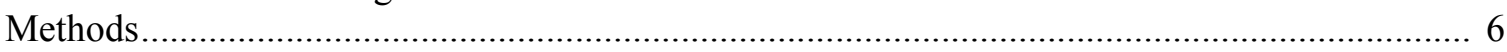

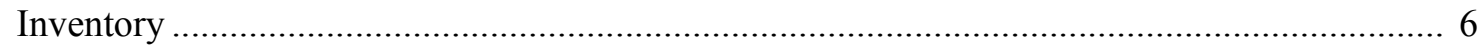

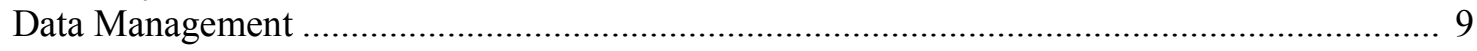

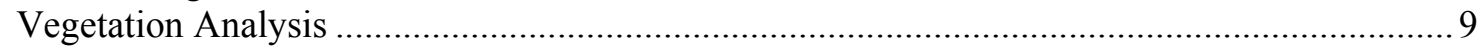

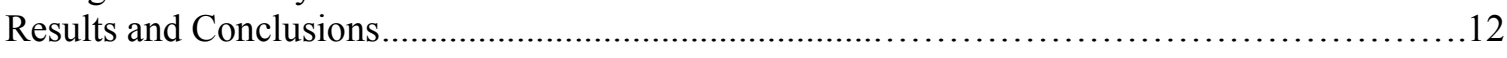

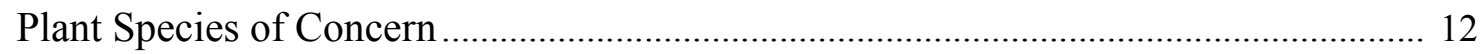

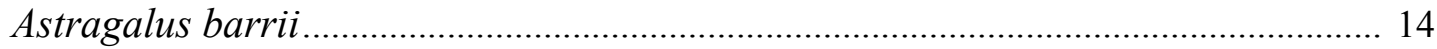

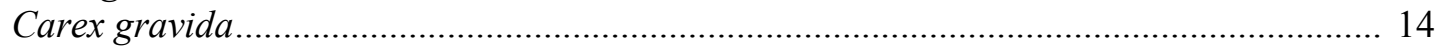

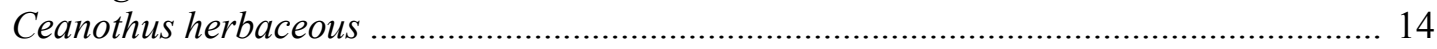

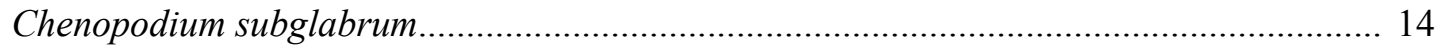

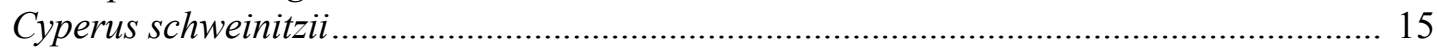

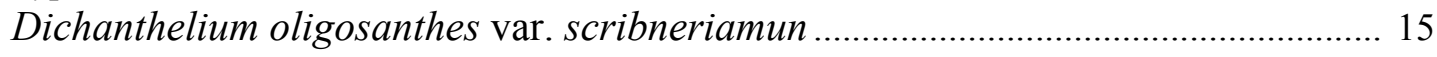

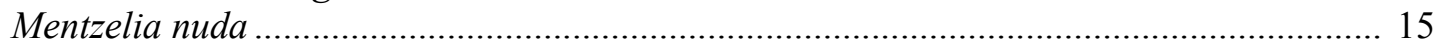

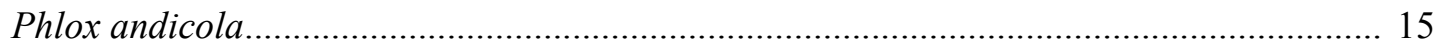

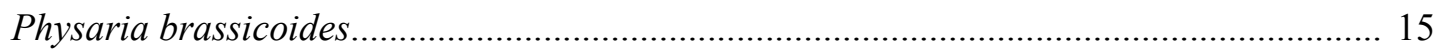

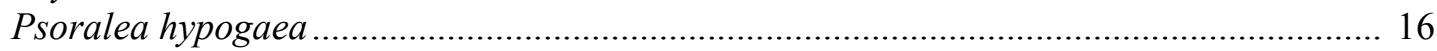

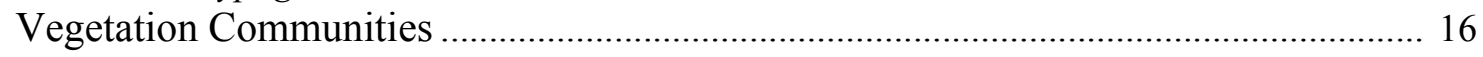

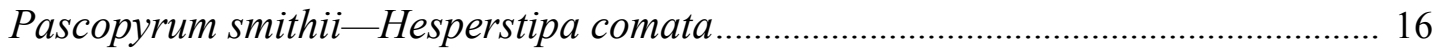

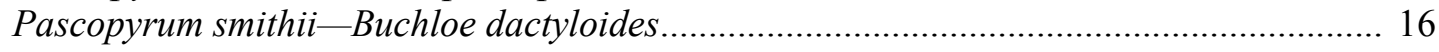

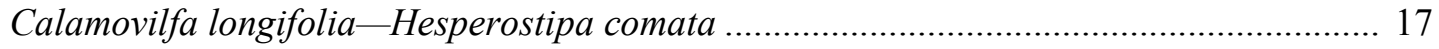

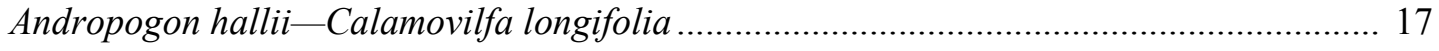

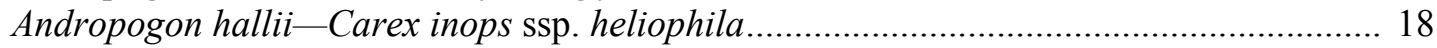

Pseudoroegneria spicata —Bouteloua curtipendula ........................................................ 18

Artemisia tridentata ssp. wyomingensis-Pascopyrum smithii ....................................... 18

Artemisia tridentata ssp. wyomingensis-Buchloe dactyloides .......................................... 19

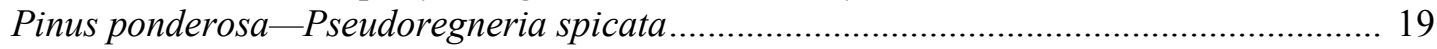

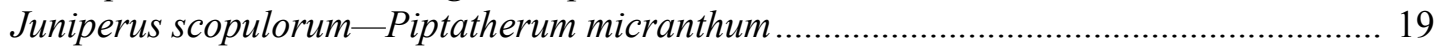

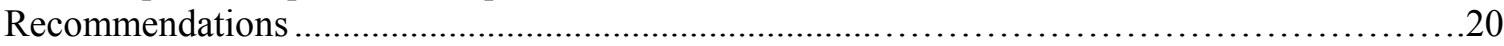

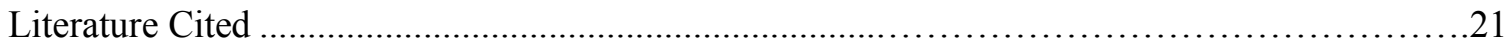




\section{FIGURES}

Figure 1. Topography of Powder River County

Figure 2. Powder River County Study Area

Figure 3. Climate Diagram of Broadus, MT

Figure 4. Elso-Midway-Thurlow association setting

Figure 5. Ringling-Cabba-Midway association setting

Figure 6. Elso-Remmit-Ocean Lake association setting

Figure 7. Kyle-Midway-Cabba association setting

Figure 8. Halverson-Glenberg association setting

Figure 9. Vegetation study plots in Powder River County

Figure 10. Plant species of concern in Powder River County

\section{TABLES}

Table 1. Plant Inventory Targets

Table 2. Plant Synonymy

Table 3. Plant Associations in Powder River County

Table 4. Plant Species of Concern in Powder River County

\section{APPENDICES}

Appendix A. Global/State Rank Definitions

Appendix B. Site Descriptions

Appendix C. Powder River County Plant Species of Concern

Appendix D. Rangeland ecological sites and plant associations of Powder River County

Appendix E. Plant Community Descriptions 


\section{INTRODUCTION}

Southeastern Montana, including Powder River County, has some of the most extensive range landscapes in the state. A long history of ranching as the predominant land use and effective land stewardship have maintained or restored extensive areas that support good quality rangelands with healthy, diverse populations of native wildlife and high ecological integrity.

However, the biological character and richness of this region has not been well documented. Recent studies focusing on the Tongue River drainage in southeastern Rosebud County (Heidel 1997) and

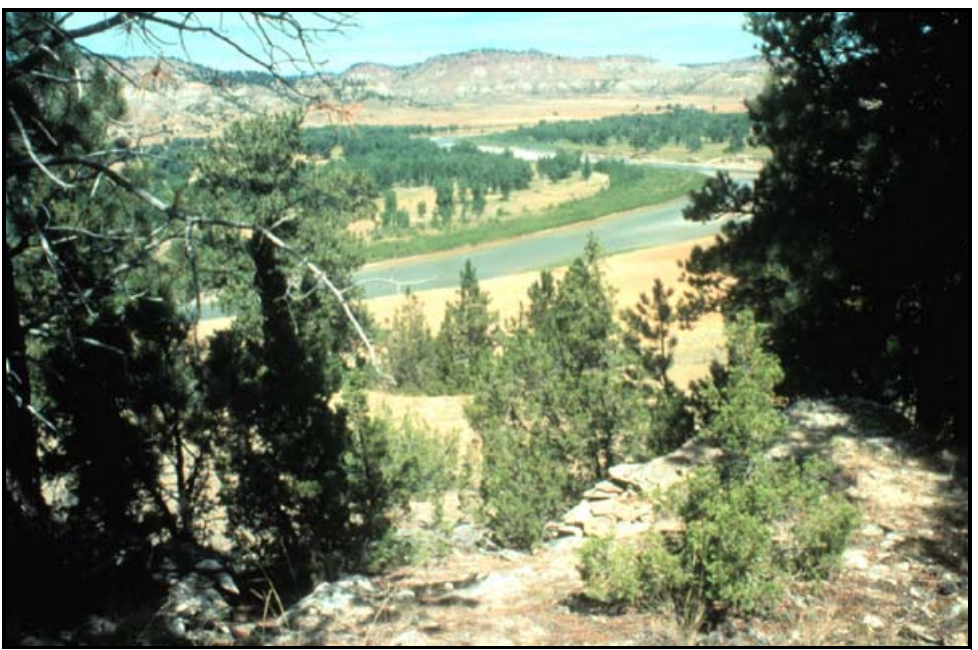

Photo by Bonnie Heidel Carter County (Vanderhorst et al. 1998) have provided a great deal of new information on the vegetation and rare flora, but neither extended to Powder River County. This study was undertaken as a first step in documenting the county's biological resources and ecology, in the context of southeastern Montana and the surrounding region.

Our goal was to survey BLM lands in Powder River County for plant species of concern and document the natural vegetation on these lands, including communities of limited range and outstanding examples of more widespread community types. Survey work emphasized major blocks of land administered by the Bureau of Land Management (BLM), but also included other public lands near or continuous with BLM blocks.

"Species of concern" are those identified by the Montana Natural Heritage Program (Heidel, 2001) as vulnerable to extirpation across their range or in Montana because of rarity, significant loss of habitat, and/or sensitivity to habitat disturbances. Most of these are also designated as BLM Special Status Species. We placed particular emphasis on species that are of global or rangewide concern (Heritage ranks G1 - G3; see Appendix A for rank definitions). In the course of survey work, we also documented locations for "species of potential concern" (formerly called "watch" species) - primarily species of uncertain status or regional endemics that are thought to be secure within their limited range.

Our specific objectives were to:

- Clarify the distribution and status of plant species and vegetation community types relative to BLM lands;

- Identify particularly significant populations, habitats and areas of natural vegetation on public lands in Powder River County;

- Highlight management opportunities for maintaining species of concern and significant vegetation communities;

- Consolidate new and previous information as a reference for the Bureau of Land Management and others. 


\section{STUDY AREA}

\section{LOCATION}

Powder River County covers 3,297 square miles of unglaciated Missouri Plateau in the Eastern Sedimentary Plains of southeast Montana. The Powder River and its tributaries, including Little Powder River, Mizpah Creek and Pumpkin Creek, drain most of the county, dissecting the uplands and underlying sedimentary bedrock layers. Otter Creek and Beaver Creek, tributaries of the Tongue River, drain the west end of the county. North-south valleys and intervening ridges form the prevalent landforms (Figure 1), spanning elevations from 2,768 feet in the county's northwest corner to 4,305 feet in the southwest corner (Parker et al. 1971).
Figure 1. Topography of Powder River County

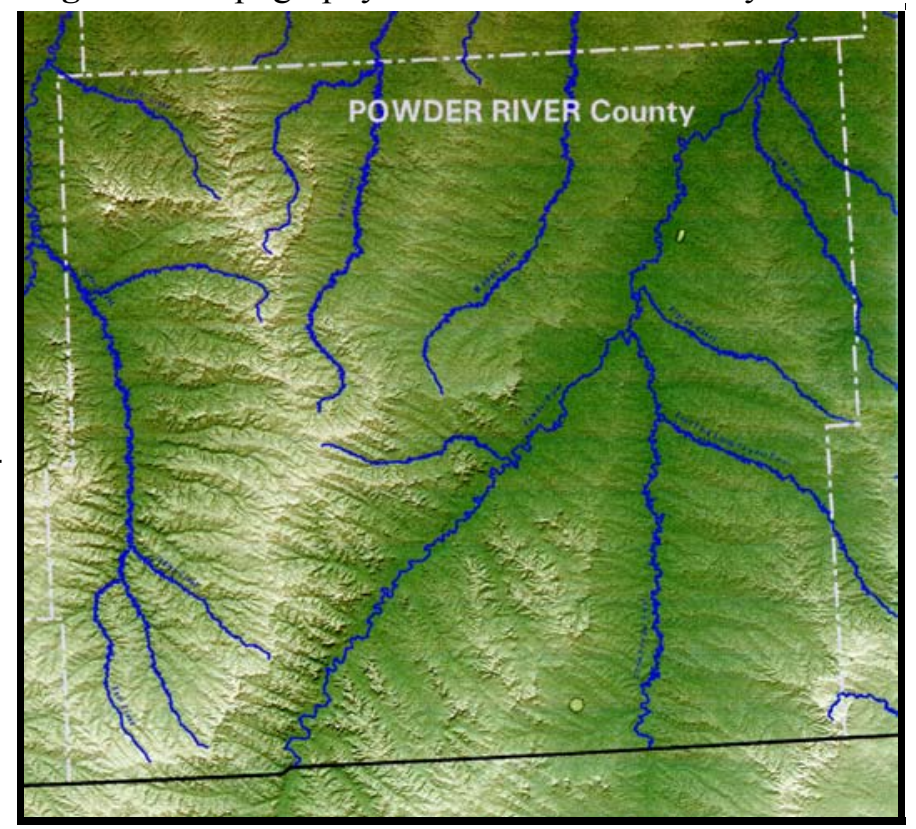

Powder River County was part of Custer County until 1919. The county seat, Broadus, lies at the junction of the county's two main highways, M-59 and US-212. Lands in the county were settled for ranching, and beef production reached its peak between 1880 - 1920 when open range prevailed (Parker et al. 1971). Cattle ranching remains the first and foremost industry the county today.

Like other counties in this area, the prevailing land cover is rangeland, however it includes a relatively high woodland component. In 1976, land cover in Powder River County was $84 \%$ rangeland, 10\% woodland, and 5\% cropland (Ross and Hunter 1976).

The highest ridge systems and the most extensive pine woodlands lie within the Ashland District of Custer National Forest at the western end of the County, though there are pine-covered escarpments and knolls in the southeastern corner and widely scattered throughout the County. Lands administered by the BLM are concentrated on, but not limited to, rough terrain along the Powder and Little Powder Rivers (Figure 2), and are intermingled with private and state lands.

\section{Climate}

The area's climate is continental and typical of the high plains, with cold winters, warm summers, and peak rainfall early in the growing season. Average annual precipitation at Broadus is 13.4 inches while across the county averages range from 11-19 inches. The average of mean monthly temperatures is $7.3^{\circ}$ Celsius $\left(45.1^{\circ}\right.$ Fahrenheit), with summer temperatures usually cooler than in the Yellowstone River valley to the north (Parker et al. 1971). Precipitation is typically concentrated in May and June, and maximum mean monthly temperatures occur later in July, resulting in a late summer water deficit (Figure 3). Compiled climate data invariably mask the high degree of variation in climate from year-to-year, monthto-month, and the great variations that occur even in the span of weeks, days and hours. 
Figure 2. Powder River County Study Area

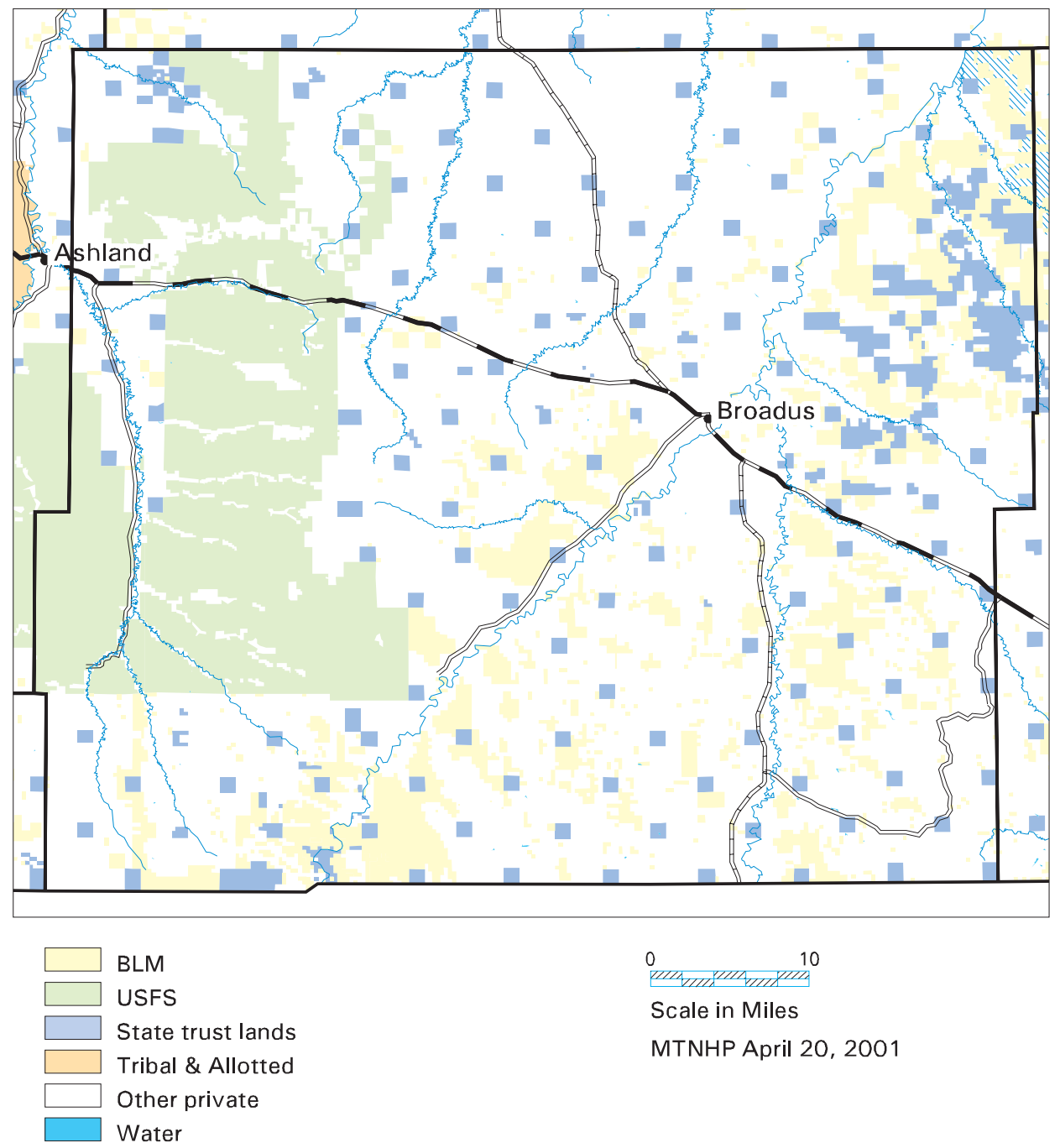

\section{GEOLOGY AND SOILS}

The sweeping, unglaciated landscape of Powder River County is carved by erosion largely from the Fort Union Formation, a heterogeneous Paleocene sedimentary deposit made up of sandstone, shale, bentonite, lignite and other materials. It is dissected by Quaternary alluvial deposits along major rivers and tributaries. The county lies entirely within the unglaciated segment of the Great Plains biogeographic province, and largely within the Powder River Basin section. Along the eastern side of the county, the Fort Union formation gives way to shales and claystones of the Pierre Shale Plains section.

Soils throughout the county are entisols and aridisols (Torriorthents and Camborthids) of dissected to nearly level sedimentary bedrock plains and hills. In addition, Ustorthents and Argiborolls occur in the pinelands, and Torrifluvents, Torriorthents and Camborthids in the broadest river valleys (Montagne et al. 1982). It is easiest to visualize the terrain and associated soils through schematic diagrams. The rela- 
Figure 3. Climate diagram showing average monthly temperature and precipitation for Broadus, MT. (Gray portion of bar indicates growing season length, or the number of frost-free days with mean daily minimum temperature above $0^{\circ}$ Centigrade.)

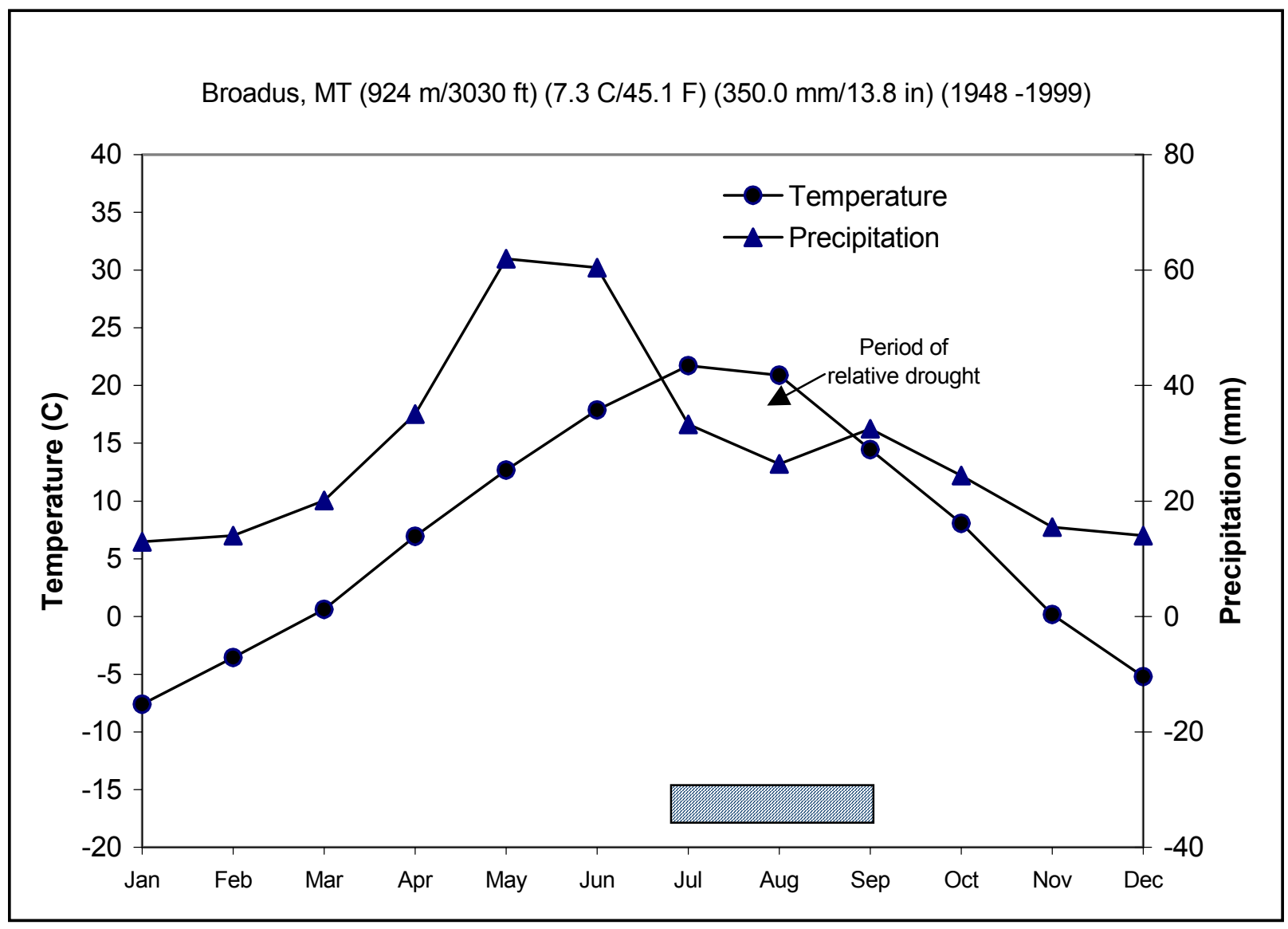

tionships between topography and soils for five of the nine major soil associations in the County are presented in Figures 4-8, from Parker et al. (1971). These were the primary associations in BLM lands that we surveyed, and are listed below in descending order of their prevalence on those lands.

\section{Elso-Midway-Thurlow association}

Dissected plains along the Powder and Little Powder Rivers are mainly calcareous silt loams and silty clay loams of the Elso-MidwayThurlow association (Figure 4). Deep-soil conditions are more extensive within the gentler 8$35 \%$ range of slopes, compared to the $35-75 \%$ range of slopes. This association comprises a disproportionately high share of BLM lands, about $28 \%$ of the county according to Parker et al. (1971). Silty ecological sites of the Elso series prevail in the dissected uplands, whereas the Midway series is associated with shallow clay and silt ecological sites on ridges and knolls. The bare Midway outcrops and gully erosion make it appear more dissected from the air (Figure 4) than it does from the ground.
Figure 4. Elso-Midway-Thurlow association setting

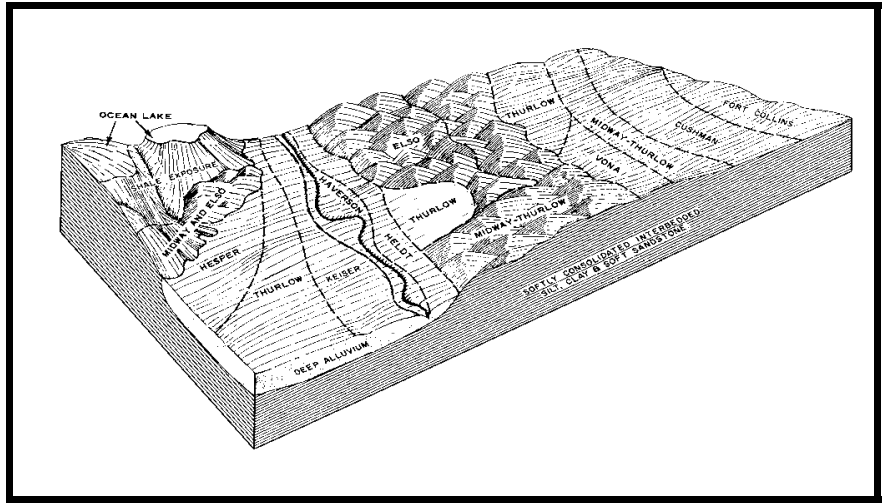


Ringling-Cabba-Midway association Irregularly sloping and hilly terrain at higher elevations in the county are made up of silty loams to clay loams (Figure 5). Ringling soils prevail and cap the uplands with erosionresistant baked porcellanite shale, representing a shallow ecological site. Cabba soils are medium-textured shallow soils. This association covers about $45 \%$ of the county according to Parker et al. (1971) and is distributed over much of the western half.
Figure 5. Ringling-Cabba-Midway association setting

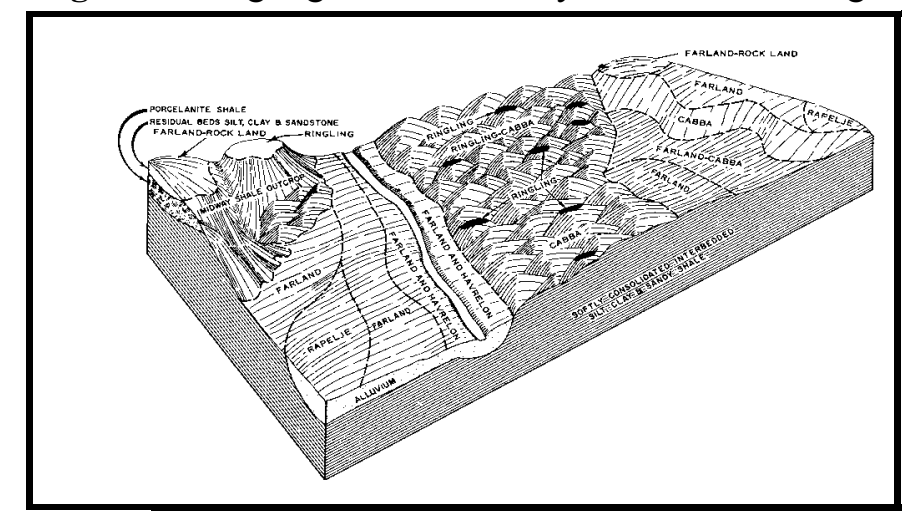

Figure 6. Elso-Remmit-Ocean Lake association setting

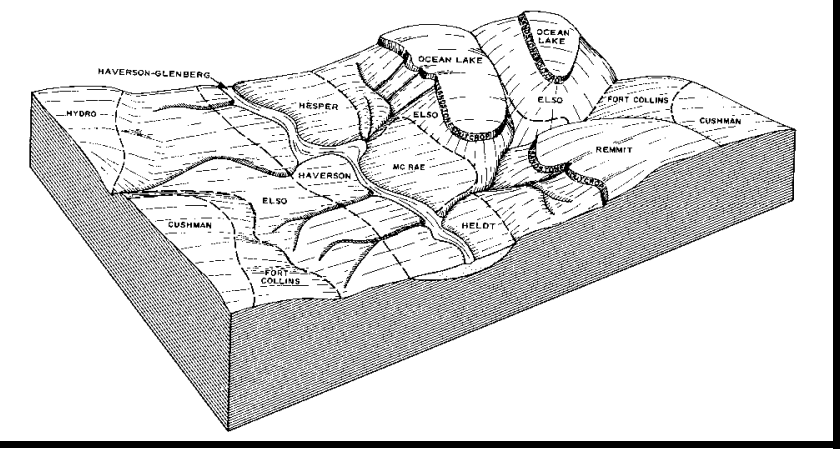

Elso-Remmit-Ocean Lake association Smooth, rounded hills and sparingly dissected plains are made up of sandy loams and shallow silt loams at the far eastern end of the county (Figure 6). Silty ecological sites of the Elso association prevail in parts of the gentle uplands, while sandy ecological sites of the Remmit and Ocean Lake series are also throughout the uplands.

\section{Kyle-Midway-Cabba association}

Hilly, rounded relief in the far southwestern corner of the county has deep soils that are clayey throughout (Figure 7). This association resembles the Ringling-Cabba-Midway association (preceding) except for the prevalence of the Kyle series, resulting in more rolling than dissected terrain.
Figure 7. Kyle-Midway-Cabba association setting

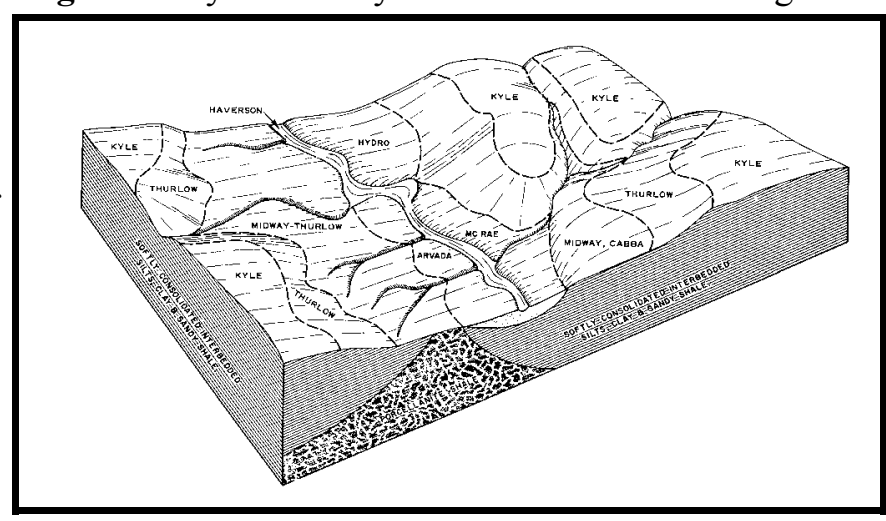

Figure 8. Halverson-Glenberg association setting

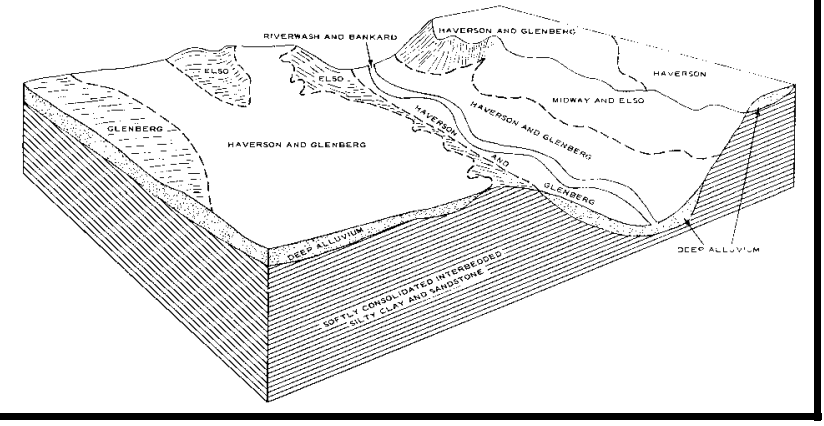

\section{Halverson-Glenberg association}

Valley bottoms and stream terraces have deep loams soils derived from alluvium (Figure 8). These low-lying areas and their gentle terrain are found along all of the rivers as well as most of the major creeks, (those labeled on the BLM 1:100,000 map series). 


\section{METHODS}

Surveys were conducted in the summers of 1999 and 2000. During the first year of fieldwork, we focused on targeted surveys for species of concern (Table 1) and priority vegetation types. During 2000, we more thoroughly documented plant associations in the largest blocks of BLM-administered lands.

We began by compiling and reviewing existing data on species of concern and vegetation for Powder River County, as well as adjacent counties and states. This information was used to target areas of potential habitat for species of concern and to identify the range of native vegetation types documented.

Information sources for vegetation and flora included Taylor and Holst (1976), Culwell (1979), Husby et al. (1979), Hansen and Hoffman (1988) and Vanderhorst et al. (1998), in addition to unpublished working lists of plant associations for the region, and data assembled and rapid ecological assessments conducted for The Nature Conservancy's Northern Great Plains Steppe Ecoregion Plan (The Nature Conservancy 1999). The two studies on the Ashland District of Custer National Forest (Taylor and Holst 1976, Hansen and Hoffman 1988) were the only readily available references on the county's vegetation. In addition to these reports, we drew on vegetation information from studies in adjoining states and provinces, and from the recently compiled state and regional National Vegetation Classification System (NVCS) for Great Plains states (NatureServe 2002, Faber-Langendoen 1999).

Other useful information sources included the Powder River County Area soils survey (Parker et al. 1971), a Natural Resource Conservation Service (NRCS) field review of mapping units (1980). We also consulted BLM color aerial photographs to assess characteristics of BLM tracts and to help identify areas of potential habitat for target species. Notes were transcribed onto U.S.G.S. topographic maps (7.5') for reference in the field.

From the MTNHP databases, we identified plant species of concern with documented occurrences in the county and compiled available information on their biology and habitat characteristics. Some occurrences were targeted for re-visits to fill data gaps on the extent of populations, exact locations, or habitat. We also drew on findings from previous botanical surveys in the region (Heidel and Dueholm 1995, Heidel and Marriott 1996, Vanderhorst et al. 1998) to identify species of concern that may potentially occur in Powder River County. Based on this information, we developed an expanded list of target species for our inventories (Table 1).

\section{FIELD SURVEYS}

Surveys were focused on the largest blocks of BLM-administered lands. We visited most BLM tracts of at least five contiguous sections, as well as select scattered tracts, and adjacent private lands with landowner permission. We occasionally also surveyed on nearby state lands that were part of BLM allotments.

We documented occurrences for species of concern by collecting observational data on biology, habitat, population size and possible trends. Locations of rare plants were mapped on 7.5 ' topographic quads.

Vouchers specimens were collected if population numbers were sufficiently large to avoid impact (Montana Native Plant Society 1993). We also kept a running list of the species encountered, crossreferencing this with county dot maps in two floristic references (Booth and Wright 1966, Great Plains Flora Association 1977), and with the general distributions described in Dorn's flora of Montana (1984), and flora of Wyoming (Dorn 1992), the distribution data in the Wyoming Rare Plant Field Guide (Fertig et al. 1994) and the Wyoming plant distribution atlas (http://www.esb.utexas.edu/tchumley/wyomap/ atlas.htm). 
Table 1. Inventory Targets for Plant Species of Concern

\begin{tabular}{|c|c|c|c|c|}
\hline Scientific Name & \multicolumn{4}{|c|}{ Global State } \\
\hline \multicolumn{5}{|l|}{ Species of Concern } \\
\hline Amorpha canescens & Leadplant & G5 & $\mathrm{SH}$ & July \\
\hline Asclepias stenophylla & Narrowleaf milkweed & G4G5 & S1 & late June-July \\
\hline Astragalus barri & Barr's milkvetch & G3 & $\mathrm{S} 3$ & May-early June \\
\hline Astragalus racemosus var. racemosus & Raceme milkvetch & G5T5 & $\mathrm{S} 2$ & July \\
\hline Carex gravida var. gravida & Pregnant sedge & G5T5? & $\mathrm{S} 1$ & late June-July \\
\hline Ceanothus herbaceous & New Jersey tea & G5 & $\mathrm{SH}$ & late June \\
\hline Chenopodium subglabrum & Smooth goosefoot & G3G4 & S1 & July \\
\hline Cyperus acuminatus & Short-pointed flatsedge & G5 & $\mathrm{S} 1$ & July-Aug \\
\hline Dichanthelium oligosanthes var. scribnerianum & Scribner's panic grass & G5T5 & $\mathrm{S} 1$ & late June-July \\
\hline Eriogonum visheri & Visher's buckwheat & G3 & S1 & July \\
\hline Mentzelia nuda & Dwarf mentzelia & G5 & $\mathrm{S} 1$ & July \\
\hline Phlox andicola & Plains phlox & G4 & $\mathrm{S} 2$ & May-June \\
\hline Physaria brassicoides & Double bladderpod & G5 & $\mathrm{S} 2$ & May-June \\
\hline Physaria didymocarpa var. lanata & Woolly bladderpod & G5T2 & $\mathrm{S} 1$ & \\
\hline Psilocarphus brevissimus var. brevissimus & Dwarf wooly-heads & G5T? & $\mathrm{S} 2$ & late June-July \\
\hline Scirpus heterochaetus & Slender bulrush & G5 & S1 & July \\
\hline Sporobolus asper & Longleaf dropseed & G5 & $\mathrm{SH}$ & July \\
\hline \multicolumn{5}{|l|}{ Species of Potential Concern } \\
\hline Agastache foeniculum & Lavender hyssop & G5? & SA? & July \\
\hline Carex torreyi & Torrey's sedge & G4 & S3 & July \\
\hline Echinacea angustifolia & Purple coneflower & G4 & SU & June-July \\
\hline Evax prolifera & Big-head evax & G5 & SU & June \\
\hline Geum canadense & White avens & G5 & SU & June \\
\hline Ipomopsis congesta ssp. pseudotypica & Wyoming ipomopsis & G5T3? & $\mathrm{S} 2 \mathrm{~S} 3$ & May-June \\
\hline Psoralea hypogaea & Little indian breadroot & G5T4 & S2S3 & May-June \\
\hline
\end{tabular}

During the first year of vegetation surveys, we sampled a broad range of habitat types throughout the geographic breadth of BLM-administered lands in the county. Surveys ranged from the most rugged topography to flat lands and from the most heavily wooded to the least vegetated. Survey results were compared against documented Montana plant associations to identify uncommon or previously undocumented types.

Based on results from the first year of surveys, we designed vegetation surveys in 2000 to characterize:

1. Excellent representative areas of common plant associations,

2. Plant associations of potential statewide or rangewide rarity and significance, and

3. Provisional new plant associations or those not previously known from southeastern Montana. 
We could not sample all plant associations in each area surveyed, but rather focused on the more distinctive types and those meeting the criteria listed above. This approach made it possible to collect a broader range of information relatively quickly, while focusing more detailed data collection on the more important or distinctive vegetation features in the study area.

Plant associations were identified and documented based on species composition, structure and abiotic environmental characteristics. Vegetation data was collected within representative $1 / 10$ acre plots (37.2 $\mathrm{ft}$ radius) and recorded on a standardized survey form. Vegetation plots were placed to sample homogeneous natural vegetation and uniform environmental conditions across the plot, in areas of least disturbance (Figure 9). Soil texture was recorded and used to characterize the ecological site. All species present were recorded with canopy cover values.

Our surveys focused on grassland types for several reasons. Grasslands represent well over $90 \%$ of the existing natural vegetation on BLM lands, and are among the most distinguishing ecological features of the county, in a statewide context. In addition, grasslands of this area provide a missing link in piecing together vegetation classifications of adjoining areas.

Figure 9. Vegetation sampling plots in Powder River County

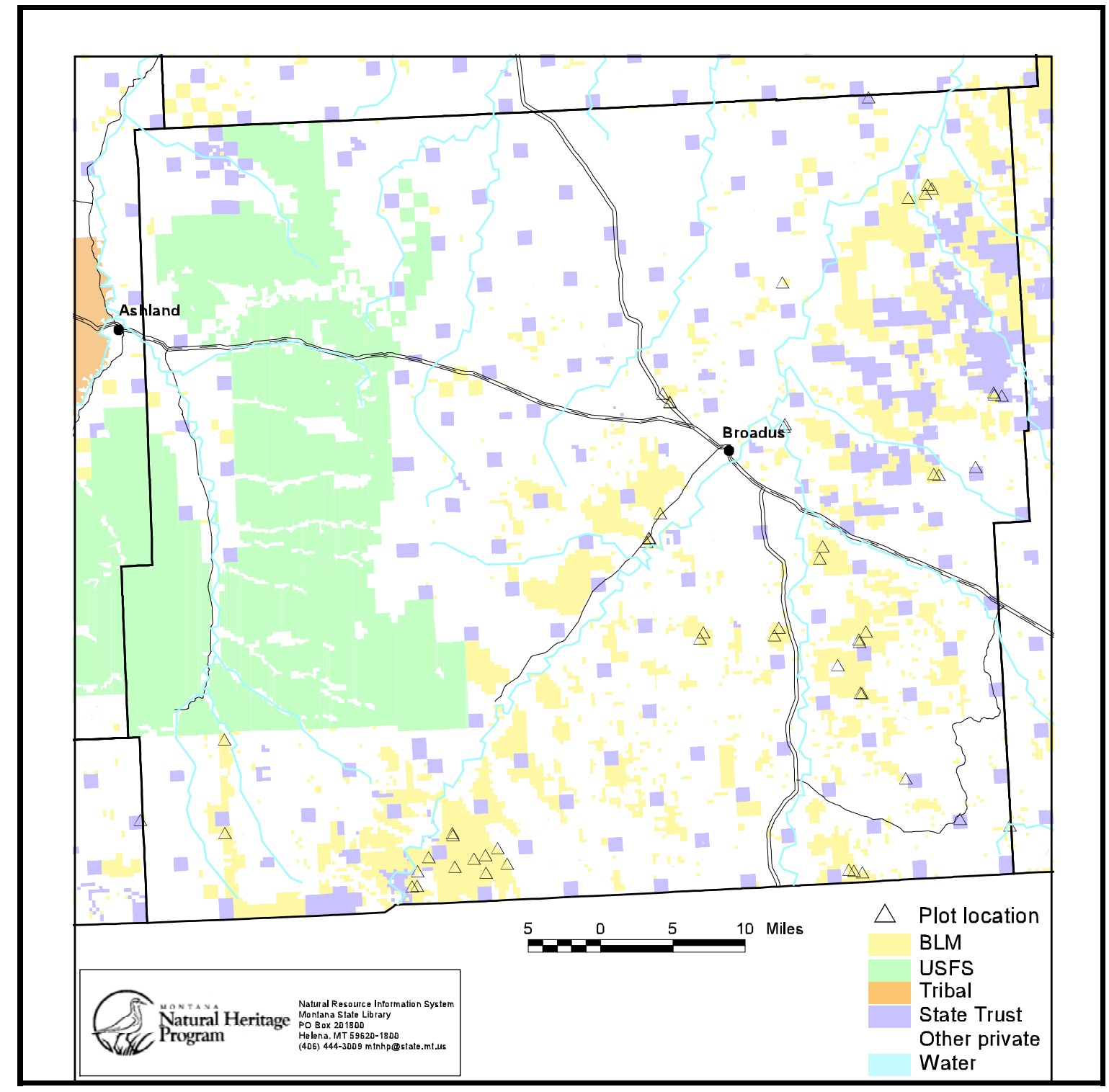


Our principle floristic references were the Great Plains Flora (1977, 1986), Dorn (1984), and Hitchcock and Cronquist (1973). Plant nomenclature follows Kartesz (1999), which uses newly revised names for the wheat-grass tribe (Elymus and Agropyron), replacing the more familiar scientific names that have long been in general use. Thus western wheatgrass, which is referenced as Agropyron smithii in Booth (1950) and Hitchcock and Cronquist (1973) and Elymus smithii in Dorn (1984), is now treated as as Pascopyrum smithii. Table 2 provides a cross-reference for synonymy of dominant and indicator species that appear in our plant association names. We also reference each species by both scientific and common name when first mentioned in this report. Common names are based primarily on a national list developed by the Natural Resource Conservation Service (2001). To a lesser degree, we use common names cited by Region 1 of the U. S. Forest Service.

\section{Data Management}

New data collected on plant species of concern and high quality vegetation communities were georeferenced, digitized and documented as element occurrence records in the data system of the Montana Natural Heritage Program. Specimens have been deposited at the University of Montana (MONTU). Plot data and summary information on noteworthy sites were also transcribed to a computerized format for permanent storage in the MTNHP databases. This data system serves as the state's clearinghouse and as a primary source of information on the status and distribution of Montana's native species and habitats.

\section{VEGETATION ANALYSIS}

We analyzed vegetation data to identify plant associations consistent with the National Vegetation Classification System (Grossman et al. 1998). This classification uses recurring vegetation attributes, emphasizes natural existing conditions, and can be used to identify vegetation units based on both quantitative and, in some cases, qualitative data. The NVCS is hierarchical and combines floristics at the lowest levels (associations and alliances) and structure (physiognomy) and overarching climate conditions at the highest levels. Plant associations are defined by dominant species of the uppermost vegetation layer and any co-dominant species, diagnostic species, or the dominant species of understory vegetation layers.

We developed a preliminary cross-reference (see Appendix D) between NRCS rangeland ecological sites and plant associations tracked by the Montana Natural Heritage Program. Some plant associations have wide ecological amplitude and occur across a range of ecological sites. For example, Artemisia tridentata spp. wyomingensis / Pascopyrum smithii can be found on thin silty, very shallow to clayey ecological sites, whereas Atriplex confertifolia - Artemisia tridentata is found only on the shale ecological site. 
Table 2. Synonymy of scientific names for indicator and characteristic plant species (alphabetically arranged in $2^{\text {nd }}$ column).

\begin{tabular}{|c|c|c|c|}
\hline Common Name & $\begin{array}{c}\text { In: Booth (1950), (1966) or } \\
\text { Great Plains Flora Assoc. } \\
(1986)\end{array}$ & In: Dorn (1984) & $\begin{array}{c}\text { In: Kartesz \& Meacham } \\
(1999)\end{array}$ \\
\hline Thickspike Wheatgrass & Agropyron dasystachyum & Elymus lanceolatus & Elymus lanceolatus \\
\hline Bearded Wheatgrass & Agropyron caninum & Elymus trachycaulus & Elymus trachycaulus \\
\hline $\begin{array}{l}\text { Intermediate Wheat- } \\
\text { grass }\end{array}$ & Agropyron intermedium & Elymus hispidus & Thinopyrum intermedium \\
\hline Western Wheatgrass & Agropyron smithii & Elymus smithii & Pascopyrum smithii \\
\hline Bluebunch Wheatgrass & Agropyron spicatum & Elymus spicatus & Pseudoroegneria spicata \\
\hline Redtop & Agrostis stolonifera & Agrostis stolonifera & Agrostis gigantea \\
\hline Creeping Bentgrass & Agrostis alba var. Agrostis & Agrostis stolonifera & Agrostis stolonifera \\
\hline Little Bluestem & Andropogon scoparius & Schizachyrium scoparium & Schizachyrium scoparium \\
\hline Gardneri's Saltsage & Atriplex nuttallii & Atriplex gardneri & Atriplex gardneri \\
\hline Rillscale & Atriplex dioica & Atriplex suckleyi & Endolepis dioica \\
\hline Needleleaf Sedge & Carex eleocharis & Carex stenophylla & Carex duriuscula \\
\hline Sun Sedge & Carex heliophila & Carex pensylvanica & Carex inops ssp. heliophila \\
\hline Woolly Sedge & Carex lanuginosa & Carex lanuginosa & Carex pellita \\
\hline Rubber Rabbitbrush & Chrysothamnus nauseosus & Chrysothamnus nauseosus & Ericameria nauseosa \\
\hline Tufted Hairgrass & Deschampsia cespitosa & Deschampsia cespitosa & Deschampsia cespitosa \\
\hline Inland Saltgrass & Distichlis spicata var. stricta & Distichlis stricta & Distichlis spicata \\
\hline Few-headed Spikerush & Eleocharis pauciflora & Eleocharis pauciflora & Eleocharis quinueflora \\
\hline Giant Wildrye & Elymus cinereus & Elymus cinereus & Elymus cinereus \\
\hline Prairie Junegrass & Koeleria pyramidata & Koeleria macrantha & Koeleria macrantha \\
\hline Indian Rice grass & Oryzopsis hymenoides & Oryzopsis hymenoides & Achnatherum hymenoides \\
\hline Littleseed Ricegrass & Oryzopsis micrantha & Oryzopsis micrantha & Piptatherum micranthum \\
\hline Sandberg Bluegrass & Poa sandbergii & Poa secunda & Poa secunda \\
\hline Black Cottonwood & $\mathrm{n} / \mathrm{a}$ & Populus balsamifera & $\begin{array}{l}\text { Populus balsamifera ssp. } \\
\text { trichocarpa }\end{array}$ \\
\hline Shrubby Cinquefoil & Potentilla fruticosa & Potentilla fruticosa & $\begin{array}{l}\text { Dasiphora fruticosa ssp. } \\
\text { floribunda }\end{array}$ \\
\hline Silver-leaved Scurfpea & Psoralea incana & Psoralea argophylla & Pediomelum argophyllum \\
\hline Lemon Scurfpea & Psoralea lanceolata & Psoralea lanceolata & Psoralidium lanceolatum \\
\hline Hardstem Bulrush & Scirpus acutus & Scirpus acutus & Schoenoplectus acutus \\
\hline Needle-and-thread & Stipa comata & Stipa comata & Hesperostipa comata \\
\hline $\begin{array}{l}\text { Northern Porcupine } \\
\text { Grass }\end{array}$ & Stipa c & $\begin{array}{l}\text { Stipa spartea (implicit as } S . s \text {. } \\
\text { var. curtiseta) }\end{array}$ & curtiseta \\
\hline Green Needlegrass & Stipa viridula & Stipa viridula & Nassella viridula \\
\hline
\end{tabular}




\section{RESULTS AND CONCLUSIONS}

Among the most ecologically significant characteristics of BLM lands in Powder River County are the extensive and largely intact range landscapes, especially those supporting a mosaic of western wheatgrass and Wyoming big sagebrush vegetation. Both grassland and sagebrush communities support diverse suites of native species, some of which have been identified as potentially declining or vulnerable either locally or regionally. Fortunately, all or nearly all of these species still thrive in the large, ecologically intact range landscapes that exist in Powder River County and elsewhere in eastern Montana. Although this survey did not focus on animal species, it did yield substantial new information on plant species of concern, the diversity of vegetation types in the county, and areas supporting particularly significant species populations and/or vegetation communities.

Other features of ecological significance in the county are the extensive sandy ecological sites, which appear as isolated but not uncommon areas of well-developed sandy habitat. These sites support many plant species of limited regional distribution or endemism that are Montana species of concern, and they also support distinctive plant communities.

\section{Plant SPecies of Concern}

Our surveys identified 5 new species of concern in the county, bringing the total documented to 10 (listed in Table 3). All but one are designated as BLM "Watch" species. Our surveys also generated new locations for species of concern that were previously documented in the county. Perhaps the most important findings were new locations for Astragalus barrii (Barr's milkvetch), expanding the total known in the county to 23, including the largest population documented to date in Montana (see below). Figure 10 shows all known locations for species of concern in the county.

Table 3. Plant species of concern in Powder River County.

\begin{tabular}{|c|c|c|c|c|c|}
\hline Scientific Name & Common Name & $\begin{array}{c}\text { Global/ } \\
\text { State Rank }\end{array}$ & BLM Status & $\begin{array}{c}\text { Records in } \\
\text { Powder } \\
\text { River Co. }\end{array}$ & $\begin{array}{c}\text { Records in } \\
\text { Montana } \\
\text { (total) }\end{array}$ \\
\hline Astragalus barrii & Barr's Milkvetch & $\mathrm{G} 3$ / S3 & Watch & 23 & 32 \\
\hline Carex gravida var gravida & Pregnant Sedge & G5T5 / S1 & Watch & 1 & 5 \\
\hline Ceanothus herbaceus & New Jersey Tea & G5T? / SH & Watch & 1 & 1 \\
\hline Chenopodium subglabrum & Smooth Goosefoot & G3G4 / S1 & Watch & 1 & 5 \\
\hline Cyperus schweinitzii & Schweinitz' Flatsedge & G5 / S2 & Watch & 2 & 8 \\
\hline $\begin{array}{l}\text { Dichanthelium oligosanthes } \\
\text { var scribnerianum }\end{array}$ & sScribner's Panic Grass & G5T5 / S1 & Watch & 4 & 6 \\
\hline Mentzelia nuda & Bractless Mentzelia & G5 / S1 & Watch & 3 & 8 \\
\hline Phlox andicola & Plains Phlox & G4 / S2 & Watch & 1 & 10 \\
\hline Physaria brassicoides & Double Bladderpod & G5 / S2 & & 3 & 8 \\
\hline Psoralea hypogaea & \multicolumn{3}{|c|}{ Little Indian BreadfruitG5T4 / S2S3 Watch } & 6 & 18 \\
\hline
\end{tabular}


Figure 10. Locations for Plant Species of Concern in Powder River County

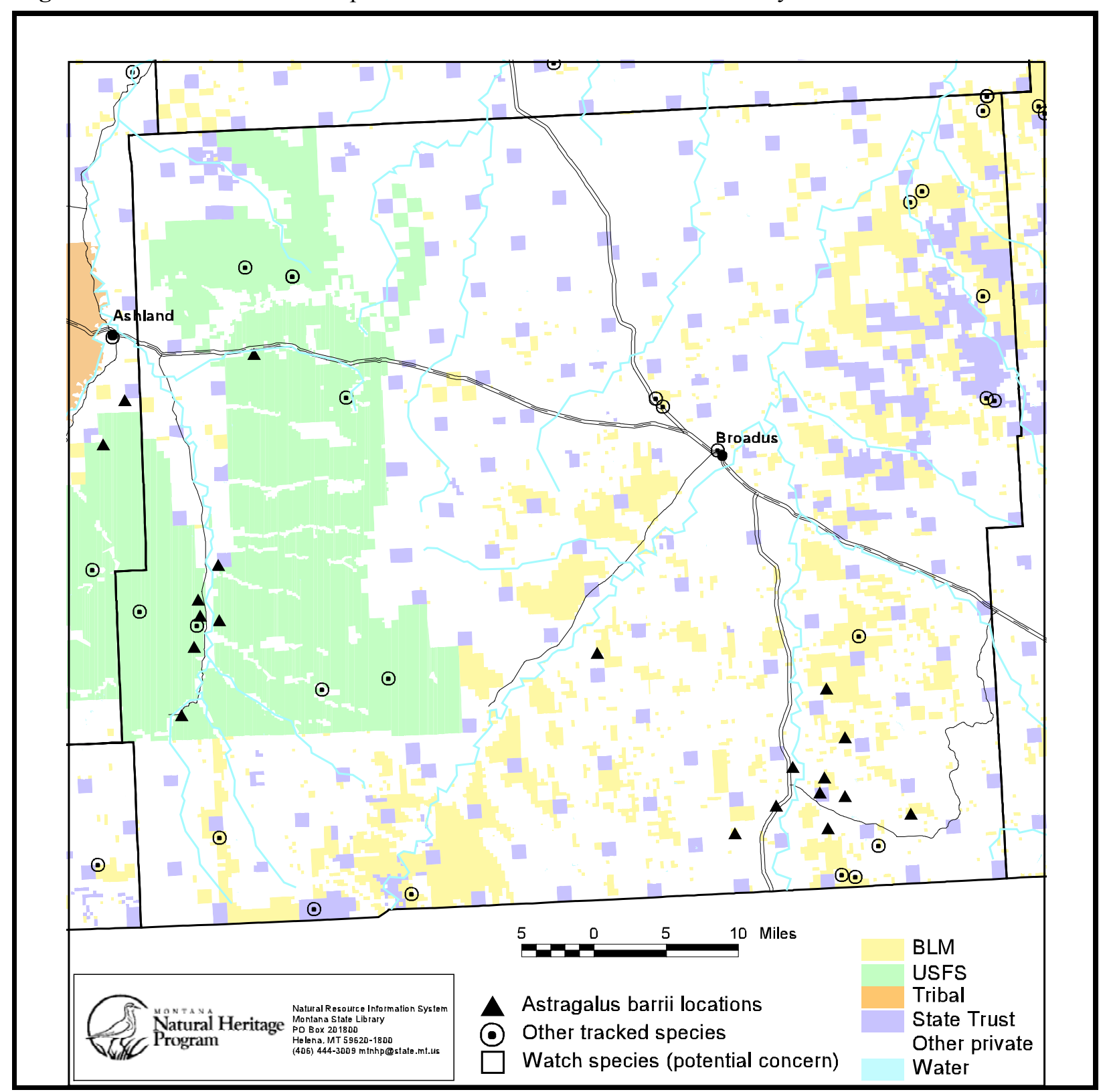

Information gathered during survey work has also provided new insights into the habitats characteristics and ecology of these species. Below, we have summarized current information for each species on their distribution in the county and potential management considerations. Appendix C provides full species descriptions with additional information, including detailed identification and habitat data, range-wide distribution, an explanation of status, and illustrations and photos of each species.

Astragalus barrii, Barr's milkvetch (G3, S3, BLM Watch status)

County Distribution: The two largest areas of concentration for this species in Montana lie in Powder River County, where it has been documented from a total of 23 locations. Of those, 18 are clustered into two large population complexes, one along part of Otter Creek and the other in the Little Powder Riverdrainage. In visits to the latter, we found that it occurs repeatedly across the landscape where suitablehabitat is extensive, such that some of the populations are quite large. 
Ecology and management considerations: This species almost always occurs on secondary range and is not grazed due to its low growth form. It is little-affected by allotment management practices and developments unless concentrated livestock trampling occurs in its habitat. It may be vulnerable to exotic species encroachment, however there is little threat from weedy annuals at present, and the fine texture and instability of soils limit invasion by annual bromes. A non-native mustard, Malcolmia (Malcolmia africana), is beginning to invade fine-textured slopes of Powder River County; it has become abundant in similar habitats elsewhere, and appears to be spreading along backroads. Seeding of sweetclover (Melilotus spp.) should be avoided in revegetation efforts or road plantings near this species' habitat.

Status Note: Barr's milkvetch is a regional endemic species of limited distribution in the northern Great Plains, where it is restricted to portions of three states. Its total range comprises an area less than half the size of Montana. Given the extensive distribution of Barr's milkvetch in Powder River County, the status of this species will be reviewed and may be downgraded statewide from "species of concern" to "species of potential concern." This evaluation will need to consider any current threats to the species and the security of existing populations and habitats with respect to land management, especially for those on public lands.

Carex gravida, Pregnant Sedge (G5, S1)

County Distribution: It has only been found in two places on the Ashland District of the Custer National Forest (Heidel and Marriott 1996), and these represent the known Powder River and Rosebud records. In the course of this survey there was very little suitable habitat in the areas that were visited, so it was not found and no additional data was collected on this species and its distribution.

Ecology and management considerations: This plant seems restricted to mesic microhabitats within pine woodlands, which could make it vulnerable to changes in woodland structure and composition by grazing and logging. These settings are also vulnerable to invasion of exotic species like Kentucky bluegrass (Poa pratensis). There were fire scars among the Ponderosa pine at one of the Ashland District sites where it occurred, indicating that the species survives ground fires.

Status note: Since this species is restricted to woodlands and has not been found on BLM lands in Montana, it could be dropped from BLM "Watch" status.

Ceanothus herbaceous, New Jersey tea (G5, SH)

County Distribution: The single collection of this species in Montana was from a "grassy, pine-covered hill" in Powder River County. There are few pine stands on BLM lands in the county, and of the few that were surveyed, none appeared to have suitable microhabitat. It is not known whether this species is restricted to pineland habitat in Montana, and we also looked for it nearby grassland habitat on BLM lands. We did not locate it, and were unable to collect any additional data on this species in the county.

Ecology and management considerations: We have no information on the ecology of this plant. It has reportedly diminished elsewhere on the Great Plains (Ode, pers. comm.) Some species of Ceanothus are highly palatable to wildlife and livestock.

Status note: Since this species is restricted to woodlands and has not been found on BLM lands in Montana, it could be dropped from BLM "Watch" status.

Chenopodium subglabrum, Smooth Goosefoot (G3G4, S1)

County Distribution: This plant was documented for the first time in Powder River County and on BLM-administered lands during this study. We found it in the northeastern corner of the County on an isolated ridgetop. 
Ecology and management considerations: The Powder River County population occurs in secondary range, where livestock use is light and water sources are remote. This species is a poor competitor and is associated with other annuals and early-succession species. Maintenance of early successional habitat in upland settings requires a balance of fire and/or grazing. Leafy spurge is in early stages of invading some of the most extensive areas of this habitat type in the state.

Cyperus schweinitzii, Schweinitz' Flatsedge (G5, S2)

County Distribution: We documented this plant for the first time in Powder River County, at two sites in the northeastern corner in small blowouts at toeslope positions on loose sand eroded from sandstone outcrops above.

Ecology and management considerations: The Powder River populations occur in primary range that is in good to excellent condition. Maintaining the species' early-succession habitat requires grazing and/or fire, and it may decline in the absence (or excess) of these. Leafy spurge is in early stages of invading some of the most extensive areas of this habitat type in the state.

Dichanthelium oligosanthes var. scribnerianum, Scribner's Panic Grass (G5T5, S1) County Distribution: This plant has been documented at four sites in Powder River County, all on the Ashland District of Custer National Forest. It grows in open ponderosa pine woodlands of valleys and plains. There are few pine stands on BLM lands in the county, and of the few that were surveyed, none appeared to have suitable microhabitat.

Ecology and management considerations: This species occupies open pine woodland that may be affected by vegetation encroachment and by grazing, particularly early in the growing season. It cannot complete with sod-forming grasses like Kentucky bluegrass (Poa pratensis).

Status note: Since this species is restricted to woodlands and has not been found on BLM lands in Montana, it could be dropped from BLM "Watch" status.

Mentzelia nuda, Bractless Mentzelia (G5, S1)

County Distribution: We documented this species from three locations in the northeastern corner of Powder River County; these were the first county records for it. Prior to this, it had not been reported anywhere in Montana since 1957.

Ecology and management considerations: In Powder River County, it was found in blowouts associated with outcrops, and on the sandstone outcrops themselves. It could be vulnerable to road construction, subdivision, and exotic species invasion, however we identified no immediate management concerns.

Phlox andicola, Plains Phlox (G4, S2)

County Distribution: We discovered this species at one location in the southeastern corner of Powder River County; this was the first record of it for the county.

Ecology and management considerations: The single Powder River County population was found in a partially-revegetated blowout with prairie sandreed (Calamovilfa longifolia), sandhills bluestem (Andropogon hallii), lemon scurfpea (Psoralea lanceolata) and yucca (Yucca glauca). It is an early- to mid-succession species of plains and woodlands, and is subject to encroachment by better-competing species in more productive settings. Moderate levels of grazing and disturbances that reduce competition may benefit the species. Anecdotal observations indicate it is favored by fall fire and winter grazing. 
Physaria brassicoides, Double Bladderpod (G5, S2)

County Distribution: It occurs in southwestern and possibly northeastern areas of Powder River County where there are sandstone outcrops.

Ecology and management considerations: Double bladderpod is restricted to sandy or stony soil of open grassland slopes on the plains. In Powder River County, it occupies secondary range. It grows where the vegetation is sparse, often on steep slopes where the slope is unstable and there is little or no profile development, and is vulnerable to competition from invasive exotics. Seeding of sweetclover (Melilotus spp.) should be avoided near its habitat. It could also be vulnerable to road widening, maintenance, and herbicide treatment.

Psoralea hypogaea, Little Indian Breadroot (G5T4, S2S3)

County Distribution: We found this plant on sandstone outcrops in three of the four corners of Powder River County, and there are more records of it here than in any other Montana county. It was previously reported from single isolated populations in smaller-scale studies (Heidel 1994, Heidel 1997, Vanderhorst et al. 1998). The sandstone outcrops of Powder River County are widespread but mostly small and isolated, so these new location records suggest that the species is likely more widespread than previously known.

Ecology and management considerations: This plant occupies ridgetop blowouts, and loose sand slopes around isolated sandstone outcrops and those along the Powder River valley. Initial observations indicate that it is not sensitive to grazing. The size of populations appears to be directly related to the extent of available habitat, and it appears able to persist in low, isolated pockets.

Status note: As a result of this inventory work, Little Indian Breadroot has been dropped as a state species of concern, and we recommend that BLM drop it from "Watch" designation.

\section{VEGETATION COMMUNITIES}

Based on our field surveys and previous studies, we have now documented a total of 46 native vegetation communities in Powder River County. These are listed in Table 4. Appendix E provides detailed descriptions for 32 of these vegetation types. Where information is available, these include composition and distinguishing attributes, environmental setting, state and county distributions, global and state status, and ecological or management considerations (NatureServe 2002). State status ranks for communities should be considered preliminary and will continue to be reviewed and revised as we acquire new information.

Several vegetation types were particularly noteworthy on BLM lands in the county, either by their extent and good condition and/or as distinctive types that are uncommon or range-limited. In addition to collecting data from vegetation plots to better document and understand these communities, we have also identified areas where they are particularly well-represented in high quality condition, within ecologically intact landscapes.

The discussion below highlights a few of the significant communities and representative areas that we documented during our surveys. Each area mentioned by name is summarized with a site profile in Appendix $\mathrm{B}$, which includes photographs and a map showing its generalized location and extent. 
Table 4. Plant Associations found in Powder River County

\begin{tabular}{|c|c|c|}
\hline Scientific Name & $\begin{array}{c}\text { Global } \\
\text { Rank }\end{array}$ & $\begin{array}{l}\text { State } \\
\text { Rank }\end{array}$ \\
\hline \multicolumn{3}{|l|}{ WOODLAND } \\
\hline Fraxinus pennsylvanica / Prunus virginiana Forest & G3? & $\mathrm{S} 2 \mathrm{~S} 3$ \\
\hline Juniperus scopulorum / Piptatherum micranthum (= Oryzopsis micrantha) Woodland & G3G4 & S3 \\
\hline Juniperus scopulorum / Pseudoroegneria spicata Woodland & G4 & S4 \\
\hline Pinus ponderosa / Carex inops ssp. heliophila Woodland & G3G4 & S3S4 \\
\hline Pinus ponderosa / Festuca idahoensis Woodland & G4 & S4 \\
\hline Pinus ponderosa / Juniperus horizontalis Woodland & G3? & S3 \\
\hline Pinus ponderosa / Pseudoroegneria spicata Woodland & G4 & S4 \\
\hline Pinus ponderosa / Prunus virginiana Forest & G3 & S4 \\
\hline Populus deltoides / Symphoricarpos occidentalis Woodland & G2G3 & $\mathrm{S} 2 \mathrm{~S} 3$ \\
\hline \multicolumn{3}{|l|}{ SHRUBLAND } \\
\hline Artemisia tridentata ssp wyomingensis/ Pascopyrum smithii Shrub Herbaceous Vegetation & G4 & S? \\
\hline Artemisia tridentata ssp. wyomingensis / Pseudoroegneria spicata Shrubland & G5? & S5? \\
\hline Artemisia tridentata ssp. wyomingensis - Atriplex confertifolia Shrubland & G3G5 & S3 \\
\hline Artemisia cana / Pascopyrum smithii Shrubland & G4 & S4 \\
\hline Artemisia cana ssp. cana / Pascopyrum smithii Shrub Herbaceous Vegetation & G4 & $\mathrm{S} ?$ \\
\hline Atriplex gardneri / Pascopyrum smithii Dwarf-Shrubland & G3 & S3 \\
\hline Krascheninnikovia lanata / Hesperostipa (= Stipa) comata Dwarf-Shrubland & G3 & S3 \\
\hline Rhus trilobata / Pseudoroegneria spicata Shrub Herbaceous Vegetation & G4 & S4 \\
\hline Salix exigua Temporarily Flooded Shrubland & G5 & S5 \\
\hline Sarcobatus vermiculatus / Artemisia tridentata Shrubland & G4 & S4 \\
\hline Sarcobatus vermiculatus / Pseudoroegneria spicata Shrubland & G3 & S3 \\
\hline Sarcobatus vermiculatus / Pascopyrum smithii Shrub Herbaceous Vegetation & G4 & S4 \\
\hline Symphoricarpos occidentalis Temporarily Flood Shrubland & G4G5 & S4S5 \\
\hline \multicolumn{3}{|l|}{ HERBACEOUS VEGETATION } \\
\hline Andropogon hallii - Calamovilfa longifolia Herbaceous Vegetation & G4G5 & $\mathrm{S} ?$ \\
\hline Andropogon hallii - Carex inops ssp. heliophila Herbaceous Vegetation & G3 & S3 \\
\hline Calamovilfa longifolia - Carex inops ssp. heliophila Herbaceous Vegetation & G3 & S3? \\
\hline Calamovilfa longifolia - Hesperostipa (= Stipa) comata Herbaceous Vegetation & G3 & S3 \\
\hline Carex nebrascensis Herbaceous Vegetation & G4 & S4 \\
\hline Carex pellita (= lanuginosa) - Calamagrostis stricta Herbaceous Vegetation & G3G5 & S3? \\
\hline Eleocharis palustris Herbaceous Vegetation & G5 & S5 \\
\hline Festuca idahoensis - Carex inops ssp. heliophila Herbaceous Vegetation & G3 & S3 \\
\hline Hesperostipa $(=$ Stipa $)$ comata - Carex filifolia Herbaceous Vegetation & G4 & S4 \\
\hline Hesperostipa $(=$ Stipa $)$ comata - Carex inops ssp. heliophila Herbaceous Vegetation & G4 & S4 \\
\hline Hesperostipa $(=$ Stipa $)$ comata - Bouteloua gracilis - Carex filifolia Herbaceous Vegetation & G5 & $\mathrm{S} ?$ \\
\hline Juncus balticus Herbaceous Vegetation & G5 & S5 \\
\hline Pascopyrum smithii Herbaceous Vegetation & G3G5Q & S4 \\
\hline Pascopyrum smithii - Bouteloua gracilis - Carex filifolia Herbaceous Vegetation & G4 & S4 \\
\hline Pascopyrum smithi - Hordeum jubatum Herbaceous Vegetation & G4 & $\mathrm{S} ?$ \\
\hline Phalaris arundinacea Western Herbaceous Vegetation & G5 & S4 \\
\hline Pseudoroegneria spicata - Bouteloua curtipendula Herbaceous Vegetation & G3 & S3 \\
\hline Pseudoroegneria spicata - Carex filifolia Herbaceous Vegetation & G4 & S4 \\
\hline Pseudoroegneria spicata - Pascopyrum smithii Herbaceous Vegetation & G4 & S4 \\
\hline Schizachyrium scoparium - Bouteloua (curtipendula, gracilis) / Carex filifolia Herbaceous Vegetation & G3G4 & $\mathrm{S} ?$ \\
\hline Schizachyrium scoparium (= Andropogon scoparius) - Carex inops ssp. heliophila Herbaceous Vegetation & G3 & S3 \\
\hline Schoenoplectus (=Scirpus) pungens Herbaceous Vegetation & G3G4 & S3 \\
\hline Spartina pectinata Western Herbaceous Vegetation & G3? & S3? \\
\hline \multicolumn{3}{|l|}{ SPARSE VEGETATION } \\
\hline Eriogonum pauciflorum - Gutierrezia sarothrae Badlands Sparse Vegetation & G4G5 & $\mathrm{S}$ ? \\
\hline
\end{tabular}




\section{$\underline{\text { Grasslands }}$}

Pascopyrum smithii - Hesperostipa comata (western wheatgrass - needle-and-thread) and Pascopyrum smithii - Buchloe dactyloides (western wheatgrass - buffalo grass)

(See full description of Western wheatgrass Alliance communities in Appendix E, page 30)

Distribution: In Powder River County, western wheatgrass-dominated communities occur on gentle to moderate slopes ranging from $0-35 \%$ and it is characteristic of the widespread Silty Ecological Site of the 10-14 inch precipitation zone. This type is prevalent on gentler slopes within the Elso-MidwayThurlow and the Elso-Remmit-Ocean Lake soil associations derived from calcareous shales. It also occurs on Silty Ecological Sites on well-drained deep-loam soils of the Elso - Ocean Lake association to the north. It is occasional on upland and bench positions with suitable substrate in the Ringling-CabbaMidway association to the west, a Clayey Ecological Site of the 15-19 inch precipitation zone. In Powder River County, we documented this community with several different co-dominants including Hesperostipa comata and Buchloe dactyloides, the latter having not been previously documented and apparently distinctive to this region. We recorded data from ten plots in this vegetation type and made extensive field notes, with particular emphasis on documenting the communities co-dominated by western wheatgrass and buffalo grass, which were extensive on BLM lands.

Representative sites: One area that is dominated by western wheatgrass - needle-and-thread community in particularly good condition was Five Mile Hill. We documented particularly good representation of the distinctive western wheatgrass - buffalo grass community in two areas: Little Powder Hills and Biddle Hills.

Ecology and management considerations: Although western wheatgrass communities are common throughout a broad geographic range, heavy grazing and lack of fire may cause many stands to have a high proportion of exotics. In the past, fire likely occurred commonly in this type. Fire, both aboriginaland lightening-caused, was a regular part of this landscape. Fire-return intervals have been considerably lengthened since settlement by European-Americans. Vast (singly and in the aggregate) black-tailed prairie dog (Cynomys ludovicianus) "towns" once developed on the favorable substrates in this community and exploited its vegetation. Prairie dog populations have undergone significant decline since settlement, so much of this type could be in various states of secondary succession, returning from a somewhat denuded state and altered composition created by the prairie dogs as well as bison (Bos bison) that found nutritious forage here.

Calamovilfa longifolia - Hesperostipa comata (prairie sandreed - needle-and-thread) (See full description of this community in Appendix E, page 26)

Distribution: This is a rare upland community that was not previously documented in Montana. It occurs in small patches on the landscape. In Powder River County, this plant association is found in the Sandy Ecological Sites of the 10-14 inch precipitation zone.

Representative sites: We documented this community on the eastern edge of the county along Cabin Creek. This site supports a diversity of other grassland types. The prairie sandreed - needle-and-thread community occurs on the upper portions of well-drained sandy slopes along watercourses and ridges.

Ecology and management considerations: This community can be highly susceptible to invasion by exotic brome grasses and other non-native invasives. 


\section{Andropogon hallii - Calamovilfa longifolia (sand bluestem - prairie sandreed)}

(See full description of this community in Appendix E, page 22)

Distribution: This community types is characteristic of sandy deposits, usually on gentle to moderate slopes, ranging from stabilized rolling to choppy sand dunes. In Montana, where we do not have extensive choppy dune systems, it is uncommon and widely-scattered, associated with active wind erosion. This association occurs at the "rim" of blowouts at Medicine Lakes, but is so small and narrow a vegetation band that it was not included in our description of plant associations in Sheridan County. The unglaciated sedimentary plains of the Fort Union Formation in southeastern Montana provides more habitat for it on active wind erosion features associated with sandstone outcrops, which are widelyscattered in small pockets. In Powder River County, this community is uncommon in areas with sandstone outcrops in at least the eastern end of the county. It occurs within the 10-14 in precipitation zone, and at higher precipitation levels elsewhere. This plant association or closely related ones provides habitat for a number of Montana species of concern, including Chenopodium subglabrum, Cryptantha fendleri, Cyperus schweinitzii, Mentzelia nuda, and possibly others.

Ecology and Management Considerations: Blowouts may occur in this community type, leading to bare soils or subsoils. Blowouts may be related to severe droughts and windstorms, and may occur in conjunction with grazing pressures or fires that reduce the ability of the vegetation cover to stabilize the sand.

Andropogon hallii - Carex inops ssp. heliophila (sand bluestem - sun sedge)

(See full description of this community in Appendix E, page 24)

Distribution: This sand bluestem prairie community type is found in restricted areas of the northern Great Plains of the United States, including southeastern Montana and southeastern North Dakota., where stands are typically less than a hectare in size. It occurs on gentle to steep sloping terrain with sand or sandy loam soil, and in Montana, can occur on slopes of any aspect, with north the least frequent.

Ecology and Management Considerations: Blowouts may occur in this community type, leading to bare soils or subsoils. Blowouts may be caused by severe droughts and windstorms, and may occur in conjunction with grazing pressures that reduce the ability of the vegetation cover to stabilize the sand. This community may be an early successional stage on these blowouts, where vegetation cover and diversity are low.

\section{Pseudoroegneria spicata - Bouteloua curtipendula (bluebunch wheatgrass - sideoats grama)} (See full description of this community in Appendix E, page 36)

Distribution: This mixedgrass association occurs as small to large patches on foothills and sideslopes along major drainages between the Tongue and Powder rivers of southeastern Montana. To date, it has been documented only in southeastern Montana, although potential habitat exists in northeast Wyoming and westernmost North Dakota. It is considered a topo-edaphic climax by Hansen and Hoffman (1988) because it occurs on moderate to steep slopes ( $>45 \%$ ) with large amounts of irregularly shaped, iron oxide porcelainite shale (scoria), produced by fires in contiguous coal beds (however the soils are conventional loams). These harsh sites produce a unique depauperate community with one of the lowest total and graminoid covers of any southeastern Montana community.

Ecology and Management considerations: Given the low cover and patchiness of this type, fires probably burned in a mosaic fashion with reduced intensity. It could be vulnerable to grazing, but stands 
are generally somewhat removed from water. These areas are generally not conducive to alien bromegrasses, but their susceptibility to invasion by other weeds is unknown. Pronghorn antelope (Antilocapra americana) use areas sites for grazing and predator detection.

\section{Shrublands and Shrubland-Grasslands:}

\section{Artemisia tridentata ssp. wyomingensis - Pascopyrum smithii (Wyoming bigsage - western wheat-} grass)

(See full description of this community in Appendix E, page 13)

Distribution: In Powder River County, this widespread Montana community occurs wherever the topography is dissected, and is especially extensive in the extreme southwestern corner of the county. Over most of the county's shale plains, it is concentrated on the steeper slopes (greater than 8\%) giving way to grassland on gentler slopes. It occurs on Thin Silty Ecological Sites, with 10-14 in. precipitation zone. It is not limited to steep slopes in all settings, and prevails at the extreme southwestern border of the county on Silty ecological sites, where elevation is higher.

Representative sites: We found good stands of Wyoming bigsage - western wheatgrass at Chico Buttes and in the Little Powder Hills. Both are in good condition and exist in a landscape that is largely ecologically intact. The Little Powder Hills represents the cool phase of this community, with a codominance of Carex filifolia (three-leaved sedge) in the understory. At Chico Buttes, the understory is co-dominated by Nassella viridula (green needlegrass), indicating a more mesic phase of this vegetation type. The Chico Buttes site also supports a particularly rich stand with species that were scarce or absent elsewhere, including Calochortus nuttallii, (Nuttall's mariposa lily), Besseya wyomingensis, (Wyoming coral-drops), Linum lewisii (prairie flax), and green needlegrass.

Ecology and management considerations: Taylor and Holst (1976) refer to an "upland praririe sagebrush ecosystem" of the Ashland District and note that this sagebrush ecosystem overlaps strongly with upland grassland, appearing as an edaphic difference in places, and as a grazing disclimax in others. In Powder River County, we found many areas of this community in good condition, indicating its edaphic origin. Wyoming bigsage is killed within prairie dog towns. In Powder River County, vegetation sampling was conducted on a bench along Buffalo Creek in what appeared to be a long-abandoned prairie dog town, even though there were no signs of burrow mounds remaining. Elsewhere on the bench, Wyoming bigsage dominated in identical settings. In the abandoned prairie dog town, there was $50 \%$ cover of Wyoming bigsage and 10\% cover of both Poa secunda (Sandberg bluegrass) and Bromus japonicus (Japanese brome), with high litter accumulation (greater than 60\%). Perhaps the fertilizing and churning influence of the prairie dogs heightened productivity and impeded re-establishment of Wyoming bigsage in the high vegetation and/or high litter cover. Under heavy grazing pressure, the cover of exotic and increaser species like Japanese brome, Hedeoma hispida (rough pennyroyal), Plantago patagonica (woolly plantain), and Vulpia octoflora (slender 8-flowered fescue) increases greatly.

Artemisia tridentata ssp. wyomingensis - Buchloe dactyloides (Wyoming bigsage - buffalo grass) (This is referenced in Appendix E, page 15 under Wyoming bigsage-western wheatgrass shrubland)

Distribution: We documented this vegetation type for the first time in Powder River County during these surveys, where it occurred on BLM lands in much of the county. This community type has not been well-documented elsewhere in the northern Great Plains.

Representative sites: We identified two particularly high quality landscapes with good stands of this community type. In the Biddle Hills, Wyoming bigsage - buffalo grass occurred over about half a 
township in essentially undisturbed natural condition, within a functionally intact landscape. Buffalo grass is also co-dominant (with western wheatgrass) in the grasslands of the Biddle Hills. One of the few areas in the county where we found the Wyoming bigsage - buffalo grass community on clay substrate (Arvada-Bone complex, rather than the typical silt substrate) was at the Cabin Creek site. It occurs there in good condition within an ecologically intact landscape.

Ecology and management considerations: We have no information that is specific to this type.

\section{Woodlands:}

\section{Pinus ponderosa-Pseudoregneria spicata (ponderosa pine - bluebunch wheatgrass)}

(See full description of this community in Appendix E, page 10)

Distribution: In Powder River County, this association is found on Shallow to Sandy and Silty Ecological Sites in both 10-14 and 15-19 inch precipitation zones. It occurs on slopes with coarse soils, often with a high gravel or rock content, and occurs mostly on steep southerly aspects.

Representative sites: We identified ponderosa pine - bluebunch wheatgrass stands at Five Mile Hill that are good condition second growth. This site is one of several areas near Broadus that best represent the "park-like" nature of the ponderosa pine community type. The Buffalo Breaks along the southwestern edge of the county, east of the Powder River, has a complex system of steep ridge slopes covered by a ponderosa pine woodland with some Juniperus scopulorum (Rocky Mountain juniper ) in the understory. The area is impressive in its extent and complexity, and supports a diverse complex of woodland, steppe and grasslands similar to nearby National Forest lands.

Ecology and management considerations: Fire likely occurred at regular intervals in this type; documentation on fire frequency is not available. The lack of Rocky Mountain juniper in many stands may be attributable to past fires killing this species and leaving the ponderosa pine overstory intact; this scenario has been documented by Culwell et al. (1991) in the Bull Mountains of central Montana.

\section{Juniperus scopulorum - Piptatherum micranthum Woodland (Rocky Mountain juniper - little-seed mountain ricegrass)}

(See full description of this community in Appendix E, page 6)

Distribution: In Montana, this association is best-developed on sheltered aspects in dissected sedimentary plains. Within Powder River County, it is widely-scattered on thin silty ecological conditions, along northeastern escarpments and dissected terrain along the south end of the Powder River in the southwestern corner of the County. This type closely intergrades with Juniperus scopulorum / Pseudoroegneria spicata and both may be represented on the same slope or on opposite aspects of the same landform, as we found them in the dissected terrain along the Powder River.

Ecology and Management Considerations: This plant association is in relatively moist habitat that is not as prone to burning as surrounding vegetation types, but is highly flammable when dry. Rocky Mountain juniper is readily killed by fire; once ignited the crowns are almost always completely incinerated.

It often has grassland or steppe openings that influence the levels of overall livestock use. Signs of fencepost cuttings are ubiquitous in the stands and the changes brought on by this history need to be further addressed in characterizing stand structure. 


\section{RECOMMENDATIONS FOR FUTURE WORK}

While this study added a great deal to knowledge of the vegetation and ecology of Powder River County, it is far from comprehensive. One limitation was our focus on BLM lands - and principally large blocks within those lands. While these lands support a diversity of community types, many in good to excellent condition, they also tend to concentrate in certain types of landscapes, resulting in oversampling of some features and undersampling of others.

For example, the more mesic river valleys and major draws stand out as one of the least-documented vegetation complexes in the county, and one that we did not address, since they occur almost entirely on private lands. Riparian communities have undergone major changes, including conversion to pasture grasses and widespread loss of cottonwood regeneration. However, they continue to be extremely important to a diversity of wildlife species. An understanding of biological resources in drainages and associated lowlands will be particularly important due to their favorability as locations for coalbed methane wells and associated facilities. These areas are also of tremendous importance for a diversity of wildlife species. This study did not address fauna at all, and future efforts should include wildlife, emphasizing species of concern and lesser-known groups such as small mammals, reptiles and amphibians, and songbirds. It may also be valuable to better understand the effects of existing riparian modifications on wildlife species populations and diversity, to help in evaluating the impacts of potential future modifications and identify management options.

Forb diversity was relatively low in many of the communities that we documented. This would be worthy of further documentation to determine its extent and to identify patterns related to geology, geography and/or land use history (e.g., sheep grazing).

Much of Powder River County has not yet been extensively invaded by many invasive exotic weeds that pose serious threats elsewhere in the state. Continued documentation of those weeds that are present and/or invading will be important to safeguarding the rangeland values provided by native vegetation communities. We did note a significant presence of Japanese and smooth brome. The ecological impact of these species on the native communities and species has not been evaluated, to our knowledge, and may be worthy of further attention.

Our survey efforts were also limited by time and the scale of the project, which was relatively modest. We designed our approach to provide a representative overview of vegetation types on BLM lands, however many tracts were not visited, and among those that we did survey, none were systematically inventoried and many were far too large to be more than sampled. In addition, portions of the county are quite remote with limited access, which imposed restrictions on the reach of our ground surveys.

It would also be worthwhile to extend survey work to significant state land holdings in the southeastern part of the county, and into Custer National Forest in the west. All of these additional efforts would contribute to developing a truly integrated portrait of the biological resources and dynamics in this large, diverse and relatively intact landscape. 


\section{LITERATURE CITED}

Booth, W. E. 1950. Flora of Montana, part 1, conifers and monocots. The Research Foundation at Montana State College, Bozeman, MT. 232 pp.

Booth, W.E. and J. C. Wright. 1966. Flora of Montana, Part II. Dicotyledons. Montana State University, Bozeman, MT. 305 pp.

Connelly, J.W., M.A. Schroeder, A.R. Sands and C.E. Braun, 2000. Guidelines to manage sage grouse populations and their habitats. Wildlife Society Bulletin 28 (4): 967-985.

Culwell, L. D. 1979. Vegetation communities of the Coal Creek study area, Powder River County. Report to Coal Creek Mining Company. Western Technology and Engineering, Inc. Helena, MT.

Braun, C. E., O.O. Oedekoven, and C. L. Aldridge, 2002. Oil and Gas Development in Western North America: Effects on Sagebrush Steppe Avifauna with Particular Emphasis on Sage-grouse.

Transactions of the North American Wildlife and Natural Resources Conferences. 67: In Press.

Dorn, R. D. 1984. Vascular Plants of Montana. Mountain West Publishing, Cheyenne, WY. 276 pp.

Dorn, R. D. 1992. Vascular Plants of Wyoming. Mountain West Publishing, Cheyenne, WY. 340 pp.

Faber-Langendoen, D. 1999. Terrestrial Vegetation of the midwestern United States. Compiled community characterization abstract in draft form. Midwest Office of The Nature Conservancy, Minneapolis, Minn.

Fertig, W., C. Refsdal, and J. Whipple. 1994. Wyoming Rare Plant Field Guide. Wyoming Rare Plant Technical Committee, Cheyenne, WY.

Great Plains Flora Association. 1977. Atlas of the flora of the Great Plains. Iowa University Press, Ames, IA. 600 pp.

Great Plains Flora Association. 1986. Flora of the Great Plains. University Press of Kansas, Lawrence, Kansas. 1392 pp.

Grossman, D.H., D. Faber-Langendoen, A.S. Weakley, M. Anderson, P. Bourgeron, R. Crawford, K. Goodin, S. Landaal, K. Metzler, K. Patterson, M. Pyne, M. Reid, and L. Sneddon. 1998. International Classification of Ecological Communities: Terrestrial Vegetation of the United States. Volume I. The national vegetation classification system: development, status, and applications. The Nature Conservancy, Arlington, Virginia. USA. 126 pp.

Hansen, P. L. and G. R. Hoffman. 1988. The vegetation of the Grand River/Cedar River, Sioux and Ashland Districts of the Custer National Forest: a habitat type classification. Gen. Tech. Rep. RM-157. USDA Forest Service, Rocky Mountain Forest and Range Experiment Station. Fort Collins, CO. $68 \mathrm{pp}$.

Heidel, B. L. 1994. Survey for PSORALEA HYPOGAEA in the Great Falls Resource Area, Lewistown District. Unpublished report to the Bureau of Land Management, Montana. Montana Natural Heritage Program. 22 pp. plus appendices. 
Heidel, B. L. and K. H. Dueholm. 1995. Sensitive plant species survey in the Sioux District of Custer National Forest, Carter County, Montana and Harding County, South Dakota. Unpublished report to the Custer National Forest. Montana Natural Heritage Program, Helena, MT. 95 pp. plus appendices.

Heidel, B. and H. Marriott. 1996. Sensitive plant species survey in the Ashland District, Custer National Forest. Report to the U.S. Forest Service. Montana Natural Heritage Program, Helena.

Heidel, B.L. 1997. Preliminary Botanical Survey in the Tongue River Area, Montana. Unpublished report. Montana Natural Heritage Program, Helena. 11 pp. plus appendices and map.

Hitchcock, C. L. and A. Cronquist. 1973. Flora of the Pacific Northwest. University of Washington Press, Seattle. 730 pp.

Husby, P., J. Antos, J. Elliott and T. Olson. 1979. Vegetation inventory and analysis of the Montco project area. Report to MONTCO. Olson-Eillott and Associates. Helena, MT.

Kartesz, J.T. 1999. A Synonymized Checklist and Atlas with Biological Attributes for the Vascular Flora of the United States, Canada, and Greenland. First Edition. In: Kartesz, J.T. and C.A. Meacham. Synthesis of the North America Flora, Version 1.0, North Carolina Botanical Garden, Chapel Hill, NV. August.

Montagne, C., L. C. Munn, G. A. Nielsen, J. W. Rogers and H. E. Hunter. 1982. Bulletin 744. Bozeman, MT. Montana Agricultural Experiment Station, Montana State University. 95 pp.

Montana Native Plant Society. 1993. Guidelines for collecting plants. Reprint from Kelseya Newsletter. Bozeman, MT. 2 pp.

Natural Resource Conservation Service. 1980. Draft: Report of Field Review of Mapping Units in Soil Survey of Powder River County area, Montana. June 6, 1980.

Natural Resource Conservation Service. 2001. Plants Database. http.//plants.usda.gov.plants/. Data accessed in May, 2001.

NatureServe. 2002. International Classification of Ecological Communities: Terrestrial Vegetation. Natural Heritage Central Databases. NatureServe, Arlington, VA.

Parker, J. L., L. R. Guptill, K. M. Bajema, W. A. Berg, L. Logan, and R. E. Adams. 1971. Soil Survey of Powder River Area, Montana. Soil Conservation Service (Natural Resources Conservation Service), Bozeman, MT.

Ross, R. L. and H. E. Hunter. 1976. Climax vegetation of Montana based on soils and climate. Bozeman, MT. U.S. Department of Agriculture, Soil Conservation Service. 64 pp.

Taylor, J. E. and T. L. Holst. 1976. Grass and shrub plant community classification. USFS Contract Research Project 26-3494. Final Report, Ashland District, US Forest Service.

The Nature Conservancy. 1999. Ecoregional Conservation in the Northern Great Plains Steppe. 181 pp. 
Vanderhorst, J., Cooper, S. V. and B. Heidel. 1998. Botanical and vegetation survey of Carter County, Montana. Unpublished report to Bureau of Land Management. Montana Natural Heritage Program, Helena, MT. 116 pp. + app. 
Appendix A: Global / State Rank Definitions 


\section{HERITAGE PROGRAM RANKS}

The international network of Natural Heritage Programs employs a standardized ranking system to denote global (range-wide) and state status (Association for Biodiversity Information 2001). Species are assigned numeric ranks ranging from 1 (critically imperiled) to 5 (demonstrably secure), reflecting the relative degree to which they are "at-risk". Rank definitions are given below. A number of factors are considered in assigning ranks -- the number, size and distribution of known "occurrences" or populations, population trends (if known), habitat sensitivity, and threat. Factors in a species' life history that make it especially vulnerable are also considered (e.g., dependence on a specific pollinator).

\section{RANK DEFINITIONS}

G1 S1 Critically imperiled because of extreme rarity and/or other factors making it highly vulnerable to extinction.

G2 S2 Imperiled because of rarity and/or other factors making it vulnerable to extinction.

G3 S3 Vulnerable because of rarity or restricted range and/or other factors, even though it may be abundant at some of its locations.

G4 S4 Apparently secure, though it may be quite rare in parts of its range, especially at the periphery.

G5 S5 Demonstrably secure, though it may be quite rare in parts of its range, especially at the periphery.

GU SU Possibly imperiled, but status uncertain; more information needed.

GA SA Native in nearby states, but in Montana believed to be accidentally introduced, deliberately planted, or escaped from plantings.

GH SH Historical, known only from records over 50 year ago; may be rediscovered.

GX SX Believed to be extinct; historical records only.

\section{COMBINATION RANKS}

$\mathrm{G} \# \mathrm{G} \#$ or $\mathrm{S} \# \mathrm{~S} \#$ Indicates a range of uncertainty about the rarity of the species.

\section{SUBRANKS}

Rank of a subspecies or variety; appended to the species' global rank of the full species, e.g. G4T3.

\section{QUALIFIERS}

Q Taxonomic questions or problems exist, more information needed; appended to the global rank, e.g. G3Q.

? Denotes uncertainty or for numeric ranks, inexactness. 
Appendix B: Site Descriptions 


\section{Site Map for Powder River County}

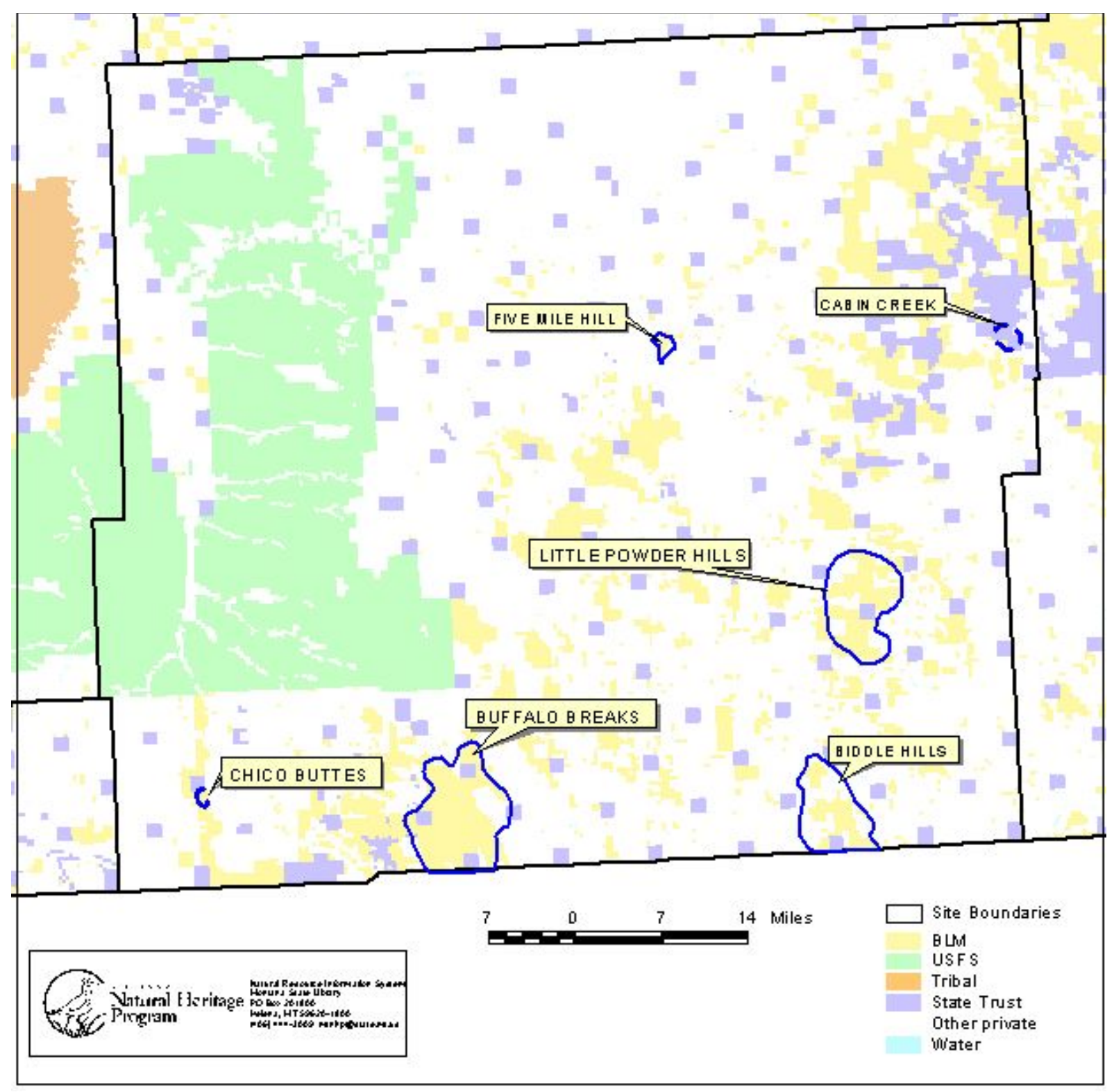




\section{FIVE MILE HILL}

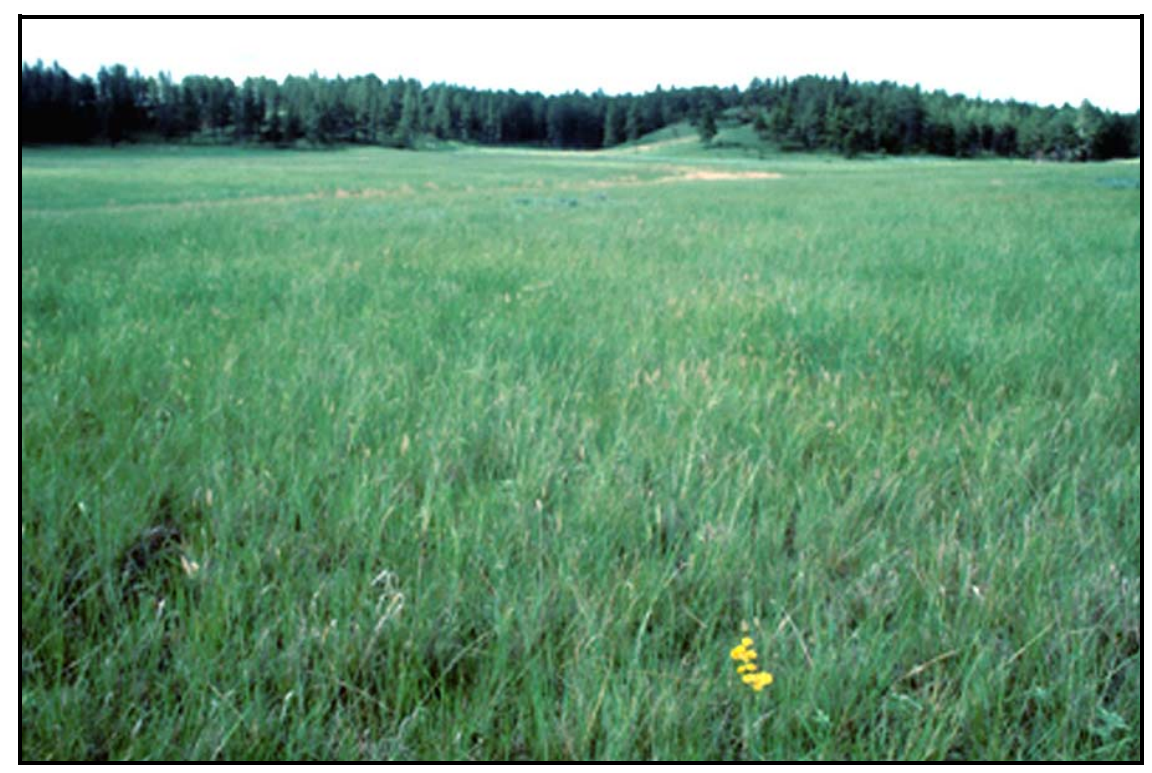

Photo by Bonnie Heidel

\section{Location}

Approximately 3 miles W of Broadus, MT and 2 miles N; public road access on E side of Highway 59.

\section{General Description}

The site is a portion of sandstone outcrop escarpment between the Powder River and Mitzpah River, with pine-covered outcrop knolls and intervening gently rolling grasslands.

\section{Vegetation Communities}

The grassland community is co-dominated by Pascopyrum smithii (western wheatgrass) at $10+\%$ cover and Hesperostipa comata (needle-and-thread) at 30\% cover. Short-stature graminoids are not readily apparent but the cover of Carex inops (sun sedge) cover exceeds 10\%. The most important forbs in terms of cover are Androsace occidentalis (western rockjasmine) and Sphaeralcea coccinea (red globemallow). Bouteloua gracilis (blue gramma) increases and western wheatgrass decreases in higher topographic positions. Plot data was taken in mesic habitat at the lower end of the gradient, perhaps similar in site characteristics to adjoining farmland.

The open woodland community is dominated by Pinus ponderosa (ponderosa pine) at approximately $5 \%$ and Pseudoroegneria spicata (bluebunch wheatgrass) at $+/-20 \%$, sometimes joined by sun sedge and Schizachyrium scoparium (little bluestem) at 0-3\%. The associated forbs are present in trace amounts, including Campanula rotundifolia (American harebell), Heterotheca villosa (hairy golden-aster), and Brickellia eupatorioides (thoroughwort brickerbush).

\section{Environmental Characteristics}

The series of small hills is typical of escarpments on the plains, covered by pine woodland, interspersed with grassland and sparse vegetation. Soils range from gravelly silt loams to loamy sands, and fall within the Ringling slaty loam, 20-50\% slope unit. The gentle northern toe-slope setting is part of a well-drained perimeter that flanks the sandstone and scoria outcrops of Five Mile Hill, on Hapley and Relan loams, with a 4-8\% slope. The pine-covered hills and open perimeter lie within productive up- 
lands that are either converted to farmland or tamegrass, or more intensively utilized.

\section{Significance}

The grassland community represents a "large patch" type in good condition, within a landscape that is ecologically intact in part. The botanical and ecological diversity is good but limited by size, and in places by condition. The ponderosa pine community is a "large patch" type represented here by secondgrowth stands in good condition. It is among the areas near Broadus that best represents a "park-like" pine community, and could serve as a stewardship demonstration site.

\section{Land Management}

Public recreation access is provided via a gate and scoria road on the east side of the highway. A trailer for BLM fire-fighting crews is parked in the middle. The area is popular for local recreational use, including parties and target practice.

\section{Exotics}

Annual bromes are common on exposed outcrop slopes and Poa pratensis (Kentucky bluegrass) is common in swales between knolls. 
FIVE MILE HILL

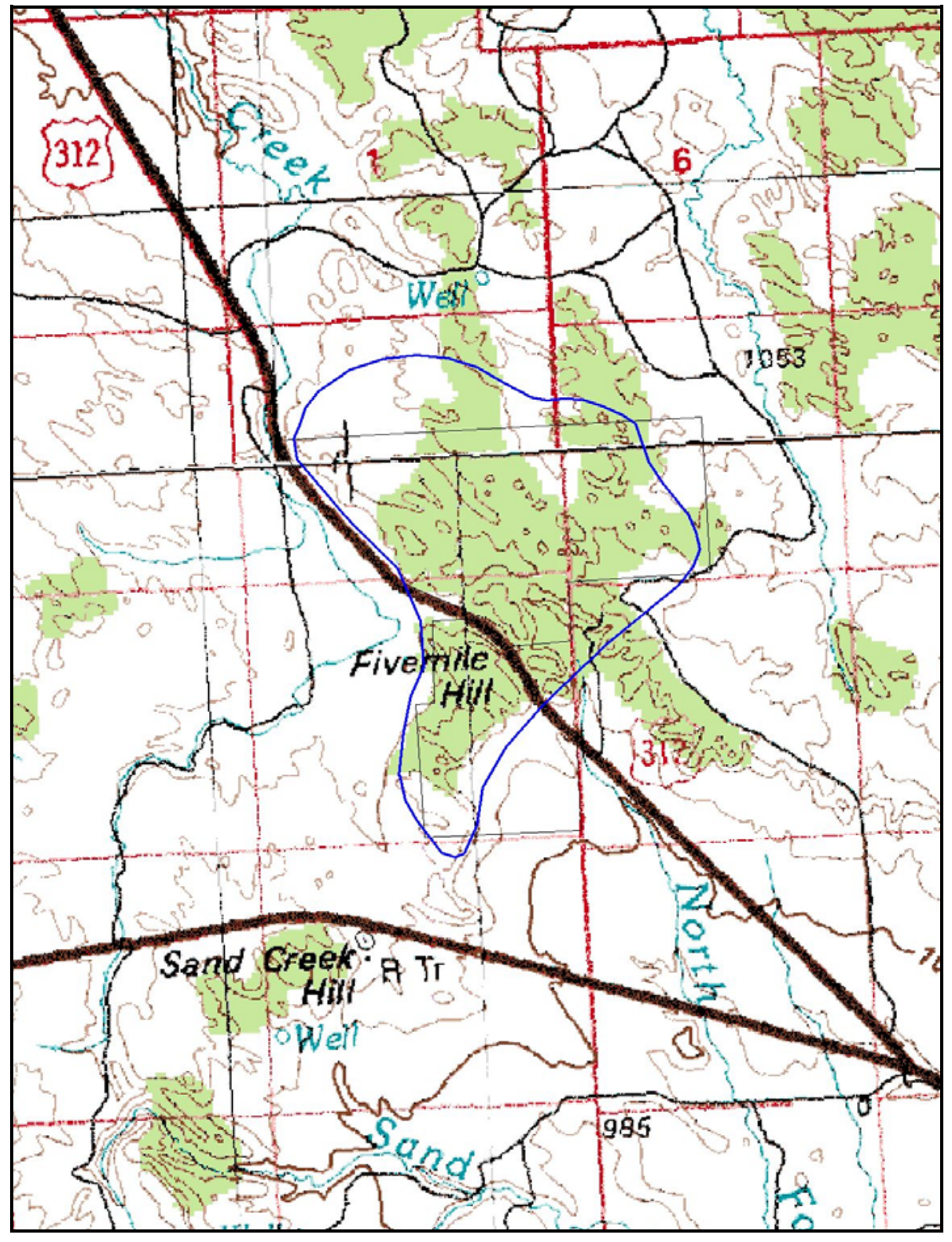




\section{CHICO BUTTES}

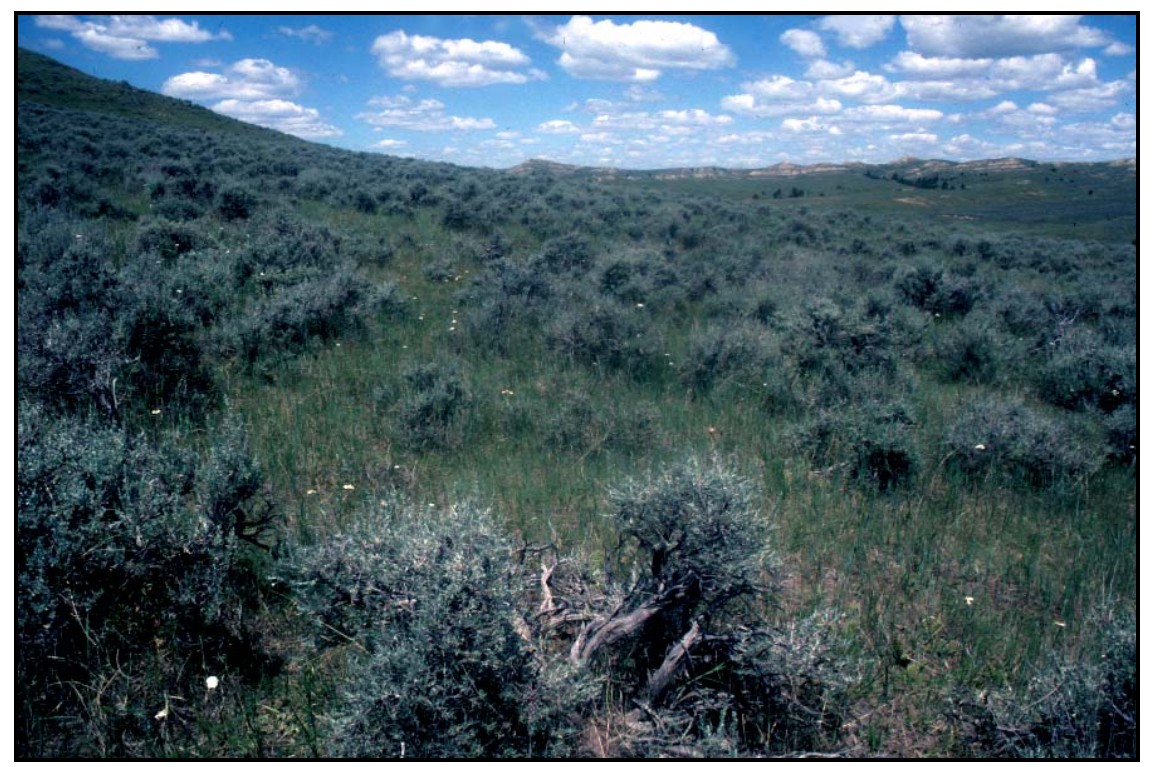

Photo by Bonnie Heidel

\section{Location}

Approximately 17 miles S and 2 miles W of Fort Howes Work Station, in a valley NW of the road.

\section{General Description}

This is a productive Artemisia tridentata ssp. wyomingensis-Pascopyrum smithii (Wyoming big sagebrush-western wheatgrass) shrub-herbaceous community that occupies some of the county's bestcondition rangelands; the community spans dissected terrain and an unmodified watercourse. The area includes the transition from sagebrush community to the surrounding grasslands. Artemisia tridentata ssp. wyomingensis (Wyoming bigsage) cover becomes prevalent to the south and west; our survey was incomplete and limited by access, and this community likely includes additional BLM lands to the south that could not be accessed.

\section{Vegetation Communities}

The area is dominated by Wyoming big sagebrush with cover at or below $20 \%$. The understory is codominated by western wheatgrass and Nassella viridula (green needlegrass) both approaching $20 \%$ cover, and with Koeleria macrantha (prairie junegrass) and Bromus japonicus (Japanese brome) also having between $10-20 \%$ cover. The most common forbs are Achillea millefolium (common yarro), Phlox hoodii (Hood's phlox), Gutierrezia sarothrae (broom snakeweed) and Alyssum desertorum (desert alyssum), approaching $1 \%$ cover. Codominance by green needlegrass indicates the most mesic phase of this association in Powder River County.

\section{Environmental Characteristics}

This is in the only major area of the Kyle-Midway-Cabba soil association in Powder River County, which has a relatively high clay component. It occupies the head of a north-trending valley that cuts into a prominent, open ridge where the valley has among the best soil development in this landscape on the Midway and Elso Rocky Soils, with 35-75\% slope. Grassland vegetation prevails over the ridgetop and sparsely vegetated communities dominate on certain aspects and lithologies of the side-slopes. 


\section{Significance}

The Wyoming bigsage-western wheatgrass community typically occurs as large patches on the landscape; it is present here in good condition in an ecological setting that is largely intact.

\section{Exotics}

Japanese brome is present with $10-20 \%$ cover in the Wyoming bigsage community. 


\section{CHICO BUTTES}

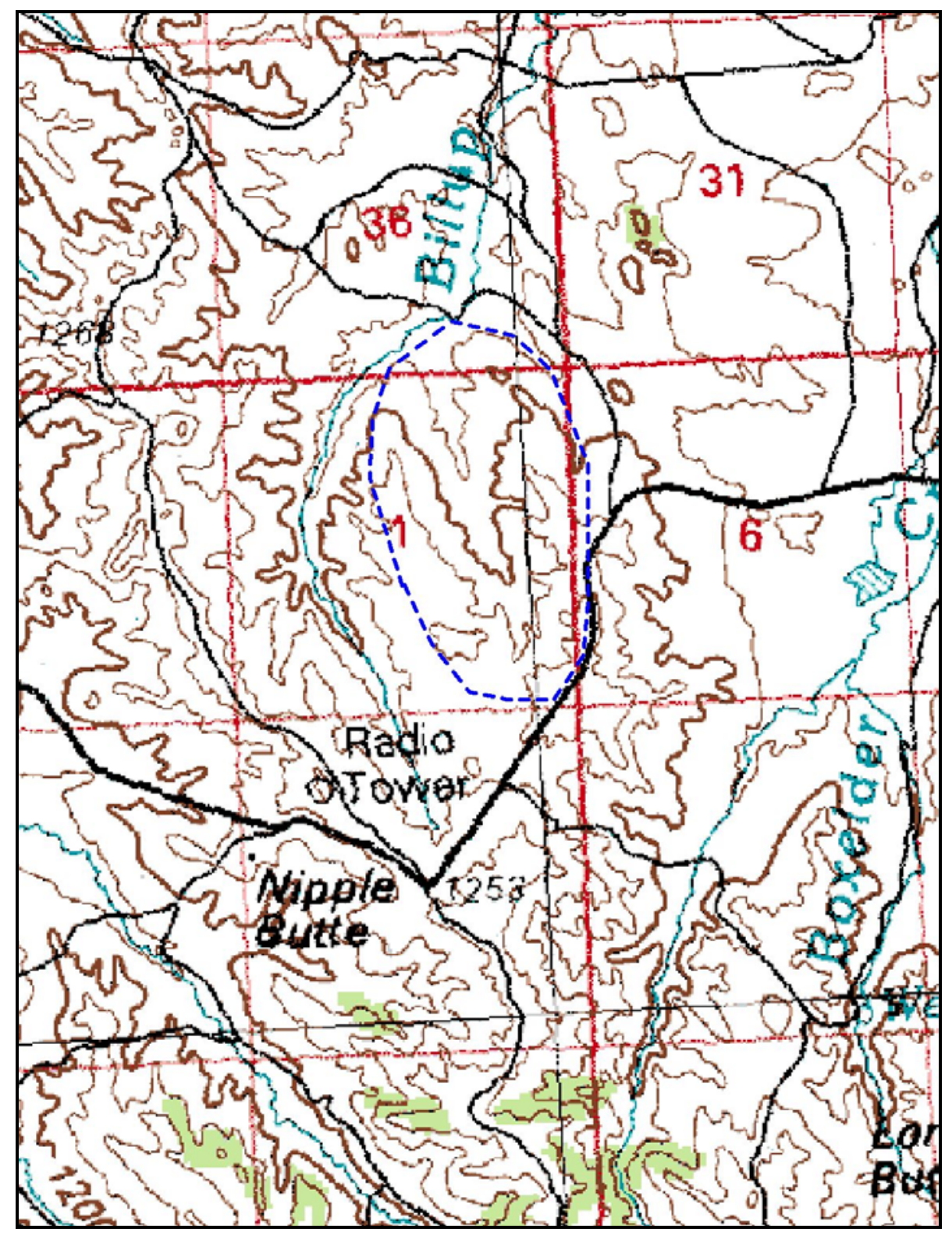




\section{LITTLE POWDER HILLS}

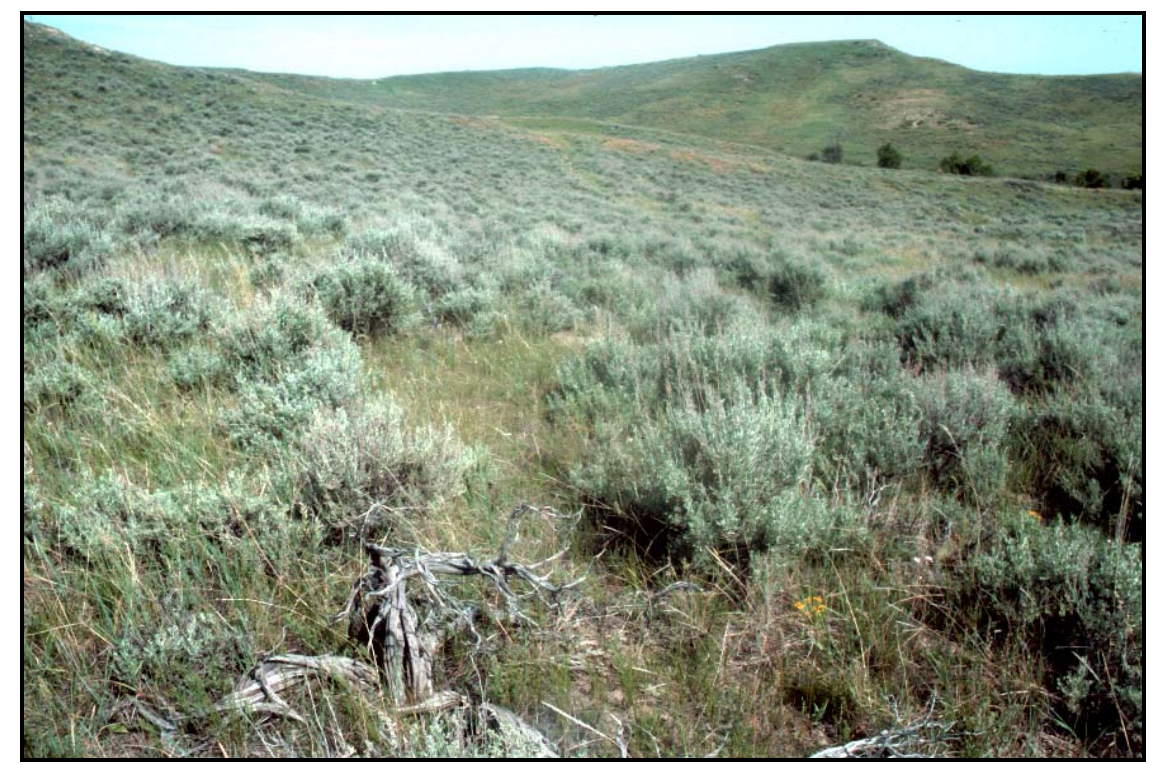

Photo by Bonnie Heidel

\section{Location}

North of Horse Creek, approximately 7 miles N of Biddle, MT, 4.5 miles E on Belle Creek Rd and 1.5 miles $\mathrm{N}$, following a series of turns going primarily $\mathrm{N}$ for about 2.5 miles to the only public access for the site from the south.

\section{General Description}

The Little Powder Hills are a series of ridges and valleys along side tributaries of the Little Powder River. Horse Creek has the broadest valley of those tributaries, with prairie dog towns and some tamegrass hayland. Abrupt, scattered ridgecrests and valley rims have siltstone outcrops, and support the most extensive upland successional communities. Grasslands predominate, grading into sagebrush steppe on steep, upper slopes and in the intact valleybottoms.

\section{Vegetation Communities}

A productive Artemisia tridentata ssp. wyomingensis (Wyoming bigsage) steppe community, with sagebrush cover exceeding 30\%, dominates the higher slopes and topographic positions. The understory is co-dominated by Pascopyrum smithii (western wheatgrass) at over 30\%, Koeleria macrantha (prairie junegrass) at less than $30 \%$, and Carex filifolia (thread-leaved sedge) at less than 20\%. Co-dominance by thread-leaved sedge represents the cool phase of this association in Powder River County.

\section{Environmental Characteristics}

Side tributaries of the Little Powder River dissect the uplands. Grasslands prevail, with scattered ridge outcrops and steppe on their upper north-facing slopes. The shrub communities grade into grassland with decreasing slope and lower topographic position, and into sparsely vegetated communities on exposed aspects. Soils are Midway - Elso, with 8-35\% slope. The Elso and Midway soil series predominate, originating from a siltstone of remarkable uniformity. Widely scattered areas of sandstone outcrops occur at lower elevations. 


\section{Significance}

The Wyoming bigsage steppe is a community that occurs as large patches on the landscape, and is represented here in good condition within a landscape that is largely ecologically intact. This site includes good habitat for Astragalus Barrii (Barr's milkvetch). It also has good to excellent examples of the Pascopyrum smithii - Buchloe dactyloides (western wheatgrass - buffalo grass) plant association, and occupied Cynomys ludovicianus (black-tailed prairie dog) habitat that is probably 500-1000 acres. It is also high quality habitat for Antilocapra americana (pronghorn).

\section{Land Management}

The area is rangeland that spans at least two allotments. A couple inclusions of tamegrass plantings exist as well (unknown whether they are still hayed).

\section{Exotics}

Exotic species are limited to annual bromes and Malcolmia africana (African adder's-mouth). 


\section{LITTLE POWDER HILLS}

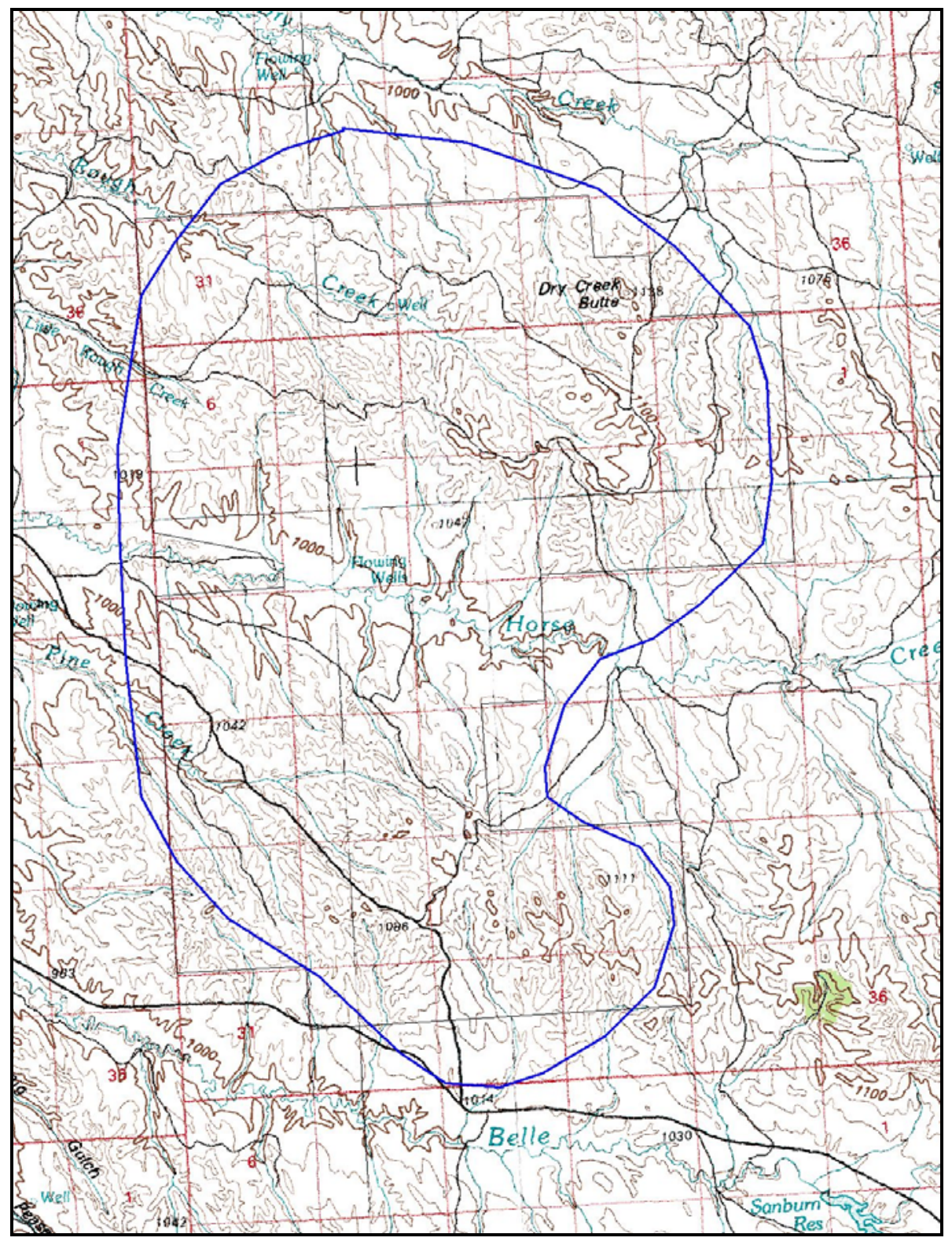




\section{BUFFALO BREAKS}

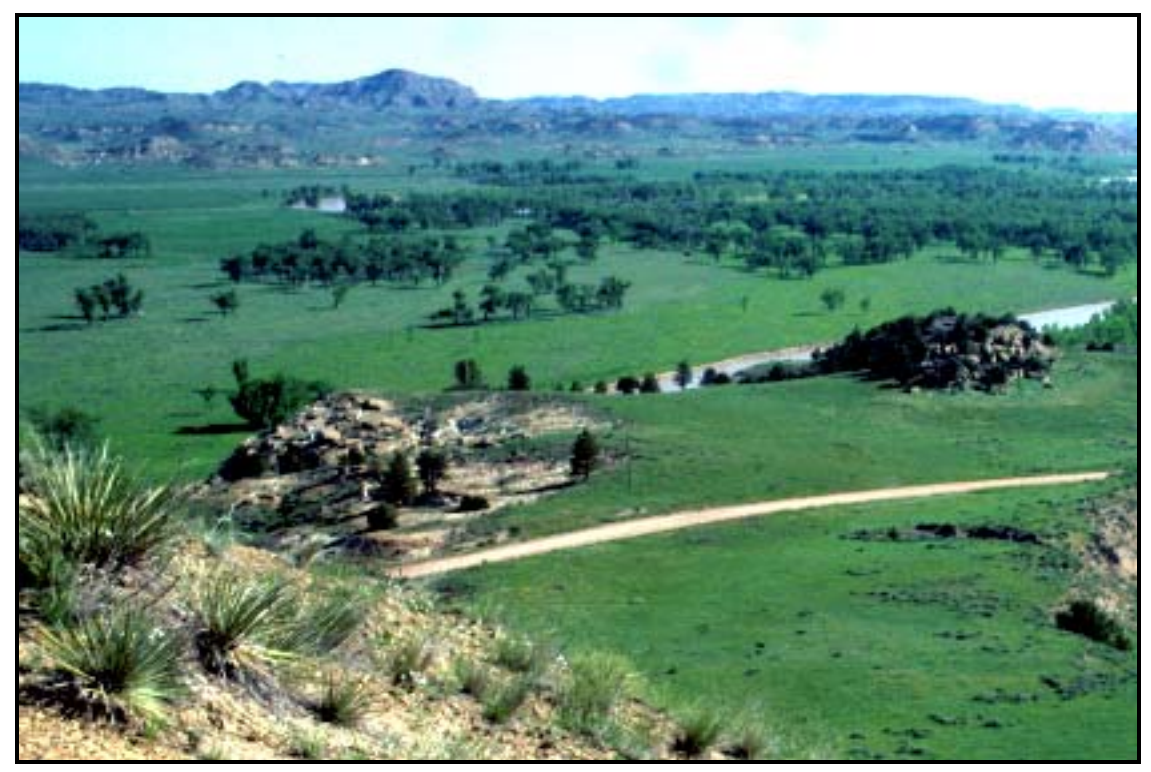

Photo by Bonnie Heidel

\section{Location}

E of Moorehead, MT extending from the Wyoming state line $\mathrm{N}$ along the Powder River to Buffalo Creek and the range of hills paralleling it on the NE.

\section{General Description and Vegetation Communities}

The area is a complex system of steep ridge slopes covered by Pinus ponderosa (ponderosa pine) with some Juniperus scopulorum (Rocky Mountain juniper) surrounding long, flat isolated ridgetops. It also encompasses a segment of the broad Buffalo Creek valley.

\section{Key Environmental Factors}

Soils are part of the Ringling-Cabba-Midway association, with shallow slaty loams and clay loams.

\section{Significance}

This area has a diversity of woodland, steppe and grassland habitats which are similar to nearby National Forest lands on the same soils series, noteable in the extent and complexity more than their condition. It also has high habitat value for big game. Buffalo Creek includes extant and former prairie dog towns, with interesting successional patterns.

\section{Land Management}

The entire area is rangeland. Portions of this area have a history of heavy livestock use, including tracts along the Powder River. Most of the complex lies within a BLM roadless study area. 


\section{BUFFALO BREAKS}

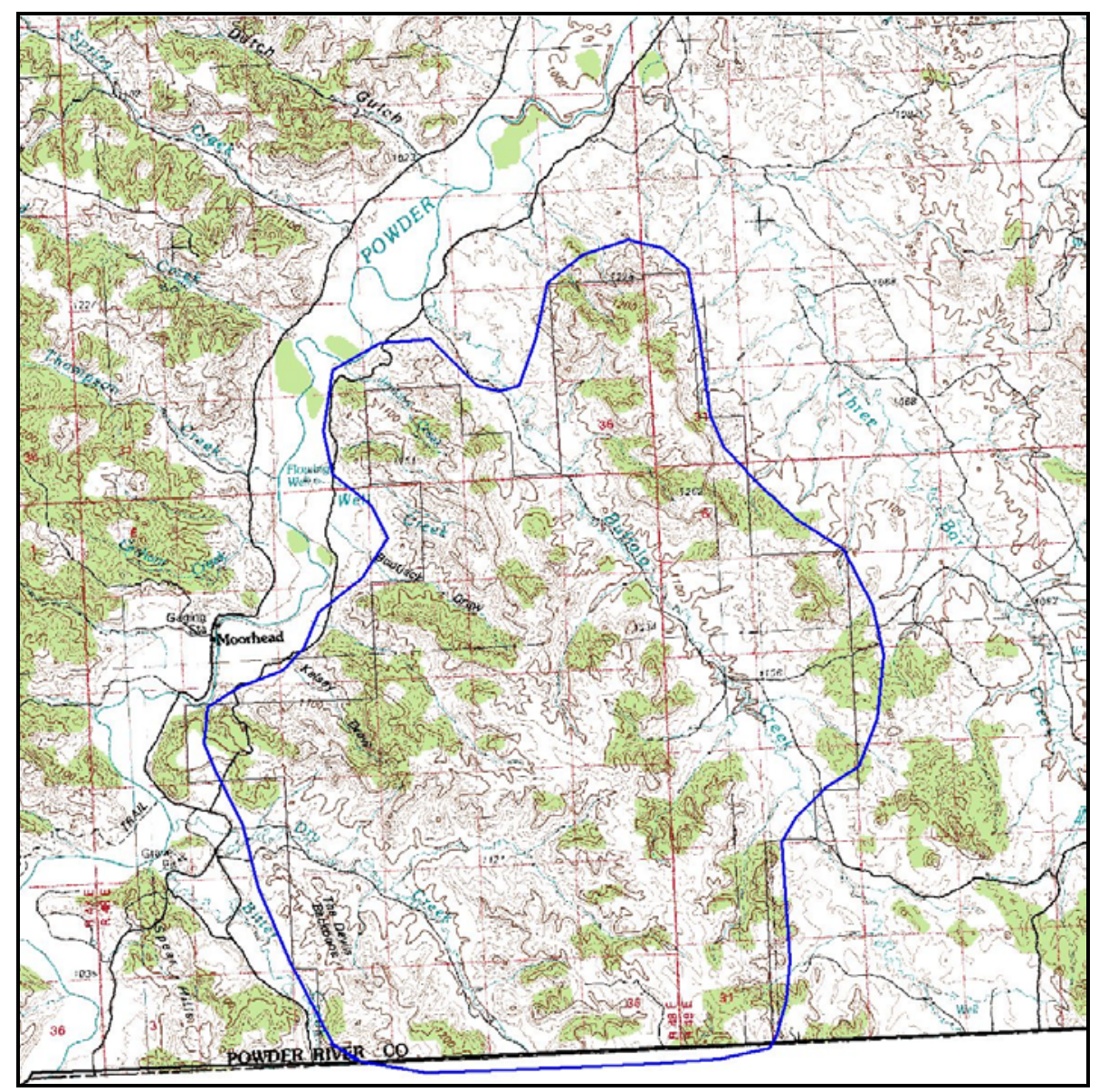




\section{BIDDLE HILLS}

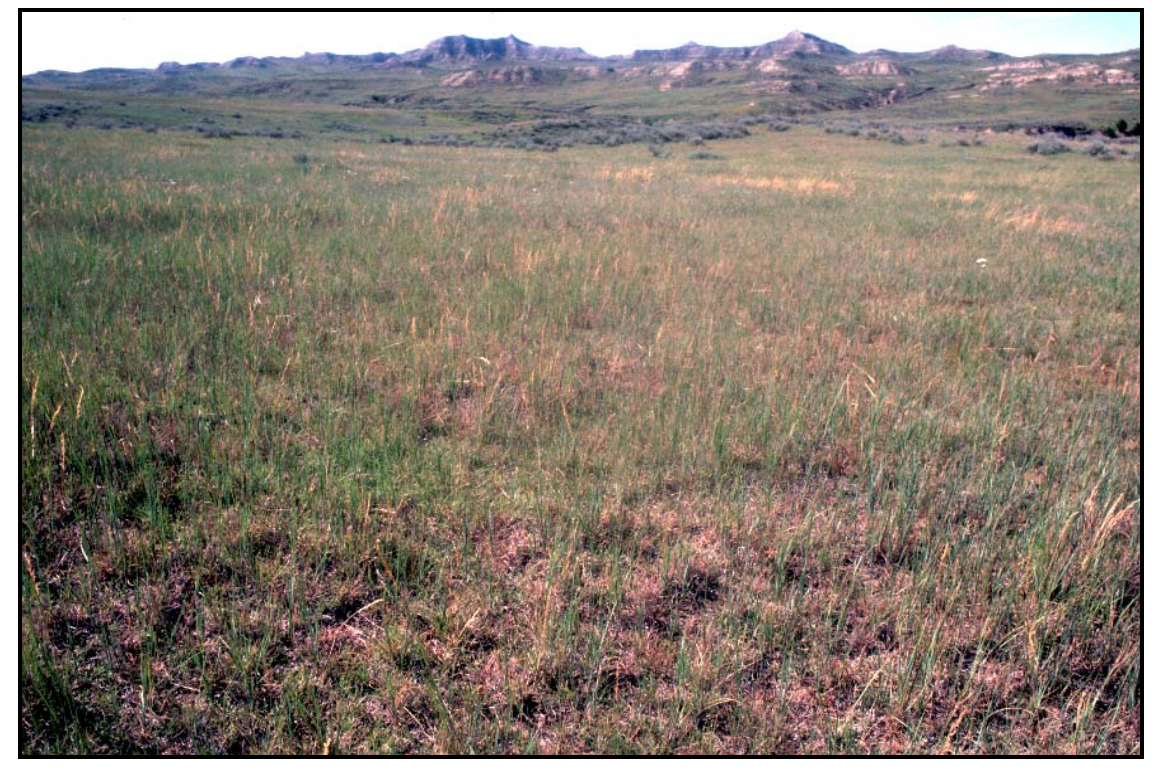

Photo by Bonnie Heidel

\section{Location}

The site lies 1 airmile southeast of Biddle, MT. The main access is via the Ranch Creek Road, going app. 8 miles east, and 3.5 miles south, then west 2 miles west on oil well roads, above Prairie Dog Creek.

\section{General Description}

The Biddle Hills are a series of dissected ridges and eroded site tributaries of the Little Powder River. Siltstone outcrops are consistently exposed at different levels, with some of the most extensive outcrops being on the knolls and spines that top the ridges. Grassland predominates, and grades into sagebrush steppe in steep upper slopes.

\section{Vegetation Communities}

The steppe community is dominated by (Artemisia tridentata ssp. wyomingensis) Wyoming bigsage with cover approaching 30\%. The understory is codominated by Pascopyrum smithii (western wheatgrass) at $30 \%$ and Buchloe dactyloides (buffalo grass) at 50\%. The only forb with more than trace cover is Achillea millefolium (common yarro). This community is recurrent over an area that covers about half a township.

The herbaceous grassland community is dominated by western wheatgrass (over $30 \%$ ) and buffalo grass (over 60\%). The most common forb is Agoseris glauca (pale false-dandelion), at slightly more than trace cover. This community is prevalent over an area that is about half a township.

\section{Environmental Characteristics}

The uplands are sharply dissected uplands by tributaries of the Little Powder River, with scattered ridge outcrops, and steppe on their upper, more sheltered slopes. The shrub communities grade into grassland with decreasing slope and lower topographic position, and into sparsely vegetated communities on exposed aspects. Soils are part of the Elso-Midway-Thurlo soil association with 8-35\% slope, and are some of the most uniform siltbeds in the area. 


\section{Significance}

This area supports the largest and most ecologically intact populations of Barr's milkvetch on BLM lands in Montana. The Wyoming big sage - western wheatgrass community ranges from good to excellent condition and the landscape is largely functionally intact from an ecological perspective. It was also the first site in the County where we documented buffalo grass as a co-dominant under essentially undisturbed conditions.

\section{Land Management}

The area is made up of several range allotments. It is bordered by oil wells on the east. A wide, new road traverses much of the site. 


\section{BIDDLE HILLS}

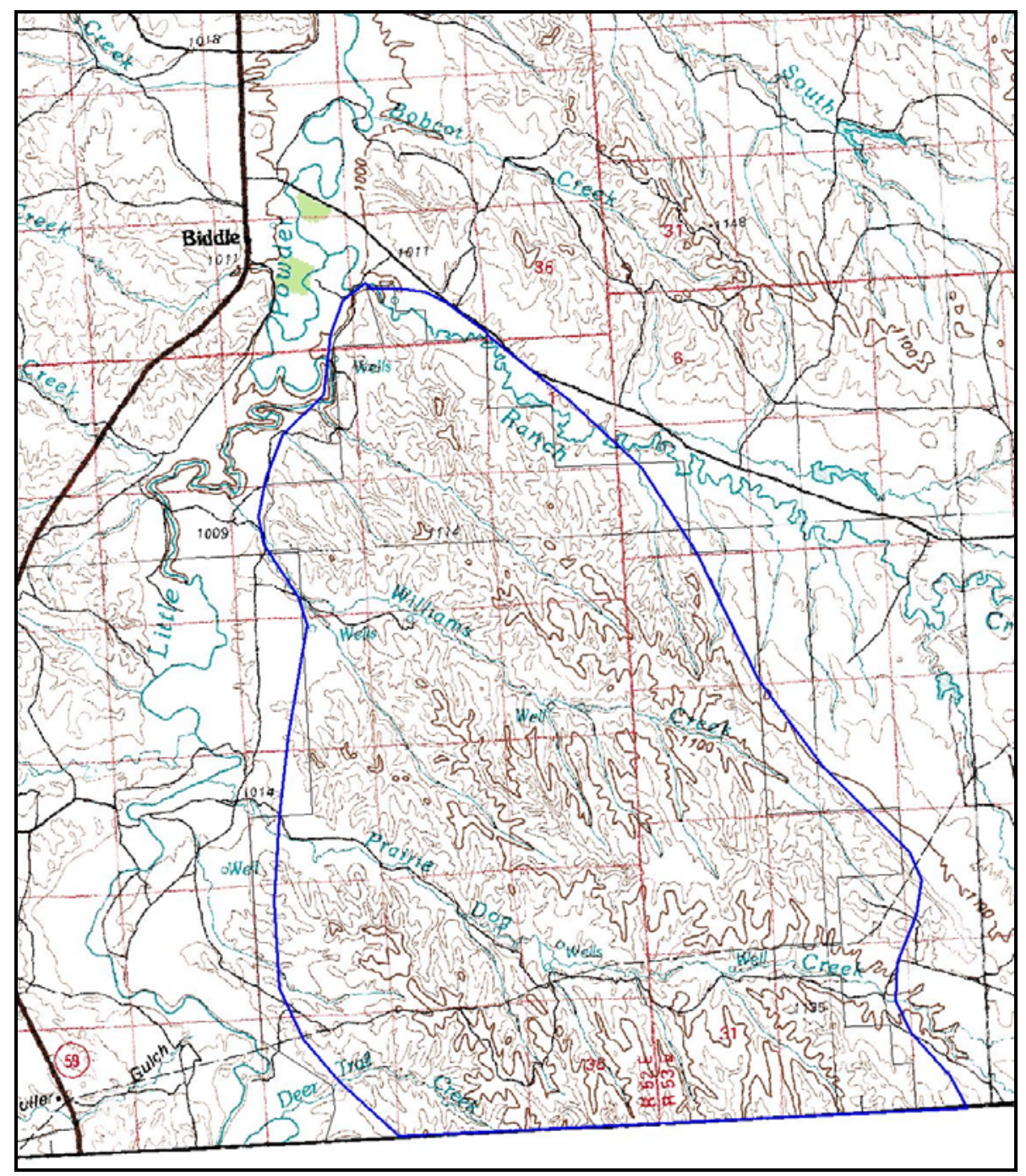




\section{Cabin Creek}

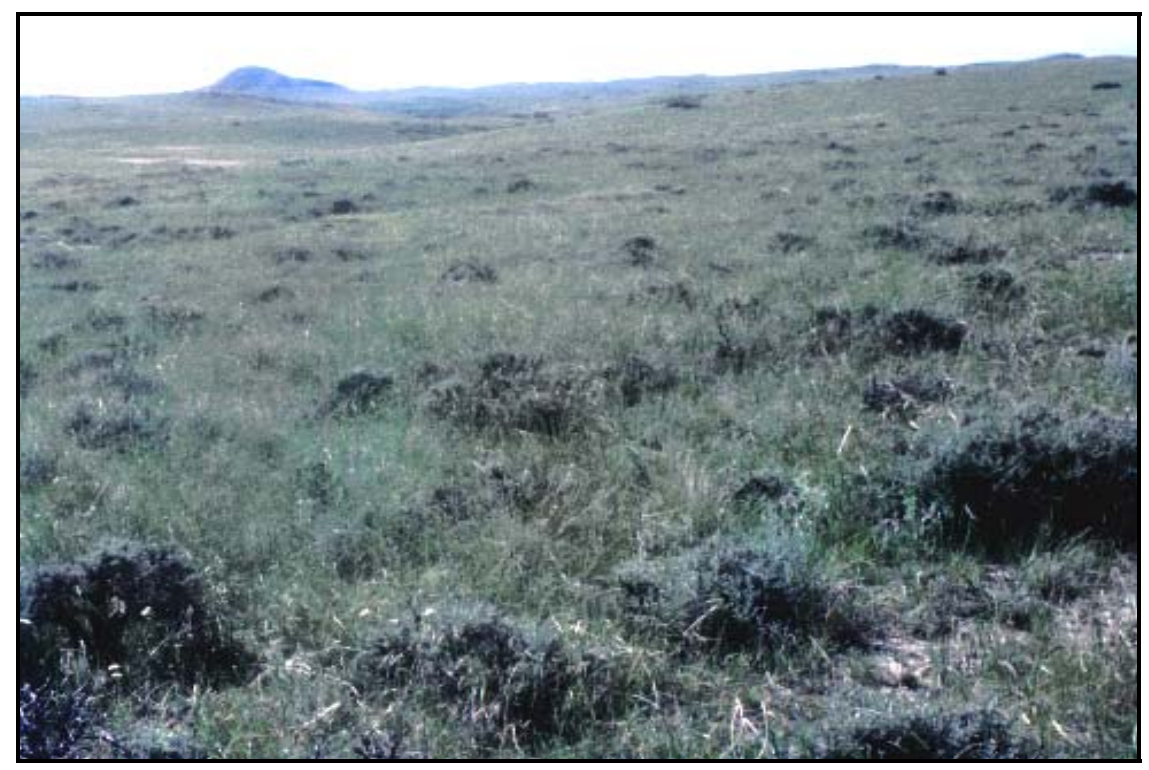

Photo by Bonnie Heidel

\section{Location}

Near the eastern edge of the county, along Cabin Creek, about 13 miles N of Boyes, MT, primarily NW of Moore Road.

\section{General Description}

This area is characterized by gently rolling upland plains and widely scattered drainages. Dominant vegetation is a diversity of grassland types, all with Hesperostipa comata (needle-and-thread). Large areas of Wyoming big sagebrush grassland are interjected on midslopes. The upper segments of well-drained sandy slopes along watercourses and ridges are co-dominated by Calamovilfa longifolia (prairie sandreed).

\section{Vegetation Communities}

This area supports two significant vegetation types. The grassland is a Calamovilfa longifolia -

Hesperostipa comata (prairie sandreed - needle-and-thread) community, both species with about $20 \%$ cover. Carex filifolia (thread-leaved sedge) and C. inops (sun sedge) are each present with about 10\% cover, and there is a diversity of forbs (27 species recorded), with only Ambrosia psilostachya (nakedspike ambrosia) abundant.

The shrub-herbaceous community on the midslopes is dominated by Artemesia tridentata ssp. wyomingensis (Wyoming bigsage), with cover over $10 \%$. The understory is co-dominated by Pascopyrum smithii (western wheatgrass) at 30\% cover and Buchloe dactyloides (buffalo grass) at $40 \%$ cover.

\section{Environmental Characteristics}

A range of sedimentary bedrock materials not apparent from the topography underlies the uplands and drainages. Soils are Remmit-Ocean Lake, with 8-25\% slopes and Arvada-Bone complex with 0-4\% slopes. 


\section{Significance}

The prairie sandreed - needle-and-thread association is a rare upland community that typically occurs in small patches on the landscape. The Wyoming big sagebrush - western wheatgrass - buffalo grass) community is a large-patch community occurring here in good condition in a landscape setting that is ecologically intact. This is one of the few areas in the county where this shrub-herbaceous community was found on clay substrate (Arvada-Bone complex), normally occurring on silt. 


\section{CABIN CREEK}

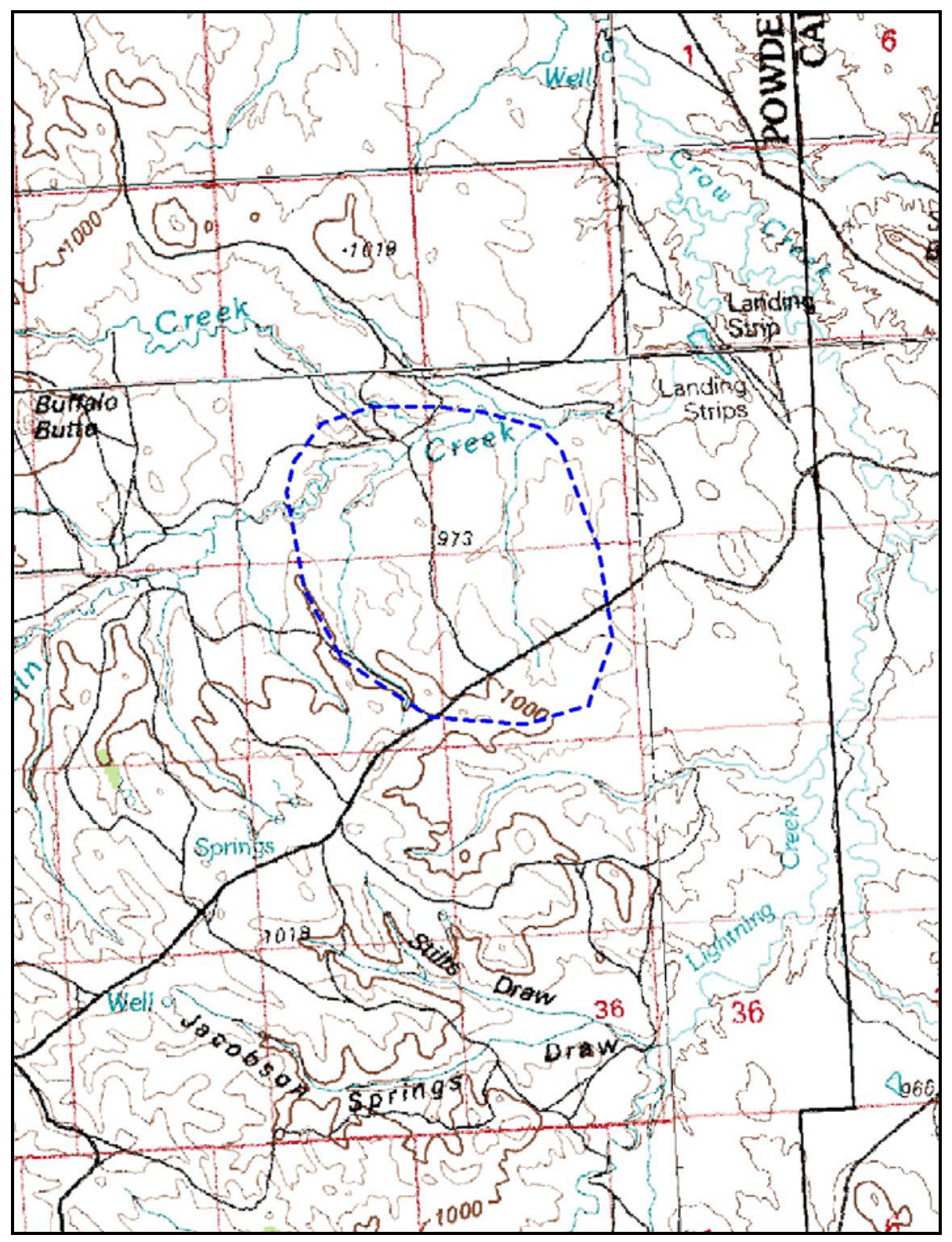

Appendix B-13 
Appendix C. Powder River County - Plant Species of Concern 


\section{Table of Contents}

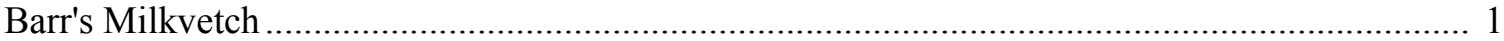

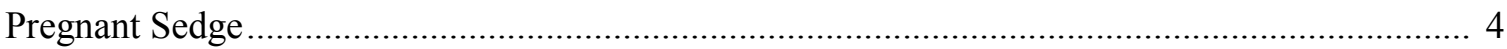

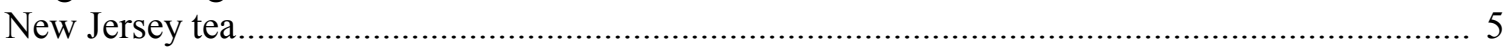

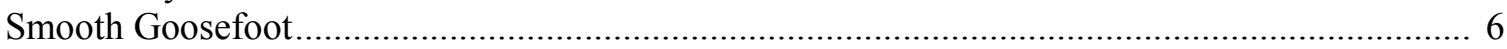

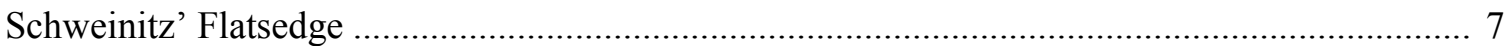

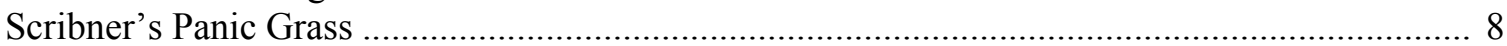

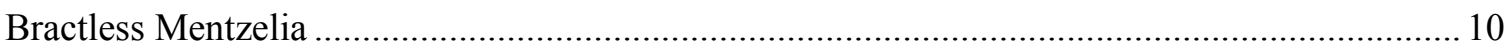

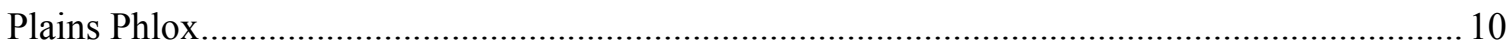

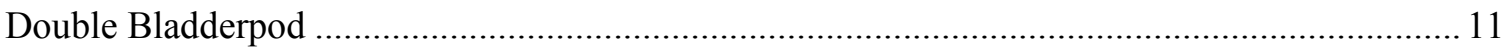

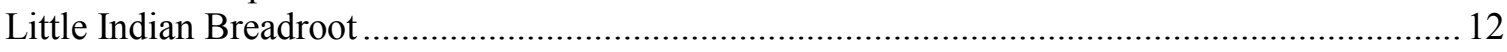

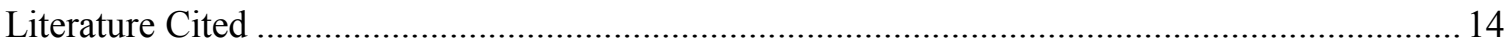

\section{Illustration and Photo Credits:}

Jeanne R. Janish

Debbie McNiel

John Challey

Joe Duft

Bonnie Heidel

Hollis Marriott

Steve Shelly

Dee Strickler

The New York Botanical Garden
Figure 20, 28 (From 'Vascular Plants of the Pacific Northwest')

Figure 1, 24, and 26

Figure 21

Figure 18

Figure 3-7, 9, 15, 16, 19, 22, 23, 25, 27, 29 and 30

Figure 11 and 12

Figure 8

Figure 2

Figure 10, 13, 14, and 17

Reprinted with permission from the New Britton and Brown Illustrated Flora of the

Northeastern United States and Adjacent Canada, Vol. 1, page 310, Copyright 1952, The New York

Botanical Garden 


\section{Astragalus barrii Barneby}

Barr's milkvetch

Bean Family (Fabaceae)

BLM status: Watch

USFS status: Sensitive

Global rank: G3, State rank: S3

State status summary: Barr's milkvetch is a regional endemic with more than 20 occurrences in Montana. It has no immediate threats but is potentially vulnerable to exotic species invasion through disturbances of fire and coalbed methane developments.

Description: Barr's milkvetch is a perennial that grows in low, dense mats. Leaves have 3 narrowly lance-shaped leaflets 1 to $4 \mathrm{~cm}$ long and densely covered with short white hairs (Figures 1 and 2). Stipules at the leaf bases are membranous. Purple or pinkish-purple pea shaped flowers are borne in a narrow, open, and few-flowered inflorescence

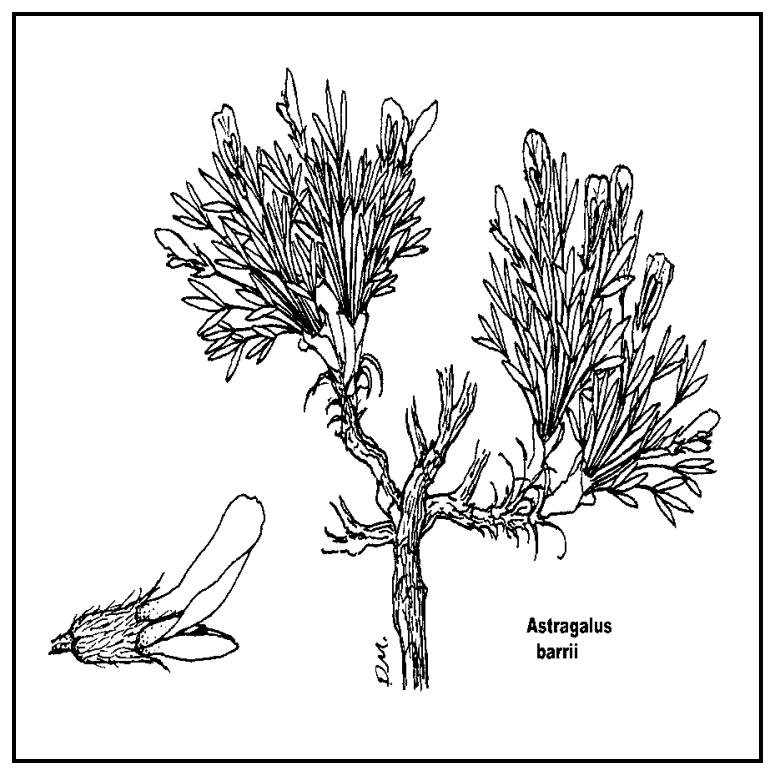

Figure 1. Illustration of Astragalus barrii

(Figure 3). The petals are 7 to $17 \mathrm{~mm}$ long. The calyx is 3 to $5 \mathrm{~mm}$ long and densely covered with long, white hairs. The sparsely white, hairy pod is narrowly elliptical, 4-8 $\mathrm{mm}$ long, and 1 to $2 \mathrm{~mm}$ in diameter. Flowering occurs in May-early June and fruiting from late May-June.

The only other mat-forming species with 3-leaflets in the range of Astragalus barrii in Montana are
Astragalus gilviflorus and Astragalus hyalinus. Both have white flowers and a longer calyx tube (6 to $16 \mathrm{~mm}$ ) than the Astragalus barrii calyx tube length ( 2.8 to $5 \mathrm{~mm})$. They also have peduncles that are short $(<3.5 \mathrm{~mm})$ or absent compared to Astragalus barrii peduncle length ( 7 to $24 \mathrm{~mm}$ ).

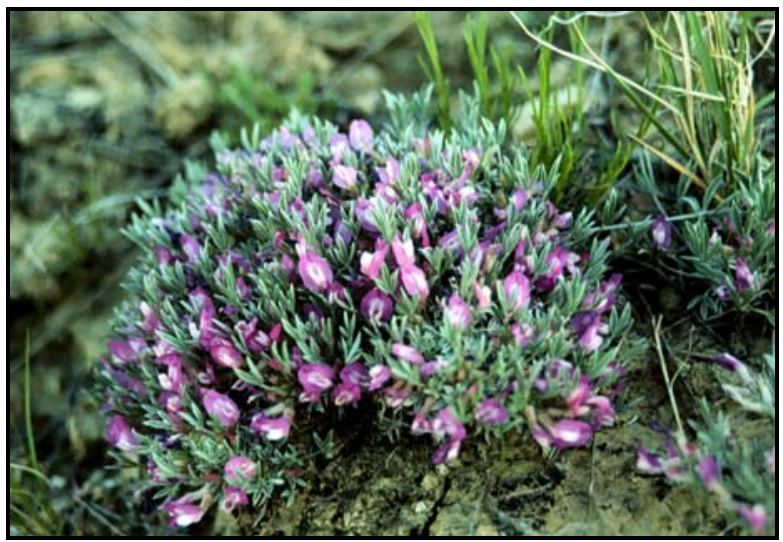

Figure 2. Photograph of Astragalus barrii

Distribution: Barr's milkvetch is a regional endemic found at the junctions of northwestern South Dakota, northeastern Wyoming, and southeastern Montana. In Montana it has been collected from four counties, but one of these represents a single historic record that has not been relocated. Besides the historic Carter County record, there are a total of 35 other records for the species. Half of these (18) are in two areas of concentration and may represent two large population complexes.

Both of the large concentrations of Astragalus barrii are in Powder River County, which has a total of 23 known records for the species. As mentioned above, 18 of these in the County are highly concentrated and may represent two large population complexes along part of Otter Creek and the Little Powder River. In visits to the latter, we determined that the species repeats consistently in the landscape where suitable habitat is extensive so that some of these records are very large. We also began documenting intervening records that connect the concentrations of 18 records.

Astragalus barrii has the highest number of records among the Montana species of concern in the study area, and is the only one that has a geographically In a few cases, the gentler terrain of the Midway- 


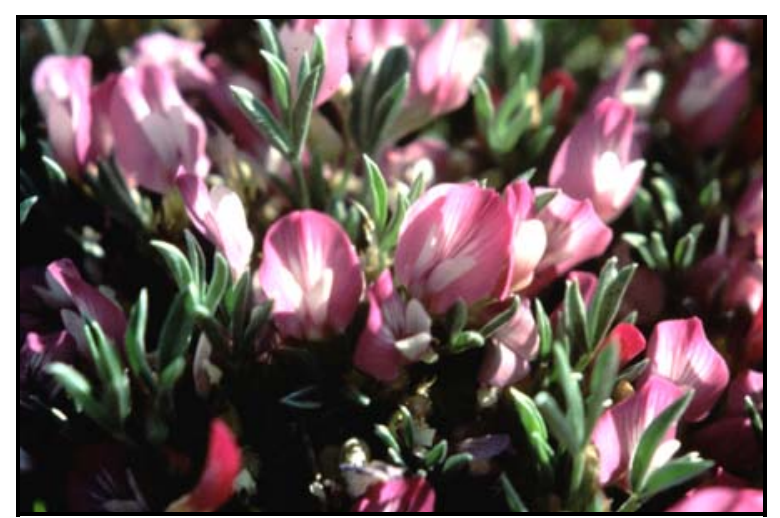

Figure 3. Photograph of Astragalus barrii (close-up)

limited distribution beyond state borders. We represent its distribution in the county by a separate symbol in the map showing locations of plant species of special concern in Powder River County County (see the map labeled Figure 11 in the body of the report).

Note: In the course of this study, we determined that Astragalus hyalinus is much more widely distributed than previously known in the western and southern parts of the County. It cannot be distinguished vegetatively from Astragalus barrii, but has a white or cream-colored flower that readily distinguishes it during flowering (Figure 4). All new records of Astragalus barrii were verified using flowering material. They also differ in their habitat, with Astragalus hyalinus restricted to settings with sandstone outcrop. We note that Astragalus barrii superficially looks like the common Astragalus spathulatus, but the latter has

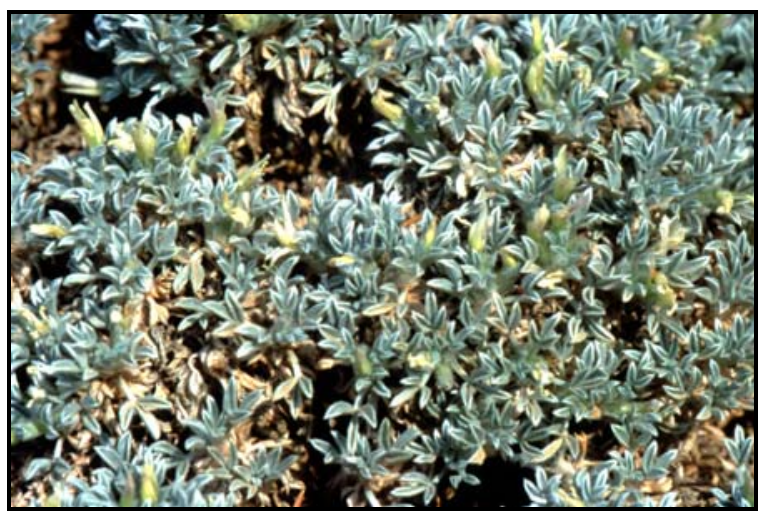

Figure 4. Photograph of Astragalus hyalinus (note white flowers) an elongated flowering stalk (Figure 5). A complete set of technical distinguishing characteristics between Astragalus barrii and Astragalus hyalinus is summarized in Heidel and Marriott (1996).

Habitats: Barr's Milkvetch is restricted to sparsely vegetated knolls, buttes, and barren hilltops, on calcareous soft shale and siltstone. It is often found at the rim of outcrops and midslope benches (Figure 6). These microhabitat settings represent thin silty ecological sites. Their clay fraction is high enough in places to classify the microhabitats as thin clayey. There is little or no soil profile development but there are generally no restrictive layers that would classify the microhabitats as a shallow ecological site. These microhabitats occur within predominantly silty ecological sites, but while they occupy a small fraction of the landscape, they are widespread and recurrent in part of BLM-administered lands (Figures 7 and 8).

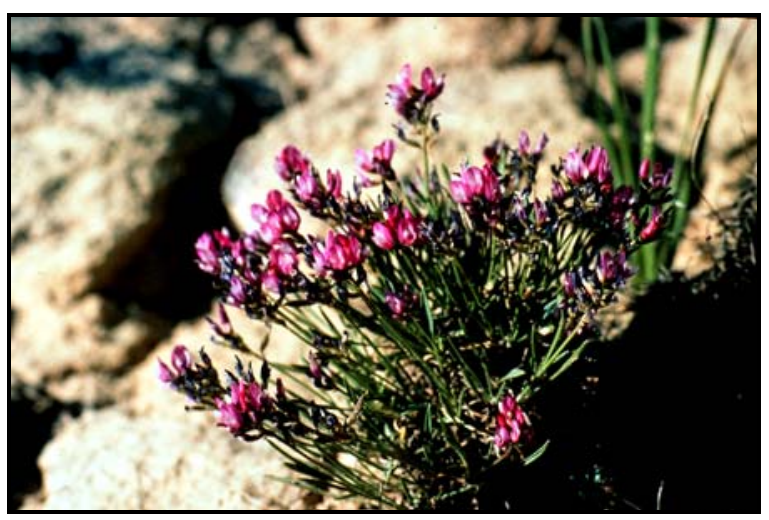

Figure 5. Photograph of Astragalus spathulatus (note stalked flowers)

This species is restricted to upper-and mid-slope topographic positions and does not occupy outwash or eroded gullies below the outcrops. It is most commonly found on slopes with northern and eastern aspects and does not occur on steep southfacing slopes with their salt-affected vegetation. In other words, its habitat represents a small subset of outcrop settings and a small subset of the thin silty ecological site.

In Powder River County, Barr's Milkvetch is found, almost without exception, on the MidwayElso rocky soils on 35\% to 70\% slope (Parker et al. 1971). 
Elso rocky soils ( $8 \%$ to $35 \%)$ is the mapping unit. Soil textures range from silty clay to loam, and are frequently uniform silt loam. The soil surface is often uniform silt but may have a veneer or be embedded with pebbles and cobbles.

The Little

Powder River

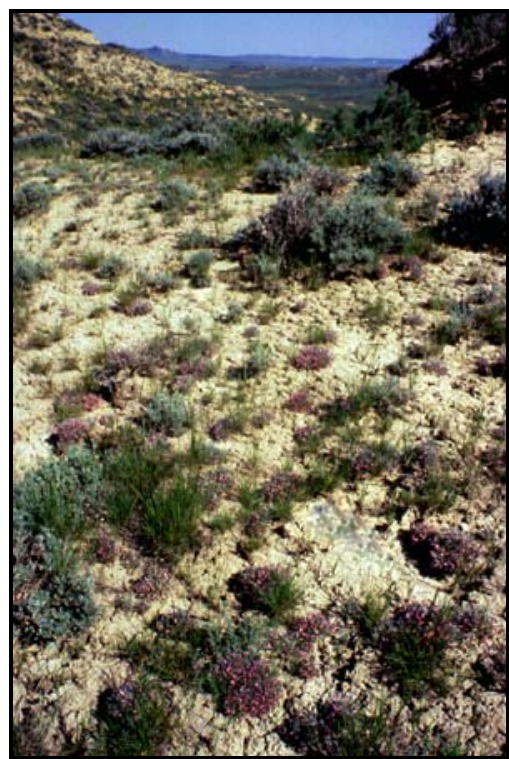

Figure 6. Habitat of Astragalus barrii habitat is on the open plains while the Otter Creek habitat is in a pineland setting, but they otherwise have similar species composition. The sparse vegetation has many of the same species present from place to place even if the relative cover of any one of them is variable. The most common shrub is usually Wyoming big sagebrush (Artemisia tridentata wyomingensis). The most common grass that we noted on BLM lands is western wheatgrass (Pascopyrum smithii) or else thickspike wheatgrass (Elymus lanceolatus) on level terrain, but neither is mentioned among the associated species on Custer National Forest (Schassberger 1988, 1990). Other directlyassociated species typically include leafy musineon

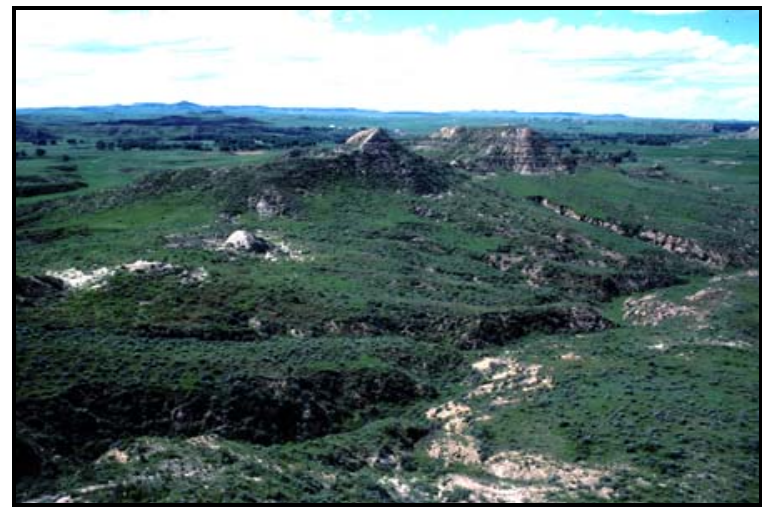

Figure 7. Landscape of Astragalus barrii habitat
(Musineon divaricatum), broom snakeweed (Gutierrezia sarothrae), few-flowered buckwheat (Eriogonum pauciflorum), textile onion (Allium textile), cushion goldenweed (Haplopappus acaulis, $\mathrm{x}$ goldenweed (Haplopappus armerioides), and (Hymenoxys richardsonii). There are species that have been characterized as part of associated vegetation in past reports and as part of the information recorded for individual records, however, they are actually found on adjoining sandstone substrates rather than soft shale with Astragalus barrii. Plants such as little bluestem (Andropogon scoparius) and soapweed (Yucca glauca) do not generally occupy the same microhabitats as Astragalus barrii while they may be common and conspicuous all around it.

Comments: The species almost always occurs in habitats considered secondary range, in addition, the plant is not grazed due to its low growth form. It is little-affected by allotment management practices and developments unless concentrated livestock trampling occurs in its habitat.

Astragalus barrii is potentially vulnerable to exotic species encroachment. It is an earlysuccession species and its forested habitat settings may be subject to increased tree canopy cover. Any revegetation efforts should avoid seeding sweetclover (Melilotus spp.) in proximity. There is little encroachment by

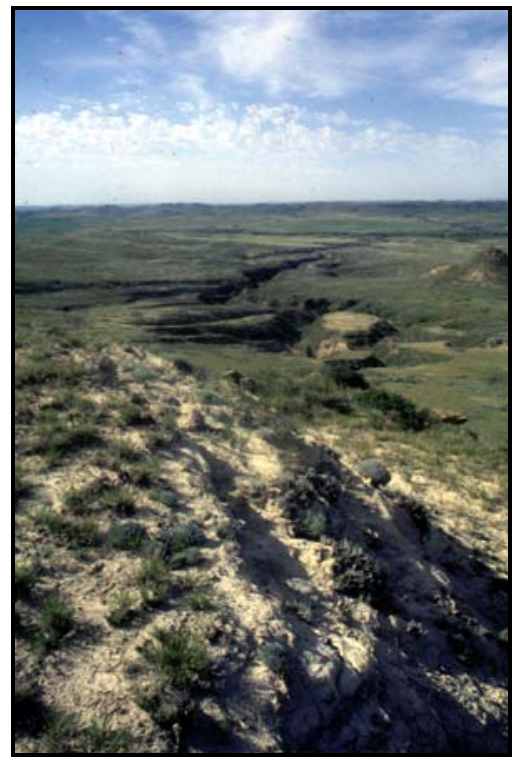

Figure 8. Habitat of Astragalus barrii above Horse Creek weedy annuals at present. The fine texture and instability of the soils limit invasion by annual bromes. A non-native mustard, malcolmia (Malacolmia africana), is in early stages of invading fine-textured slopes of Powder River County and elsewhere. It appears to be spreading along backroads. 
Carex gravida Tuckerm. var. gravida

Pregnant sedge

Rush Family (Cyperaceae)

BLM status: Watch

USFS status: Sensitive

Global rank: G5T5?, State rank: S1

State status summary: Pregnant sedge is known from fewer than six occurrences. Its habitat is in primary range that is potentially affected by grazing and logging.

Descriptions: Pregnant sedge is a perennial grasslike plant that forms clumps of stems that reach up to $6 \mathrm{dm}$ high and arise from short root stocks.

Leaves are 4 to $8 \mathrm{~mm}$ wide and clustered near the base of the plant. Flowers are clustered in eggshaped spikes that are about $1 \mathrm{~cm}$ long; the female flowers (perigynia) occupy most of the spike, but there are a few male flowers at the tip (Figures 9 and 10). Spikes are aggregated at the top of the stem and subtended by 2 to 3 leaf-like bracts that are shorter than the inflorescence. Scales subtending each perigynia are oval with a long point at the tip. The perigynia are 4 to $5 \mathrm{~mm}$ long and egg-shaped; they gradually taper into a beak that is serrate on the edges and notched at the tip. There are few or no nerves visible on the outer face of the perigynia. There are 2 stigmas, and the seed is 2-sided. Fruit matures in late June-July.

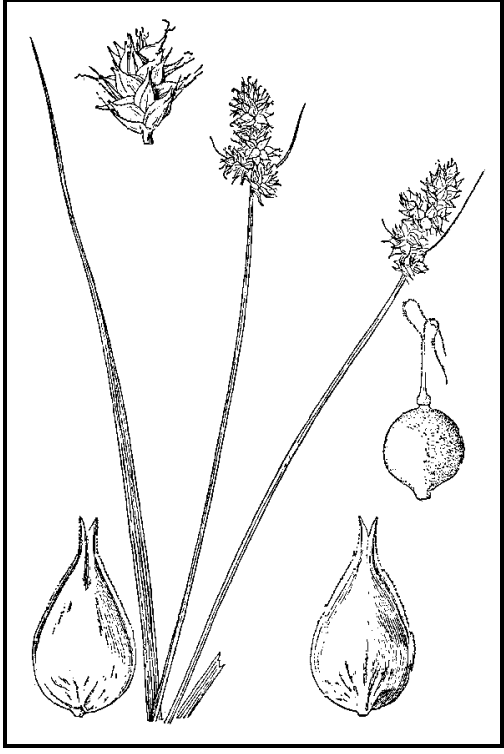

Figure 9. Illustration of Carex gravida var. gravida
Carex is a large and difficult genus; there are many species similar to Carex gravida. The awntipped scales of the perigynia, relatively broad leaf blades (greater than 3.5 $\mathrm{mm}$ ) and loose sheath help distinguish it from the closely-related Carex hoodii with which it overlaps in distribution. A hand lens or microscope and technical key are essential for positive determination.

Distribution: Pregnant sedge is an eastern species that is peripheral in Montana, extending from Saskatchewan to Pennsylvania, south to New Mexico, Texas, Missouri and Virginia. In Montana, it is known from only three southeastern

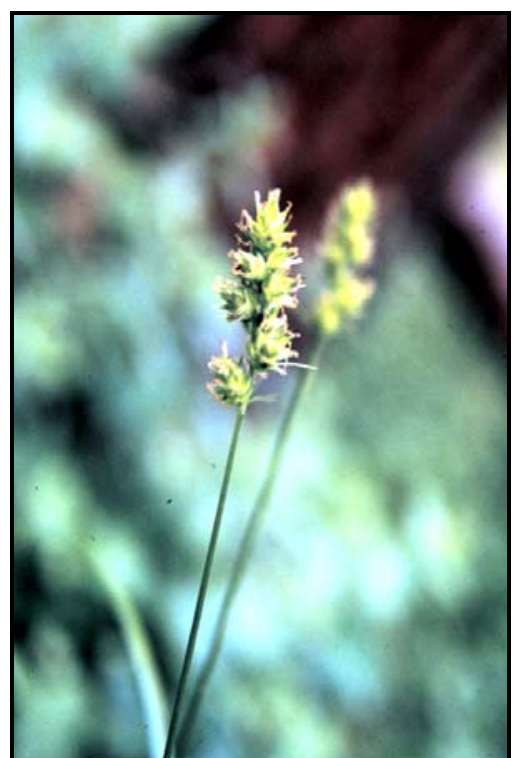

Figure 10. Photograph of Carex gravida var. gravida (close-up) counties, including Big Horn, Powder River and Rosebud counties. It has only been found in two places on the Ashland District of the Custer National Forest (Heidel and Marriott 1996), and these represent the known Powder River and Rosebud records. In the course of this survey there was very little suitable habitat in the areas that were visited, so it was not found and no additional data was collected on this species and its distribution.

Habitat: This species is restricted to open woods on the plains, often in ravines with deciduous trees in a setting that is with or without flowing water. The ravines border overflow ecological sites. In the Ashland District, the species occurs along ravine bottoms dominated by a combination of green ash and chokecherry (Fraxinus pennsylvanica / Prunus virginiana) within pine woodland (Figure 11). In some cases, aspen (Populus tremuloides) is present. Other associated species include serviceberry (Amelanchier alnifolia), Hood's sedge (Carex hoodii), Torrey's sedge (Carex torreyi) and Sprengel's sedge (Carex sprengelii), and other plants of eastern deciduous woodland.

Comments: This species seems restricted to mesic microhabitats within pine woodland, making it particularly vulnerable to changes in pine woodland structure and composition as affected by 
grazing and logging. These settings are vulnerable to invasion of exotic species like Kentucky bluegrass (Poa pratensis).

There were fire scars among the Ponderosa pine (Pinus ponderosa) at one of the Ashland District sites where the species was found suggesting the plant can survive ground fire.

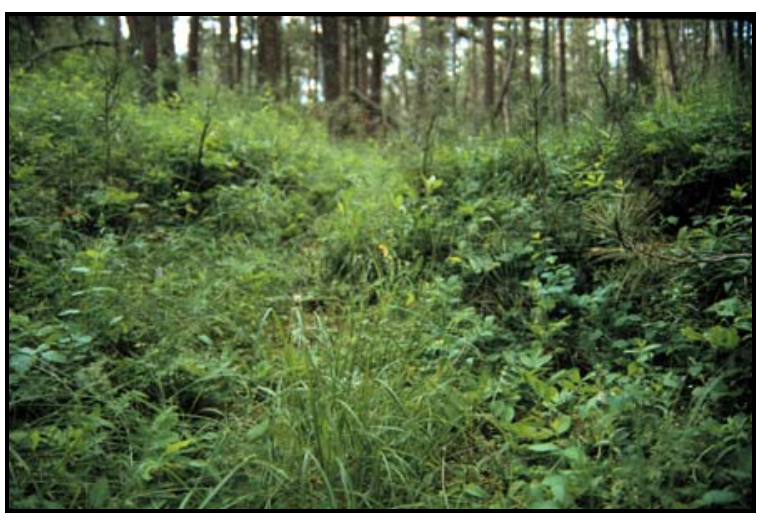

Figure 11. Habitat of Carex gravida var. gravida (Custer Natl. Forest).

\section{Ceanothus herbaceus Raf.}

New Jersey tea

Buckthorn Family (Rhamnaceae)

BLM status: Watch

USFS status: -

Global rank: G5T?, State rank: SH

State status summary: New Jersey tea is known from one historic occurrence in Montana. It may be declining elsewhere on the Great Plains.

Relocation efforts have not been successful to date.

Description: New Jersey tea is a highly branched shrub with stems up to $1 \mathrm{~m}$ high. The alternate, lance-shaped to narrowly elliptic leaves are 2 to 6 $\mathrm{cm}$ long and have serrated edges; they are glabrous on top but hairy beneath. Numerous white flowers are born in congested, rounded inflorescences that terminate the growing branches (Figures 12 and 13.) Each flower is about 2 to $3 \mathrm{~mm}$ high with 5 calyx lobes and 5 petals that have a linear basal portion and a hood-shaped blade. There are 5 stamens and a 3-lobed ovary. The fruit is a glossy, brown, 3-lobed, globose capsule that is 3 to $5 \mathrm{~mm}$ wide. It flowers in June.

The Ceanothus genus has simple alternate leaves with 3 prominent, somewhat parallel veins arising from nearly the same point near the base of the blade. It also has hoodshaped petals, and 3-lobed fruits. Ceanothus herbaceous can be distinguished from other members of the genus by its narrower leaves, which are less than $2 \mathrm{~cm}$ wide and not shiny on the upper surface.

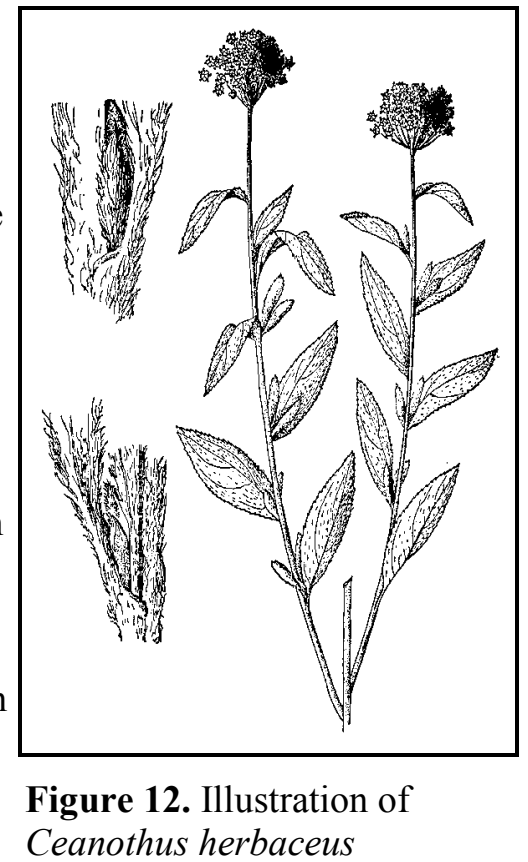

Distribution: New Jersey tea is an eastern species that is peripheral in Montana. It grows from Quebec to Manitoba to eastern Montana, and south to Georgia, Texas, and Colorado. In Montana, the plant is known from a historic record in Powder River County.

There are few pine stands represented on BLM lands in the study area. Of the few that were visited

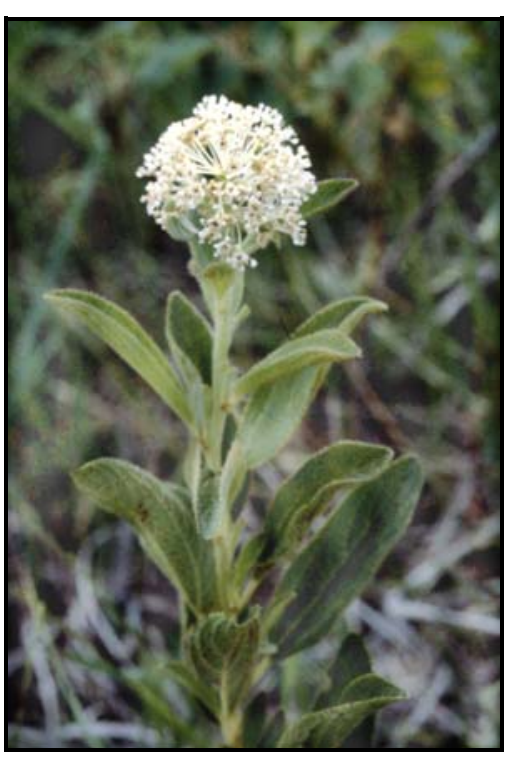

Figure 13. Photograph of Ceanothus herbaceus in the course of this survey, none appeared to have suitable microhabitat. It is not known whether this species is restricted to pineland habitat in Montana, and this species was also sought in the closest grassland habitat on BLM lands. No additional data were collected on this species and its distribution. 
Habitat: The single collection label for this species in Montana described the setting as a "grassy, pinecovered hill." It may represent a sandy, stony, or gravel ecological site. In the Great Plains, this species occupies rocky prairie hillsides, roadsides and open pine forests.

Comments: Management considerations are unknown. This species has diminished elsewhere on the Great Plains (Ode, pers. comm.) Some species of Ceanothus are highly palatable to wildlife and livestock.

\section{Chenopodium subglabrum (S. Wats.)}

\section{A. Nels.}

Smooth goosefoot

Goosefoot Family (Chenopodiaceae)

BLM status: Watch

USFS status: -

Global rank: G3G4, State rank: S1

State status summary: Smooth goosefoot is known from fewer than six occurrences in Montana, one of which may be extirpated. It occupies early-succession habitat that is potentially affected by grazing, changes to river flow regimes, and noxious weeds.

Descriptions: Smooth goosefoot is an annual with erect, simple, or high stems (2 to 3 ) $8 \mathrm{~cm}$ (Figure

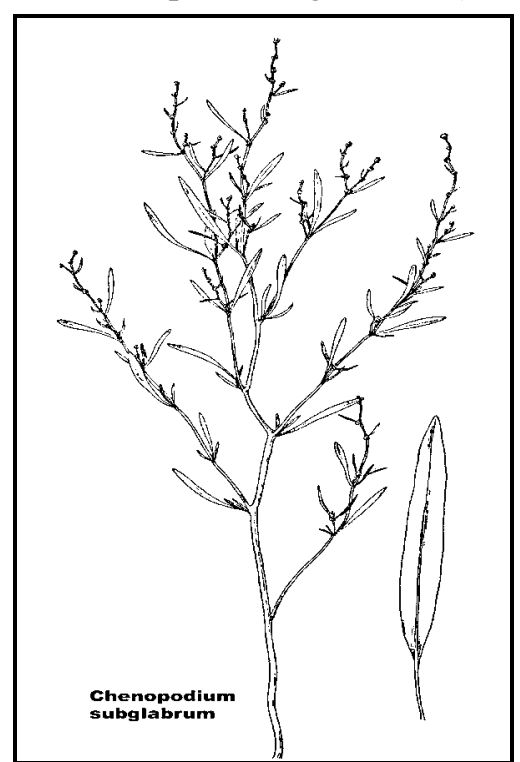

Figure 14. Illustration of Chenopodium subglabrum
14). The alternate leaves are linear with entire margins, single veined, glabrous, up to $3 \mathrm{~cm}$ long. The small, green flowers are grouped in remote clusters in simple or branched spikes (Figure 15). Each flower lacks petals but has 5 glabrous sepals and 5 stamens. The one seeded fruit is compressed hemispherically and is relatively large; 1 to $2 \mathrm{~mm}$ across, exposing a jet-black fruit at maturity that readily separates from the pericarp (fruit wall). Fruiting occurs in late June-July.

\section{Chenopodium} subglabrum sometimes occurs with and is related to Chenopodium leptophyllum. They both have linear, singleveined leaves but

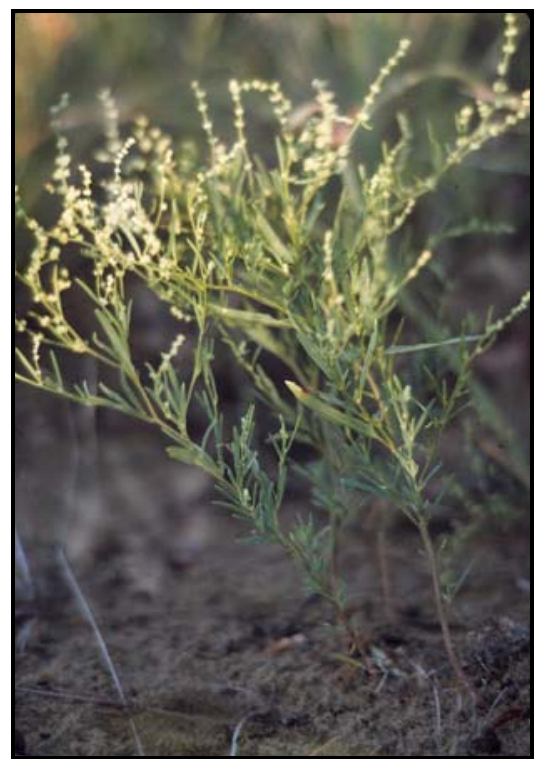

Figure 15. Photograph of Chenopodium subglabrum the latter are farinose white (mealy usually whitish colored). Chenopodium leptophyllum also has denselyclustered flowers, a relatively unbranched growth form, fruits usually $1 \mathrm{~mm}$ or smaller, and seeds which do not detach from the pericarp.

Distribution: This species is known from the Great Plains, extending from Manitoba to Alberta, and south to Kansas and Nevada. It is also in the Midwest, including Michigan and Missouri. Plants of the Pacific Northwest, including Washington, Idaho and Oregon, are said to differ from Great Plains material (Crawford 1973) and their proper disposition has not been resolved. It is centered in the Nebraska Sandhills and widely scattered in five eastern Montana counties.

The species was documented in Powder River County and on BLM-administered lands for the first time during this study, where it was found in the northeastern corner of the County.

Habitat: Chenopodium subglabrum occupies two main kinds of settings, namely sparsely vegetated sand dunes and sandy terraces of major rivers on the plains. Only one of the five Montana records, located in Custer County, was from a riparian setting on the Tongue River. All five records represent sandy ecological sites. This species is a 
poor competitor and is associated with other annuals and early-succession species.

The Powder River County setting is an isolated ridgetop blowout rather than a sand dune (Figure 16). This is a different setting than has been found to date, and may mean that the species is not so narrow in its habitat requirements as previously interpreted. It was restricted to one segment of the blowout rim where sand was being deposited, in association with lemon scurfpea (Psoralea lanceolata), sandhills bluestem (Andropogon hallii) and western spiderwort (Tradescantia occidentalis). While there were no other nearby ridgetops with blowout features, the Midway Rock land association and the sandy ecological site that it represents are widespread (Parker et al. 1971). They are associated with many other landforms capped by sandstone.

The were no records of Chenopodium subglabrum documented in the few riparian settings we surveyed where we had access along the Powder River.

Comments: Maintenance of early seral habitat in the upland settings requires a balance of fire and/or grazing. Maintenance of early seral habitat in the riparian setting requires intact flow regimes and landscape processes over a larger scale. Tamarisk control is needed in riparian habitat, and leafy spurge is at early stages of invading some of the most extensive upland habitat.

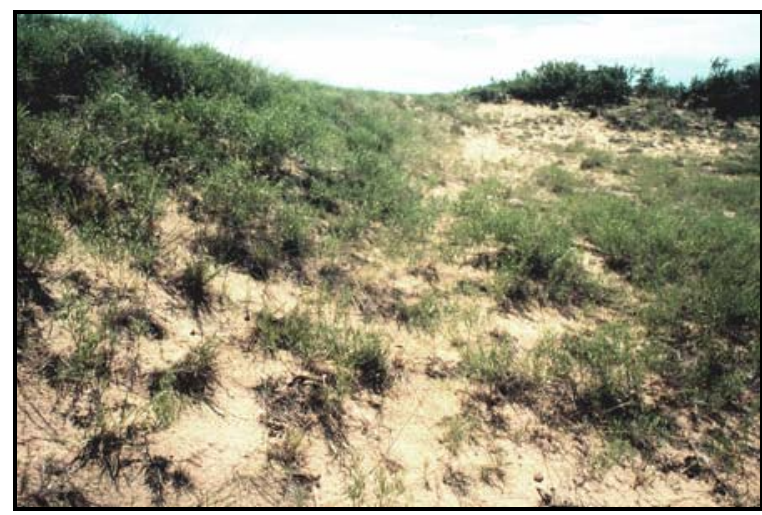

Figure 16. Habitat of Chenopodium subglabrum (Medicine Rocks SP)
The Powder River population occurs in secondary range, where livestock use is light and water sources are remote.

\section{Cyperus schweinitzii Torr.}

Schweinitz' flatsedge

Rush Family (Cyperaceae)

BLM status: Watch

USFS status: -

Global rank: G5, State rank: S2

State status summary: Schweinitz' flatsedge is known from 6 to 20 occurrences, most of which have low numbers. It is an early-succession species, affected by absence or excess of disturbance and potentially threatened by noxious weeds.

\section{Description:}

Schweinitz'

flatsedge is a grass-like perennial with stems that are 10 to $40 \mathrm{~cm}$ high, arising from short, irregularly swollen rhizomes (Figure 17). The leaves are 1 to 4 mm wide and located mostly near the base of the plant. The inflorescence is subtended by 3 to 6 long, leaf-like

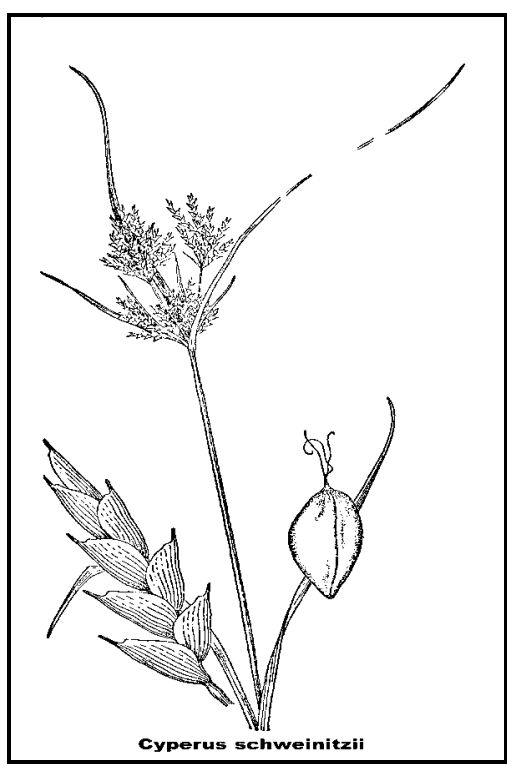

Figure 17. Illustration of Cyperus schweinitzii bracts, some of which are wider than the leaves (Figure 18). The inflorescence is made up of ascending clusters of flattened spikelets that are 5 to $25 \mathrm{~mm}$ long and borne on stalks that are very short to long. The flowers are crowded opposite each other and consist only of a small, pointed scale, which is about 3 to $4 \mathrm{~mm}$ long and subtends 3 stamens and an ovary. The seed is triangular in cross-section. Fruit mature in late June-July.

This is our only perennial Cyperus and is the only one occurring in upland habitat. 
Distribution: This species occurs from Alberta to Quebec and south to New Mexico and West Virginia. It is concentrated around the Great Lakes and the Great Plains. It is known from five counties in eastern Montana.

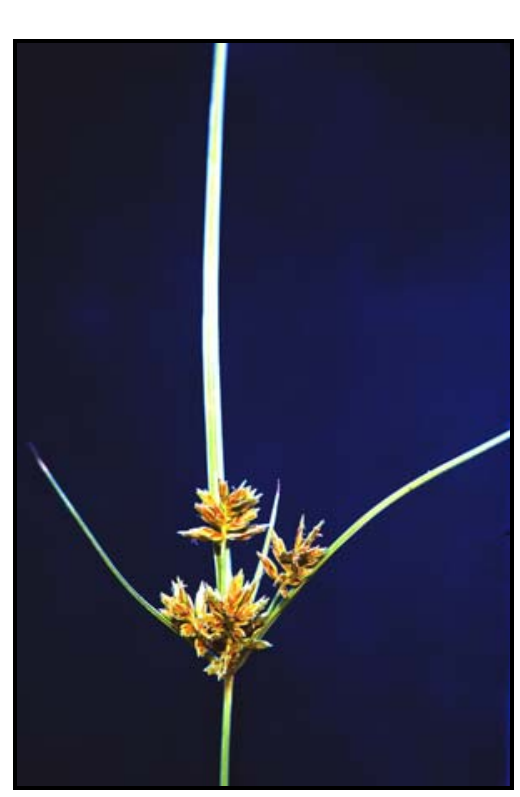

This species was documented for the first time in Powder River County at two sites in the northeastern corner.

Habitat: In the Great Plains, it is restricted to sparsely vegetated loose sand, most often associated with sand dunes. A typical sand dune blowout is shown in Figure

Figure 18. Photograph of Cyperus schweinitzii (close-up)

19. It occupies sandy ecological sites.

The Powder River County settings represent small blowouts at toeslope positions where there is loose sand eroded from sandstone outcrops above. This is a different setting than has been found to date, and may mean that the species is not so narrow in its habitat requirements as previously interpreted. It was more common in the setting where there was more wind erosions. Associated species included prairie sandreed (Calamovilfa longifolia), threadleaved sedge (Carex filifolia), and western spiderwort (Tradescantia occidentalis). While this species often overlaps with Chenopodium subglabrum (discussed previously), and is found in a wider range of successional conditions, it was not found in the same habitats in this study.

While there were no other nearby blowout features along Cedar and Stump creeks, the Elso-Ocean Lake association and the sandy ecological range site that this landscape represents are widespread (Parker et al. 1971).
Comments: Maintenance of the species' earlysuccession habitat requires balances involving grazing and/or fire. The species may decline in the absence or excess of these. Leafy spurge is in early stages of invading some of its most extensive habitat in the state.

The Powder River populations occur in primary range, and they are sufficiently far from Cedar and Stump creeks that the range is in good-excellent condition. There are no associated management concerns.

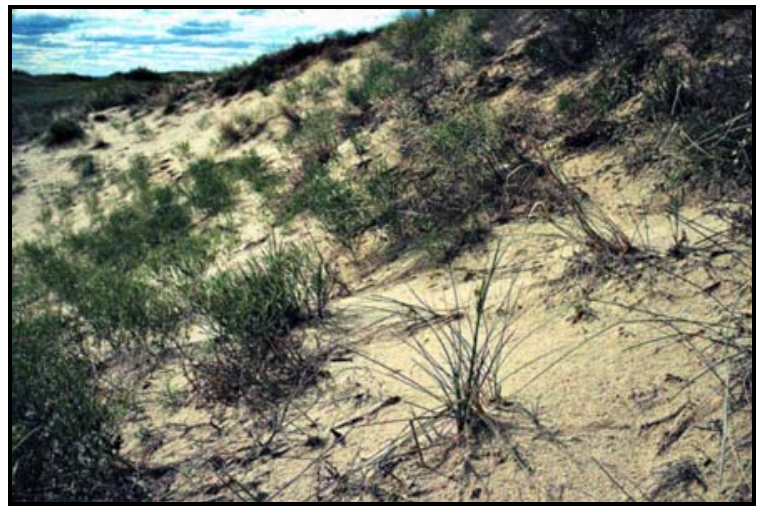

Figure 19. Habitat of Cyperus schweinitzii (Sheridan Co.)

Dichanthelium oligosanthes (J. A. Schultes) Gould var. scribnerianum (Nash) Gould

Scribner's panic grass

Grass Family (Poaceae)

BLM status: Watch. This species is not known from BLM-administered lands in Montana and is recommended for dropping accordingly.

USFS status:

Global rank: G5T5, State rank: S1

State status summary: Scribner's panic grass is known from fewer than six occurrences. Most have low population numbers and one represents a historic record. It is potentially affected by grazing and logging.

Description: Scribner's panic grass is a perennial that forms clumps of simple or branched stems 1 to $6 \mathrm{dm}$ tall (Figure 20). The lower leaves are 3 to 10 $\mathrm{cm}$ long and 3 to $12 \mathrm{~mm}$ wide, while the upper 


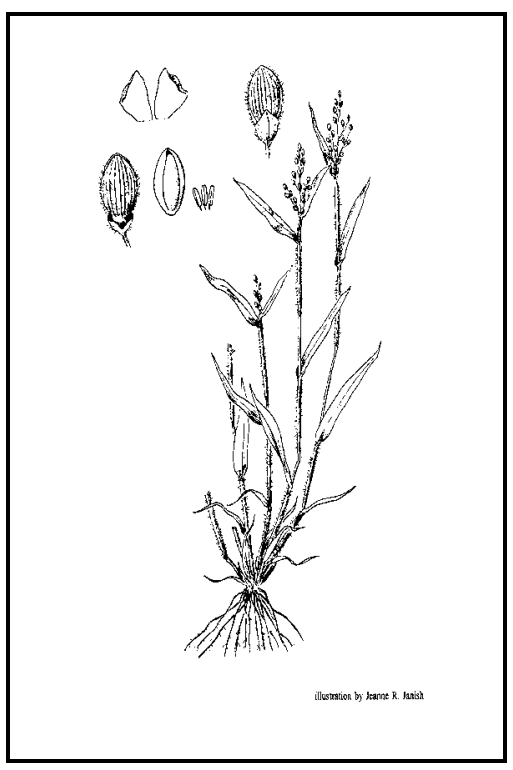

Figure 20. Illustration of Dichanthedlium oligosanthes var. scribnerianum leaves are short and relatively broad. Leaves are mostly glabrous, but the sheaths surrounding the stem are glabrous to long-hairy. There is a short fringe of hairs on the leaf where it meets the stem, which is known as a ligule. The flowers are borne on short-to longstalks, which are arranged in a conical inflorescence that is 3 to $8 \mathrm{~cm}$ high (Figure 21).

Inflorescences of the main stems are larger than those of the branches. Each egg-shaped spikelet has one flower, is about $3 \mathrm{~mm}$ long, and consists of two glumes enclosing a lemma and a palea that may or may not be hairy. Fruit matures in late June - early July.

The relatively large, egg-shaped, single-flowered spikelets help identify this as Dichanthelium. This species branches mainly in the upper portions of the stem, while Dichanthelium wilcoxianum usually branches near the base. A hand lens or microscope and technical key are needed for positive determination.

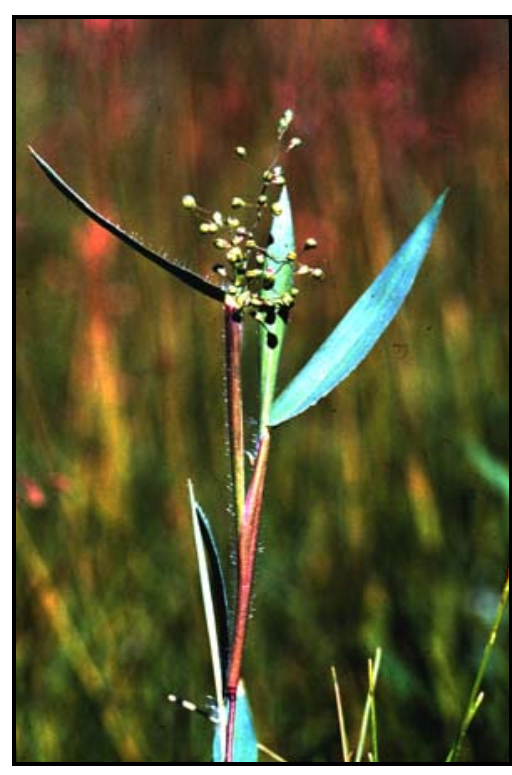

Figure 21. Photograph of Dichanthelium oligosanthes var. scribnerianum

Distribution: This species is widespread in the

eastern United States, extending from southern Canada to Mexico. It is peripheral in Montana, where it is known from both the Flathead Valley and from four records in Powder River County. The latter are all on the Ashland District of Custer National Forest.

Habitat: In Montana, this species is only known from open ponderosa pine woodlands of valleys and plains (Figure 22). These woodlands fall

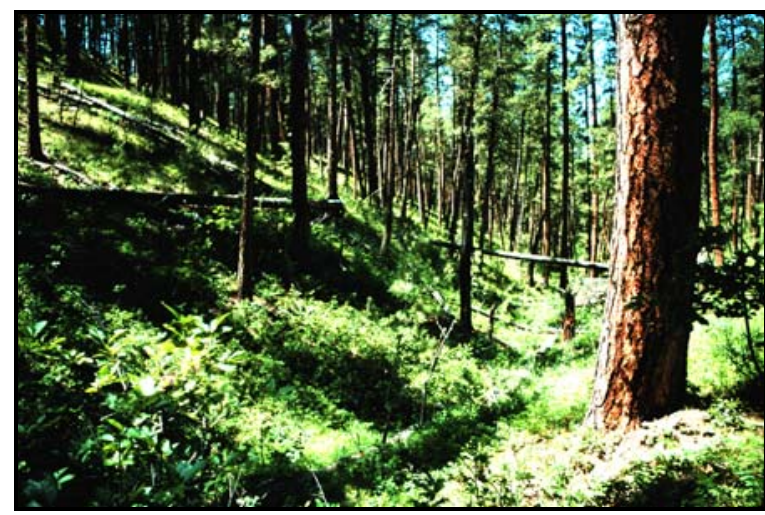

Figure 22. Habitat of Dichanthelium oligosanthes var. scribnerianum

within the Pinus ponderosa / Mahonia repens habitat type, comprised of silty ecological sites with fine sandy loams and loams. The associated species include bluebunch wheatgrass (Pseudoroegneria spicata), Sprengel's sedge (Carex sprengellii), Dewey's sedge (Carex deweyana), and field milkvetch (Astragalus agrestis). Dichanthedlium oligosanthes has two growth forms in different times of the growing season, requiring partial or direct sunlight throughout the season.

In Powder River County, it has only been found in four places on the Ashland District of Custer National Forest. There are few pine stands represented on BLM lands in the study area. Of the few that were visited in the course of this survey, none appeared to have suitable microhabitat. No additional data were collected on this species and its distribution.

Other: This species occupies open pine woodland that may be affected by vegetation encroachment and by grazing, particularly early in the growing 
season. It does not compete with sod-forming grasses like Kentucky bluegrass (Poa pratensis).

One of the Ashland District sites where the species was recorded had burned (occurrence no. 003). Only one plant was found, indicating a capacity for survival without providing basis for interpreting species' response to fire. We note that Dichanthelium wilcoxianum, which has a similar growth form, was locally common following the 1988 wildfires in the Sioux District (Heidel and Dueholm 1995).

\section{Mentzelia nuda (Pursh) Torrey \& Gray}

Bractless mentzelia

Loasa Family (Loaseae)

BLM status: Watch

USFS status: -

Global rank: G5, State rank: S1

State status summary: Bractless mentzelia is known from over five occurrences in Montana, but three of them are historic and the numbers of plants in most occurrences are low.

Description: Bractless mentzelia is an herbaceous biennial or short-lived perennial with one to a few erect, branched stems that arise from a taproot and are up to $1 \mathrm{~m}$ high. The lance-shaped, alternate leaves are 4 to $10 \mathrm{~cm}$ long, have deeply-toothed margins, and are petiolate below but sessile above. Foliage is covered with short, barbed hairs that cause it to stick to clothing like Velcro. Flowers that open in late afternoon are borne on short stalks arising from the axils of reduced upper leaves, or bracts. Each flower is 4 to $9 \mathrm{~cm}$ across and has 10, non-overlapping, white petals and numerous exserted stamens (Figure 23). The calyx forms a deep bowl with 5 narrow, pointed lobes that are 10 to $25 \mathrm{~mm}$ long; it also contains the ovary and bears the stamens. The cylindrical seed capsules are 2 to $3 \mathrm{~cm}$ long. Flowering in July.

By comparison, Mentzelia decapetala has larger flowers that are 8 to $15 \mathrm{~cm}$ across, and its petals overlap.

Distribution: This species occurs from eastern Montana to South Dakota, and south to Colorado

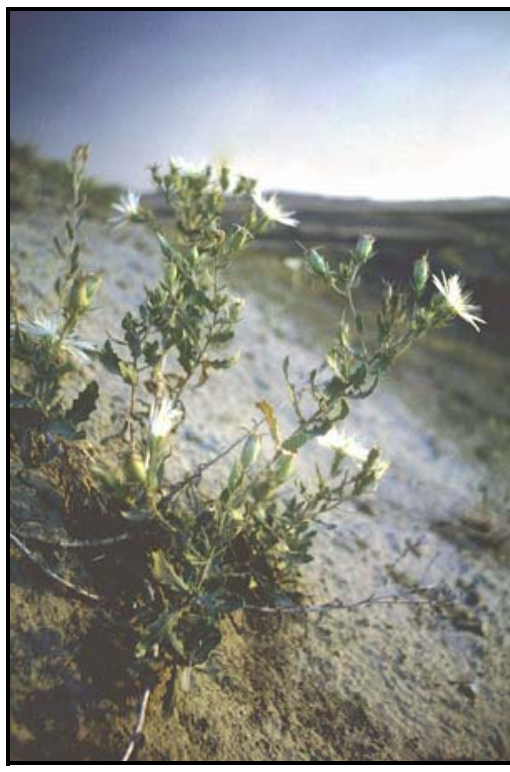

and Texas. In Montana, it has been collected from four counties. It was documented from three occurrences in the northeastern corner of Powder River County, representing the first county records for it. Prior to these, it had not been reported in the state since 1957.

Figure 23. Photograph of Menztelia nuda

Habitat: The species occupies sandy or gravelly soil of open hills and roadsides on the plains. These habitats represent sandy, thin sandy, and shallow to gravel ecological sites.

In Powder River County, it was found in blowouts associated with outcrops, and on the sandstone outcrops themselves.

Comments: This species is potentially affected by road construction, subdivision, and exotic species invasion. The principal habitat and perturbation ecology of this species still needs clarification. All of the population numbers in the study area were very low, but there were no immediate management concerns identified.

\section{Phlox andicola E. Nels.}

Plains phlox

Phlox Family (Polemoniaceae)

BLM status: Watch

USFS status: -

Global rank: G4, State rank: S2

State status summary: Plains phlox is known from over five occurrences. The numbers of plants at most occurrences are low, but it may be more widespread in Montana than records indicate.

Description: Plains phlox is a perennial herb with loosely tufted stems that are 4 to $10 \mathrm{~cm}$ high arising 
from creeping rhizomes. The 5 to 8 pairs of opposite, linear leaves have prominent midveins and whitish bases and are 10 to $25 \mathrm{~mm}$ long, about $1 \mathrm{~mm}$ wide and come to a sharp point. Foliage is glabrous to sparsely hairy. Stems are white. One to five white flowers are borne at the stem tips (Figures 24, 25) Each flower has 5 petals and a tubular corolla. The calyx is also tubular, with 5 lobes, tangled long hairs, and 6 to $11 \mathrm{~mm}$ length. Flowering in May-early June.

The leaves of Phlox hoodii are usually less than 10 $\mathrm{mm}$ long, and the leaves of Phlox alyssifolia are 2 to $5 \mathrm{~mm}$ wide. Flowers are needed for determination, and hybridization between these species is reported elsewhere in the range.

Distribution: This species is distributed from eastern Montana and North Dakota, south to Colorado and Kansas. In Montana it is known from Carter, Powder River and Sheridan counties.

Plains phlox was only located once in the southeastern corner of Powder River County, representing the first county record for it.

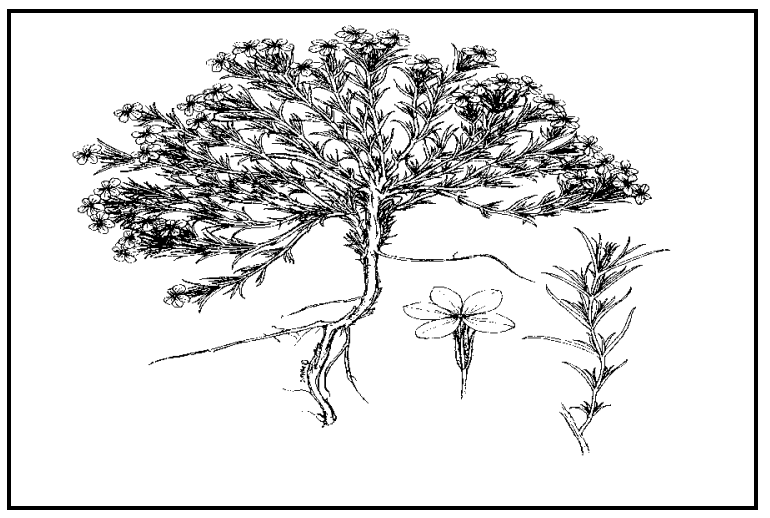

Figure 24. Illustration of Phlox andicola

Habitat: This species occupies sandy soil of grasslands and open pine woodlands on the plains. Most of the settings are well-vegetated, yet there is still bare ground. Associated species are midsuccessional and usually occupy sandy ecological sites.

The single Powder River County population was found in a sandy ecological site, in partially-healed blowout habitats, associated with prairie sandreed
(Calamovilfa longifolia), sandhills bluestem (Andropogon hallii), lemon scurfpea (Psoralea lanceolata) and yucca (Yucca glauca).

Comments: It is an early- to mid-succession species of plains and woodlands subject to

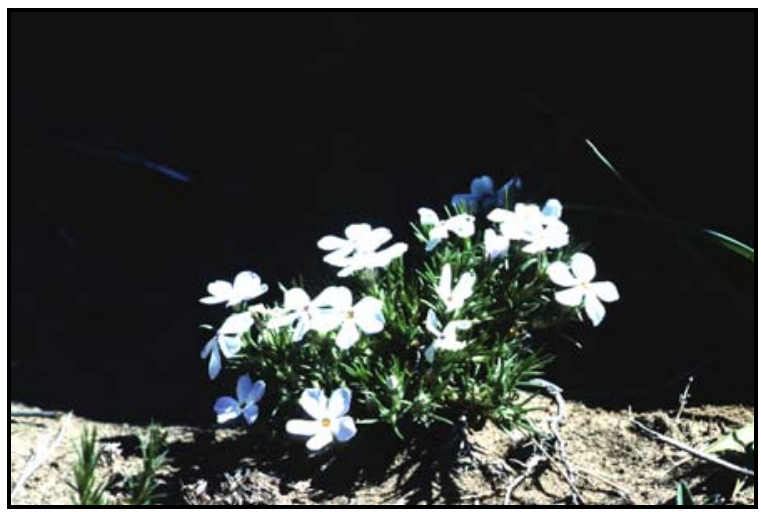

Figure 25. Photograph of Phlox andicola

vegetation encroachment in the more productive settings. Anecdotal observations indicate that it is favored by fall fire and winter grazing. Grazing and disturbances that reduce competition may benefit the species at low levels.

\section{Physaria brassicoides Rydb.}

Double bladderpod

Mustard Family (Brassicaceae)

\section{BLM status: -}

USFS status: -

Global rank: G5, State rank: S2

State status summary: Double bladderpod is known from over five occurrences in Montana, these with mostly low numbers of plants.

Description: Double bladderpod is a perennial herb with numerous ascending stems that are 2 to $17 \mathrm{~cm}$ long and arising from a basal rosette that surmounts a branched crown and large taproot. The basal leaves are 2 to $8 \mathrm{~cm}$ long and are spoonshaped with long petioles (Figure 26). The few, alternate stem leaves are broadly lance-shaped. Foliage is covered with silvery, star-shaped hairs appressed to the surface. The yellow, stalked flowers are borne at the tops of the stems in a narrow inflorescence that elongates as the fruit matures (Figure 27). Each flower has 4 separate 


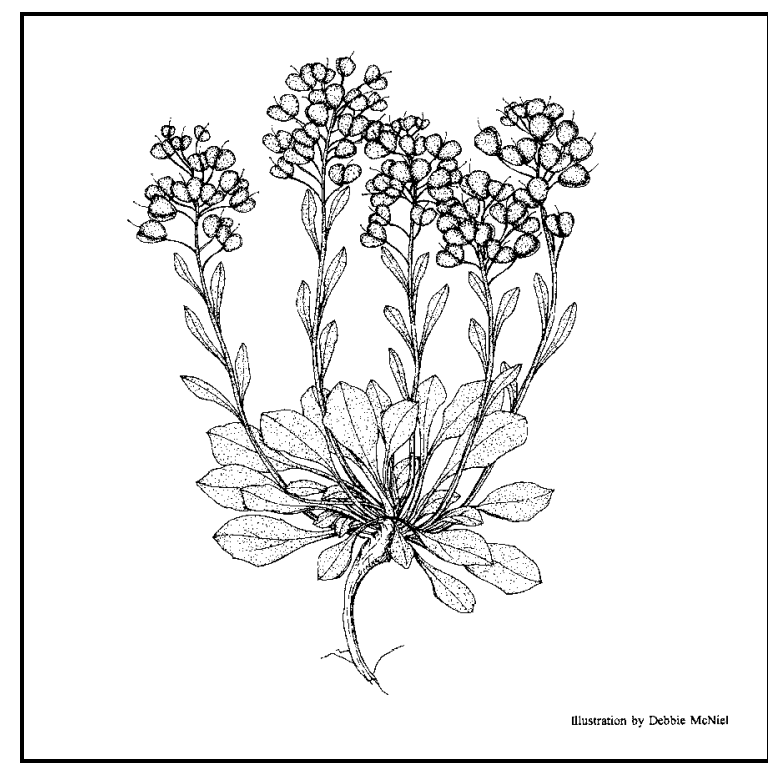

Figure 26. Illustration of Physaria brassicoides

petals that are 9 to $12 \mathrm{~mm}$ long and 4 separate sepals. The ascending, inflated fruits are 1 to $2 \mathrm{~cm}$ long, at least as wide, and flattened on top. They are 2-lobed with the locules (lobes) more deeply defined above than below. There are 2 ovules in each of the locules, attached at the top of the replum (suture between the two locules), and the replum has a linear outline. The style is 6 to $9 \mathrm{~mm}$ long. Flowering in May-early June, fruiting in June-July.

There are many similar-appearing Physaria. Physaria didymocarpa is reported from southeastern Montana. It differs from Physaria brassicoides having a replum that is obovate to elliptic; ovules usually 4 per locule, and funicles not restricted to apex. A technical manual and hand lens or microscope will be required for positive identification.

Distribution: This species is a regional endemic of southwestern North Dakota, southeastern Montana, eastern Wyoming and western Nebraska. In Montana, it is known from three counties to date, including Carter, Powder River and Petroleum counties. It was first documented in the state in 1994 (Heidel and Dueholm 1995, Heidel 1996).

Habitat: Double bladderpod is restricted to sandy or stony soil of open grassland slopes on the plains.
It grows where the vegetation is sparse, often on steep slopes where the slope is unstable and there is little or no profile development. Most settings represent sandy or thin sandy ecological sites. Associated species may include bluebunch wheatgrass (Pseudoroegneria spicatum), goldenweed (Heterotheca villosa), indian ricegrass (Oryzopsis hymenoides), skunkbush (Rhus aromatica), wild begonia (Rumex venosus) and yucca (Yucca glauca).

\section{Comments:}

The species is vulnerable to exotic species competition. Avoid seeding sweetclover (Melilotus spp.) in the area. It is also potentially impacted by road widening, maintenance, and herbicide treatment. It occupies secondary range.

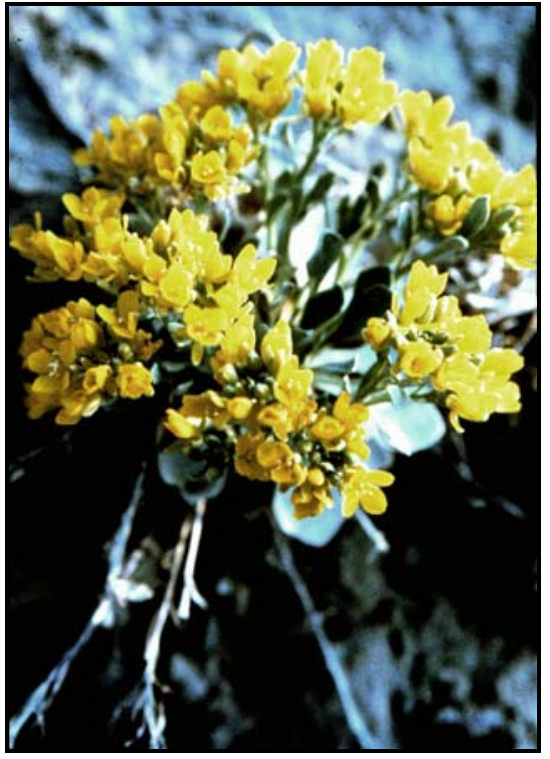

Figure 27. Photograph of Physaria brassicoides

\section{Psoralea hypogaea Nutt.}

Little Indian breadroot

Bean Family (Fabaceae)

BLM status: Watch

USFS status: -

Global rank: G5T4, State rank: S2S3

State status summary: Little Indian breadroot is now treated as a watch species, in light of survey results documenting its breadth of distribution and indicating low vulnerability. There are fewer than twenty occurrences in widespread, localized habitats of eight eastern unglaciated counties. While it is often found in low numbers, it persists under disturbance and annual brome grass encroachment.

Description: Little Indian breadroot is a perennial herb that consists of a rosette of long-petioled leaves that are palmately divided into 3 to 7 linear- 
elliptic leaflets that are 25 to $50 \mathrm{~mm}$ long with a deep, club-shaped root that is up to $6 \mathrm{~cm}$ long and surmounted by a subterranean connecting stem (Figure 28). Above ground, the plant foliage is covered with dot-like glands and dense, white appressed hairs, but the upper leaf surfaces become glabrous with age (Figure 29 and 30). Blue, pealike flowers are borne in condensed spikes arising among the bases of the leaf petioles at or barely above ground-level. The tubular calyx is 6 to 9 $\mathrm{mm}$ long and has 4 long, narrow lobes and a fifth that is longer and broader. The upper petal is 10 to $13 \mathrm{~mm}$ long and held forward. The hairy pods are egg-shaped, ca. $5 \mathrm{~mm}$ long, and each has a beak that is 5 to $13 \mathrm{~mm}$ long. Flowering late May-June.

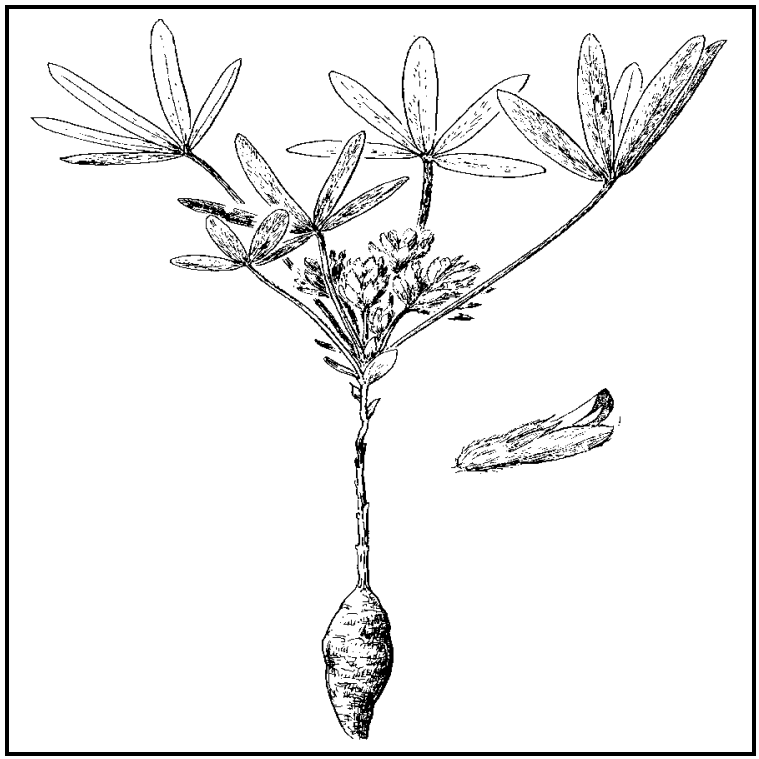

Figure 28. Illustration of Psoralea hypogaea

The common breadroot, Psoralea esculenta, has a distinct flowering stem with spreading pubesence on the stem and leaf petiole, while Psoralea hypogaea is stemless with appressed pubesence. Its flowers are at ground-level.

Distribution: This species of the western Great Plains is found from eastern Montana south to Texas and New Mexico. In Montana, it is widely distributed across unglaciated plains, documented from eight counties to date.

It was found in three of the four corners of Powder River County, and there are more records of it here

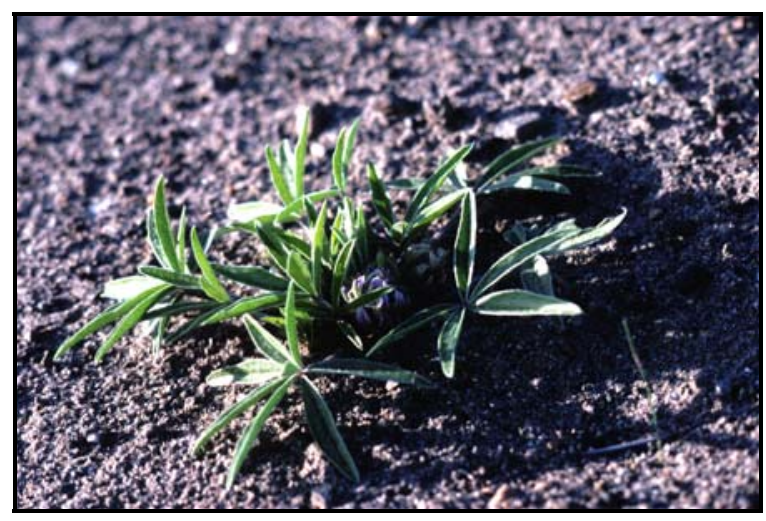

Figure 29. Photograph of Psoralea hypogaea

than in any other county. It was otherwise reported from single isolated populations in studies that were mainly smaller in scale (Heidel 1994, Heidel 1997, Vanderhorst et al. 1998). The sandstone outcrops of Powder River County are widespread but mostly small and isolated, so we make inference from the new distribution information that the species is likely to be more widespread than previously known.

Habitat: Little Indian breadroot occupies sandy ecological sites; mainly in the 10 " to 14 " precipitation. zone across grasslands and open pine woodlands on the eastern sedimentary plains. It is often found in the loose sand below sandstone outcrops, but is known from reworked alluvial sand deposits. It tends to occur in sparsely-vegetated microhabitats where more than half of the bare sand soil surface is exposed. Associated species include sand-loving species such as prairie sandreed (Calamovilfa longifolia), Indian ricegrass (Oryzopsis hymenoides), annual buckwheat (Eriogonum annuum), priaire lupine (Lupinus lepidus), and western spiderwort (Tradescantia occidentalis). The dominant species of the surrounding uplands may be intermingled, including blue grama (Bouteloua gracilis), needleand-thread (Stipa comata) and little bluestem (Schizachyrium scoparium). Both common Indian breadroot (Psoralea esculenta) and silver scurf-pea (Psoralea argophylla) may occasionally be present in low numbers or in the surrounding grasslands.

Powder River settings included ridgetop blowouts, and loose sand slopes around isolated upland 


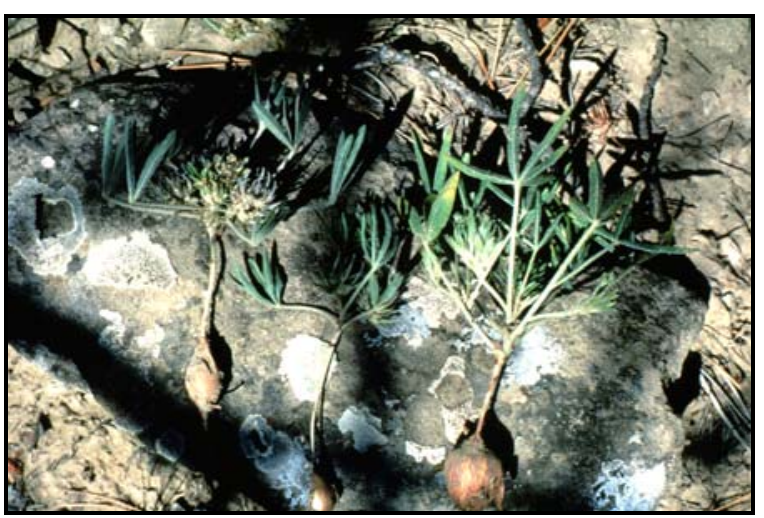

Figure 30. Photograph of Psoralea hypogaea including root

sandstone outcrops and those of the Powder River valley.

Comments: Initial observations indicate that it is not sensitive to grazing and related indirect influences. The size of populations appears to be directly related to the extent of available habitat, with a capacity to persist in low, isolated pockets.

\section{LITERATURE CITED}

Dorn, R. D. 1984. Vascular Plants of Montana. Mountain West Publishing, Cheyenne, WY. $276 \mathrm{pp}$.

Heidel, B. L. 1994. Survey for PSORALEA HYPOGAEA in the Great Falls Resource Area, Lewistown District. Unpublished report to the Bureau of Land Management, Montana. Montana Natural Heritage Program. 22 pp. plus appendices.

Heidel, B. L. and K. H. Dueholm. 1995. Sensitive plant species survey in the Sioux District of Custer National Forest, Carter County, Montana and Harding County, South Dakota. Unpublished report to the Custer National Forest. Montana Natural Heritage Program, Helena. 95 pp. plus appendices.
Heidel, B. and H. Marriott. 1996. Sensitive plant species survey in the Ashland District, Custer National Forest. Report to the U.S. Forest Service. Montana Natural Heritage Program, Helena.

Heidel, B. L. 1997. Preliminary Botanical Survey in the Tongue River Area, Montana. Unpublished report. Montana Natural Heritage Program, Helena. 11 pp. plus appendices and map.

Parker, J. L., L. R. Guptill, K. M. Bajema, W. A. Berg, L. Logan, and R. E. Adams. 1971. Soil Survey of Powder River Area, Montana. Soil Conservation Service (Natural Resources Conservation Service), Bozeman, MT.

Schassberger, L. A. 1988. Status review of Astragalus barrii, Custer National Forest. Unpublished report. Montana Natural Heritage Program, Helena. 61 pp.

Schassberger, L. A. 1990. Report on the conservation status of Astragalus barrii, a candidate threatened species. Unpublished report to the U.S. Fish and Wildlife Service, Denver. Montana Natural Heritage Program, Helena. 85 pp.

Vanderhorst, J., S. V. Cooper, and B. Heidel. 1998. Botanical and vegetation survey of Carter County, Montana. Unpublished report to Bureau of Land Management. Montana Natural Heritage Program, Helena. 116 pp. + app. 
Appendix D: Rangeland Ecological Sites and Plant Associations 
Range Ecological Sites and Plant Associations

Sedimentary Plains, East (MLRA 58AE)

\begin{tabular}{|l|l|l|}
\hline \multirow{2}{*}{ Ecological Site Types } & Plant Associations Found Within Different Precipitation Zones \\
\cline { 2 - 3 } & $\mathbf{1 0}$ to $\mathbf{1 4}$ inch & $\mathbf{1 5}$ to 19 inch \\
\hline
\end{tabular}

\begin{tabular}{|l|l|l|l|}
\hline Riparian Subirrigated & $\bullet \quad$ Salix exigua Temporarily Flooded & $\bullet \quad$ Populus deltoides / Symphoricarpos \\
\hline
\end{tabular}

\begin{tabular}{|l|l|l|}
\hline Riparian Meadow & $\bullet \begin{array}{l}\text { Spartina pectinata Western Herba- } \\
\text { ceous Vegetation }\end{array}$ & \\
\hline
\end{tabular}

\begin{tabular}{|l|l|l|}
\hline & $\bullet$ & $\begin{array}{l}\text { Schoenoplectus pungens Herbaceous } \\
\text { Vegetation }\end{array}$ \\
Riparian Emergent & $\begin{array}{l}\text { Phalaris arundinacea } \text { Herbaceous } \\
\text { Vegetation }\end{array}$ & $\bullet \begin{array}{l}\text { Phalaris arundinacea } \text { Herbaceous } \\
\text { Vegetation }\end{array}$ \\
\hline
\end{tabular}

\begin{tabular}{|c|c|c|}
\hline Subirrigated & $\begin{array}{l}\text { - } \quad \text { Eleocharis palustris Herbaceous } \\
\text { Vegetation } \\
\text { - } \quad \text { Symphoricarpos occidentalis Shrub- } \\
\text { land }{ }^{1} \\
\text { - Pacopyrum smithii - Hordeum juba- } \\
\text { tum Herbaceous Vegetation }{ }^{1}\end{array}$ & $\begin{array}{l}\text { - } \quad \text { Eleocharis palustris Herbaceous } \\
\text { Vegetation } \\
\text { - } \quad \text { Symphoricarpos occidentalis Shrub- } \\
\text { - } \text { land }^{1} \\
\text { Pacopyrum smithii - Hordeum juba- } \\
\text { tum Herbaceous Vegetation }\end{array}$ \\
\hline
\end{tabular}

\begin{tabular}{|l|l|l|}
\hline Saline Lowland & $\bullet \begin{array}{l}\text { Sarcobatus vermiculatus / Pascopyrum } \\
\text { smithii (Elymus lanceolatus) Shrub } \\
\text { Herbaceous Vegetation }\end{array}$ & \\
\hline
\end{tabular}

\begin{tabular}{|c|c|c|}
\hline Saline Upland & $\begin{array}{l}\text { - } \quad \text { Sarcobatus vermiculatus / Pseu- } \\
\text { doroegneria spicata } \text { Shrubland } \\
\text { - } \quad \text { Sarcobatus vermiculatus - Artemisia } \\
\text { tridentata } \text { Shrubland }^{1}\end{array}$ & 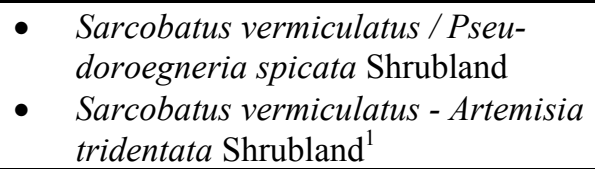 \\
\hline
\end{tabular}

\begin{tabular}{|c|c|c|}
\hline Wet Meadow & $\begin{array}{l}\text { - Carex nebrascensis Herbaceous Vege- } \\
\text { tation }{ }^{1} \\
\text { - Carex lanuginosa - Calamagrostis } \\
\text { stricta Herbaceous Vegetation } \\
\text { - } \text { Juncus balticus } \text { Herbaceous Vegeta- }^{1} \\
\text { tion }^{1}\end{array}$ & $\begin{array}{l}\text { - } \quad \text { Carex nebrascensis Herbaceous } \\
\text { Vegetation }{ }^{1} \\
\text { - } \quad \text { Carex lanuginosa - Calamagrostis } \\
\text { stricta Herbaceous Vegetation }{ }^{1} \\
\text { - Juncus balticus } \text { Herbaceous Vegeta- } \\
\text { tion }^{1}\end{array}$ \\
\hline
\end{tabular}

\begin{tabular}{|c|c|c|}
\hline Closed Depression & $\begin{array}{l}\text { - } \\
\text { Eleocharis palustris Herbaceous } \\
\text { - } \quad \text { Pacopyrum smithii - Hordeum juba- } \\
\text { tum Herbaceous Vegetation }{ }^{1} \\
\text { - } \begin{array}{l}\text { Pacopyrum smithii Herbaceous Vege- } \\
\text { tation }\end{array}\end{array}$ & 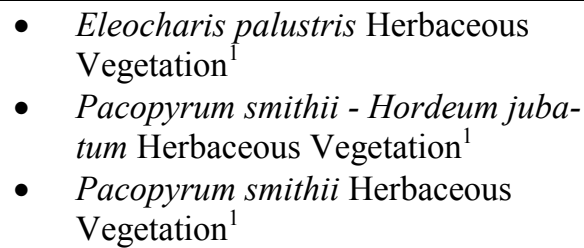 \\
\hline
\end{tabular}




\begin{tabular}{|l|l|l|}
\hline \multirow{2}{*}{ Ecological Site Types } & Plant Associations Found Within Different Precipitation Zones \\
\cline { 2 - 3 } & $\mathbf{1 0}$ to 14 inch & 15 to 19 inch \\
\hline
\end{tabular}

\begin{tabular}{|l|l|l|}
\hline & & $\begin{array}{l}\text { Fraxinus pennsylvanica / Prunus vir- } \\
\text { giniana } \text { Forest }\end{array}$ \\
& & $\begin{array}{l}\text { Pinus ponderosa / Prunus virginiana } \\
\text { Forest }\end{array}$ \\
Overflow & $\begin{array}{l}\text { Artemisia cana / Pascopyrum smithii } \\
\text { Shrubland }\end{array}$ & $\begin{array}{l}\text { Artemisia cana / Pascopyrum smithii } \\
\text { Shrubland }\end{array}$ \\
& $\begin{array}{l}\text { Artemisia cana ssp. cana / Pascopy- } \\
\text { rum smithii Shrub Herbaceous }{ }^{1} \\
\text { Symphoricarpos occidentalis Shrub- } \\
\text { land }^{1}\end{array}$ & $\begin{array}{l}\text { Artemisia cana ssp. cana / Pascopy- } \\
\text { rum smithii Shrub Herbaceous }\end{array}$ \\
\hline
\end{tabular}

\begin{tabular}{|c|c|c|}
\hline Sandy & $\begin{array}{l}\text { - Pinus ponderosa / Pseudoroegneria } \\
\text { - } \quad \text { Anicata Woodland } \\
\text { longifolia Herbaceous Vegetation } \\
\text { - } \quad \text { Calamovilfa longifolia - Hesperostipa } \\
\text { comata Herbaceous Vegetation } \\
\text { - Schizachyrium scoparium - Bouteloua } \\
\text { (curtipendula, gracilis) / Carex filifo- } \\
\text { lia Herbaceous Vegetation } \\
\text { - Schizachyrium scoparium - Carex } \\
\text { inops ssp. heliophila Herbaceous } \\
\text { Vegetation } \\
\text { - Hesperostipa comata - Bouteloua } \\
\text { gracilis - Carex filifolia Herbaceous } \\
\text { Vegetation } \\
\text { - Calamovilfa longifolia - Cares inops } \\
\text { ssp. heliophila Herbaceous Vegeta- } \\
\text { tion }{ }^{1} \\
\text { Krascheninnikovia lanata / Hes- } \\
\text { perostipa comata Dwarf-shrubland }\end{array}$ & 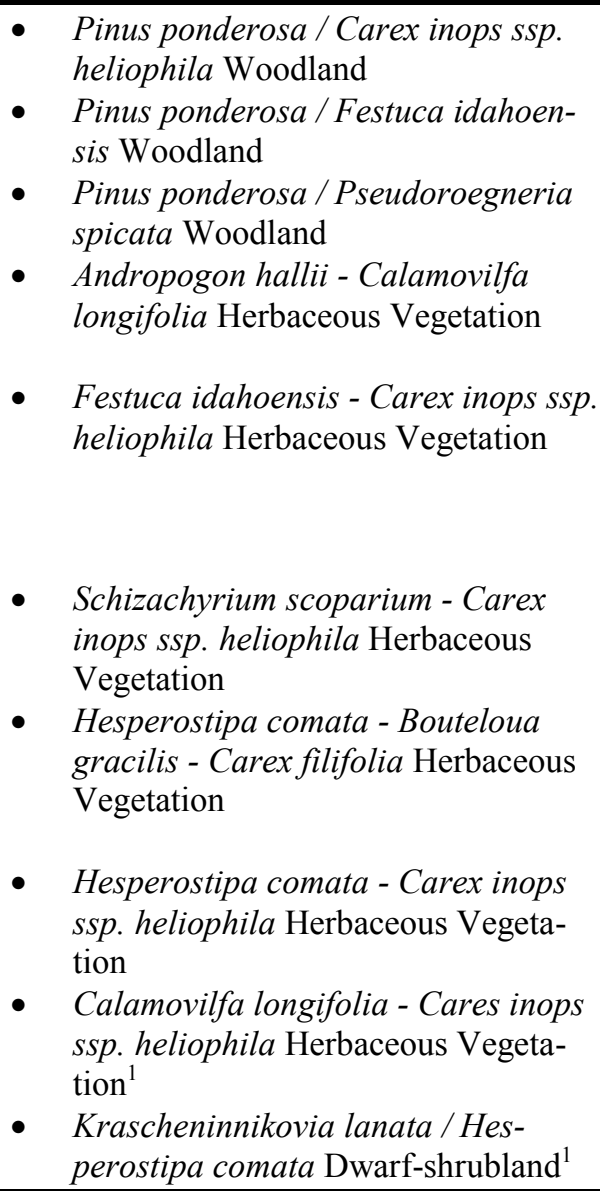 \\
\hline Sands & $\begin{array}{ll}\text { - } & \text { Andropogon hallii - Calamovilfa } \\
& \text { longifolia Herbaceous Vegetation }\end{array}$ & \\
\hline
\end{tabular}




\begin{tabular}{|l|l|l|}
\hline \multirow{2}{*}{ Ecological Site Types } & \multicolumn{2}{|l|}{ Plant Associations Found Within Different Precipitation Zones } \\
\cline { 2 - 3 } & $\mathbf{1 0}$ to $\mathbf{1 4}$ inch & $\mathbf{1 5}$ to $\mathbf{1 9}$ inch \\
\hline
\end{tabular}

\begin{tabular}{|c|c|c|}
\hline Silty & $\begin{array}{l}\text { - Juniperus scopulorum / Piptatherum } \\
\text { micranthum Woodland } \\
\text { - } \quad \text { Pinus ponderosa / Pseudoroegneria } \\
\text { spicata Woodland } \\
\text { - Pinus ponderosa / Juniperus horizon- } \\
\text { talis Woodland }{ }^{1} \\
\text { - Pascopyrum smithii - Bouteloua } \\
\text { gracilis - Carex filifolia Herbaceous } \\
\text { Vegetation } \\
\text { - } \\
\text { Pseudoroegneria spicata - Carex fili- } \\
\text { folia } \text { Herbaceous Vegetation } \\
\text { Pseudoroegneria spicata - Pascopy- } \\
\text { rum smithii Herbaceous Vegetation }{ }^{1} \\
\text { Artemisia tridentata ssp. wyomingen- } \\
\text { sis / Pascopyrum smithii Shrubland }{ }^{1}\end{array}$ & $\begin{array}{l}\text { - } \quad \text { Pinus ponderosa / Carex inops ssp. } \\
\text { heliophila Woodland } \\
\text { - Pinus ponderosa / Pseudoroegneria } \\
\text { spicata Woodland } \\
\text { - Pinus ponderosa / Juniperus horizon- } \\
\text { talis Woodland } \\
\text { - } \\
\text { Pascopyrum smithii - Bouteloua } \\
\text { gracilis - Carex filifolia Herbaceous } \\
\text { Vegetation } \\
\text { Festuca idahoensis - Carex inops ssp. } \\
\text { heliophila Herbaceous Vegetation } \\
\text { Pseudoroegneria spicata - Carex fili- } \\
\text { folia } \text { Herbaceous Vegetation } \\
\text { Pseudoroegneria spicata - Pascopy- } \\
\text { rum smithii Herbaceous Vegetation }{ }^{1} \\
\text { Artemisia tridentata ssp. wyomingen- } \\
\text { sis / Pascopyrum smithii } \text { Shrubland }{ }^{1}\end{array}$ \\
\hline
\end{tabular}

\begin{tabular}{|c|c|c|}
\hline Clayey & $\begin{array}{l}\text { - } \\
\text { Artemisia tridentata ssp. wyomingen- } \\
\text { - } \quad \text { Pascopyrum smithii - Bouteloua } \\
\text { gracilis - Carex filifolia } \text { Herbaceous } \\
\text { Vegetation } \\
\text { - } \text { Atriplex gardnerii / Pascopyrum }^{1} \\
\text { - } \text { smithii Dwarf-shrubland }^{1} \\
\text { Pascopyrum smithii Herbaceous } \\
\text { Vegetation }^{1}\end{array}$ & 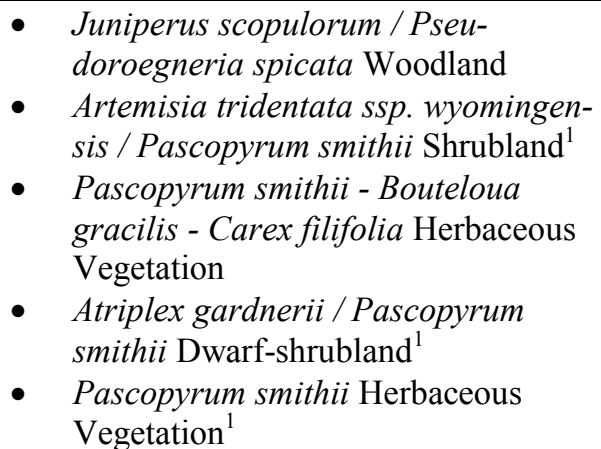 \\
\hline
\end{tabular}

\begin{tabular}{|l|l|l|}
\hline Thin Hilly & & \\
\hline
\end{tabular}

\begin{tabular}{|l|l|l|}
\hline & $\bullet$ & $\begin{array}{l}\text { Carex lanuginosa - Calamagrostis } \\
\text { stricta Herbaceous Vegetation }\end{array}$ \\
Pan Spots & $\begin{array}{l}\text { Eriogonum pauciflorum - Gutierrezia } \\
\text { sarothrae Badlands Sparse Vegeta- } \\
\text { tion }\end{array}$ & \\
\hline
\end{tabular}

Badlands 


\begin{tabular}{|l|l|l|}
\hline \multirow{2}{*}{ Ecological Site Types } & Plant Associations Found Within Different Precipitation Zones \\
\cline { 2 - 3 } & $\mathbf{1 0}$ to 14 inch & 15 to 19 inch \\
\hline
\end{tabular}

\begin{tabular}{|c|c|c|}
\hline Shallow to Gravel & $\begin{array}{l}\text { - Pinus ponderosa / Pseudoroegneria } \\
\text { spicata Woodland } \\
\text { - Schizachyrium scoparium - Bouteloua } \\
\text { (curtipendula gracilis) / Carex filifo- } \\
\text { lia Herbaceous Vegetation }\end{array}$ & $\begin{array}{l}\text { - Pinus ponderosa / Pseudoroegneria } \\
\text { spicata Woodland }\end{array}$ \\
\hline
\end{tabular}

\begin{tabular}{|l|l|l|l|}
\hline \multirow{1}{*}{ Thin Silty } & $\bullet \begin{array}{l}\text { Artemisia tridentata ssp wyomingen- } \\
\text { sis / Pascopyrum smithii Shrub Her- } \\
\text { baceous Vegetation }\end{array}$ & $\bullet \begin{array}{l}\text { Artemisia tridentata ssp wyomingen- } \\
\text { sis / Pascopyrum smithii Shrub Her- } \\
\text { baceous Vegetation }\end{array}$ \\
& $\begin{array}{l}\text { Pseudoroegneria spicata } \text { - Bouteloua } \\
\text { curtipendula Herbaceous Vegetation }\end{array}$ & $\bullet \begin{array}{l}\text { Pseudoroegneria spicata } \text { - Bouteloua } \\
\text { curtipendula } \text { Herbaceous Vegetation }\end{array}$ \\
\hline
\end{tabular}

\begin{tabular}{|l|l|l|}
\hline & $\bullet \begin{array}{l}\text { Hesperostipacomata - Carex filifolia } \\
\text { Herbaceous Vegetation }\end{array}$ & $\bullet \begin{array}{l}\text { Hesperostipacomata - Carex filifolia } \\
\text { Herbaceous Vegetation }\end{array}$ \\
& $\begin{array}{l}\text { Rhus trilobata / Pseudoroegneria spi- } \\
\text { cata Shrub Herbaceous Vegetation }\end{array}$ & $\bullet \begin{array}{l}\text { Rhus trilobata / Pseudoroegneria } \\
\text { spicata Shrub Herbaceous Vegeta- } \\
\text { tion }\end{array}$ \\
\hline
\end{tabular}

\begin{tabular}{|l|l|l|}
\hline & $\bullet \begin{array}{l}\text { Artemisia tridentata ssp. wyomingen- } \\
\text { sis / Pseudoroegneria spicata Shrub- } \\
\text { land }\end{array}$ & $\bullet \begin{array}{l}\text { Artemisia tridentata ssp. wyomin- } \\
\text { gensis / Pseudoroegneria spicata } \\
\text { Shrubland }\end{array}$ \\
& $\begin{array}{l}\text { Rhus trilobata / Pseudoroegneria spi- } \\
\text { cata Shrub Herbaceous Vegetation }\end{array}$ & $\begin{array}{l}\text { Rhus trilobata / Pseudoroegneria } \\
\text { spicata Shrub Herbaceous Vegeta- } \\
\text { tion }\end{array}$ \\
\hline
\end{tabular}

\begin{tabular}{|l|l|l|}
\hline Shale & $\bullet \begin{array}{l}\text { Atriplex confertifolia }- \text { Artemisia tri- } \\
\text { dentata Shrubland }\end{array}$ & $\bullet \begin{array}{l}\text { Atriplex confertifolia }- \text { Artemisia tri- } \\
\text { dentata Shrubland }\end{array}$ \\
\hline
\end{tabular}

${ }^{1}$ Plant association provisionally assigned to this Ecological Site (and both precipitation zones); more information needed to confirm placement. 
Appendix E. Plant Community Descriptions 
Plant community descriptions that follow are organized within the hierarchical framework of the National Vegetation Standard (FGDC 1997). These descriptions exhibit varying degrees of completeness. The most complete plant association descriptions are generally taken from the International Classification of Ecological Communities maintained by NatureServe and updated by state Natural Heritage programs (NatureServe 2002). A few plant associations recently described by the Montana Natural Heritage Program have been nominated for inclusion into the International Classification; these associations are identified by the identifier prefix CEGLMTHP.

\section{Table of Contents}

I. FOREST

I.A.8.N.b.10. PINUS PONDEROSA FOREST ALLIANCE Pinus ponderosa / Prunus virginiana Forest 4

II. WOODLAND $\quad 6$

II.A.4.N.a.8. JUNIPERUS SCOPULORUM WOODLAND ALLIANCE Juniperus scopulorum / Piptatherum micranthum Woodland 6 $\begin{array}{ll}\text { Juniperus scopulorum / Pseudoroegneria spicata Woodland } & 7\end{array}$

II.A.4.N.a.32. PINUS PONDEROSA WOODLAND ALLIANCE

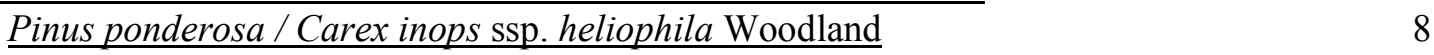
Pinus ponderosa / Juniperus horizontalis Woodland $\quad 9$ $\begin{array}{ll}\text { Pinus ponderosa / Pseudoroegneria spicata Woodland } & 10\end{array}$

II.B.2.N.b.4. POPULUS DELTOIDES TEMPORARILY FLOODED WOODLAND

ALLIANCE $\quad 11$

Populus deltoides / Symphoricarpos occidentalis Woodland 11

III. SHRUBLAND 13

III.A.4.N.a.20. ARTEMISIA TRIDENTATA SSP. WYOMINGENSIS SHRUBLAND

ALLIANCE 13 Artemisia tridentata ssp. wyomingensis / Pascopyrum smithii Shrubland 13 Artemisia tridentata ssp. wyomingensis / Pseudoroegneria spicata Shrubland $\quad 15$

III.A.4.N.c.2. ARTEMISIA CANA TEMPORARILY FLOODED SHRUBLAND

ALLIANCE Artemisia cana / Pascopyrum smithii Shrubland 16

III.B.2.N.d.6. SALIX (EXIGUA, INTERIOR) TEMPORARILY FLOODED

SHRUBLAND ALLIANCE $\quad 17$

$\begin{array}{ll}\text { Salix exigua Temporarily Flooded Shrubland } & 17\end{array}$

III.B.2.N.d.20. SYMPHORICARPOS OCCIDENTALIS TEMPORARILY FLOODED

$\begin{array}{ll}\text { SHRUBLAND ALLIANCE } & 18\end{array}$ Symphoricarpos occidentalis Shrubland 18

III.B.3.N.a.14. SARCOBATUS VERMICULATUS SHRUBLAND ALLIANCE 20 Sarcobatus vermiculatus / Pseudoroegneria spicata Shrubland 20

V. HERBACEOUS VEGETATION 22

V.A.5.N.a.3. ANDROPOGON HALLII HERBACEOUS ALLIANCE Andropogon hallii - Calamovilfa longifolia Herbaceous Vegetation $\quad 22$ Andropogon hallii - Carex inops ssp. heliophila Herbaceous Vegetation 24

V.A.5.N.a.11. CALAMOVILFA LONGIFOLIA HERBACEOUS ALLIANCE Calamovilfa longifolia - Carex inops ssp. heliophila Herbaceous Vegetation 
Calamovilfa longifolia - Hesperostipa comata Herbaceous Vegetation

V.A.5.N.c.29. HESPEROSTIPA COMATA - BOUTELOUA GRACILIS

HERBACEOUS ALLIANCE

Hesperostipa comata - Bouteloua gracilis - Carex filifolia Herbaceous Vegetation $\quad 28$

Hesperostipa comata - Carex filifolia Herbaceous Vegetation 29

V.A.5.N.c.27. PASCOPYRUM SMITHII HERBACEOUS ALLIANCE 30

$\begin{array}{ll}\text { Pascopyrum smithii - Bouteloua gracilis - Carex filifolia Herbaceous Vegetation } & 30\end{array}$

Pascopyrum smithii Herbaceous Vegetation

V.A.5.N.c.20. SCHIZACHYRIUM SCOPARIUM - BOUTELOUA CURTIPENDULA

HERBACEOUS ALLIANCE

Schizachyrium scoparium - Bouteloua (curtipendula, gracilis) - Carex filifolia

Herbaceous Vegetation

V.A.5.N.c.35. SCHIZACHYRIUM SCOPARIUM HERBACEOUS ALLIANCE

Schizachyrium scoparium - Carex inops ssp. heliophila Herbaceous Vegetation

V.A.5.N.d.8. FESTUCA IDAHOENSIS HERBACEOUS ALLIANCE

Festuca idahoensis - Carex inops ssp. heliophila Herbaceous Vegetation

V.A.5.N.d.22. PSEUDOROEGNERIA SPICATA HERBACEOUS ALLIANCE

Pseudoroegneria spicata - Bouteloua curtipendula Herbaceous Vegetation

Pseudoroegneria spicata - Carex filifolia Herbaceous Vegetation

Pseudoroegneria spicata - Pascopyrum smithii Herbaceous Vegetation

34

35

35

36

36

36

36

38

38

V.A.5.N.j.18. PASCOPYRUM SMITHII TEMPORARILY FLOODED

HERBACEOUS ALLIANCE

Pascopyrum smithii - Hordeum jubatum Herbaceous Vegetation

V.A.5.N.j.11. SPARTINA PECTINATA TEMPORARILY FLOODED

HERBACEOUS ALLIANCE

Spartina pectinata Western Herbaceous Vegetation

40

V.A.5.N.k.56. CAREX NEBRASCENSIS SEASONALLY FLOODED

HERBACEOUS ALLIANCE

Carex nebrascensis Herbaceous Vegetation

V.A.5.N.k.53. CAREX PELLITA SEASONALLY FLOODED HERBACEOUS

ALLIANCE

42

Carex pellita - Calamagrostis stricta Herbaceous Vegetation

V.A.5.N.k.61. ELEOCHARIS PALUSTRIS SEASONALLY FLOODED

HERBACEOUS ALLIANCE

Eleocharis palustris Herbaceous Vegetation

V.A.5.N.k.13. JUNCUS BALTICUS SEASONALLY FLOODED HERBACEOUS

ALLIANCE Juncus balticus Herbaceous Vegetation

V.A.5.N.k.20. PHALARIS ARUNDINACEA SEASONALLY FLOODED

HERBACEOUS ALLIANCE

Phalaris arundinacea Western Herbaceous Vegetation

V.A.5.N.1.6. SCHOENOPLECTUS PUNGENS SEMIPERMANENTLY FLOODED

HERBACEOUS ALLIANCE

$\begin{array}{ll}\text { Schoenoplectus pungens Herbaceous Vegetation } & 47\end{array}$

V.A.7.N.e.11. ARTEMISIA CANA SHRUB HERBACEOUS ALLIANCE 48 Artemisia cana ssp. cana / Pascopyrum smithii Shrub Herbaceous Vegetation 48

V.A.7.N.g.5. RHUS TRILOBATA SHRUB HERBACEOUS ALLIANCE

Rhus trilobata / Pseudoroegneria spicata Shrub Herbaceous Vegetation 
V.A.7.N.n.1. SARCOBATUS VERMICULATUS INTERMITTENTLY FLOODED SHRUB HERBACEOUS ALLIANCE

Sarcobatus vermiculatus / Pascopyrum smithii - (Elymus lanceolatus) Shrub Herbaceous Vegetation

VII. SPARSE VEGETATION

VII.C.4.N.a.400. ERIOGONUM PAUCIFLORUM SPARSE VEGETATION ALLIANCE

Eriogonum pauciflorum - Gutierrezia sarothrae Badlands Sparse Vegetation $\underline{\text { References }}$
50

52

0

52

53

Appendix E-3 


\title{
I. FOREST
}

\section{I.A.8.N.b. Rounded-crowned temperate or subpolar needle-leaved evergreen forest}

\author{
I.A.8.N.B.10. PINUS PONDEROSA FOREST ALLIANCE \\ ELEMENT CONCEPT
}

\section{PINUS PONDERosa / PRUNUS VIRGINIANA FOREST}

Ponderosa Pine / Choke Cherry Forest

\begin{abstract}
Summary: This community type is found in the Black Hills and northeastern Rocky Mountains, and western Great Plains escarpments of the United States. It occurs on gentle to moderate (2-40\%), north-facing slopes and close to streams. A few stands are on rolling uplands. The soils are sandy loam or loam. This forest community has a closed canopy of Pinus ponderosa. Seedlings and saplings of Crataegus succulenta and Fraxinus pennsylvanica are often scattered in the understory. These species may grow to be mature trees near streams. There are two shrub layers in this community. The most prominent layer is approximately $1 \mathrm{~m}$ tall and dominated by Prunus virginiana. Amelanchier alnifolia also contributes significantly to this layer. The lower shrub layer is approximately $50 \mathrm{~cm}$ tall. It is dominated by Mahonia repens with lesser amounts of Juniperus communis, Ribes missouriense, Rosa woodsii, Symphoricarpos albus, and Toxicodendron rydbergii. The diversity of forbs is moderate, but most of the coverage of the herbaceous layer is provided by graminoids. Apocynum androsaemifolium, Elymus caninus, Carex inops ssp. heliophila, Galium boreale, Schizachne purpurascens, and Maianthemum stellatum are typical components of the herbaceous layer.
\end{abstract}

Environment: This is one of the most mesic ponderosa pine communities. It occurs on gentle to moderate (240\%) north-facing slopes and close to streams (Hansen and Hoffman 1988). A few stands are on rolling uplands. The soils are sandy loam or loam.

Vegetation: This forest community has a closed canopy made up of Pinus ponderosa. Hansen and Hoffman (1988) found that the basal area ranged from 36.6-63.5 m2/ha in five stands in southeastern Montana. Seedlings and saplings of Crataegus succulenta and Fraxinus pennsylvanica are often scattered in the understory. These species may grow to be mature trees near streams. here are two shrub layers in this community. Together they had an average cover of $87 \%$ in five stands sampled by Hansen and Hoffman (1988). The most prominent layer is approximately $1 \mathrm{~m}$ tall and dominated by Prunus virginiana. Amelanchier alnifolia also contributes significantly to this layer. The lower shrub layer is approximately $50 \mathrm{~cm}$ tall. It is dominated by Mahonia repens with lesser amounts of Juniperus communis, Ribes missouriense, Rosa woodsii, Symphoricarpos albus, and Toxicodendron rydbergii. The diversity of forbs is moderate, but most of the coverage of the herbaceous layer is provided by graminoids. Apocynum androsaemifolium, Elymus caninus, Galium boreale, Schizachne purpurascens, and Maianthemum stellatum are typical components of the herbaceous layer.

Dynamics: Signs of fire were noted by Hansen and Hoffman (1988). This community may be regularly affected by ground fires.

GRank \& Reasons: G3 (00-03-16).

Comments: In Nebraska, see comments in Steinauer and Rolfsmeier (2000). In the Black Hills, see Marriott and Faber-Langendoen (2000).

\section{ELEMENT DisTRIBUTION}

Range: This community type is found in the Black Hills and northeastern Rocky Mountains, and western Great Plains escarpments of the United States, ranging from eastern Montana south to western Nebraska.

States/Provinces: MT:S4, NE:S2, SD:S4, WY? 


\section{ELEMENT SOURCES}

Authors: J. Drake, MCS Confidence: 1 Identifier: CEGL000192

References: Driscoll et al. 1984, Hansen and Hoffman 1988, Hansen et al. 1984, Hoffman and Alexander 1987, Pfister et al. 1977, Steinauer and Rolfsmeier 2000 


\section{WOODLAND}

\section{II.A.4.N.a. Rounded-crowned temperate or subpolar needle-leaved evergreen woodland II.A.4.N.A.8. JUNIPERUS SCOPULORUM WOODLAND ALLIANCE}

JUNIPERUS SCOPULORUM / PIPTATHERUM MICRANTHUM WOODLAND

Rocky Mountain Juniper / Little-seed Mountain Ricegrass Woodland

\section{ELEMENT CONCEPT}

Summary: This rocky mountain juniper community type is found in the western Great Plains of the United States. Stands occur almost exclusively on steep (30-70\%) north-facing slopes. The soils are shallow and poorly developed; loamy sands and sandy loams predominate. The vegetation structure and composition is an evergreen woodland with moderately open to dense cover of Juniperus scopulorum, Juniperus virginiana, or introgressant hybrids of the two. Woody species other than Juniperus scopulorum or Juniperus virginiana occur sporadically, but none achieves prominence. Most of the trees are small (10-20 $\mathrm{cm} \mathrm{dbh})$ and few exceed $6 \mathrm{~m}$. Where the density of the tree canopy is high, the short-shrub and herbaceous strata are not well-developed. In more open places Piptatherum micranthum (= Oryzopsis micrantha) is often abundant. Other common herbaceous species include Campanula rotundifolia, Galium boreale, and Maianthemum stellatum. Mosses and lichens can cover much of the ground.

In Montana, only Juniperus scopulorum is present and dominant. This plant association is best-developed on sheltered aspects in dissected sedimentary plains. In Powder River County, this plant association is widelyscattered on escarpments, and dissected terrain along the south end of the Powder River.

Environment: This community typically occurs on moderate to steep (16-70\%), north-facing slopes, but can occur on a variety of aspects (Johnston 1987, Von Loh et al. 1999). The soils are poorly developed, shallow, loamy sands, sandy loams, and clay loams, sometimes with high gravel content. These woodlands are frequently associated with outcrops of sandstone (DeVelice et al. 1995) or scoria and clay slopes (Girard et al. 1989). In Montana, this plant association occurs in a variety of Silty Ecological Sites that are well-drained owing to the slope and the gully-erosion in these settings. This community is best-developed on north aspects.

In Powder River County, this type was found on thin silty ecological conditions. This is consistent with other Montana state data, with exception of thin clay conditions noted in Carter County (Vanderhorst et al. 1998).

Vegetation: This woodland community is dominated by small Juniperus scopulorum trees through most of its range, and is replaced by Juniperus virginiana and introgressant hybrids in the eastern portion of its range in Nebraska and South Dakota (Kaul et al. 1983, Von Loh et al. 1999). Acer negundo and Fraxinus pennsylvanica saplings are sometimes found in depressions where soil and moisture accumulate. Most of the juniper trees are 10$20 \mathrm{~cm}$ dbh and 4-6 $\mathrm{m}$ tall, but some trees can be up to $30-40 \mathrm{~cm}$ dbh. The basal area has been reported at 22-29 $\mathrm{m} 2$ /ha in North Dakota and up to 22-41 m2/ha in southeastern Montana and northwestern South Dakota (Nelson 1961, Hansen et al. 1984, Hansen and Hoffman 1988). Tree canopy is moderate to dense, e.g., in North Dakota, Girard et al. (1989) measured densities of 975 trees/ha. Where the canopy is dense the shrub and herbaceous strata are poorly developed. Where the canopy is less full, shrubs and herbaceous species are more abundant, e.g. on 7 stands in southwest North Dakota mosses and lichens covered $72 \%$ of the ground surface, shrubs covered $17.4 \%$; graminoids $69.1 \%$, and forbs $9.4 \%$ (Hansen et al. 1984). Among the shrubs that may be found in this community are Juniperus communis, Juniperus horizontalis, small Juniperus scopulorum or Juniperus virginiana, Mahonia repens, Dasiphora fruticosa ssp. floribunda (= Pentaphylloides floribunda), Prunus virginiana, Rhus trilobata, Ribes aureum, Ribes cereum, Rosa woodsii, Symphoricarpos albus, and Symphoricarpos occidentalis. Typical herbaceous species include Pulsatilla patens ssp. multifida (= Anemone patens), Antennaria microphylla, Campanula rotundifolia, Carex inops ssp. heliophila, Chenopodium fremontii, Elymus lanceolatus, Elymus trachycaulus, Galium boreale, Geum triflorum, Koeleria macrantha, Piptatherum micranthum (= Oryzopsis micrantha), and Maianthemum stellatum, Parietaria pensylvanica, and Taraxacum officinale (Hansen et al. 1984, 
Hansen and Hoffman 1988).

In Montana, this plant association is distinguished by the palatable bunchgrass Piptatherum micranthum having the highest graminoid cover at generally $10-30 \%$, the absence or paucity of bluebunch wheatgrass (Pseudoroegneria spicata), high nonvascular cover, and often rich forb diversity and cover (DeVelice et al. 1995, Culwell et al. 1986, Vanderhorst et al. 1998). Hybrids between Juniperus scopulorum and Juniperus horizontalis have been reported and may account for the unusual growth form of stands along the Missouri Breaks where trees do not have a central axis (Roberts et al. 1979, Heidel 1997).

Dynamics: This plant association is in relatively moist habitat that is not as prone to burning as surrounding vegetation types, but is highly flammable when dry. Juniperus scopulorum is readily killed by fire; once ignited the crowns are almost always completely incinerated.

GRank \& Reasons: G3G4 (00-01-31). A number of sites have been impacted by cutting for fenceposts or railroad ties. Fire suppression may increase the extent of the community within its range.

Comments: This description includes stands with both Juniperus scopulorum and Juniperus virginiana over a herbaceous layer with Piptatherum micranthum (= Oryzopsis micrantha). Pinus ponderosa, if present, is less than $25 \%$ tree canopy cover.

This type closely intergrades with Juniperus scopulorum / Pseudoroegneria spicata and both may be represented on the same slope or on opposite aspects of the same landform as they were in the dissected terrain along the Powder River. It often has grassland or steppe openings that condition the levels of overall livestock use. Signs of

fencepost-cuttings are ubiquitious in the stands and the changes brought on by this history need to be further addressed in characterizing stand structure.

\section{ELEMENT DisTRIBUTION}

Range: This rocky mountain juniper community type is found in the western Great Plains of the United States. It is found in the Black Hills and the Badlands of North and South Dakota and Montana, and from the High Plains of eastern Wyoming eastward to central Nebraska.

In Montana, this plant association is best represented on the open eastern sedimentary plains associated with river breaks and scattered escarpments. It is sometimes present at the margins of pine woodland landscapes but is not consistently part of them. In Powder River County, this plant association is present on northeastern escarpments, and valley segments of the Powder River in the southwestern corner of the County.

\section{States/Provinces: MT:S3, ND:S3, NE:S4S5, SD:SU}

\section{ELEMENT SOURCES}

Authors: P.L. Hansen, G.R. Hoffman, and A.J. Bjugstad; mod. J. Drake and S. Rolfsmeier, MCS; mod. B. L. Heidel, MTNHP Confidence: 1 Identifier: CEGL000747

References: DeVelice et al. 1995, Driscoll et al. 1984, Girard et al. 1989, Godfread 1994, Hansen 1985, Hansen and Hoffman 1988, Hansen et al. 1984, Johnston 1987, Kaul et al. 1983, Nelson 1961, Von Loh et al. 1999

JUNIPERUS SCOPULORUM / PSEUDOROEGNERIA SPICATA WOODLAND

Rocky Mountain Juniper / Bluebunch Wheatgrass Woodland

\section{Summary:}

\section{ELEMENT CONCEPT}

Environment: In eastern Montana this community type is commonly found in low to moderate relief rolling uplands as well as in badland arroyos/draws, often occurring adjacent to Juniperus scopulorum / Achnatherum hymenoides (=Oryzopsis hymenoides) but on warmer exposures (not strictly north-facing) with the same moderate to steep slopes. In eastern Montana three of the four sampled stands were on calcareous substrates, though this habitat type is not confined to these substrates in this region. It has also been recorded for the Beaverhead Mountains Section occurring on rocky, primarily volcanic substrates with thin soils; substrate conditions here 
appear to be the determining factors in its occurrence. It is primarily associated with lower treeline positions and slope and aspect are only weak determining factors. In eastern Montana, Juniperus scopulorum / Pseudoroegneria spicata also has more exposed soil and rock than the associated to Juniperus scopulorum / Achnatherum hymenoides, often exceeding 50\%. The same situation often obtains in western Montana where bare soil and exposed rock usually constitute $60 \%$ plus of the substrate and litter is never more than $20 \%$ and adjacent shrubland types often have more developed, deeper soils.

Vegetation: As a result of the ubiquitous past cutting for fencing, stands of Juniperus scopulorum / Pseudoroegneria spicata in eastern Montana are rather open, with coverage of 8 to 12 feet tall Juniperus scopulorum not exceeding 50\%; in the Beaverhead Mountains Section, the tree canopy are also quite open (at most approaching $30 \%$ canopy cover). We speculate tree coverage does not much exceed these figures due to limitations of site factors. The higher coverage of shrubs (up to $20 \%$ for Artemisia tridentata and $\sim$ Artemesia frigida combined) that are reported in northeastern Montana as opposed to southeastern Montana (Hansen and Hoffman 1988) is also attributable to seral conditions. In the Beaverhead Mountains Section, Artemisia tridentata ssp. vaseyana and ssp. wyomingensis, Artemesia frigida, Ericameria nauseosa (=Chrysothamnus nauseosus), and Chrysothamnus viscidiflorus have the highest constancy but comprise less than $5 \%$ cover in the aggregate. The undergrowth is dominated by graminoids, chief among which and diagnostic of the type is Pseudoroegneria spicata, always well represented (40\% average cover in eastern Montana only 10\% in SW Montana). Carex filifolia and Koeleria macrantha (=Koeleria cristata) have high constancy and Bouteloua curtipendula is consistently present in the easternmost occurrences of this type. Forb diversity is moderately high and higher in western than eastern Montana with not much overlap in high constancy species between regions; regardless of location, forb coverage's are generally low, not exceeding $10 \%$ except in the most open stands.

\section{Dynamics:}

GRank \& Reasons: G4 (96-02-01).

Comments:

\section{ELEMENT Distribution}

Range:

States/Provinces: CO:S2S3, MT:S4, WY:S4

Authors: WCS Confidence: 1 Identifier: CEGL000748

References: Bighorn Coal Mine n.d., Bourgeron and Engelking 1994, Brown 1971, Driscoll et al. 1984, Francis 1983, Hansen 1985, Hansen and Hoffman 1988, Johnston 1987, Strong 1980, Terwilliger et al. 1979a, Tiedemann et al. 1987

\section{II.A.4.N.A.32. PINUS PONDEROSA WOODLAND ALLIANCE}

PINUS PONDEROSA / CAREX INOPS SSP. HELIOPHILA WOODLAND

Ponderosa Pine / Sun Sedge Woodland

\section{ELEMENT CONCEPT}

Summary: This ponderosa pine / sedge woodland community type is found in the Black Hills region, adjacent Great Plains and northern Rocky Mountain front range. Stands occur in the most mesic of the habitat types with a graminoid-dominated ground layer. They are generally found on moderate south- and west-facing slopes in the western Dakotas, and eastern parts of Wyoming and Montana. The community is dominated by Pinus ponderosa with occasional Juniperus scopulorum and Quercus macrocarpa in the subcanopy. Shrubs are relatively uncommon in this type. The herbaceous layer is dominated by Carex inops ssp. heliophila, with inclusions of Danthonia spicata, Schizachyrium scoparium, and Pseudoroegneria spicata, generally in areas with more open canopies.

Environment: This community is often found on gentle and moderate south- to west-facing slopes (Hansen and Hoffman 1988, Hoffman and Alexander 1987). 
Vegetation: The tree canopy and subcanopy are dominated by Pinus ponderosa. Juniperus scopulorum and Quercus macrocarpa are occasionally found in the subcanopy. Shrubs are infrequent in this type. The herbaceous layer is dominated by Carex inops ssp. heliophila (sun sedge), with inclusions of Danthonia spicata,

Schizachyrium scoparium and Pseudoroegneria spicata, generally in areas with more open canopies. At Wind Cave National Park, herbaceous cover is most commonly in the $25-50 \%$ range and occasionally greater, with sun sedge dominant. Other common herbaceous species include Artemisia ludoviciana, Danthonia spicata,

Piptatherum micranthum (= Oryzopsis micrantha), Nassella viridula, and Poa pratensis (H. Marriott pers. comm. 1999).

Dynamics: This type probably develops from little bluestem prairie as pines become established. Disturbances such as fire convert stands back to prairies (Marriott and Faber-Langendoen 2000). The canopy in this type is usually moderately open due to occasional fires, but can become nearly closed in stands where the natural fire disturbance regime has been disrupted.

GRank \& Reasons: G3G4 (00-05-26).

Comments: The stands used by Hoffman and Alexander (1987) and Hansen and Hoffman (1988) to document the Pinus ponderosa / Carex inops ssp. heliophila Woodland habitat type had very high basal area and densities for a woodland, possibly due to their sampling procedure. The dense structure may have affected the floristic makeup of the stands. This type is expected to have an open canopy where natural fire disturbances occur.

\section{ELEMENT DISTRIBUTION}

Range: This ponderosa pine / sedge woodland community type is found in the Black Hills region, adjacent Great Plains and northern Rocky Mountain front range from Montana, Wyoming and South Dakota south to Colorado.

\section{States/Provinces: CO:S2, MT:S3S4, SD:S?, WY:S2S3}

\section{ELEMENT SOURCES}

Authors: A.G. McAdams, WCS Confidence: 1 Identifier: CEGL000849

References: Bourgeron and Engelking 1994, Driscoll et al. 1984, Hall 1967, Hall 1973, Hansen 1985, Hansen and Hoffman 1988, Hoffman and Alexander 1976, Hoffman and Alexander 1987, Johnston 1987, Kooiman and Linhart 1986, Livingston 1947, Livingston 1949, Marriott and Faber-Langendoen 2000, McAdams et al. 1998

\section{PINUS PONDEROSA / JUNIPERUS HORIZONTALIS WOODLAND}

Ponderosa Pine / Creeping Juniper Woodland

\section{ELEMENT CONCEPT}

Summary: This woodland association has been described from north-central (Little Rocky Mountains) and the plains of northeastern Montana. All occurrences are below $1160 \mathrm{~m}$ (3800 feet) on calcareous shales and sandstones of rolling uplands and foothills, generally on slope shoulders. Except for accidentals of Pseudotsuga menziesii and very scattered Juniperus scopulorum, Pinus ponderosa is the only tree present, with somewhat stunted specimens comprising between $40 \%$ and $70 \%$ canopy cover. The undergrowth is rather depauperate in species diversity. Juniperus horizontalis is always the dominant species but varies enormously in cover, from 10$70 \%$ (even greater cover noted in reconnaissance). Juniperus communis can also attain high cover values but is not consistently present. Rhus trilobata and Artemisia tridentata ssp. wyomingensis are highly constant but seldom comprise more than 5\% cover. There is a strong difference between the stands in the Little Rocky Mountains, which have a very depauperate graminoid cover, and those of northeastern Montana wherein Pseudoroegneria spicata and Pascopyrum smithii can attain canopy covers of greater than $30 \%$. The forb component seldom has more than a trace amount of any species; those with the greatest constancy are Solidago missouriensis, Thermopsis rhombifolia, and Linum perenne. Structurally and compositionally this association is similar to both Pinus ponderosa / Juniperus communis Woodland (CEGL000859) and Pinus flexilis / Juniperus communis Woodland (CEGL000807).

Rank \& Reasons: G3? (00-01-09). This type appears to have a rather limited geographic range and few known occurrences; conversely there is an abundance of potential habitat that could support this woodland type. It is proposed that the rank be changed from G3 to G3? Queries of federal agency resource managers in eastern 
Montana resulted in no positive responses from any of them as to having seen this community. With only 6 plots documented and virtually no reconnaissance information it would seem that this type is rarer than indicated by G3 alone, but indeed it could be more common, thus the ? added to rank.

Comments: Only 6 plots have been documented for this association and limited reconnaissance notes recorded in the course of the Northern Great Plains Ecoregion Rapid Ecological Survey. This type is relatively easily distinguished from other Pinus ponderosa-dominated types by its abundance of Juniperus horizontalis, though it could be confused with Pinus flexilis / Juniperus communis Woodland (CEGL000807) growing on poor sites if one rushed to judgment on the tree species dominant.

\section{ELEMENT DisTRIBUTION}

Range: This woodland association has been described from the Little Rocky Mountains in north-central Montana and the plains of northeastern Montana.

States/Provinces: MT:S3

\section{ELEMENT SOURCES}

Authors: S.V. Cooper, WCS Confidence: 2 Identifier: CEGL000860

References: Bourgeron and Engelking 1994, DeVelice et al. 1995, Driscoll et al. 1984, Roberts 1980

\section{PINUS PONDEROSA / PSEUDOROEGNERIA SPICATA WOODLAND}

Ponderosa Pine / Bluebunch Wheatgrass Woodland

\section{ELEMENT CONCEPT}

Summary: This ponderosa pine woodland is one of the drier ponderosa pine woodlands found in the northern Rocky Mountains, Inter-Mountains, and extreme northwestern Great Plains of the United States and Canada . It is found on slopes with coarse soils, often with a high gravel or rock content. Pinus ponderosa is typically the only tree in the overstory, although Juniperus scopulorum may be present in the subcanopy. It forms open to moderately closed canopies. There are very few shrubs. The herbaceous layer is dominated by Pseudoroegneria spicata. Other species found in this layer are Carex filifolia, Carex inops ssp. heliophila, Koeleria macrantha, Achillea millefolium, Balsamorhiza sagittata and Hesperostipa comata (= Stipa comata). Bare mineral soil and exposed rock are common.

Environment: This community occurs mostly on steep southerly aspects. It is found on coarse soils derived from sandstone, porcillenate, or limestone (Thilenius et al. 1995). These include sandy alluvium, gravelly or sandy till, and loams with high stone content. Rock and mineral soil are commonly exposed.

In Powder River County, MT, this plant association is found on Shallow to gravel, Sandy and Silty Ecological Sites in both 10-14 and 15-19 inch precipitation zones.

Vegetation: This community is dominated by the tree and herbaceous strata. On three stands in the eastern portion of its range, Hansen and Hoffman (1988) found that total cover by understory strata was $55 \%$. Shrubs made up only $1.3 \%$ of this total. Pinus ponderosa is often the only tree in the overstory. The tree coverage can vary from open to moderately closed. In northeastern Wyoming, most of the trees were less than $15 \mathrm{~m}$ tall and 60 $\mathrm{cm}$ dbh (Thilenius et al. 1995). The herbaceous stratum is also open to moderately dense. Pseudoroegneria spicata is the dominant species. Other species that are often found in the central and eastern portions of its range are Achillea millefolium var. occidentalis, Carex filifolia, Carex inops ssp. heliophila, Koeleria macrantha, and Hesperostipa comata (= Stipa comata). In the western portion of the range of this community Festuca idahoensis may be present (Daubenmire 1952). When shrubs are present they typically include Rhus aromatica and, especially on sandy soils, Ericameria nauseosa (= Chrysothamnus nauseosus).

Dynamics: Fire likely occurred at regular intervals in this type; documentation on fire frequency is not available. Despite the widely spaced trees and relative paucity, or at least patchy distribution of fuels, this type experienced predominantly stand-replacing fire in the course of the Alkali Creek burn on the CMR Wildlife Refuge. A more typical and expected response when these conditions occur in Fire Group Two (warm, dry Pinus ponderosa habitat 
types; Fisher and Clayton 1983) is an underburn or surface fire. The Pinus ponderosa of this community type in the Bull Mountains and in the Alkali Creek study area generally bore no fire scars. This observation probably reflects the light fuels condition for this type and may also point to the exceptional Alkali Creek Fire conditions. The lack of Juniperus scopulorum in this type may be attributable to past fires killing this species and leaving the Pinus ponderosa overstory intact; this scenario has been documented by Culwell et al. (1991) in the Bull Mountains of central Montana.

GRank \& Reasons: G4 (96-02-01).

\section{ELEMENT DISTRIBUTION}

Range: This ponderosa pine woodland is one of the drier ponderosa pine woodlands found in the northern Rocky Mountains, Intermountains, and extreme northwestern Great Plains of the United States and Canada, extending from the Black Hills of South Dakota and Wyoming west to Oregon, Washington, and British Columbia.

States/Provinces: BC:S2S3, ID:S3, MT:S4, ND:S2S3?, OR:S2, SD:S4, WA:S1, WY:S3?

\section{ELEMENT SOURCES}

Authors: Drake, J. F., WCS; Heidel, B. L. MTNHP Confidence: 1 Identifier: CEGL000865

References: Bourgeron and Engelking 1994, Clausnitzer and Zamora 1987, Cooper and Pfister 1985, Cooper et al. 1987, Daubenmire 1952, Daubenmire 1970, Daubenmire and Daubenmire 1968, Driscoll et al. 1984, Hall 1973, Hansen and Hoffman 1988, Hansen et al. 1984, Hoffman and Alexander 1976, Johnson and Clausnitzer 1992, Johnson and Simon 1985, Johnson and Simon 1987, Johnston 1987, Jones 1992b, McAdams et al. 1998, McLean 1970, Pfister et al. 1977, Steele et al. 1981, Terwilliger et al. 1979a, Thilenius et al. 1995, Williams and Lillybridge 1983, Williams and Lillybridge 1985, Zamora 1983

\section{II.B.2.N.b. Temporarily flooded cold-deciduous woodland II.B.2.N.B.4. POPULUS DELTOIDES TEMPORARILY FLOODED WOODLAND ALLIANCE}

POPULUS DELTOIDES / SYMPHORICARPOS OCCIDENTALIS WOODLAND

Plains Cottonwood / Western Snowberry Woodland

\section{ELEMENT CONCEPT}

Summary: This riparian woodland community is found in the northwestern Great Plains of the United States on medium to coarse-textured alluvial soils on the floodplains of major rivers. The floodplains are both seasonally inundated and subirrigated. It is found more rarely at higher elevations in the mountains of eastern Wyoming and western South Dakota. This community is dominated by a single deciduous tree species, Populus deltoides. In some stands other species, such as Acer negundo and Fraxinus pennsylvanica, may contribute to the canopy. The tallest trees exceed $15 \mathrm{~m}$. The shrub layer is typically $0.5-1 \mathrm{~m}$ tall. It is dominated by Symphoricarpos occidentalis and commonly includes Juniperus scopulorum and Rosa spp. In Wyoming, Ericameria nauseosa (= Chrysothamnus nauseosus) is present and increases with heavy grazing. The herbaceous layer usually includes Pascopyrum smithii. Weedy species such as Melilotus officinalis, Taraxacum officinale, and Poa secunda are very common, especially in the presence of grazing. Maianthemum stellatum is abundant only where grazing is absent.

Environment: This community is found on medium to coarse-textured alluvial soils on the floodplains of major rivers. The floodplains are both seasonally inundated and subirrigated (Thilenius et al. 1995). The meandering erosional and depositional pattern of rivers maintains and influences this community along rivers (Hansen et al. 1990). It is rarely found at higher elevations in the mountains of eastern Wyoming and western South Dakota (Johnston 1987).

In Montana, this plant association occurs on major river systems of the eastern plains, with a flood cycle driven by mountain run-off and vegetation succession linked to intact hydrological processes. In Powder River County, this plant association is found in Riparian subirrigated Ecological Sites along the Powder and Little Powder Rivers. 
Vegetation: This community is typically dominated by a single deciduous tree species, Populus deltoides. In some stands other species, such as Acer negundo and Fraxinus pennsylvanica, may contribute to the canopy. The tallest trees exceed $15 \mathrm{~m}$. Populus deltoides is a pioneer species that requires moist, sparsely vegetated alluvium to become established from seed; therefore stands of this community may be considered seral, but the stage is long persistent (up to 100 years) (Girard et al. 1989). The shrub layer is typically $0.5-1 \mathrm{~m}$ tall. It is dominated by Symphoricarpos occidentalis and commonly includes Juniperus scopulorum and Rosa spp. In Wyoming, Ericameria nauseosa (= Chrysothamnus nauseosus) is present and increases with heavy grazing (Thilenius et al. 1995). The herbaceous layer usually includes Pascopyrum smithii and Elymus trachycaulus. Weedy species such as Cirsium arvense, Melilotus officinalis, Taraxacum officinale, and Poa secunda are very common, especially in the presence of grazing (Jones and Walford 1995, Thilenius et al. 1995). Maianthemum stellatum is abundant only where grazing is absent.

In Montana, stands are typically heterogeneous in vegetation age and structure as well as microtopography, because of the small-scale patterns of alluvial deposition and erosion operating over the years. In Powder River County, cottonwood communities are represented by all seral stages, from seedlings up to trees greater than 18 inches circumference. The latter stands are widely spaced, with Artemisia cana establishment if the understory is intact. In the study area, Symphoricarpos occidentalis was typically present, but was there was not a distinct shrub-layer dominant. The dominant grass was Pascopyrum smithii, followed by Nassella viridula, and replaced by Poa pratensis under disturbance. Other characteristic species include Rosa woodsii, Elymus canadensis and such generalists as Achillea millefolium. There is widespread invasion by Euphorbia esula, which has become locally abundant in many stands. Tamegrasses have been seeded or accidentally introduced into some stands, including Agropyron repens and Bromis inermis.

Dynamics: This type is found closest to the river on young, unstabilized floodplains, where it colonizes the freshly deposited alluvial substrates on the meanders of the streams and rivers. Proceeding away from the river, other later successional stages may include Populus deltoides / Fraxinus pennsylvanica Forest (CEGL000658) and Fraxinus pennsylvanica - (Ulmus americana) / Symphoricarpos occidentalis Forest (CEGL002088). As the stream continues to move away from the more recent deposits, the stand may eventually succeed to the Fraxinus pennsylvanica type, a process that could take 100 years (Girard et al. 1989).

In Montana, the climate is too dry for succession to the Fraxinus pennsylvanica type. Decadent stands may succeed to Artemisia cana (Boggs 1984).

GRank \& Reasons: G2G3 (98-06-22). The total number of occurrences is unknown. Thirteen have been documented in North Dakota, where the community is ranked S1S2?. Although no other occurrences have been documented, the community is also reported from Wyoming (S2), Colorado (S2) and may occur in South Dakota (SP). It is found in three northern Great Plains ecoregional sections. The community occurs on medium- to coarse-textured soils on the floodplains of major rivers.

Comments: Concept of the type may have come from Thilenius and Brown (1990). In eastern Montana, Hanson et al. (1990) describe a Populus deltoides / Symphoricarpos occidentalis type as a grazing-induced stage of the Populus deltoides / Cornus sericea type. This contrasts with information from Wyoming, where Thilenius et al. (1995) found that Symphoricarpos occidentalis decreases with grazing and Chrysothamnus nauseosus increases.

\section{ELEMENT DisTRIBUTION}

Range: This riparian woodland community is found in floodplains of the northwestern Great Plains of the United States, ranging from North Dakota to Colorado.

States/Provinces: CO:S2, MT:S2S3, ND:S1S2?, SD?, WY:S2

\section{ELEMENT SOURCES}

Authors: J. Drake, MCS: mod. B. L. Heidel, MTNHP Confidence: 1 Identifier: CEGL000660

References: Boggs 1984, Driscoll et al. 1984, Girard et al. 1989, Hansen et al. 1990, Johnson et al. 1990a, Johnston 1987, Jones 2001, Jones and Walford 1995, Kartesz 1999, Kittel et al. 1999, Thilenius 1970, Thilenius and Brown 1990, Thilenius and Smith 1985, Thilenius et al. 1995 


\section{SHRUBLAND}

\section{III.A.4.N.a. Lowland microphyllous evergreen shrubland III.A.4.N.A.20. ARTEMISIA TRIDENTATA SSP. WYOMINGENSIS SHRUBLAND ALLIANCE}

\section{ARTEMISIA TRIDENTATA SSP. WYOMINGENSIS / PASCOPYRUM SMITHII SHRUBLAND}

Wyoming Big Sagebrush / Western Wheatgrass Shrubland

\section{ELEMENT CONCEPT}

Summary: This Wyoming big sagebrush type is found throughout the northern Great Plains and adjacent basins, Black Hills, and Rocky Mountains of the United States. Stands occur on gently rolling uplands or upper parts of stream terraces and drainageways. Drier examples may be on more exposed slope positions. Soils are moderately deep clays, clay loam, silt loam and loam. Soil moisture conditions are relatively mesic. Soil pH ranges from 5.8 to 7.8. The vegetation contains an open short-shrub layer, approximately $0.5 \mathrm{~m}$ tall, dominated by microphyllousleaved shrubs, and a dense herbaceous layer dominated by medium-tall graminoids. Shrub cover averages between 15\% and 30\%. Artemisia tridentata ssp. wyomingensis dominates the shrub layer. The dense herbaceous layer has a canopy cover of over 75\%. Pascopyrum smithii is the leading dominant. Important associates include Koeleria macrantha, Poa secunda, and Nassella viridula (= Stipa viridula). In drier or more heavily grazed phases, Bouteloua gracilis, Hesperostipa comata (= Stipa comata), and Carex filifolia may be more common, along with the succulent Opuntia polyacantha. Forbs contribute low cover, often less than $10 \%$, and are typically of low constancy. More constant species (>50\%) include Artemisia frigida, Sphaeralcea coccinea, and Vicia americana. Grassy leaf litter covers over $75 \%$ of the ground; stones and bare soil comprise the remainder. Nonvascular plants are rare.

Environment: Stands occur on gently rolling uplands or upper parts of stream terraces and drainageways. Drier examples may be on more exposed slope positions. Soils are moderately deep clays, clay loam, silt loam and loam. Soil moisture conditions are relatively mesic. Soil pH ranges from 5.8 to 7.8 (Hirsch 1985, Hansen and Hoffman 1988, Thilenius et al. 1995).

In Montana, this widespread plant association assumes many positions and patterns depending on environmental and perhaps historical context. It prevails across Bearpaw Shale in the Missouri River drainage (DeVelice et al. 1995, Jorgenson 1979, Heidel 1997) and Bearpaw shale of extreme southeastern Montana in Carter County (Vanderhorst et al. 1998). The $\mathrm{pH}$ of soils with this plant association in Carter County ranged from 4.9-8.0. It is present at some scale in all landscapes comprised of entisol-aridisol soil complexes. Over most of the shale plains in Powder River County, it is concentrated on the steeper slopes (greater than $8 \%$ ) giving way to grassland on gentler slopes. This plant association is primarily east of the mountains, but is also documented on alluvial terraces of southwestern Montana (Cooper et al. 1995). Finally, it is found in small grassland panspots at the extreme eastern end of the state.

In Powder River County, this plant association is found in Thin Silty Ecological Sites, 10-14 in. precipitation zone. It is consistently found on steeper slopes throughout much of the County. It is not limited to steep slopes in all settings, and prevails at the extreme southwestern border of the county on Silty ecological sites, where elevation is higher. This is the case in the Ashland District of Custer National Forest, where soils supporting this plant association are characterized as loams and sandy loams (Hansen and Hoffman 1988) that seem to fall within the "Silty ecological site" definition.

Vegetation: The vegetation contains an open short-shrub layer, approximately $0.5 \mathrm{~m}$ tall, dominated by microphyllous-leaved shrubs, and a dense herbaceous layer dominated by medium-tall graminoids. Shrub cover averages between 15 and 30\% (Hirsch 1985, Hansen and Hoffman 1988, Thilenius et al. 1995). Artemisia tridentata ssp. wyomingensis dominates the shrub layer. The dense herbaceous layer has a canopy cover of over 75\%. Pascopyrum smithii is the leading dominant. Important associates include Koeleria macrantha, Poa secunda, and Nassella viridula (= Stipa viridula). In drier or more heavily grazed phases, Bouteloua gracilis, Hesperostipa comata (= Stipa comata), and Carex filifolia may be more common, along with the succulent 
Opuntia polyacantha. Forbs contribute low cover, often less than $10 \%$, and are typically of low constancy. More constant species (>50\%) include Artemisia frigida, Sphaeralcea coccinea, and Vicia americana. Grassy leaf litter covers over $75 \%$ of the ground; stones and bare soil comprise the remainder. Nonvascular plants are rare (Hirsch 1985, Hansen and Hoffman 1988, Thilenius et al. 1995).

In Powder River County, the cover of Pascopyrum smithii was high in pineland openings, up to $60 \%$ cover, while on the open plains was more typically less than $30 \%$ cover and codominant with Carex filifolia, Poa secunda, and/ or Koeleria macrantha. Commonly associated species include Artemisia frigida, Achillea millefolium, Agoseris glauca, Allium textile, Antennaria parvifolia, Commandra umbellata, Gutierrezia sarothrae, Opuntia polyacantha, Phlox hoodii, and Vicia americana. A particularly rich stand in the western end of the county included species that were scarce or absent elsewhere, including Calochortus nuttallii, Besseya wyomingensis, Linum lewisii, and Nassella viridula. Under heavy grazing pressure, the cover of exotic and increaser species like Bromus japonicus, Hedeoma hispida, Plantago patagonica, and Vulpia octoflora increases greatly.

Dynamics: Taylor and Holst (1976) refer to an "upland praririe sagebrush ecosystem" of the Ashland District and note that this sagebrush ecosystem overlaps strongly with upland grassland, appearing as an edaphic difference in places, and as a grazing disclimax in others. This dual nature of this sagebrush plant association was evident in the study area, with its status as an edaphic phenomenon indicated by the many areas in good condition. In southwestern Montana, this plant association may be a grazing disclimax (Cooper et al. 1995). See Cooper and Jean (2001) for a discussion of fire succession in the very similar Artemisia tridentata ssp. wyomingensis / Elymus lanceolatus association.

Artemisia tridentata ssp. wyomingensis is killed within prairie dog towns. In Powder River County, vegetation sampling was conducted on a bench along Buffalo Creek in what appeared to be a long-abandoned prairie dog, even though there were no signs of burrow mounds remaining. Elsewhere on the bench, Artemisia tridentata ssp. wyomingensis dominated in identical settings. In the abandoned prairie dog town, there was $50 \%$ cover of Pascopyrum smithii and 10\% cover of both Poa secunda and Bromus japonicus, with high litter accumulation (greater than $60 \%$ ). Perhaps the fertilizing and churning influence of the prairie dogs heightened productivity and impeded re-establishment of Artemisia tridentata ssp. wyomingensis in the high vegetation and/or high litter cover.

GRank \& Reasons: G4 (94-02-23).

High-ranked species: The complex vegetation mosaic patterns of this plant association within grassland and sparsely vegetated outcrops lends habitat diversity that has high wildlife values for big game and upland bird species.

Comments: This plant association is often part of a continuous gradient with the Pascopyrum smithii - Bouteloua gracilis - Carex filifolia Herbaceous Vegetation. The cover of Artemisia tridentata ssp. wyomingensis is also variable within stands, clustered around the cut-off point used in differentiating shrubland from shrub herbaceous vegetation, rather than centered greater or less than this point representing a cover value that can be discerned in remote sensing. Thus, the cover values used to define it are problemmatic.

Many of the same plant association classification questions associated with the Pascopyrum smithii - Bouteloua gracilis - Carex filifolia Herbaceous Vegetation are also present for this plant association: 1) the interchangeability and ecological equilivence of Pascopyrum smithii and Elymus lanceolatus and the similar needlegrass species-pair has not been analyzed in detail. They sort by latitude in their distribution and their tendency to have different environmental modes where they occur together warrants extended documentation. We did note that Elymus lanceolatus is uncommon in Powder River County compared to Pascopyrum smithii; the former species is most common on overflow outwashes and panspots in the County. However, Elymus lanceolatus appeared to be the dominant or codominant in at least some of the Carter County vegetation study sites (Vanderhorst et al. 1998) and further investigation is needed into their ecological equivalency. 2). The question of delimiting the Pascopyrum smithii dominance from the Hesperostipa comata - Bouteloua gracilis dominance becomes secondary where Artemisia tridentata ssp. wyomingensis cover is high. The fine textured soils preclude much Hesperostipa comata in the study area. 3). There are different co-dominants with Pascopyrum smithii, with or without Bouteloua gracilis, Carex filifolia, Buchloe dactyloides, and Poa secunda. Given the current concept of this type, they all fit 
within the type, but not all of their environmental characteristics fit. The codominance of Buchloe dactyloides with Pascopyrum smithii in Artemisia tridentata ssp. wyomingensis shrubland, as documented on BLM-administered lands in much of Powder River County, has not been well-documented in the northern Great Plains.

\section{ELEMENT DisTRIBUTION}

Range: This Wyoming Big Sagebrush type is found throughout the northern Great Plains and adjacent basins, Black Hills, and Rocky Mountains of the United States, particularly in Colorado and Wyoming.

In Montana, it is most extensive on shale plains in counties along the Missouri River (DeVelice et al. 1995), as well as those of Carter County in the southeastern corner (Vanderhorst et al. 1998). But it is present throughout eastern Montana where there are fine-textured entisol and aridisol soils, as found on Ashland and Sioux Districts of Custer National Forest (Hansen and Hoffman 1988). In Powder River County, this plant association is present everywhere the topography is dissected. It is especially extensive in the extreme southwestern corner of the county.

States/Provinces: CO:S3S4, MT:S?, ND?, WY:S?

\section{ELEMENT SOURCES}

Authors: D. Faber-Langendoen, WCS; mod. B. L. Heidel, MTNHP Confidence: 2 Identifier: CEGL001047 References: Baker 1982b, Baker 1983c, Baker and Kennedy 1985, Bear Creek Uranium Mine Application n.d., Bourgeron and Engelking 1994, Cooper et al. 1995, Cooper and Jean 2001, Cotter-Ferguson Project n.d., DeVelice et al. 1995, Driscoll et al. 1984, Earth Resource Technology n.d., Ellis and Hackney 1981, Francis 1983, Hansen and Hoffman 1988, Hansen et al. 1980, Hansen et al. 1984, Hirsch 1985, Keammerer 1987, Skull Point Mine Application n.d., Skull Point Mine Permit Renewal n.d., Strong 1980, Sweetwater Uranium Project 1978, Thilenius et al. 1995, Tiedemann et al. 1987, Vanderhorst et al. 1998

ARTEMISIA TRIDENTATa SSP. WYOMINGENSIS / PSEUdoroegneria SPICATA SHRUbland Wyoming Big Sagebrush / Bluebunch Wheatgrass Shrubland

\section{ELEMENT CONCEPT}

Summary: This is a widespread Wyoming Big Sagebrush shrub type, extending from the western side of the Great Plains on the east to British Columbia on the west, and south as far as northern Nevada. Stands of this type occupy loamy soils (often with coarse fragments) derived from a variety of parent materials, on middle and lower slopes and in draws. Shrubs are dense and form a canopy with at least $25 \%$ cover. Artemisia tridentata ssp. wyomingensis contributes the most cover to the shrub layer and is often the only shrub present. The height of the sagebrush ranges fromabout $35 \mathrm{~cm}$ tall in the eastern part of the range toabout $1 \mathrm{~m}$ tall in the western part. Chrysothamnus spp. often are present as well. Pseudoroegneria spicata contributes more cover to the herbaceous layer than does any other native species, and Poa secunda usually is present. Stands in the eastern part of the geographic range often include Gutierrezia sarothrae, Artemisia frigida, Bouteloua gracilis, and Koeleria macrantha. Many stands of this community may result from grazing in stands of Artemisia tridentata ssp. wyomingensis / Pseudoroegneria spicata Shrub Herbaceous Vegetation (CEGL001535). Grazing increases the cover and density of shrubs and often decreases the cover of grasses, especially of Pseudoroegneria spicata. Stands no doubt exist, though, that do not result from grazing. Such stands are likely found in draws and other places on the landscape where soil moisture is sufficient to support a dense shrub canopy, and may represent only a small area on the landscape.

Environment: Stands of this type occupy loamy soils (often with coarse fragments) derived from a variety of parent materials, on middle and lower slopes and in draws. The close relationship between this association and Artemisia tridentata ssp. wyomingensis / Pseudoroegneria spicata Shrub Herbaceous Vegetation (CEGL001535) suggests that stands of this type occupy loamy soils (often with coarse fragments) derived from a variety of parent materials, on middle and lower slopes and in draws.

Vegetation: Throughout the geographic range of this type, Artemisia tridentata ssp. wyomingensis dominates a shrub layer that has at least 25\% canopy cover. Rabbitbrushes (Chrysothamnus spp.) often are present as well. Pseudoroegneria spicata contributes more cover to the herbaceous layer than does any other native species, and Poa secunda usually is present. Stands in the eastern part of the geographic range often include Gutierrezia 
sarothrae, Artemisia frigida, Bouteloua gracilis, and Koeleria macrantha. The height of the sagebrush ranges from about $35 \mathrm{~cm}$ tall in the eastern part of the range to about $1 \mathrm{~m}$ tall in the western part (Hironaka et al. 1983).

GRank \& Reasons: G5? (96-02-01).

Comments: Many stands of this association may be derived by grazing of Artemisia tridentata ssp. wyomingensis / Pseudoroegneria spicata Shrub Herbaceous Vegetation (CEGL001535). It may be preferrable to first combine these two types, and then split them geographically. The occurrences from the Great Plains west as far as northwestern Colorado, western Wyoming, and western Montana might belong to one type characterized by the presence of Bouteloua spp., Carex filifolia, Koeleria macrantha, Gutierrezia sarothrae, Artemisia frigida, and Opuntia polyacantha, and by the absence of Achnatherum thurberianum (= Stipa thurberiana). The occurrences from southern Idaho, northern Nevada, eastern Oregon, eastern Washington, and British Columbia could belong to a different type characterized by the presence of Achnatherum thurberianum, and by the absence of the other species listed above. The separation between these two types probably would occur in Idaho. Additional research will be required to clarify this issue.

\section{ELEMENT DisTRIBUTION}

Range: This is a widespread Wyoming Big Sagebrush shrub type, extending from the western side of the Great Plains on the east to British Columbia on the west, and south as far as northern Nevada.

\section{States/Provinces: BC:S2, CO:S3?, ID:S?, MT:S5?, ND:S2S3?, NV:S?, UT:S4S5?, WA:S?, WY:S?}

\section{Element Sources}

Authors: B. Johnston, mod. D. Faber-Langendoen, WCS Confidence: 2 Identifier: CEGL001009

References: Blackburn 1967, Blackburn et al. 1968a, Blackburn et al. 1968b, Blackburn et al. 1969a, Blackburn et al. 1969c, Blackburn et al. 1971, Bourgeron and Engelking 1994, Brotherson and Brotherson 1981, Cooper et al. 1995, Daubenmire 1970, DeVelice et al. 1991, Driscoll et al. 1984, Hall 1973, Heinze et al. 1962, Hironaka et al. 1983, Johnston 1987, Knight et al. 1987, Lewis 1975, McLean 1970, Moretti 1979, Moretti and Brotherson 1982, Mueggler and Stewart 1980, Poulton 1955, Tisdale 1947

\section{III.A.4.N.c. Temporarily flooded microphyllous shrubland III.A.4.N.C.2. ARTEMISIA CANA TEMPORARILY FLOODED SHRUBLAND ALLIANCE}

ARTEMisia CANA / PASCOPYRUM SMITHI SHRUbLAND

Silver Sagebrush / Western Wheatgrass Shrubland

\section{ELEMENT CONCEPT}

Summary: This silver or coaltown sagebrush shrubland is found in the northwestern Great Plains and Rocky Mountains of the western United States. Stands occur on flat alluvial deposits on floodplains, terraces or benches, or alluvial fans. The soils are moderately deep to deep and either silt loam, clay loam, or sandy loam. Flooding may occur periodically and this tends to retard soil development. This community is dominated by a combination of shrubs and graminoids. The total vegetation cover is moderate. The tallest and most conspicuous stratum in this community is a shrub layer that is usually $0.6-1.2 \mathrm{~m}$. Artemisia cana is the dominant in this layer and may be accompanied by Symphoricarpos occidentalis. Also present are shorter shrubs such as Artemisia frigida, Krascheninnikovia lanata, Rosa woodsii, and Gutierrezia sarothrae. The most abundant graminoid is Pascopyrum smithii. This species is typically $0.5-1.0 \mathrm{~m}$ tall. It is often accompanied by Nassella viridula and sometimes Koeleria macrantha, Poa pratensis, and Hesperostipa comata (= Stipa comata). Bouteloua gracilis is the most abundant short graminoid. Typical forb constituents of this community are Achillea millefolium, Gaura coccinea, Sphaeralcea coccinea, and Lactuca tatarica var. pulchella.

Environment: This community occurs on flat alluvial deposits on floodplains, terraces or benches, or alluvial fans. The soils are moderately deep to deep (USFS 1992) and either silt loam, clay loam, or sandy loam (Johnston 1987, Hansen and Hoffman 1988). The soils may have moderate salt content (Hanson and Whitman 1938).

Flooding occurs periodically and this tends to retard soil profile development (Hirsch 1985). 
In Powder River County, this plant association is found on Overflow Ecological Sites in the 10-15 and 15-19 inch precipitation zones. It is the prevailing vegetation along major river valleys.

Vegetation: This community is dominated by a combination of shrubs and graminoids. The total vegetation cover is typically moderate, but depends on frequency of flooding. The tallest and most conspicuous stratum is a shrub layer that is usually 0.6-1.2 m (Hansen and Hoffman 1988). In 14 stands in western North Dakota shrubs averaged $28 \%$ canopy cover, graminoids $59 \%$, and forbs $2 \%$ (USFS 1992). Stands in Nebraska often have less than $15 \%$ cover. The variation in soils within and between stands of this community results in variable species composition. Artemisia cana is the dominant shrub. Symphoricarpos occidentalis is frequently present. There are also shorter shrubs such as Artemisia frigida, Krascheninnikovia lanata, Rosa woodsii, and Gutierrezia sarothrae. The most abundant graminoid is Pascopyrum smithii. This species is typically $0.5-1.0 \mathrm{~m}$ tall. It is often accompanied by Nassella viridula and sometimes Koeleria macrantha, Poa pratensis, and Hesperostipa comata (= Stipa comata). Bouteloua gracilis is the most abundant short graminoid. Typical forb constituents of this community are Achillea millefolium, Gaura coccinea, Sphaeralcea coccinea, and Lactuca tatarica var. pulchella.

Dynamics: Periodic flooding occurs in many stands of this community.

GRank \& Reasons: G4 (96-02-01).

Comments: See Steinauer and Rolfsmeier (2000) for a description of the stands in Nebraska.

\section{ELEMENT DiSTRIBUTION}

Range: This silver or coaltown sagebrush shrubland is found in the northwestern Great Plains and Rocky Mountains of the western United States, ranging from Montana and North Dakota, south to Nebraska.

States/Provinces: MT:S4, ND:S2S3?, NE:S?, SD:SU

\section{ELEMENT SOURCES}

Authors: Drake, J. F., WCS; mod. B. L. Heidel, MTNHP Confidence: 1 Identifier: CEGL001072

References: Bourgeron and Engelking 1994, Driscoll et al. 1984, Hansen and Hoffman 1988, Hansen et al. 1984, Hansen et al. 1991, Hansen et al. 1995, Hanson and Whitman 1938, Hirsch 1985, Johnston 1987, Nelson 1961, Steinauer and Rolfsmeier 2000, USFS 1992

\section{III.B.2.N.d. Temporarily flooded cold-deciduous shrubland III.B.2.N.D.6. SALIX (EXIGUA, INTERIOR) TEMPORARILY FLOODED SHRUBLAND ALLIANCE}

SALIX EXIGUA TEMPORARILY FLOODED SHRUBLAND

Coyote Willow Temporarily Flooded Shrubland

\section{ELEMENT CONCEPT}

Summary: This willow shrubland community is found along rivers and streams at lower elevations throughout the northwestern United States and Great Plains. This type is an early successional stage that occurs on recently flooded riparian areas. Stands occur most commonly on alluvial sand, but silt, clay, or gravel may also be present. Salix exigua is the dominant canopy species (Salix interior or intermediates of the two willow species may be present in the eastern part of the range). It can form dense stands up to $4 \mathrm{~m}$ tall, but there are often patches where the shrub layer is absent. Seedlings and small saplings of Populus deltoides and Salix amygdaloides may be present. The herbaceous cover is sparse to moderate, but rarely exceeds $30 \%$. Species present include Cenchrus longispinus, Polygonum lapathifolium, Schoenoplectus americanus (= Scirpus americanus), Triglochin maritima, and Xanthium strumarium. The composition of this community, especially the herbaceous layer, varies from year to year with succession or renewed disturbance.

Environment: This community is found on recently deposited or disturbed alluvial material. The parent material is alluvial sand, although silt, clay, or gravel may be present. Soil development is poor to absent. 
Vegetation: This community is dominated by shrubs, generally between 2 and $4 \mathrm{~m}$ tall. The most common of these is Salix exigua (Salix interior or intermediates of the two willow species may be present in the eastern part of the range). Salix irrorata and saplings of Populus deltoides or Salix amygdaloides are also frequently found in the shrub layer. This stratum can have moderate to high stem density in the community as a whole. The species in the shrub layer do not form a closed canopy, allowing significant light to reach the ground layer. There are often patches where the shrub layer is absent. The herbaceous cover is sparse to moderate, but rarely exceeds $30 \%$. Older stands and places with less competition from the shrubs have greater herbaceous cover. The composition of the herbaceous layer can vary greatly. Species that are often found in this community are Cenchrus longispinus,

Polygonum lapathifolium, Schoenoplectus americanus (= Scirpus americanus), Triglochin maritima, and Xanthium strumarium.

Dynamics: This type originates after flash floods that create new deposits or scour existing alluvial material. This community is a primary or early secondary community and requires floods to create new areas on which it can develop. Once established, this community may not exist for more than 10-20 years before it is replaced by a later seral stage.

GRank \& Reasons: G5 (99-05-06)

Comments: This type may be an early successional shrubland that develops into Salix exigua / Mesic Graminoids Shrubland (CEGL001203), or the two types may be essentially synonymous. This plant association occupies a wide geographic range. The range of this type was reviewed and it was split into eastern, Salix interior Temporarily Flooded Shrubland (CEGL008562), and western components. The western stands may all be composed of Salix exigua (sensu stricto) and Great Plains stands may contain either Salix exigua, Salix interior, or intermediates of the two willow species, the Salix exigua being an entirely Great Plains and eastwardly distributed species (Kartesz 1999).

\section{ELEMENT DisTRIBUTION}

Range: This sandbar willow shrubland community is found along rivers and streams at lower elevations throughout the northwestern United States and Great Plains, ranging sporadically from Oklahoma northwest to the Dakotas and Manitoba, and west to Washington. Part of this type's former range in the Great Plains and eastward is actually occupied, at least in part, by Salix interior [see Salix interior Temporarily Flooded Shrubland (CEGL008562)].

States/Provinces: ID:S3?, MB:S?, MT:S5, ND:S?, NE:S4S5, OK:S?, OR:S1, SD:S2, WA:S?, WY:S3Q

\section{ELEMENT SOURCES}

Authors: J.F. Drake, WCS Confidence: 1 Identifier: CEGL001197

References: Bellah and Hulbert 1974, Bourgeron and Engelking 1994, Driscoll et al. 1984, Evenden 1990, Foti et al. 1994, Hansen et al. 1989, Hansen et al. 1991, Hansen et al. 1995, Hoagland 1998c, Hoagland 2000, Kartesz 1999, Kittel and Lederer 1993, Kovalchik 1987, Phillips 1977, Steinauer 1989, Steinauer and Rolfsmeier 2000, Wilson 1970

\section{III.B.2.N.D.20. SYMPHORICARPOS OCCIDENTALIS TEMPORARILY FLOODED SHRUBLAND ALLIANCE}

\section{SYMPHORICARPOS OCCIDENTALIS SHRUBLAND}

Western Snowberry Shrubland

\section{ELEMENT CONCEPT}

Summary: This western snowberry shrubland is found in the western tallgrass and northern Great Plains of the United States and Canada. Stands occur in mesic depressions and swales, typically surrounded by upland grassland communities. The soils are silts and loams. This type has three distinct vegetation layers, a shrub layer (approximately $80 \mathrm{~cm}$ tall), a graminoid-dominated layer (approximately $30 \mathrm{~cm}$ tall), and a forb-dominated layer $(<20 \mathrm{~cm}$ tall). Symphoricarpos occidentalis is the predominant species in the shrub layer and at times forms almost monospecific stands. Rosa woodsii commonly occurs interspersed with the Symphoricarpos occidentalis. Other shrubs, such as Rhus aromatica and Prunus virginiana, often occur as thickets on the fringe of this 
community. Rhus aromatica and Prunus virginiana can reach $2 \mathrm{~m}$ or more. The herbaceous layer is poorly represented where the shrubs are dense, although Poa pratensis occurs in many stands. Common forbs include Artemisia ludoviciana, Solidago spp., and Achillea millefolium. Vines, such as Parthenocissus vitacea, are often found climbing through the shrubs. This type is frequently observed in heavily grazed meadows and prairies.

Environment: This community is found in mesic swales, depressions, ravines and floodplains. Some examples of this community experience intermittent and brief flooding. The soils are fertile and well-drained to imperfectly drained silts and loams. The upper soil horizon is usually deep, although a thin layer of sand may be present if the site has been recently flooded (Jones and Walford 1995).

Vegetation: Throughout its range this community is dominated by shrubs approximately $1 \mathrm{~m}$ tall. Shrub cover is typically greater than $50 \%$, and in places it can approach $100 \%$. These shrubs form dense clumps that exclude most other species. Symphoricarpos occidentalis is the most common shrub, but Rhus aromatica (or Rhus trilobata) and Prunus virginiana can be locally abundant and can grow to 2-3 $\mathrm{m}$ in places. Toxicodendron rydbergii may also be present. Herbaceous species and smaller shrubs are most abundant at the edges of this community and in gaps between the clumps of taller shrubs where the shading is less complete. Rosa woodsii is a typical smaller shrub. Common graminoids include Pascopyrum smithii and Poa pratensis. Achillea millefolium, Artemisia ludoviciana, Galium boreale, and Solidago spp. are common forbs of this community. Woody vines sometimes occur, including Parthenocissus vitacea.

Dynamics: Stands may occasionally be flooded (Jones and Walford 1995). Symphoricarpos occidentalis seems to thrive in disturbed areas (Hansen and Hoffman 1988), especially those subject to disturbance by fire and cattle grazing.

GRank \& Reasons: G4G5 (96-02-01). This type is common throughout the northern Great Plains. Historically, it may never have been very extensive. It has been observed to grow out from forest or woodland edges and shade out the grasses. It is tolerant of both grazing and fire (Hansen and Hoffman 1988), and is under no threat from human activities. In some cases, heavily grazed pastures may favor this types. Many examples are somewhat weedy; thus the type is not demonstrably secure.

Comments: This type often occurs in heavily disturbed areas in conjunction with exotic species such as Poa pratensis and Cirsium arvense. Because it occurs in mesic swales, depressions, ravine bottoms and floodplains, some stands are occasionally flooded whereas others are just very moist. Thus it tends to fall on both sides of the upland/wetland division.

\section{ELEMENT DisTRIBUTION}

Range: This western snowberry shrubland is found in the western tallgrass and northern Great Plains of the United States and Canada.

States/Provinces: CO:S3, IA?, MB?, MT:S4S5, ND:S4?, NE:S4, SD:SU, SK:S?, WY:SR

\section{ELEMENT SOURCES}

Authors: Drake, J. F., WCS Confidence: 3 Identifier: CEGL001131

References: Bourgeron and Engelking 1994, Christy 1973, Clark 1977b, Clark et al. 1980, Driscoll et al. 1984, Hansen and Hoffman 1988, Hansen et al. 1984, Hansen et al. 1991, Hansen et al. 1995, Johnston 1987, Jones 1992b, Jones and Walford 1995, Kittel et al. 1994, Kittel et al. 1999, McAdams et al. 1998, Meyer 1985, Steinauer and Rolfsmeier 2000 


\section{III.B.3.N.a. Extremely xeromorphic deciduous subdesert shrubland without succulents

\author{
III.B.3.N.A.14. SARCOBATUS VERMICULATUS SHRUBLAND ALLIANCE
}

Sarcobatus Vermiculatus / PSEUdoroegneria SPICATa SHRUbland

Black Greasewood / Bluebunch Wheatgrass Shrubland

\section{ELEMENT CONCEPT}

Summary: This greasewood community is found in the badlands regions of the northwestern Great Plains. Stands are found on weakly consolidated sedimentary rocks, where eroded slopes contain interbedded clay and silt shales.

Slopes range from $0-80 \%$, and average about $35-40 \%$, with a southwest- to southeast-facing aspect. A thin crust of highly saline salt $1-5 \mathrm{~cm}$ in depth may form on the surface. Soil $\mathrm{pH}$ is around 8.0. Stands have a sparse to moderate woody layer (15-40\% cover) dominated by the deciduous, facultative halophytic shrub Sarcobatus vermiculatus. Other characteristic shrubs and dwarf-shrubs may include Artemisia tridentata, Atriplex canescens, Ericameria nauseosa (= Chrysothamnus nauseosus), and Gutierrezia sarothrae. The herbaceous layer ranges from absent to moderately sparse cover $(<25 \%)$ of scattered tall and medium-tall bunch grasses, such as Pseudoroegneria spicata, Achnatherum hymenoides (= Oryzopsis hymenoides), and the sod grass Bouteloua gracilis. Annual grasses, especially the exotic Bromus tectorum and Bromus japonicus, may be present. Forbs are sparse, except on disturbed, weedy sites. Forb species may include Eriogonum pauciflorum, Suaeda calceoliformis, or Sphaeralcea coccinea. Occasionally, cacti, such as Opuntia fragilis or Opuntia polyacantha, may also be present.

Environment: Stands occur in the badlands regions of the northwestern Great Plains, where they are found on weakly consolidated sedimentary rocks. The badland topography is composed of outcrops of parallel beds of clay and silt shales, interspersed in some regions with lignite (coal) seams of varying thickness, massive outcroppings of sandstone strata, and colluvial talus of clay, silt and fragments of sandstone (Brown 1971). This community is found on the interbedded clay and silt shales. Slopes range from 0 to $80 \%$, and average about $35-40 \%$, with a southwest- to southeast-facing aspect. On steeper slopes, this community is found on residual interbedded clays and silts, with occasional bands of lignite that are from several centimeters to over a meter in thickness, and stands are usually 0.5 ha in size. On more gentle slopes, they are found on alluvial materials of stream terraces and may range in size up to 4 ha or more. A thin crust of highly saline salt 1 to $5 \mathrm{~cm}$ in depth may form on the surface. These crusts form in places where substantial movement of subsurface water accumulates high concentrations of salts and sodium near the surface through high evaporation rates (Brown 1971). The porous lignite seams may cause subsurface water to move horizontally to the surface on the hillsides (Hansen and Hoffman 1988). The upper and lower soil horizons contain concentrations of sodium salt of 9.1 to $12.00 \mathrm{me} / 100 \mathrm{~g}$ (Brown 1971). Soil pH is around 8.0.

Vegetation: Stands have a sparse to moderate woody layer (15-40\% cover) dominated by the deciduous, facultative halophytic shrub Sarcobatus vermiculatus. Other characteristic shrubs and dwarf-shrubs may include Artemisia tridentata, Atriplex canescens, Ericameria nauseosa (= Chrysothamnus nauseosus), and Gutierrezia sarothrae. The herbaceous layer ranges from absent to moderately sparse cover $(<25 \%)$ of scattered tall and medium-tall bunch grasses, such as Pseudoroegneria spicata, Achnatherum hymenoides (= Oryzopsis hymenoides), and the sod grass Bouteloua gracilis. Annual grasses, especially the exotic Bromus tectorum and Bromus japonicus may be present. Forbs are sparse, except on disturbed, weedy sites. Forb species may include Eriogonum pauciflorum, Suaeda calceoliformis, or Sphaeralcea coccinea. Occasionally, cacti, such as Opuntia fragilis or Opuntia polyacantha, may also be present (Brown 1971, Hansen and Hoffman 1988).

Dynamics: Natural disturbances include ongoing erosion of badlands topography, and, where stands are near streams, occasional flash floods.

GRank \& Reasons: G3 (99-09-28). This type is restricted to Badlands topography in the northern Great Plains, rarely exceeding 4-5 ha in size. Sites are not particularly threatened, but site requirements are very specialized (highly salty subsurface soils) and localized. 


\section{ELEMENT DisTRIBUTION}

Range: This community is found in the badlands regions of southeastern Montana and western South Dakota, and possibly in northeastern Wyoming and western North Dakota.

States/Provinces: MT:S3, ND:S?, SD:S?, WY?

ELEMENT SOURCES

Authors: D. Faber-Langendoen, WCS Confidence: 1 Identifier: CEGL001367

References: Bourgeron and Engelking 1994, Brown 1971, Driscoll et al. 1984, Hansen 1985, Hansen and Hoffman 1988 


\section{HERBACEOUS VEGETATION}

\section{V.A.5.N.a. Tall sod temperate grassland V.A.5.N.A.3. ANDROPOGON HALLII HERBACEOUS ALLIANCE}

ANDROPOGON HALLII - CALAMOVILFA LONGIFOLIA HERBACEOUS VEGETATION

Sand Bluestem - Prairie Sandreed Herbaceous Vegetation

\section{ELEMENT CONCEPT}

Summary: This sand prairie community is found in the northern and central Great Plains of the United States and Canada. Stands are found on sandy deposits, usually on gentle to moderate slopes, ranging from stabilized rolling to choppy sand dunes. The soil is sand, loamy sand, or sandy loam, often erodible, and somewhat poorly developed. This community is dominated by moderately widely spaced mid to tall grasses. The most abundant species are Andropogon hallii and Calamovilfa longifolia. Other graminoids that may be found in this community include Bouteloua gracilis, Bouteloua hirsuta, Carex duriuscula, Carex filifolia, Carex inops ssp. heliophila, Cyperus schweinitzii, Eragrostis trichodes, Hesperostipa comata (= Stipa comata), Koeleria macrantha, Muhlenbergia pungens, Redfieldia flexuosa, and Schizachyrium scoparium. Forbs and shrubs are a minor component of the total vegetation. Characteristic forbs include Chenopodium subglabrum, Chamaesyce serpyllifolia, Helianthus pauciflorus, Helianthus petiolaris, Lappula occidentalis var. occidentalis, Liatris punctata, Lithospermum incisum, Lygodesmia juncea, Monarda punctata, Oenothera rhombipetala, Penstemon haydenii (in Nebraska), and Psoralidium lanceolatum. Artemisia frigida and Yucca glauca are the most common shrubs, especially on wind-blown dune crests and choppy slopes in Nebraska sandhills. In southeastern North Dakota, a subtype containing tallgrass species may be distinct; species include Andropogon gerardii, Symphyotrichum ericoides (= Aster ericoides), Lithospermum canescens, Solidago nemoralis, and Sporobolus heterolepis.

In Montana, this plant association is uncommon as a widely-scattered feature associated with active wind erosion. Montana in general does not have the choppy dune systems that characterize the Nebraska Sandhills and the glacial lake sandhills elsewhere in the northern Great Plains, where they are more extensive and well-developed. This plant association is at the "rim" of blowouts within the most similar of Montana landscapes, i.e., the Medicine Lake sandhills of Sheridan County. But, this type is so small and narrow a vegetation band that it was not included in the description of plant associations here. There is more habitat for it in the unglaciated sedimentary plains of the Fort Union Formation at localized erosion features associated with sandstone outcrops, though widely-scattered and in small pockets. In Powder River County, this plant association is uncommon in places with sandstone outcrops as found in at least the eastern end of the County.

Environment: This community is usually found on sandy deposits, such as dunes, with gentle to moderate slopes (Johnston 1987). The soil is sand, loamy sand, or sandy loam and often erodible. Hirsch (1985) reported that stands of this type in southwestern North Dakota were small, generally less than 0.05 ha.

In Montana and Powder River County, this plant association is restricted to active wind erosion features in the Sands ecological sites, most often in the sideslopes of a blowout but also at the rim. It occurs in Powder River County within the 10-14 in ppt. zone, and at higher precipitation levels elsewhere.

Vegetation: This community is dominated by moderately widely spaced mid to tall grasses. The most abundant species are Andropogon hallii and Calamovilfa longifolia. Other graminoids that may be found in this community include Bouteloua gracilis, Bouteloua hirsuta, Carex duriuscula (= Carex eleocharis), Carex filifolia, Carex inops ssp. heliophila, Cyperus schweinitzii, Eragrostis trichodes, Hesperostipa comata (= Stipa comata), Koeleria macrantha, Muhlenbergia pungens, Redfieldia flexuosa, and Schizachyrium scoparium. Forbs and shrubs are a minor component of the total vegetation. Characteristic forbs include Chenopodium subglabrum, Chamaesyce serpyllifolia (= Euphorbia serpyllifolia), Helianthus pauciflorus, Helianthus petiolaris, Lappula occidentalis var. occidentalis, Liatris punctata, Lithospermum incisum, Lygodesmia juncea, Monarda punctata, Oenothera rhombipetala, Penstemon haydenii (in Nebraska), and Psoralidium lanceolatum. Artemisia frigida and Yucca glauca are the most common shrubs, especially on wind-blown dune crests and choppy slopes in Nebraska 
sandhills (Steinauer and Rolfsmeier 2000). On eroding parts of the Nebraska Sandhills a number of different species may occur, including Chamaesyce geyeri, Chamaesyce missurica, Chenopodium berlandieri,

Chenopodium pratericola, Cycloloma atriplicifolium, Erigeron bellidiastrum, Eriogonum annuum, Froelichia floridana var. campestris, Ipomopsis longiflora, and Linum rigidum. Redfieldia flexuosa is common in blowouts (Steinauer and Rolfsmeier 2000). In southeastern North Dakota, a subtype containing tallgrass species may be distinct; species include Andropogon gerardii, Symphyotrichum ericoides (= Aster ericoides), Lithospermum canescens, Solidago nemoralis, and Sporobolus heterolepis (Burgess 1965). In southwestern Kansas, Calamovilfa gigantea may be present (Lauver et al. 1999).

In Montana, the vegetation is dominated or co-dominated by Andropogon hallii and Calamovilfa longifolia. Sometimes they sort in separate small bands by microhabitat and succession, but they are more often intermixed. Other graminoides that are often present include Achnatherum hymenoides, Sporobolus cryptandrus and Hesperostipa comata. Forbs typically include Ambrosia psilostachya, Eriogonum annuum, Helianthus petiolaris, Lygodesmia juncea, Psoralidium lanceolatum, and Tradescantia occidentalis.

Dynamics: Blowouts may occur in this community type, leading to bare soils or subsoils. Blowouts may be related to severe droughts and windstorms, and may occur in conjunction with grazing pressures or fires that reduce the ability of the vegetation cover to stabilize the sand. Andropogon hallii - Carex inops ssp. heliophila Herbaceous Vegetation (CEGL001466) may be an early successional phase on blowouts, at least in the northern states (Burgess 1965). Blowouts may subsequently develop into this type where sands have been stabilized and vegetation cover and diversity are high.

GRank \& Reasons: G4G5 (00-03-24). This type has a relatively restricted distribution in terms of site characteristics, but has a wide distribution in the northern Great Plains. The community is reported from 7 ecoregional sections in Kansas, Nebraska, Montana, South Dakota, North Dakota, Manitoba, and Saskatchewan. Stands are typically less than a few hectares in size in the northern parts of the range, but can be quite extensive in the Nebraska Sandhills. Total coverage is over 100,000 acres. Threats are not known.

High-ranked species: This plant association or closely related ones harbor many S1 and S2 plant species in Montana, including Chenopodium subglabrum, Cryptantha fendleri, Cyperus schweinitzii, Dalea villosa var villosa, Mentzelia nuda, Psoralea lanceolata, and possibly others.

Comments: Stands in this association may vary from north to south and east to west. More northern stands may have higher dominance by Carex filifolia or Carex inops ssp. heliophila. Distinctions between this type and Andropogon hallii - Carex inops ssp. heliophila Herbaceous Vegetation (CEGL001466) are not entirely clear. Note that Looman (1980) describes this type for Manitoba, but these northern stands also contain Carex siccata (= Carex foenea), Danthonia spicata, and Festuca ovina. Currently the North Dakota Heritage Program restricts this type primarily to the tallgrass prairie region of the state, where sands are deep, as described in part by Burgess (1965); however, it is reported farther west in southwestern North Dakota (Hirsch 1985) and Montana. Rangewide application of this type needs further review. In Minnesota, relatively small Calamovilfa longifolia-dominated patches can occur in dry sand prairies or barrens, particularly on crests of dunes, but these are treated as part of Schizachyrium scoparium - Hesperostipa spartea - Bouteloua (curtipendula, gracilis) Sand Herbaceous Vegetation (CEGL005204). Andropogon hallii does not occur as a native species in Minnesota. Steve Kettler (pers. comm. 1998) indicated that this association does not occur in Colorado (although they once tracked it). All of their sandhill types contain Artemisia filifolia and are classified (or will be reclassified) as Artemisia filifolia / Andropogon hallii Shrubland (CEGL001459). NRCS range site descriptions state that abundance of Artemisia filifolia should be low, but Kettler thinks it is always present, otherwise the vegetation and environment are similar. He suggested that the presence or absence of Artemisia filifolia seems to make a good split between the southern (Colorado and south and east) and the northern (Nebraska and north) sandhills.

\section{ELEMENT DiSTRIBUTION}

Range: This sand prairie community is found in the northern and central Great Plains of the United States and Canada, ranging from Manitoba and Saskatchewan, south to Kansas.

In Montana, it is localized within the aeolian sand deposits of the Medicine Lake Sandhills. There exists appropropriate habitat in the unglaciated sedimentary plains at localized erosion features associated with sandstone 
outcrops, though widely-scattered and in small pockets.

States/Provinces: KS:S2S3, MB:S?, MT:S?, ND:S?, NE:S5, SD:S?, SK:S?

\section{ELEMENT SOURCES}

Authors: Drake, J. F., WCS; mod. B. L. Heidel, MTNHP Confidence: 1 Identifier: CEGL001467

References: Bourgeron and Engelking 1994, Bruner 1931, Burgess 1965, Driscoll et al. 1984, Hirsch 1985, Hoagland 1998a, Johnston 1987, Lauver et al. 1999, Looman 1980, Ramaley 1939b, Soil Conservation Service 1978, Steinauer 1989, Steinauer and Rolfsmeier 2000, Tolstead 1941, Tolstead 1942

ANDROPOGON HALLII - CAREX INOPS SSP. HELIOPHILA HERBACEOUS VEGETATION

Sand Bluestem - Sun Sedge Herbaceous Vegetation

\section{ELEMENT CONCEPT}

Summary: This sand bluestem prairie community type is found in restricted areas of the northern Great Plains of the United States. Stands occur on gently to steeply sloping terrain with sand or sandy loam soil. In Montana, stands occur on slopes of any aspect, but north is the least likely. In North Dakota, they occur on steep, choppy sands. The vegetation is very open, ranging from $15-50 \%$ cover. The taller herbaceous stratum of this community is dominated by Andropogon hallii, with associates of Calamovilfa longifolia, Hesperostipa comata (= Stipa comata), and Sporobolus cryptandrus. In southeastern North Dakota Koeleria macrantha, Redfieldia flexuosa, and Hesperostipa spartea (= Stipa spartea) are present at low abundance. The lower herbaceous stratum is dominated by Carex spp., especially Carex inops ssp. heliophila. Other species that may be present are Artemisia frigida, Carex filifolia, Carex duriuscula, Dalea villosa, and Yucca glauca. Key diagnostic characteristics include the choppy sand dune habitat, the very open structure of the vegetation, dominance by Andropogon hallii with Carex inops ssp. heliophila and the presence of early successional species, such as Redfieldia flexuosa.

Environment: This type is found on gentle to steep sloping terrain with sand or sandy loam soil. In Montana, it can occur on slopes of any aspect but north is the least likely (MTNHP 1988). In North Dakota, it occurs on steep, choppy sands (Heidel 1984a).

Vegetation: The vegetation is very open, ranging from 15-50\% cover (Burgess 1965). The taller herbaceous stratum of this community is dominated by Andropogon hallii, with associates of Calamovilfa longifolia, Hesperostipa comata (= Stipa comata), and Sporobolus cryptandrus. In southeastern North Dakota Koeleria macrantha, Redfieldia flexuosa, and Hesperostipa spartea (= Stipa spartea) are present at low abundance, and Carex inops ssp. heliophila is not present (Burgess 1965, Nelson et al. 1981). The lower herbaceous stratum is dominated by Carex spp., especially Carex inops ssp. heliophila. Other species that may be present are Artemisia frigida, Carex filifolia, Carex duriuscula (= Carex eleocharis), Dalea villosa (= Petalostemon villosus), and Yucca glauca.

Dynamics: Blowouts may occur in this community type, leading to bare soils or subsoils. Blowouts may be caused by severe droughts and windstorms, and may occur in conjunction with grazing pressures that reduce the ability of the vegetation cover to stabilize the sand. This type may be an early successional stage on these blowouts where vegetation cover and diversity are low. It may develop into Calamovilfa longifolia - Andropogon hallii Herbaceous Vegetation (CEGL001469) (Burgess 1965).

GRank \& Reasons: G3 (96-02-01). This type has a very restricted distribution both geographically, and in terms of site characteristics. Stands are only known from southeastern Montana and southeastern North Dakota, where they are typically less than a hectare in size. A recent rapid ecological assessment of the Northern Great Plains did not turn up any sites for this type, substantiating its restricted nature (Martin et al. 1998). Threats are not known.

Comments: This association occurs only in limited places. Rangewide review is still needed, e.g., distinctions between it and Andropogon hallii - Calamovilfa longifolia Herbaceous Vegetation (CEGL001467) are not entirely clear. Andropogon hallii occurs in Manitoba, but stands are placed in the Andropogon hallii - Calamovilfa longifolia Herbaceous Vegetation (CEGL001467) [see Looman 1980]. Stands in southeastern North Dakota may contain more tallgrass prairie associates, such as Andropogon gerardii, Symphyotrichum ericoides (=Aster 
ericoides), Lithospermum canescens, Solidago nemoralis, and Sporobolus heterolepis, than those in Montana.

The name of this association should probably be changed to Calamovilfa longifolia - Carex inops ssp. heliophila Carex filifolia Herbaceous Vegetation. Carex filifolia occurs on a wider variety of substrates than does Carex inops ssp. heliophila, which is more restricted to lighter sands. Steve Cooper (pers. comm. 1998) also notes that Carex filifolia occurs farther north and west in Montana than does Carex inops ssp. heliophila. In Montana, Carex inops ssp. heliophila also occurs on shales that have been weathered to sand particles. In North Dakota, this type is restricted to the western part of the state.

\section{ELEMENT DISTRIBUTION}

Range: This sand bluestem prairie community type is found in restricted areas of the northern Great Plains of the United States, including southeastern Montana and southeastern North Dakota.

States/Provinces: MT:S3, ND:S?

\section{ELEMENT SOURCES}

Authors: J. Drake, WCS Confidence: 1 Identifier: CEGL001466

References: Bourgeron and Engelking 1994, Burgess 1965, Culwell and Scow 1982, Driscoll et al. 1984, Heidel 1984a, Looman 1980, MTNHP 1988, Nelson et al. 1981

\section{V.A.5.N.A.11. CALAMOVILFA LONGIFOLIA HERBACEOUS ALLIANCE}

\section{CALAMOVILFA LONGIFOLIA - CAREX INOPS SSP. HELIOPHILA HeRBACEOUS VEgETATION}

Prairie Sandreed - Sun Sedge Herbaceous Vegetation

\section{ELEMENT CONCEPT}

Summary: This prairie sandreed grassland is found in the northwestern Great Plains of the United States and Canada. Stands typically occur on gentle slopes but can also be found on flat land or moderate to steep slopes. Soils are thin sands, sandy loams, and loamy sands, in places derived from sandstone. Moisture levels may be high deeper in the soil profile. Most stands of this community are not very large. The vegetation is dominated by graminoids, with two strata, one of mid to tall grasses, the other of dense short sedges. Shrubs are uncommon. In the taller grass layer, the most abundant species is Calamovilfa longifolia. Other species found in this layer include Koeleria macrantha, Schizachyrium scoparium, and Hesperostipa comata (= Stipa comata). Pascopyrum smithii may be present on some stands with finer soil textures. The short graminoid layer is composed chiefly of Carex filifolia and Carex inops ssp. heliophila, which may have high cover values. Other upland Carices, such as Carex duriuscula, as well as Bouteloua gracilis and Muhlenbergia pungens, may also be present. Forb species diversity is moderate but they do not contribute greatly to the cover. The forbs that are typical of this community include Artemisia dracunculus, Artemisia frigida, Artemisia ludoviciana, Chenopodium album, Chenopodium leptophyllum, Lathyrus spp., Liatris punctata, Lygodesmia juncea, Phlox hoodii, and Psoralidium lanceolatum.

Environment: Stands are found on gently rolling uplands with little to moderate slopes (typically between 0 and $20 \%$, but occasionally as high as 39\%) (Hirsch 1985, Hansen and Hoffman 1988). The soils are sand, sandy loam, or loamy sand and there is rarely substantial soil horizon development (Hanson and Whitman 1938). The parent material is sandstone (USFS 1992). Moisture levels may be high deep in the profile.

In Powder River County, this plant association is found within the Sandy Ecological Sites of the 10-14 and 15-19 inch precipitation zones.

Vegetation: The vegetation structure is somewhat open, with cover averaging $65 \%$ in parts of its range (USFS 1992). The vegetation is dominated by graminoids, with two strata, one of mid to tall grasses, the other of dense short sedges. In the taller grass layer, the most abundant species is Calamovilfa longifolia. Other species found in this layer include Koeleria macrantha, Schizachyrium scoparium, and Hesperostipa comata (= Stipa comata). Pascopyrum smithii may be present on some stands with finer soil textures. The short-graminoid layer is composed chiefly of Carex filifolia and Carex inops ssp. heliophila, which may have high cover values. Other upland Carices, such as Carex duriuscula (= Carex eleocharis), as well as Bouteloua gracilis and Muhlenbergia 
pungens, may also be present. Forb species diversity is moderate, but they do not contribute greatly to the cover (Hanson and Whitman 1938, USFS 1992). The forbs that are typical of this community include Artemisia dracunculus, Artemisia frigida (considered a shrub by some authors), Artemisia ludoviciana, Chenopodium album, Chenopodium leptophyllum, Lathyrus spp., Liatris punctata, Lygodesmia juncea, Phlox hoodii, and Psoralidium lanceolatum. Shrubs are uncommon. When shrubs are present they are short shrubs such as Yucca glauca, Rosa spp., and Artemisia frigida (considered a forb by some authors).

GRank \& Reasons: G3 (96-02-01). No occurrences have been documented, but the community is reported in 3 ecoregional subsections in Wyoming, Montana, North Dakota, South Dakota, and Saskatchewan. It is a very uncommon community in Badlands National Park, South Dakota.

Comments: The name of this association should probably be changed to Calamovilfa longifolia - Carex inops ssp. heliophila - Carex filifolia Herbaceous Vegetation. Carex filifolia occurs on a wider variety of substrates than does Carex inops ssp. heliophila, which is more restricted to lighter sands. Steve Cooper (pers. comm. 1998) also notes that Carex filifolia occurs farther north and west in Montana than does Carex inops ssp. heliophila. In Montana, Carex inops ssp. heliophila also occurs on shales that have been weathered to sand particles. In North Dakota, this type is restricted to the western part of the state.

\section{ELEMENT DISTRIBUTION}

Range: This prairie sandreed grassland is found in the northwestern Great Plains of the United States and Canada, ranging from the western Dakotas to Montana and Saskatchewan.

States/Provinces: MT:S3?, ND:SU, SD:S?, SK:S?

ELEMENT SOURCES

Authors: K. Hirsch, mod. J. Drake and D. Faber-Langendoen, WCS; mod. B. L. Heidel, MTNHP Confidence: 2 Identifier: CEGL001471

References: Bourgeron and Engelking 1994, Driscoll et al. 1984, Hansen 1985, Hansen and Hoffman 1988, Hansen et al. 1984, Hanson and Whitman 1938, Hirsch 1985, USFS 1992

\section{CALAMOVILFA LONGIFOLIA - HeSPERostipa COMATA HERBACEOUS Vegetation}

Prairie Sandreed - Needle-and-Thread Herbaceous Vegetation

\section{ELEMENT CONCEPT}

Summary: This prairie sandreed grassland community type occurs in the central and northern Great Plains region of the United States. Stands occur on stabilized sand dunes, as well as in interdunal valleys, colluvial sands, and, less commonly, silty terraces of intermittent streams. Soils are medium to fine sands formed either from eolian or colluvial processes. The vegetation has an open canopy, dominated by mid to tall grasses. Calamovilfa longifolia and Hesperostipa comata (= Stipa comata) are the most conspicuous and dominant grasses. Other common grasses include Bouteloua gracilis, Koeleria macrantha, Achnatherum hymenoides (= Oryzopsis hymenoides), Sporobolus cryptandrus. The type may grade into stands dominated by Pascopyrum smithii and Nassella viridula (= Stipa viridula) at the base of slopes. Andropogon hallii or Hesperostipa spartea (= Stipa spartea) may also be present. Sedges are rare, but could include Carex inops ssp. heliophila. Forb diversity ranges from low to moderate, depending on the site. Dry valley sand prairies may be particularly forb-rich. Silty terraces of intermittent streams may contain Artemisia frigida, Artemisia ludoviciana, Gutierrezia sarothrae, Psoralidium tenuiflorum, and Yucca glauca. Shrubs are scattered and infrequent to absent, with Rhus trilobata the most common species. These areas are highly susceptible to invasion by exotic brome grasses (Bromus japonicus, Bromus squarrosus, Bromus tectorum) and may be quite weedy.

Environment: Stands occur on stabilized sand dunes, as well as in interdunal valleys or draws, colluvial sands, and, less commonly, silty terraces of intermittent streams. Soils are medium to fine sands formed either from eolian or colluvial processes. For example, in Nebraska stands occur below sandstone outcrops and escarpments. More rarely, stands occur on floodplain terraces of intermittent streams, where soils are moderately deep, poorly drained, silty loams and loams (Heerwagen 1958, USDI 1979, Barnes et al. 1984, Steinauer and Rolfsmeier 2000). 
In Powder River County, this plant association is found in the Sandy Ecological Sites of the 10-14 inch precipitation zone.

Vegetation: The vegetation has an open canopy, dominated by mid to tall grasses. Calamovilfa longifolia is the most conspicuous grass. Other common grasses include Bouteloua gracilis, Bouteloua gracilis, Koeleria macrantha, Achnatherum hymenoides (= Oryzopsis hymenoides), Sporobolus cryptandrus, and Hesperostipa comata (= Stipa comata). Pascopyrum smithii (= Agropyron smithii) and Nassella viridula (= Stipa viridula) may occur on more level sites at the base of slopes (Barnes et al. 1984, Steinauer and Rolfsmeier 2000). Andropogon hallii may also be present. Sedges are rare but could include Carex inops ssp. heliophila. Forb diversity ranges from low to moderate, depending on the site. Dry valley sand prairies may be particularly forb-rich. Silty terraces of intermittent streams may contain Artemisia frigida, Artemisia ludoviciana, Gutierrezia sarothrae, Psoralidium tenuiflorum, and Yucca glauca (Steinauer and Rolfsmeier 2000). Shrubs are scattered and infrequent to absent, with Rhus trilobata the most common species. These areas are highly susceptible to invasion by exotic brome grasses (Bromus japonicus, Bromus squarrosus, Bromus tectorum) and may be quite weedy (Heerwagen 1958, USDI 1979, Steinauer and Rolfsmeier 2000).

Dynamics: Blowouts caused by drought and wind may occur in this type. The type probably represents a later successional stage. Earlier stages may be dominated by Andropogon hallii (e.g., Andropogon hallii - Calamovilfa longifolia Herbaceous Vegetation (CEGL001467)). Heavy grazing may increase the likelihood of blowouts.

GRank \& Reasons: G3 (96-02-01). The community is reported in 2 ecoregional sections in Wyoming, Colorado, and Nebraska. It is restricted primarily to stabilized sand dunes, as well as in interdunal valleys or draws, colluvial sands, and intermittent streams, but it has a moderately wide distribution in the central to northern Great Plains. Stands are typically less than a few hectares in size, but larger stands are found in interdunal valleys in Nebraska, some reaching 100 acres or more (G. Steinauer pers. comm. 1999). In Nebraska, this community can be heavily grazed and subsequently invaded by exotic species (Steinauer and Rolfsmeier 2000).

Comments: This type may perhaps be differentiated from other types, such as Calamovilfa longifolia - Carex inops ssp. heliophila Herbaceous Vegetation (CEGL001471), by the absence or low abundance of Carex filifolia and Carex inops ssp. heliophila, though why those species are not abundant in this type is not clear. Further floristic comparisons need to be made to help make the distinction clear between that type and this type. Some floristic variability is to be expected in this type, based on successional patterns following dune blowouts. Steve Kettler (pers. comm. 1998) says they don't have this type in Colorado. It sounds like a version of a locally described Andropogon hallii - Hesperostipa comata type, of which Colorado is also not very confident. Kettler suspects that a lot of the variation in grass dominance is from different management (grazing) over the years. The silty terrace stands are reported from the White River drainage in northwestern Nebraska and Badlands National Park, South Dakota (Von Loh et al. 1999, Steinauer and Rolfsmeier 2000).

\section{ELEMENT DISTRIBUTION}

Range: This prairie sandreed grassland community type occurs in the central and northern Great Plains region of the United States, ranging from Colorado and Nebraska, north to Wyoming and South Dakota.

This type has been documented in Powder River County, Montana.

States/Provinces: AB?, CO?, MT:S3, NE:S?, SD:S?, WY:S3

\section{ELEMENT SOURCES}

Authors: G. Steinauer and S. Rolfsmeier, mod. D. Faber-Langendoen, WCS; mod. B. L. Heidel, MTNHP Confidence: 2 Identifier: CEGL001473

References: BLM 1979b, Barnes et al. 1984, Bourgeron and Engelking 1994, CDM Consultants n.d., Driscoll et al. 1984, Heerwagen 1958, Johnston 1987, Mine Reclamation Consultants 1977, Steinauer and Rolfsmeier 2000, Von Loh et al. 1999 


\title{
V.A.5.N.c. Medium-tall sod temperate or subpolar grassland V.A.5.N.C.29. HESPEROSTIPA COMATA - BOUTELOUA GRACILIS HERBACEOUS ALLIANCE
}

\author{
HESPEROSTIPA COMATA - BOUTELOUA GRACILIS - CAREX FILIFOLIA HERBACEOUS VEGETATION
}

Needle-and-Thread - Blue Grama - Threadleaf Sedge Herbaceous Vegetation

\section{ELEMENT CONCEPT}

Summary: This needlegrass - grama grass prairie community is common in the northern and central Great Plains of the United States. Stands occur on flat to rolling topography with deep $(40-100 \mathrm{~cm})$, sandy loam to loam, coarser-textured soils. They are typically associated with uplands, though they may also occur lower in the landscape, such as coulee and draw bottoms, if soils are sufficiently coarse (usually sandstone-derived). The type is found at elevations ranging from $600-1700 \mathrm{~m}$ (2000-5500 feet); average annual precipitation associated with these elevation param ranges from slightly less than $25 \mathrm{~cm}$ to over $50 \mathrm{~cm}(10-20$ inches). The vegetation is dominated by moderate to moderately dense medium-tall grasses. Hesperostipa comata (= Stipa comata) is the tallest of the dominant species, sending seed heads to a maximum height of approximately $1 \mathrm{~m}$. The rhizomatous graminoids Bouteloua gracilis and Carex filifolia, the other two dominant/codominant species, do not usually exceed $0.5 \mathrm{~m}$. Calamovilfa longifolia is often found with high cover values on sandier soils, and Koeleria macrantha cover increases on degraded sites. There are regionalized expressions of variability with Carex inops ssp. heliophila surpassing Carex filifolia in Colorado and Calamagrostis montanensis being at least as important as the diagnostic species in north-central Montana. Pascopyrum smithii is consistently present. For woody species, subshrub forms (Artemisia frigida, Gutierrezia sarothrae, Rosa arkansana) have the highest cover and constancy, but their total cover does not sum to more than 5\%, except on overgrazed sites. Cover values for forbs are low (the exception being Selaginella densa). Geographic setting influences forb composition to some degree, with Sphaeralcea coccinea, Phlox hoodii, Heterotheca villosa, Gaura coccinea, and Liatris punctata common in the northern areas, and Lygodesmia juncea, Opuntia polyacantha, Artemisia dracunculus, and Ratibida columnifera seeming to increase to the eastern and southern areas.

Environment: Stands occur on flat to rolling topography with deep $(40-100 \mathrm{~cm})$ sandy loam to loam soils. They are typically associated with uplands, though they may also occur lower in the landscape, such as coulee and draw bottoms, if soils are sufficiently coarse (usually sandstone derived). Even though it is a major association in the Northern Plains, it does not occur in areas dominated exclusively by shale and mudstone parent materials, from which heavy soils are derived. This type is found at elevations ranging from 600 to $1700 \mathrm{~m}$ (2000-5500 feet); average annual precipitation associated with these elevation parameters ranges from slightly less than $25 \mathrm{~cm}$ to over $50 \mathrm{~cm}$ (10 to 20 inches).

Vegetation: The vegetation is dominated by moderately dense graminoids that are usually between 0.5 and $1 \mathrm{~m}$ tall. For example, on 19 stands in west-central Montana the cover by the different strata was as follows: shrubs $6 \%$, graminoids $67 \%$, forbs $11 \%$, bryophytes $14 \%$, litter $55 \%$, rock $4 \%$, bare soil $9 \%$ (Mueggler and Stewart 1978 ). Thilenius et al. (1995) found that the average cover on 14 stands in eastern Wyoming was $42 \%$. Hesperostipa comata (= Stipa comata) is the tallest of the dominant species, sending seed heads to a maximum height of approximately $1 \mathrm{~m}$. The rhizomatous graminoids Bouteloua gracilis and Carex filifolia, the other two dominant/ codominant species, do not usually exceed $0.5 \mathrm{~m}$. Calamovilfa longifolia is often found with high cover values on sandier soils and Koeleria macrantha cover increases on degraded sites. There are regionalized expressions of variability with Carex inops ssp. heliophila surpassing Carex filifolia in Colorado and Calamagrostis montanensis being at least as important as the diagnostic species in north-central Montana. Pascopyrum smithii is consistently present. For woody species, subshrub forms (Artemisia frigida, Gutierrezia sarothrae, Rosa arkansana) have the highest cover and constancy but their total cover does exceed more than 5\%, except on overgrazed sites. Cover values for forbs are low throughout the range of the type (the exception being Selaginella densa). Geographic setting does influence forb composition to some degree. Sphaeralcea coccinea, Phlox hoodii, Heterotheca villosa, Gaura coccinea, and Liatris punctata, have high constancy values in northern areas, whereas in the eastern and southern portions of the range Lygodesmia juncea, Opuntia polyacantha, Artemisia dracunculus and Ratibida columnifera seems to be more constant. 
Dynamics: Vast (singly and in the aggregate) prairie dog (Cynomys ludovicianus) "towns" once developed on the favorable substrates of this type and exploited its vegetation. Prairie dog populations have undergone a precipitous decline since settlement, so much of this type could be in various states of secondary succession, returning from a somewhat denuded state and altered composition created by the prairie dogs (and attendant bison that found nutritious forage here). Fire, both aboriginal- and lightening-caused, was a regular part of this landscape. Firereturn intervals have been considerably lengthened since settlement by European-Americans. This association and Pascopyrum smithii - Bouteloua gracilis - Carex filifolia Herbaceous Vegetation (CEGL001579) could be considered the most common plant associations in the Northern Great Plains (Martin et al. 1998). These two associations, cited by many authors as the climatic climax communities for this region, are manifested by matrix or large patch occurrences frequently found dominating whole landscapes. The Hesperostipa comata (= Stipa comata) defined community is more associated with uplands and the Pascopyrum smithii defined type characterizes sites with higher moisture status, generally occurring at lower positions in the landscape.

GRank \& Reasons: G5 (99-02-25). This is an exceedingly common type, manifesting any number of permutations, some of which are related to disturbance and some of which appear to be related to the expected geographic distinctions in such a broadly distributed type. The only reason to consider it a G4 is that it has received, and continues to receive, significant grazing pressure which, combined with the surge in alien weed populations, pose a significant threat to its quality.

Comments: Carex filifolia is lacking or highly reduced in importance southward. Southern stands were once classified separately (CEGL001699), and further review of their characteristics compared to more northern stands is needed. Weaver and Albertson (1956) also remark on the fact that low sedges are present as far south as Texas but are important only north of Colorado. However, a phase of the Hesperostipa comata - Bouteloua gracilis type of Mueggler and Stewart (1980) in western Montana is apparently quite similar to communities of the southern and southeastern portions or the Northern Great Plains, and both lack Carex filifolia. There are a welter of named community types, mostly seral representations of grazing or fire impacts, that vary by having one or another of the defining species (or even other graminoids, e.g., Carex inops ssp. heliophila) dominant. This assemblage of types is also defined by having relatively low cover of both Pascopyrum smithii and Elymus lanceolatus (= Agropyron dasystachyum). To accommodate these permutations within the concept of the type (as lesser-ranked occurrences) or to recognize them as independent vegetation types recognized by existing vegetation composition is one question. Another is, what cover value or degree of dominance of Pascopyrum smithii or Elymus lanceolatus will serve to establish the distinction between Pascopyrum smithii - Hesperostipa comata - Carex filifolia (and allied Pascopyrum smithii-"dominated" communities) from the community under consideration.

\section{ELEMENT DisTRIBUTION}

Range: This needlegrass - grama grass prairie community is common in the northern and central Great Plains of the United States and Canada, ranging from Manitoba west to Alberta, south to Kansas and possibly Colorado.

States/Provinces: AB:S?, CO?, KS:S?, MB:S3, MT:S?, ND:S3?, NE:S?, SD:S?, SK:S?, WY:S3

\section{ELEMENT SOURCES}

Authors: J. Drake, MCS; mod. B. L. Heidel, MTNHP Confidence: 1 Identifier: CEGL002037

References: Hansen et al. 1984, Hanson and Whitman 1938, Hubbard 1950, Johnston 1987, Looman 1980, Mueggler and Stewart 1980, Steinauer and Rolfsmeier 2000, Thilenius et al. 1995, Tolstead 1941, Tolstead 1942, Weaver and Albertson 1956

HeSPEROSTIPA COMATA - CAREX FILIFOLIA HERBACEOUS VEGETATION

Needle-and-Thread - Threadleaf Sedge Herbaceous Vegetation

Environment:

ELEMENT CONCEPT

In Powder River County, MT this plant association occurs on sandy, nearly-level uplands scattered along the Powder River and on top of isolated, sandstone-capped buttes and ridges.

\section{Vegetation:}

GRank \& Reasons: G4 (96-02-01). 
Comments: In Montana this plant association appears to correspond with a subset of environmental conditions for the Hesperostipa comata - Bouteloua gracilis - Carex filifolia plant association.

\section{ELEMENT DisTRIBUTION}

Range: In Montana, this plant association is reported from the Sioux District of Custer National Forest as well as national grasslands in South Dakota (Hansen and Hoffman 1988).

States/Provinces: MT:S4

ELEMENT SOURCES

Authors: WCS; mod. B. L. Heidel, MTNHP Confidence: 2 Identifier: CEGL001700

References: Bourgeron and Engelking 1994, Driscoll et al. 1984, Hansen 1985

\section{V.A.5.N.C.27. PASCOPYRUM SMITHII HERBACEOUS ALLIANCE}

PASCOPYRUM SMITHII - BOUTELOUA GRACILIS - CAREX FILIFOLIA HERBACEOUS VEGETATION

Western Wheatgrass - Blue Grama - Threadleaf Sedge Herbaceous Vegetation

\section{ELEMENT CONCEPT}

Summary: This western wheatgrass prairie community occurs throughout much of the northwestern Great Plains of the United States and Canada, on flat or gently sloping terrain. Many stands are on floodplains or gentle valley slopes. Some are on uplands. The soils are clay loam, silt loam, or loam and usually deep and fertile. This community is dominated by medium and short graminoids. The midgrass stratum is dominated by Pascopyrum smithii or Elymus lanceolatus. Common associates include Koeleria macrantha, Hesperostipa comata (= Stipa comata), and Nassella viridula. Hesperostipa comata is more common on the upper slopes and drier upland sites with sandier soils, whereas Nassella viridula is more common on the lower slopes and floodplains with finertextured soils. The most common short graminoid is Bouteloua gracilis. Other common graminoids include Carex filifolia, Carex inops ssp. heliophila, Carex duriuscula (= Carex eleocharis), and Carex pensylvanica. Forbs do not contribute much of the canopy cover but they are scattered throughout this community. Typical forbs are Tragopogon dubius, Gaura coccinea, Hedeoma hispida, Phlox hoodii and Sphaeralcea coccinea.

In Montana, this association occurs as a prevalent plant association across eastern plains landscapes and at all smaller scales on fine-textured soils. It has Pascopyrum smithii composing a significant portion of the canopy cover, representing mid-height stature and rhizomatous growth form, unless suppressed under drought cycles. Short stature graminoids (grasses and sedges) compose equal or greater cover than the canopy of mid-height grasses.

Environment: This community is found on flat or gently sloping terrain. Many stands are on floodplains or gentle valley slopes, others are on uplands. Surface layers of soils are usually clay loams, although stands of this type may also be found on loams, silt loams, silty clays and clays (Hanson and Whitman 1938, Hansen and Hoffman 1988). In Alberta and Saskatchewan this association grows on solonetzic soils (with an eluvial horizon above a dense clay horizon high in sodium salts) developed on thin glacial till over Cretaceous shale (Coupland 1961). This community does not appear to be found in mountain valleys (Hanson and Dahl 1956, Jones 1992).

In Montana, this community occurs on deep-soil settings of the plains on loams, silt loams, and clay loams, with or without impeded drainage. It spans the full range of topographic positions in its current vegetation definition, while sorting by topographic position and permeability depending on species dominance phase. This association and the Hesperostipa comata - Bouteloua gracilis - Carex filifolia Association (CEGL002037) could be considered the most common plant associations in the Northern Great Plains (Martin et al. 1998). These two associations, cited by many authors as the climatic climax communities for this region, are manifested by matrix or large patch occurrences frequently found dominating whole landscapes. The Hesperostipa comata defined community is more associated with uplands and the Pascopyrum smithii defined type characterizes sites with higher moisture status, generally occurring at lower positions in the landscape. 
In Powder River County, the association occurs on gentle slopes ranging from $0-35 \%$ and it is characteristic of the widespread Silty Ecological Site of the 10-14 inch precipitation zone. It is prevalent on gentler slopes within the Elso-Midway-Thurlow and the Elso-Remmit-Ocean Lake soil associations derived from calcareous shales. It also occurs on Silty Ecological Sites on well-drained deep-loam soils of the Elso - Ocean Lake association to the north. It is occasional on upland and bench positions with suitable substrate in the Ringling-Cabba-Midway association to the west, a Clayey Ecological Site of the 15-19 inch precipitation zone.

Vegetation: This community is dominated by medium and short graminoids. Total vegetation cover is usually high (Hanson and Dahl 1956, Hansen et al. 1984). Pascopyrum smithii or Elymus lanceolatus or both (the two species are similar both morphologically and ecologically) and Bouteloua gracilis usually contribute the most cover; however, Bouteloua gracilis cover may vary from codominant to locally absent. Carex filifolia, Carex duriuscula (= Carex eleocharis), and Carex pensylvanica are often secondary species, but they also vary from moderate cover to locally absent. Hesperostipa comata (= Stipa comata) usually is present as a secondary species, but it often codominates on sandy loam soils. In Alberta and Saskatchewan, Hesperostipa curtiseta (= Stipa spartea var. curtiseta) may be as common as Hesperostipa comata. Koeleria macrantha is present in most stands and may contribute substantial cover. The forbs most likely to be found in this association are Phlox hoodii, Sphaeralcea coccinea, Polygonum ramosissimum, Plantago patagonica, Opuntia polyacantha, Artemisia frigida, Antennaria microphylla, and Hedeoma hispida. In southeastern Montana, western North Dakota, and northeastern Wyoming, stands of this association often contain Artemisia tridentata ssp. wyomingensis. Exotic brome grasses, especially Bromus commutatus and Bromus tectorum, are present in many stands of this association and they commonly contribute substantial cover (Hanson and Dahl 1956, Coupland 1961, Hansen et al. 1984, Hansen and Hoffman 1988).

In Montana, this association occurs as a prevalent plant association across eastern plains landscapes and at all smaller scales on fine-textured soils. It has Pascopyrum smithii composing a significant portion of the canopy cover, representing mid-height stature and rhizomatous growth form, unless suppressed under drought cycles. Short stature graminoids (grasses and sedges) compose equal or greater cover than the canopy of mid-height grasses.

We note that in Powder River County, all combinations of species as co-dominants have been documented. Buchloe dactyloides is also a recurring co-dominant to add to the plant association description. In places codominated by Pascopyrum smithii and Buchloe dactyloides, the cover of grasses was high under good range conditions (greater than $70 \%$ ) and the cover of forbs was low, often including one or more of the following: Agoseris glauca, Hedeoma hispida, Lomatium foeniculaceum, Linum australe, Psoralea argophylla, and Sphaeralcea coccinea. Under degraded range conditions, the cover of annual bromes, Vulpia octoflora and Poa secunda increased, and the cover of Pascopyrum smithii decreased. Forb cover was significant only under degraded conditions, with such non-native or increaser species as Alyssum desertorum, Camelina sativa, Opuntia polyacantha and Plantago eriopoda. In the course of this study, we took ten plots and extensive field notes, with particular emphasis on documenting the vegetation co-dominated by Pascopyrum smithii and Buchloe dactyloides that was extensive on BLM lands.

Dynamics: In the past, fire likely occurred commonly in this type. Vast (singly and in the aggregate) prairie dog (Cynomys ludovicianus) "towns" once developed on the favorable substrates of this type and exploited its vegetation. Prairie dog populations have undergone a precipitous decline since settlement, so much of this type could be in various states of secondary succession, returning from a somewhat denuded state and altered composition created by the prairie dogs (and attendant bison that found nutritious forage here). Fire, both aboriginal- and lightening-caused, was a regular part of this landscape. Fire-return intervals have been considerably lengthened since settlement by European-Americans.

GRank \& Reasons: G4 (96-02-01). The G4 rank is based on the broad geographic range of this type, and its status as a common vegetation type within that range. Heavy grazing and lack of fire throughout its range may cause many stands to have a high proportion of exotics.

High-ranked species: Check for correlation with black-tailed prairie dog towns in the area. 
Comments: Almost any combination of Pascopyrum smithii, Bouteloua gracilis, Carex filifolia, and Hesperostipa comata (= Stipa comata) can be found in the northern and northwestern Great Plains, and the relative amounts of these species apparently depend at least in part on soil texture and grazing history. Moreover, drought or wet weather can cause the relative amounts of these species in one stand to change markedly in a few years (Ellison and Woolfolk 1937, Weaver and Albertson 1956). Consequently, differentiating between plant associations based solely on the relative amounts of these species is extremely difficult. This Pascopyrum smithii - Bouteloua gracilis - Carex filifolia association is found on soils in textural classes finer than loam in which Pascopyrum smithii and/or Elymus lanceolatus (which is similar morphologically and ecologically) contribute at least as much cover as does Hesperostipa comata. Bouteloua gracilis, Elymus lanceolatus and Carex filifolia may be patchily distributed, so areas of several acres should be examined to determine whether the vegetation belongs to this association. This association shares major graminoid species with Hesperostipa comata - Bouteloua gracilis Carex filifolia Herbaceous Vegetation (CEGL002037) but in the latter association, Hesperostipa comata contributes more cover than do Pascopyrum smithii or Elymus lanceolatus, and the latter association grows on soils of loam or coarser texture.

Recognition of this plant association in Montana is complicated by four factors. 1) There is a basic question on delimiting the Pascopyrum smithii Alliance as separate from the Hesperostipa comata - Bouteloua gracilis Alliance and possibly others. The classification work to date has amassed information from the literature that includes different standards of measure (basal cover vs. canopy cover) as well as different climate cycles. Classification within the "wheatgrass-needlegrass" domain of Kuchler (1964) may result in different dominance types depending on whether defined by canopy dominance or basal cominance. 2) The interchangeability and ecological equilivence of Pascopyrum smithii and Elymus lanceolatus and the similar needlegrass species-pair has not been analyzed in detail. They sort by latitude in their distribution and their tendency to have different environmental modes where they occur together warrants extended documentation. Note: Elymus lanceolatus is uncommon in Powder River County compared to Pascopyrum smithii. It is most common on overflow outwashes and panspots. 3) There are many different expressions of the plant association that have been well-documented. In one of its most widespread forms, Hesperostipa comata is associated with Pascopyrum smithii and Bouteloua gracilis. In the Ashland District of Custer National Forest, Pascopyrum smithii is associated with Carex filifolia (Hansen and Hoffman 1988). In broad, hot alluvial flats, there are reports of Pascopyrum smithii occurring repeatably with Bouteloua gracilis (Heidel et al. 2000). Given the current concept of this type, they all fit within the type, but not all of their environmental characteristics fit. 4) The codominance of Buchloe dactyloides with Pascopyrum smithii, as documented on BLM-administered lands in much of Powder River County, has not been well-documented in the northern Great Plains. Vegetation dominated by Pascopyrum smithii, Buchloe dactyloides and Bouteloua gracilis was briefly described in the South Dakota Badlands (Tolstead 1941), and mapped accordingly by Kuchler (1964). It is widely accepted that heavy grazing favors increased cover of Buchloe dacytloides, as demonstrated on clay range sites at the Fort Keogh Livestock and Range Experiment Station of the northern Great Plains (Reed and Peterson 1961), as well as in the central and southern Great Plains.

In Powder River County, the two species are ubiquitous on silty range sites. The cover values of Pascopyrum smithii typically ranged from $20-30 \%$, but in moisture-collecting settings and successional conditions, may exceed $50 \%$. The cover of Buchloe dactyloides were typically around $60 \%$. It superficially resembled blue grama (Bouteloua gracilis), from which it differs in vegetative reproduction by stolons, dioecious spikelets, and leaf surface characteristics. The latter was not present above a trace in plots with this association. The cover of individual native forb species was only a trace.

In Powder River County, we documented co-dominance of Pascopyrum smithii and Buchloe dactyloides as prevalent on eastern plains. Co-dominance of Pascopyrum smithii and Carex filifolia has been documented on ridge systems to the west (Hansen and Hoffman 1988) and we documented co-dominance of Pascopyrum smithii, Hesperostipa comata and Bouteloua gracilis with changes in substrate to the north.

\section{ELEMENT DisTRIBUTION}

Range: This western wheatgrass prairie community occurs throughout much of the northwestern Great Plains of the United States and Canada on flat or gently sloping terrain, ranging from Alberta and Saskatchewan in Canada south to Nebraska and possibly Colorado.

In Powder River County, there are extensive areas of fine-textured soils where this is the prevalent plains plant 
association.

States/Provinces: AB:S?, CO?, MT:S4, ND:S3?, NE:S3S4, SD:S4, SK:S?, WY?

\section{ELEMENT SOURCES}

Authors: H.C. Hanson and W. Whitman, mod. J. Drake and D. Faber-Langendoen, WCS; mod. B. L. Heidel, MTNHP Confidence: 2 Identifier: CEGL001579

References: Bourgeron and Engelking 1994, Driscoll et al. 1984, Ellison and Woolfolk 1937, Hansen 1985, Hansen and Hoffman 1988, Hansen et al. 1984, Hanson and Dahl 1956, Hanson and Whitman 1938, Johnston 1987, Jones 1992b, Kuchler 1964, Ode pers. comm., Steinauer and Rolfsmeier 2000, Weaver and Albertson 1956

\section{PASCOPYRUM SMITHII HERBACEOUS VEGETATION}

Western Wheatgrass Herbaceous Vegetation

\section{ELEMENT CONCEPT}

Summary: This midgrass prairie type is found in the northern and western Great Plains, Rocky Mountains, and the interior western United States and possibly Canada. Stands occur on level to gently sloping terrain. They are found on alluvial fans, swales, river terraces, floodplains, valley floors and basins. The soils are clay, clay loam, and silt loam. Pascopyrum smithii strongly dominates the moderate to dense (40-100\% cover) mixedgrass herbaceous canopy that grows $0.5-1 \mathrm{~m}$ tall. Other graminoids that co-occur and may achieve local dominance are Koeleria macrantha, Eleocharis palustris, and Poa spp. Many other species common in midgrass prairies are also found in this community. These include Artemisia ludoviciana, Eriogonum spp., Bouteloua gracilis, Nassella viridula, and Hesperostipa comata (= Stipa comata). Shrubs and dwarf-shrubs are rare in this community, but occasional woody plants such as Artemisia tridentata, Symphoricarpos spp., Ericameria nauseosa, or Krascheninnikovia lanata may be present. Introduced species, such as Bromus tectorum, Bromus inermis, Poa pratensis, Melilotus spp. or Cirsium arvense, are common in some stands, especially where disturbed.

Environment: This grassland association is widespread in the northern and western Great Plains, Rocky Mountains, the intermountain western United States and possibly Canada. Elevation ranges from 600-3000. Stands occur on level to gently sloping terrain. They are found on alluvial fans, swales, river terraces, floodplains, valley bottoms and basins. The soils are deep (40-100 cm) and well-developed with clay, clay loam, and silt loam textures. Some stands occur on perched water tables.

Vegetation: This association is characterized by a moderate to dense (40-100\% cover) mixedgrass herbaceous canopy that grows $0.5-1 \mathrm{~m}$ tall and is strongly dominated by Pascopyrum smithii. Other graminoids that co-occur and may achieve local dominance are Koeleria macrantha, Eleocharis palustris, and Poa spp. Many other species common in midgrass prairies are also found in this community. These include Artemisia frigida, Artemisia ludoviciana, Achillea sp., Carex spp., Eriogonum spp., Bouteloua gracilis, Nassella viridula, and Hesperostipa comata (= Stipa comata). Shrubs and dwarf-shrubs are rare in this community, but occasional woody plants such as Symphoricarpos spp., Ericameria nauseosa, or Krascheninnikovia lanata may be present. Introduced species, such as Bromus tectorum, Bromus inermis, Poa pratensis, Melilotus spp., Cirsium arvense, Taraxacum officinale, or Salsola kali, are common in some stands, especially where disturbed.

Dynamics: In semi-arid climates, this association is found in relatively mesic topographic positions such as swales, river terraces, floodplains and basins that may be temporarily or intermittently flooded or in some classes, the fine textured soil sometimes perches the water table (Hansen et al. 1995, Hansen and Hall 1997). In more mesic climates it is found in extensive upland areas.

GRank \& Reasons: G3G5Q (96-02-01).

Comments: This community is similar to several others that are dominated or codominated by Pascopyrum smithii. As currently defined, it represents a western Great Plains and foothills version of the western wheatgrass types in the central Great Plains. Further work needs to be done to refine the differences in composition and environmental characteristics. See recent descriptions by Thilenius et al. (1995) (Pascopyrum smithii sodgrass 
steppe, a more playa-like wheatgrass type) and by Steinauer and Rolfsmeier (2000). In Nebraska, Steinauer and Rolfsmeier (2000) suggest that their stands may resemble Pascopyrum smithii - Nassella viridula Herbaceous Vegetation (CEGL001583).

\section{ELEMENT DisTRIBUTION}

Range: This midgrass prairie type is found in the northern and western Great Plains, Rocky Mountains, intermountain western United States and possibly Canada, ranging from North Dakota and possibly Saskatchewan, south to Nebraska and Colorado, west to northern Arizona, Utah and Idaho.

States/Provinces: AZ:S?, CO:S1?, ID:S1Q, MT:S4, NE:S?, SD:S?, SK:S?, UT:S3S5, WY:S4Q

\section{ELEMENT SOURCES}

Authors: J.F. Drake, mod. K. Schulz, WCS Confidence: 3 Identifier: CEGL001577

References: Aldous and Shantz 1924, Baker 1983c, Baker 1984a, Baker and Kennedy 1985, Bourgeron and Engelking 1994, Bunin 1985, Christensen and Welsh 1963, Driscoll et al. 1984, Godfread 1994, Hall and Hansen 1997, Hansen et al. 1991, Hansen et al. 1995, Jones and Walford 1995, Marr and Buckner 1974, Ramaley 1916b, Ramaley 1919b, Ramaley 1942, Shanks 1977, Soil Conservation Service 1978, Steinauer and Rolfsmeier 2000, Thilenius et al. 1995, Von Loh 2000

\section{V.A.5.N.C.20. SCHIZACHYRIUM SCOPARIUM - BOUTELOUA CURTIPENDULA HERBACEOUS ALLIANCE}

SCHIZACHYRIUM SCOPARIUM - BOUTELOUA (CURTIPENDULA, GRACILIS) - CAREX FILIFOLIA HERBACEOUS VEGETATION

Little Bluestem - (Sideoats Grama, Blue Grama) - Threadleaf Sedge Herbaceous Vegetation

\section{ELEMENT CONCEPT}

Summary: This little bluestem - mixedgrass prairie type is distributed throughout the northern Great Plains of the United States and Canada. Stands are usually found on moderate to steep slopes with variable aspects. The soils are typically shallow and occur over sandstone or limestone. The vegetation is predominantly composed of graminoid species less than $1 \mathrm{~m}$ tall with moderate to high cover. The dominant species is Schizachyrium scoparium with Bouteloua curtipendula, Bouteloua gracilis, and Carex filifolia as associates or codominants. Andropogon gerardii, Carex inops ssp. heliophila, Carex duriuscula, Koeleria macrantha, and Calamovilfa longifolia are often present. Calamovilfa longifolia may be abundant on sandier soils. Muhlenbergia cuspidata, Hesperostipa comata (= Stipa comata), Pascopyrum smithii, and Nassella viridula may also be present. Forbs do not contribute greatly to the canopy, but many species may be found in this community. Among the forbs that may be found are Echinacea angustifolia, Symphyotrichum oblongifolium (= Aster oblongifolius), Gaura coccinea, Lygodesmia juncea, Helianthus pauciflorus ssp. pauciflorus, Rosa arkansana, Liatris punctata, Pediomelum argophyllum, Symphyotrichum ericoides (= Aster ericoides), Dalea purpurea, and Campanula rotundifolia.

Environment: This community is usually found on gentle to steep slopes with variable aspects (Hansen et al. 1984, Johnston 1987, Hansen and Hoffman 1988). The soil may be loamy sand, sandy loam, loam, or clay loam. There may be a substantial component of gravel. Hansen et al. (1984) found 7-36\% gravel by weight in 16 stands in western North Dakota. The soils are typically shallow and occur over sandstone or limestone (Johnston 1987, Thilenius et al. 1995).

Vegetation: This community is predominantly composed of graminoid species less than $1 \mathrm{~m}$ tall. Pinus ponderosa may occasionally be present. The vegetation cover is moderate to high. Thilenius et al. (1995) found that vegetation cover was $44 \%$ in Wyoming, and Hansen and Hoffman (1988) found $75 \%$ cover in North Dakota. The dominant species is Schizachyrium scoparium, with Bouteloua curtipendula, Bouteloua gracilis, and Carex filifolia as associates or codominants. Andropogon gerardii, Carex inops ssp. heliophila, Carex duriuscula (= Carex eleocharis), Koeleria macrantha and Calamovilfa longifolia are often present. Calamovilfa longifolia may be abundant on sandier soils. Muhlenbergia cuspidata, Hesperostipa comata (= Stipa comata), Pascopyrum smithii, and Nassella viridula may also be present. Pseudoroegneria spicata may be found in the western portions of this community (Jones 1992). In Manitoba, the graminoids Festuca ovina and Elymus trachycaulus and the 
lichen Selaginella densa are more abundant (Greenall 1995). Forbs do not contribute greatly to the canopy, but many species may be found in this community (Hanson and Whitman 1938). Among the forbs that may be found are Echinacea angustifolia, Symphyotrichum oblongifolium (= Aster oblongifolius), Symphyotrichum ericoides (= Aster ericoides), Gaura coccinea, Lygodesmia juncea, Helianthus pauciflorus ssp. pauciflorus, Rosa arkansana, Liatris punctata, Pediomelum argophyllum (= Psoralea argophylla), Dalea purpurea, Phlox hoodii, and Campanula rotundifolia. There are very few woody species; those that are present are usually short shrubs such as Artemisia frigida, Juniperus horizontalis, and Yucca glauca. Litter often accumulates and may cover more than $50 \%$ of the ground (Hirsch 1985).

Dynamics: Fire probably played a major role in this type, whereby periodic fires would increase graminoid production and deter tree growth.

GRank \& Reasons: G3G4 (99-09-09).

Comments: Contrast this association with Schizachyrium scoparium - Bouteloua curtipendula grasslands in New Mexico. Hansen et al. (1984) report that Bouteloua gracilis and Koeleria macrantha (= Koeleria cristata) may be prominent in Theodore Roosevelt National Park, North Dakota.

\section{ELEMENT DiSTRIBUTION}

Range: This little bluestem mixedgrass prairie type is distributed throughout the northern Great Plains of the United States and Canada, ranging from Manitoba and possibly Saskatchewan, south to South Dakota and Wyoming.

States/Provinces: MB:S?, MT:S?, ND:S3?, SD:S?, SK:S?, WY:S3

\section{ELEMENT SOURCES}

Authors: P.L. Hansen, G.R. Hoffman, and A.J. Bjugstad, mod. J. Drake and D. Faber-Langendoen, WCS; mod. B. L. Heidel, MTNHP Confidence: 2 Identifier: CEGL001681

References: Bourgeron and Engelking 1994, Butler and Goetz 1986, Driscoll et al. 1984, Greenall 1995, Hansen 1985, Hansen and Hoffman 1988, Hansen et al. 1984, Hanson and Whitman 1938, Hirsch 1985, Johnston 1987, Jones 1992b, MTNHP 1988, McAdams et al. 1998, Thilenius 1972, Thilenius et al. 1995

\section{V.A.5.N.C.35. SCHIZACHYRIUM SCOPARIUM HERBACEOUS ALLIANCE}

SCHIZACHYRIUM SCOPARIUM - CAREX INOPS SSP. HELIOPHILA HERBACEOUS VEGETATION

Little Bluestem - Sun Sedge Herbaceous Vegetation

Summary:

\section{ELEMENT CONCEPT}

Environment: In Powder River County, this plant association is found in Sandy Ecological Sites, 10-14 inch precipitation zone.

Vegetation:

Dynamics:

GRank \& Reasons: G3 (96-02-01).

Comments:

ELEMENT DisTRIBUTION

Range:

States/Provinces: MT:S3

Element Sources

Authors: WCS; mod. B. L. Heidel, MTNHP Confidence: 2 Identifier: CEGL001682

References: Bourgeron and Engelking 1994, Culwell and Scow 1982, Driscoll et al. 1984 


\section{V.A.5.N.d. Medium-tall bunch temperate or subpolar grassland V.A.5.N.D.8. FESTUCA IDAHOENSIS HERBACEOUS ALLIANCE}

\section{FESTUCA IDAHOENSIS - CAREX INOPS SSP. HELIOPHILA HERBACEOUS VEGETATION}

Idaho Fescue - Sun Sedge Herbaceous Vegetation

\section{ELEMENT CONCEPT}

Summary: Festuca idahoensis - Carex inops ssp. heliophila Herbaceous Vegetation is found in the northern Great Plains on upland plateaus and in open areas surrounded by ponderosa pine forest. It is found on moderate slopes (5-15\%) of all aspects at around $1200 \mathrm{~m}$ elevation. Soils tend to range from loam to sandy loam. Festuca idahoensis is clearly dominant, and Carex inops ssp. heliophila (= Carex heliophila) is constant and abundant. Also usually present are Koeleria macrantha (= Koeleria pyramidata), Artemisia ludoviciana, Symphyotrichum ericoides (= Aster ericoides), and Pascopyrum smithii (= Agropyron smithii). Hesperostipa comata (= Stipa comata) is often present but only as a minor component of the vegetation.

Environment: This herbaceous vegetation type is found on moderate slopes (5-15\%) of all aspects at around 1200 $\mathrm{m}$ elevation. Soils tend to range from loam to sandy loam.

Vegetation: Shrubs and forbs are present, but this type is clearly dominated by graminoids, with Festuca idahoensis being the most prominent species. There is often some exposed soil.

GRank \& Reasons: G3 (96-02-01).

Comments: This vegetation type was documented on an unglaciated landscape and may not occur on the glaciated portions of the Great Plains. Festuca idahoensis - Carex inops ssp. heliophila Herbaceous Vegetation (CEGL001610) is separated from Hesperostipa comata - Carex inops ssp. heliophila of Hansen and Hoffman (1988) by the predominance of Festuca idahoensis and by the lack of significant cover of Hesperostipa comata (= Stipa comata). The Festuca idahoensis - Carex inops ssp. heliophila type also has less forb coverage, less leaf litter and more exposed soil (ibid.). Several studies have documented Festuca idahoensis types that have Carex spp. as a dominant associate. Generally however, the species of Carex noted as predominant is different. Carex obtusata is listed as a main component for a number of types (Hansen and Hoffman 1988). Mueggler and Stewart (1980) note a Festuca idahoensis - Carex filifolia habitat type.

\section{ELEMENT DISTRIBUTION}

Range: This community is found in Montana.

States/Provinces: MT:S3

\section{ELEMENT SOURCES}

Authors: WCS Confidence: 1 Identifier: CEGL001610

References: Bourgeron and Engelking 1994, Driscoll et al. 1984, Hansen 1985, Hansen and Hoffman 1988, Mueggler and Stewart 1980

\section{V.A.5.N.D.22. PSEUDOROEGNERIA SPICATA HERBACEOUS ALLIANCE}

\section{PSEUdoroegNERIA SPICATA - BOUTELOUA CURTIPENDULA HERBACEOUS VEGETATION}

Bluebunch Wheatgrass - Sideoats Grama Herbaceous Vegetation

\section{ELEMENT CONCEPT}

Summary: This mixedgrass association ranges in size from small to large patches which are located on foothills and sideslopes along major drainages between the Tongue and Powder rivers of southeastern Montana. This type is considered a topo-edaphic climax by Hansen and Hoffman (1988) because it occurs on moderate to steep $(>45 \%)$ slopes the surfaces of which are strewn with large amounts of irregularly shaped, iron oxide porcelainite shale (scoria). The surface resulted from fires in contiguous coal beds (but the soils are conventional loams). The harsh sites of this type result in a unique depauperate community with the lowest total cover and graminoid cover of any southeastern Montana type inventoried by Hansen and Hoffman (1988). However, it still has greater cover 
and is more productive than those communities associated with bentonite deposits and acid shales.

Pseudoroegneria spicata is strongly dominant (canopy cover ranging from 40-60\%) with Bouteloua curtipendula exhibiting less than one-fourth this value. Pascopyrum smithii (= Agropyron smithii) and Schizachyrium scoparium are consistently present with cover less than $10 \%$. Forbs are a minor component with Lygodesmia juncea, Echinacea angustifolia and Pediomelum argophyllum (= Psoralea argophylla) having the highest fidelity to the type.

Environment: This type occurs as small to large patches located on foothills and sideslopes along major drainages between the Tongue and Powder rivers of southeastern Montana; known elevations range between 3100 and 3800 feet. This type is considered a topoedaphic climax by Hansen and Hoffman (1988) because it occurs on moderate to steep (>45\%) slopes, the surfaces of which are strewn with large amounts of irregularly shaped, iron oxide porcelainite shale (scoria) that has resulted from ancient fires in contiguous coal beds. The soils are conventional loams but shallow and excessively drained.

Vegetation: Pseudoroegneria spicata is strongly dominant (canopy cover ranging from 40-60\%) with Bouteloua curtipendula exhibiting less than one-fourth this cover value. Pascopyrum smithii (= Agropyron smithii) and Schizachyrium scoparium are consistently present with cover less than $10 \%$. Forbs are a minor component with Lygodesmia juncea, Echinacea angustifolia and Pediomelum argophyllum (= Psoralea argophylla) having the highest fidelity to the type. The shrubs (subshrubs) Rhus trilobata, Gutierrezia sarothrae and Artemisia frigida are consistently present with low coverage values (less than $5 \%$ ).

Dynamics: Given the low cover and patchiness of this type, fires probably burned in a mosaic fashion with reduced intensity. Pronghorn antelope use these sites for grazing and predator detection.

GRank \& Reasons: G3 (99-12-01). As currently understood, this type is restricted both geographically and with regard to site parameters. However, appropriate habitat in Wyoming overlaps the distribution of the characteristic species, so inventory may yield more occurrences. Threats to this type could potentially come from domestic stock, but sites are generally somewhat removed from water. These sites are generally not conducive to alien Bromus species, but their potential to support other weeds is unknown.

Comments: Pseudoroegneria spicata - Bouteloua curtipendula appears to be endemic to southeastern Montana, occurring between the Tongue and Powder rivers. Other portions of southeastern Montana and adjacent Wyoming would appear to have appropriate habitat (soils derived from scoria clinker) but lack populations of Bouteloua curtipendula or Pseudoroegneria spicata because they are at the extreme western and eastern extensions of their respective ranges and consequently sporadically distributed. There would seem to be some sites intermediate between Rhus trilobata / Pseudoroegneria spicata Shrub Herbaceous Vegetation (CEGL001120) and this type and for which it would be helpful to have an arbitrary cover cutoff value for Rhus trilobata for assigning stands to types. In the Rapid Ecological Assessment of the Northern Great Plains this type was recorded but once (Martin et al. 1998). Rhus trilobata / Pseudoroegneria spicata Shrub Herbaceous Vegetation (CEGL001120) differs from this community by having Rhus trilobata dominant or at least well represented. Pseudoroegneria spicata - Carex filifolia Herbaceous Vegetation (CEGL001665) differs from this association by lacking Bouteloua curtipendula and having Carex filifolia with at least 5\% cover, though it may not be the dominant graminoid. Pseudoroegneria spicata - Bouteloua gracilis Herbaceous Vegetation (CEGL001664) of western Montana occurs for the most part west of the distribution of Bouteloua curtipendula and where Bouteloua gracilis is the undergrowth dominant.

\section{ELEMENT DISTRIBUTION}

Range: This association has been recorded for only southeastern Montana, though appropriate habitat ostensibly occurs in northeastern Wyoming and westernmost North Dakota.

States/Provinces: MT:S3, ND:S?, WY?

\section{ELEMENT SOURCES}

Authors: S.V. Cooper, WCS; mod. B. L. Heidel, MTNHP Confidence: 2 Identifier: CEGL001663

References: Bourgeron and Engelking 1994, Driscoll et al. 1984, Hansen 1985, Hansen and Hoffman 1988 
PSEUDOROEGNERIA SPICATA - CAREX FILIFOLIA HERBACEOUS VEGETATION

Bluebunch Wheatgrass - Threadleaf Sedge Herbaceous Vegetation

\section{ELEMENT CONCEPT}

Summary: Stands of this association occur on level or gently sloping upland sites with loam or silt loam soils. This is an herbaceous vegetation type in which graminoids contribute most of the cover. A number of forbs may be present, but forbs and shrubs contribute little cover to the vegetation. Pseudoroegneria spicata dominates the vegetation, and Carex filifolia contributes substantial cover. Small amounts of Bouteloua gracilis may be present.

Environment: Stands of this association have been described from nearly level sites (some windswept) with loam and silt loam soils. Elevations range from about 4100 feet on the Great Plains to about 7000 feet on the west flank of the Bighorn Mountains.

Vegetation: Graminoids contribute most of the cover, and forbs are secondary; shrubs may be present as scattered individuals or clumps that contribute little cover to the vegetation. Pseudoroegneria spicata dominates the vegetation, and Carex filifolia contributes substantial cover. Hesperostipa comata (= Stipa comata), Koeleria macrantha, and Carex inops ssp. heliophila (= Carex heliophila) (in Great Plains stands) often are present in smaller amounts, but they may contribute as much cover as does Carex filifolia. Bouteloua gracilis is absent or present only in small amounts. Cheatgrass (Bromus japonicus, Bromus tectorum) is present in many stands and may contribute nearly as much cover as does Pseudoroegneria spicata. The vegetation may contain small amounts of numerous forbs. Shrubs are absent or present only as scattered individuals (especially Artemisia tridentata ssp. wyomingensis), but the subshrubs Artemisia frigida and Gutierrezia sarothrae usually are present in small amounts.

GRank \& Reasons: G4 (96-02-01)

Comments: This association seems to resemble very closely, in environment and vegetation, the more widespread Pseudoroegneria spicata - Bouteloua gracilis Herbaceous Vegetation (CEGL001664), except that this association contains little or no Bouteloua gracilis. The geographic ranges of the two associations overlap, and it is unclear whether good reasons exist to differentiate the two.

\section{ELEMENT DisTRIBUTION}

Range: This association has been described from two stands in southeastern Montana (Hansen and Hoffman 1988) and from two stands (Fisser 1964) and cursory information (Despain 1973a) in north-central Wyoming.

States/Provinces: MT:S4, WY:S?

\section{ELEMENT SOURCES}

Authors: WCS Confidence: 1 Identifier: CEGL001665

References: Bourgeron and Engelking 1994, Cotter-Ferguson Project n.d., Despain 1973a, Driscoll et al. 1984, Fisser 1964, Hansen 1985, Hansen and Hoffman 1988, Johnston 1987

PSEUdOROEGNERIA SPICATA - PASCOPYRUM SMITHII HERBACEOUS VEGETATION

Bluebunch Wheatgrass - Western Wheatgrass Herbaceous Vegetation

\section{ELEMENT CONCEPT}

Summary: This grassland association is found in the northern Great Plains and in the eastern foothills of the northern U.S. Rocky Mountains. Stands generally grow on slopes with shallow soils. Pseudoroegneria spicata dominates the vegetation, and rhizomatous wheatgrasses (Pascopyrum smithii or Elymus lanceolatus) are abundant. Forbs and shrubs contribute little cover.

Environment: Stands of this grassland association grow over a broad elevation range, from 2600 feet in Great Plains to 7500 feet in the foothills of the Rocky Mountains. They occur on slopes, from gentle alluvial fans to slopes as steep as $40 \%$, facing all aspects. Substrates are glacial deposits, alluvium, limestone, and calcareous sandstones. Soils usually are shallow, may contain a substantial volume of coarse fragments, and belong to sandy 
clay loam, loam, or clay loam textural classes. The sites often are exposed to strong, persistent winds.

Vegetation: Grasses contribute most of the cover and production. Pseudoroegneria spicata dominates (usually strongly). The rhizomatous wheatgrasses Pascopyrum smithii or Elymus lanceolatus (or both) are secondary species, but the rhizomatous wheatgrasses may codominate with Pseudoroegneria spicata. Hesperostipa comata (= Stipa comata), Koeleria macrantha, and Poa secunda usually are present in smaller amounts, but Hesperostipa comata often codominates in west-central Montana (Jorgensen 1979). Bouteloua gracilis is absent or is a minor species. Nassella viridula (= Stipa viridula) contributes substantial cover in some stands, especially in the Great Plains but also in some foothills stands (Mueggler and Stewart's (1980) Stipa viridula phase). Stands in the foothills often contain Poa cusickii, Leucopoa kingii, and Calamagrostis montanensis. In southeastern Montana (Hansen and Hoffman 1988) and northeastern Wyoming (Terwilliger et al. 1979a), Bouteloua curtipendula may also occur in the vegetation. Forbs contribute little cover or production, but a number of species may be present, including Ambrosia psilostachya (in Great Plains stands), Draba oligosperma, Erigeron compositus, Stenotus acaulis (= Haplopappus acaulis), Heterotheca villosa, Sphaeralcea coccinea, Phlox hoodii, Tragopogon dubius, and Vicia americana. The subshrubs Artemisia frigida and Gutierrezia sarothrae usually are present in small amounts. Shrubs generally are absent or are present only as scattered individuals, but Tweit and Houston (1980) note that Tetradymia canescens may be common and Chrysothamnus spp. may form a distinct shrub layer in disturbed stands.

GRank \& Reasons: G4 (96-02-01).

Comments: The inclusion of Hansen and Hoffman's (1988) stand number 25 from southeastern Montana extends the range of variability in vegetation found in this association. That stand contains Bouteloua curtipendula as an important species, and its inclusion in this association may be inappropriate. Similarly, it is unclear how much Bouteloua gracilis and Carex filifolia should be allowed in the vegetation for a stand to be placed into this association. In Pseudoroegneria spicata - Poa secunda Herbaceous Vegetation (CEGL001677), rhizomatous wheatgrasses are absent or contribute little cover.

\section{ELEMENT DisTRIBUTION}

Range: This association has been described from western and central Montana (Jorgensen 1979, Mueggler and Stewart 1980, Cooper et al. 1995), northeastern Montana (DeVelice et al. 1995), southeastern Montana (Hansen and Hoffman 1988), northwestern and west-central Wyoming (Tweit and Houston 1980), and apparently from northeastern Wyoming (Terwilliger et al. 1979a).

States/Provinces: MT:S4, WY:S3

ELEMENT SOURCES

Authors: WCS Confidence: 1 Identifier: CEGL001675

References: Bourgeron and Engelking 1994, Cooper et al. 1995, DeVelice et al. 1995, Driscoll et al. 1984, Hansen and Hoffman 1988, Hansen et al. 1984, Johnston 1987, Jorgensen 1979, Mueggler and Stewart 1980, Terwilliger et al. 1979a, Tweit and Houston 1980

\section{V.A.5.N.j. Temporarily flooded temperate or subpolar grassland V.A.5.N.J.18. PASCOPYRUM SMITHII TEMPORARILY FLOODED HERBACEOUS ALLIANCE}

\section{PASCOPYRUM SMITHII - HoRdEUM JUBATUM HERBACEOUS VEGETATION}

Western Wheatgrass - Foxtail Barley Herbaceous Vegetation

\section{ELEMENT CONCEPT}

Summary: This wheatgrass saline prairie type is found in the northern Great Plains of the United States and adjacent Canada. Stands occur in temporarily flooded sites (playas and stock ponds) with deep, poorly drained, clayey, alkaline-saline soils. Stands occur as small patches in temporarily flooded sites, surrounded by grasslands or shrublands. Grasses dominate the vegetation. Pascopyrum smithii (or Elymus lanceolatus) and Hordeum 
jubatum are the major species, and other species from the surrounding matrix vegetation may be present.

Environment: Stands of this association occupy temporarily flooded sites (playas and stock ponds) with deep, poorly drained, clayey, alkaline-saline soils. This type occurs on drawdown zones around reservoirs in eastern Montana (S. Cooper, MTNHP, pers. comm. 1998).

Vegetation: Grasses contribute most of the cover in this association, although forbs and scattered shrubs may be present. Pascopyrum smithii or Elymus lanceolatus dominate, and Hordeum jubatum contributes substantial cover. Other species may be present but contribute little cover. Stands in south-central Wyoming contain scattered Atriplex gardneri from the surrounding vegetation (Medicine Bow Mine, no date).

GRank \& Reasons: G4 (96-02-01). The G4 rank is based on a fairly broad geographic range.

Comments: Stands apparently occupy soils with higher sodium concentrations than do stands of the similar Pascopyrum smithii - Eleocharis spp. Herbaceous Vegetation (CEGL001581) (Bergman and Marcus 1976), or playas where the surface dries and the water table drops more quickly (BLM 1974). This association has not been described well. Further analysis of existing information and additional inventory will be helpful in determining the range of variation in stands of this type and how this type differs from other vegetation types of temporarily flooded sites.

\section{ELEMENT DisTRIBUTION}

Range: This wheatgrass saline prairie type is found in the northern Great Plains of the United States and adjacent Canada, extending from Colorado north to Montana and possibly Saskatchewan.

States/Provinces: CO?, MT?, ND:S?, NE?, SK?, WY:S3?

\section{ELEMENT SOURCES}

Authors: WCS Confidence: 2 Identifier: CEGL001582

References: BLM 1979b, Bergman and Marcus 1976, Bourgeron and Engelking 1994, Driscoll et al. 1984, Medicine Bow Mine Application n.d.

\section{V.A.5.N.J.11. SPARTINA PECTINATA TEMPORARILY FLOODED HERBACEOUS ALLIANCE}

SPartina PECTINATa WeStern Herbaceous Vegetation

Prairie Cordgrass Western Herbaceous Vegetation

\section{ELEMENT CONCEPT}

Summary: In Colorado, this is a tallgrass meadow comprised entirely of Spartina pectinata. Stands occurs in small swales on the plains as well as on floodplains of larger rivers. Stands of this grass have been included in other tallgrass prairie plant associations. On large river floodplains, this type occurs as distinct patches and is distinguished from adjacent riparian types by micro-topography and degree of soil saturation. Weaver (1965) reports that historically, large stands of Spartina pectinata occurred on mud flats of the Missouri River. Large stands have been observed south of Denver, now threatened by housing and golf course developments (Steve Kettler pers. comm.).

Vegetation:

GRank \& Reasons: G3? (96-02-01).

Comments: Compare this association with Spartina pectinata - Carex spp. Herbaceous Vegetation (CEGL001477).

States/Provinces: CO:S1, MT:S3?, WA:S1, WY:S?

\section{ELEMENT DISTRIBUTION}


ELEMENT SOURCES

Authors: WCS; mod. B. L. Heidel, MTNHP Confidence: 2 Identifier: CEGL001476

References: Bourgeron and Engelking 1994, Driscoll et al. 1984, Evans 1989a, Hansen and Hoffman 1988, Hansen et al. 1989, Hansen et al. 1991, Hansen et al. 1995, Kittel et al. 1996, Weaver 1965

\section{V.A.5.N.k. Seasonally flooded temperate or subpolar grassland V.A.5.N.K.56. CAREX NEBRASCENSIS SEASONALLY FLOODED HERBACEOUS ALLIANCE}

\section{CAREX NEBRASCENSIS HERBACEOUS VEGETATION}

Nebraska Sedge Herbaceous Vegetation

\section{ELEMENT CONCEPT}

Summary: These minor wetlands occur on the western Great Plains and throughout much of the western U.S. Elevation ranges from 1000-2800 m (3300-9200 feet). Stands form open meadows that occur along the margins of streambanks, flat floodplains, and lakes often forming a band along the alluvial terrace. Stands have also been sampled from marshy areas surrounding springs and below seeps on lower hillslopes. This association is often found on well-developed soil, but occurs on a wide variety of soil types ranging from saturated organics to Mollisols to Entisols. Soils tend to be fine-textured alluvium, ranging from sandy, silty loam, clay loam, or clay to organic and are typically gleyed and mottled near the surface because of the high water table most of the growing season. The vegetation is characterized by a moderately dense to dense perennial graminoid layer dominated or codominated by Carex nebrascensis (25-99\% cover), that generally forms small- to medium-sized meadows. Stands often are nearly pure Carex nebrascensis, but a variety of other graminoid species may be present such as Carex praegracilis, Calamagrostis stricta, Deschampsia caespitosa, Eleocharis palustris, Glyceria striata, Juncus balticus, Schoenoplectus pungens (= Scirpus pungens), or Triglochin maritima . Forb cover is generally low, but can be high in moist locations. Common forbs include Eurybia integrifolia (= Aster integrifolius), Geum macrophyllum, Mentha arvensis, Mimulus glabratus, and Ranunculus cymbalaria. Introduced species Poa pratensis, Poa palustris, and Melilotus officinalis may also be common.

Environment: This wetland plant association occurs on the western Great Plains and throughout much of the western U.S. Elevation ranges from 1000-2800 m (3300-9200 feet). Stands form open meadows that occur along the margins of streambanks, flat floodplains, and lakes often forming a band along the alluvial terrace. Stands have also been sampled from marshy areas surrounding springs and below seeps on lower hillslopes. This association is often found on well-developed soil, but occurs on a wide variety of soil types ranging from saturated organics to Mollisols to Entisols. Soils tend to be fine-textured alluvium, ranging from sandy, silty loam, clay loam, or clay to organic and are typically gleyed and mottled near the surface because of the high water table most of the growing season.

Vegetation: These wetlands are characterized by a moderately dense to dense perennial graminoid layer dominated or codominated by Carex nebrascensis (25-99\% cover), that generally forms small- to medium-sized meadows. Stands often are nearly pure Carex nebrascensis, but a variety of other graminoid species may be present such as Carex praegracilis, Calamagrostis stricta, Deschampsia caespitosa, Eleocharis palustris, Glyceria striata, Juncus balticus, Schoenoplectus pungens (= Scirpus pungens), or Triglochin maritima. Forb cover is generally low, but can be high in moist locations. Common forbs include Eurybia integrifolia (= Aster integrifolius), Geum macrophyllum, Mentha arvensis, Mimulus glabratus, and Ranunculus cymbalaria. Introduced species Poa pratensis, Poa palustris, and Melilotus officinalis may also be common.

In Nebraska, common species include Agrostis stolonifera, Carex hystericina, Carex pellita (= Carex lanuginosa), Eleocharis erythropoda, Equisetum spp., Juncus balticus, Schoenoplectus pungens (= Scirpus pungens), and Triglochin spp. (Steinauer and Rolfsmeier 2000).

Dynamics: In Montana, the Carex nebrascensis Community Type is considered a grazing-disclimax. Under season-long grazing, Carex nebrascensis increases in abundance, replacing former dominant species (Hansen et al. 1995). However, under extreme grazing conditions and a resulting drop in the water table, Juncus balticus or Poa pratensis can eventually replace Carex nebrascensis. In Nevada, sites dominated by Carex nebrascensis are 
considered the Potential Natural Community (Manning and Padgett 1995), which appears to be the case in undisturbed stands in Colorado.

GRank \& Reasons: G4 (96-02-01). This type is widely distributed, but many examples have been heavily grazed by cattle, lowering their floristic quality.

Comments: In the Black Hills, classification of stands was problematic due to identification problems with Carex nebrascensis and Carex aquatica. The two are difficult to distinguish based on available keys and written descriptions (Marriott and Faber-Langendoen 2000).

\section{ELEMENT DisTRIBUTION}

Range: This sedge meadow type is widely distributed from the western Great Plains into the western mountains of the United States, ranging from South Dakota and Montana to possibly as far west as Washington, south to California and east to New Mexico.

States/Provinces: AZ:S2, CA:S3, CO:S3, ID:S3, MT:S4, NE:S2, NM?, NV:SR, OR:S3?, SD:S?, UT:S3?, WA?, WY:S3

\section{ELEMENT SOURCES}

Authors: J. Drake, mod. D. Faber-Langendoen, mod. K.A. Schulz, WCS Confidence: 1 Identifier: CEGL001813

References: Baker 1982b, Bourgeron and Engelking 1994, Cooper and Cottrell 1990, Driscoll et al. 1984, Hall 1973, Hall and Hansen 1997, Hansen et al. 1988b, Hansen et al. 1991, Hansen et al. 1995, Jones 1992b, Jones and Walford 1995, Kittel et al. 1994, Kittel et al. 1996, Kittel et al. 1999, Kovalchik 1987, Manning and Padgett 1995, Marriott and Faber-Langendoen 2000, Mutz and Queiroz 1983, Padgett et al. 1988b, Padgett et al. 1989, Steinauer and Rolfsmeier 2000, Youngblood et al. 1985a, Youngblood et al. 1985b

\section{V.A.5.N.K.53. CAREX PELLITA SEASONALLY FLOODED HERBACEOUS ALLIANCE}

\section{CAREX PELLITA - CALAMAGROSTIS STRICTA HERBACEOUS VEGETATION}

Woolly Sedge - Western Bluejoint Herbaceous Vegetation

\section{ELEMENT CONCEPT}

Summary: This sedge-bluejoint wet meadow is found in the northern tallgrass prairie region and in the northeastern Great Plains. Stands occur on level ground in shallow depressions and other lowlands on poorly drained sandy, loamy, or silty clay soils. Standing water may be present for a few to several weeks during most years. Soil $\mathrm{pH}$ is circumneutral to somewhat alkaline and organic content can be moderately high. The vegetation of this community provides approximately $100 \%$ cover and the dominant vegetation is graminoids, typically 0.5 $1.0 \mathrm{~m}$ tall. Forbs can be common, but shrubs are rarely found in this type. The most abundant species are Calamagrostis stricta, Carex pellita (= Carex lanuginosa), Carex sartwellii, Anemone canadensis, Apocynum cannabinum, Symphyotrichum lanceolatum (= Aster lanceolatus), Eleocharis compressa, Juncus balticus, Phalaris arundinacea, Polygonum amphibium, and Schoenoplectus americanus (= Scirpus americanus). Carex buxbaumii may be common, except in North Dakota.

Environment: This community occurs on level ground in shallow depressions and other lowlands on poorly drained sandy, loamy, or silty clay soils. Standing water can be present for a few to several weeks a year (Dix and Smeins 1967, Smeins and Olsen 1970). Soil pH is circumneutral to somewhat alkaline, and organic content can be moderately high.

Vegetation: The vegetation of this community provides approximately $100 \%$ cover, and the dominant vegetation is graminoids, typically $0.3-1.0 \mathrm{~m}$ tall. Forbs can be common; they had $25 \%$ relative cover in the stands studied by Nelson et al. (1981). shrubs are rarely found in this type. The most abundant species are Calamagrostis stricta, Carex pellita (= Carex lanuginosa), Carex sartwellii, Anemone canadensis, Apocynum cannabinum, Symphyotrichum lanceolatum (= Aster lanceolatus), Eleocharis compressa, Juncus balticus, Phalaris 
arundinacea, Polygonum amphibium, and Schoenoplectus americanus (= Scirpus americanus). Carex buxbaumii can be common, except in North Dakota.

GRank \& Reasons: G3G5 (98-06-22).

Comments: Type concept is a little unclear. Simple dominance by Carex lanuginosa (now Carex pellita in Kartesz 1994) may not be adequate. Hydrologic placement is difficult, ranging from seasonally flooded to temporarily flooded. This type may simply be a part of Spartina pectinata - Calamagrostis stricta - Carex spp. Herbaceous Vegetation (CEGL002027) (wet prairie), or vice versa. See also Carex pellita Herbaceous Vegetation (CEGL001809).

\section{ELEMENT DISTRIBUTION}

Range: This sedge-bluejoint wet meadow is found in the northern tallgrass prairie region and in the northeastern Great Plains, ranging from northern Iowa, western Minnesota, and the Dakotas to parts of the Canadian prairie provinces.

States/Provinces: IA:SU, MB:SU, MN:S?, MT:S3?, ND:S?, SD:S?, SK:S?

\section{ELEMENT SOURCES}

Authors: J. Drake, mod. D. Faber-Langendoen, MCS Confidence: 3 Identifier: CEGL002254

References: Dix and Smeins 1967, Kartesz 1994, Nelson et al. 1981, Smeins and Olsen 1970

\section{V.A.5.N.K.61. ELEOCHARIS PALUSTRIS SEASONALLY FLOODED HERBACEOUS ALLIANCE}

ElEOCHARIS PALUSTRIS HERBACEOUS VEGETATION

Marsh Spikerush Herbaceous Vegetation

\section{ELEMENT CONCEPT}

Summary: This spikerush wet meadow community is found in the central Great Plains of the United States and Canada and in the western United States. Stands occur in small depressions in intermittent streambeds or depression ponds that flood early in the season and may dry out by summer. Stands are composed of submersed and emergent rooted vegetation under $1 \mathrm{~m}$ tall that is dominated by Eleocharis palustris, often in nearly pure stands. Soils are generally fine-textured.

Environment: This wetland occurs across the central and northwestern Great Plains and western United States. Elevations range from near sea level to $3050 \mathrm{~m}$ (in Colorado). In eastern Washington and Idaho it occurs in valleys and canyon bottoms with low-gradient streams, sloughs, and along the margins of ponds and lakes (Kovalchik 1993). In northwest Nebraska and southwest South Dakota, this community occurs in small depressions in intermittent streambeds and depression ponds that flood early in the season and dry out by summer. Soils are silty clay formed from weathered siltstone and shale (Steinauer and Rolfsmeier 1997). In southwestern South Dakota, the type occupies depression ponds in prairies (H. Marriott pers. comm. 1999). In Utah stands are described from small playas on floodplain terraces of a large river (Von Loh 2000).

In Colorado this community type occurs on the bottom of ephemeral ponds or playas (Baker and Kennedy 1985), or is associated with small to moderate-sized ponds or the edges of larger lakes and reservoirs (Bunin 1985, Padgett et al. 1989). The sites are generally only seasonally flooded, but remain moist throughout the year (Bunin 1985, Padgett et al. 1989). Elevations range from 1525-2750 m (5000-9020 feet).

The soils of Baker and Kennedy's (1985) stands were derived from Quaternary alluvium, with a heavy clay content and an average $\mathrm{pH}$ of 7.8, slightly alkaline. The soils reported by Padgett et al. (1989) were mineral soils with fine-loamy to fine particle sizes or organic. They are commonly ponded throughout the growing season and have developed from pond siltation. Hansen et al. (1988a) indicate that Eleocharis palustris is alkaline-tolerant. 
Vegetation: This wetland association is dominated by submersed and emergent rooted vegetation under $1 \mathrm{~m}$ tall and occurs across the northwestern Great Plains and western U.S. within a wide elevational range. The species composition can be quite variable, but this community is easy to recognized by the bright green, nearly pure stands of Eleocharis palustris. Vegetation cover can be sparse to dense (10-90\%), but Eleocharis palustris is the dominant species, and the only species with $100 \%$ constancy. Other species, when present, can contribute as much as $40 \%$ cover, but never exceed that of the Eleocharis palustris cover. Some of this variation is described from Colorado (Kittel et al. 1999, Baker and Kennedy 1985). Co-occurring species in low-elevation stands on the western slope can include Phalaris arundinacea (= Phalaroides arundinacea), Juncus balticus, Hordeum jubatum, Pascopyrum smithii, Schoenoplectus americanus (= Scirpus americanus), Sparganium angustifolium, species of Lemna and Potamogeton, as well as the introduced Melilotus officinalis and Bromus inermis. On the eastern plains of Colorado co-occurring species can include Leersia oryzoides, Schoenoplectus pungens (= Scirpus pungens), Panicum virgatum, Carex pellita (= Carex lanuginosa), and Spartina pectinata. At montane elevations, other graminoids, such as Carex aquatilis, Carex utriculata, and Deschampsia caespitosa are present. Forb cover is typically low, but can be occasionally abundant (30\%) in some stands. Forb species include Pedicularis groenlandica, Rhodiola integrifolia, and Caltha leptosepala.

In stands from eastern Washington, associates include Carex utriculata, Cicuta douglasii, and species of Glyceria and Potamogeton. In northwestern Nebraska, stands are dominated Eleocharis acicularis and Eleocharis palustris which commonly cover the bottoms of the pools and emerge above the water as the pools dry out. Ephemeral submersed aquatics, such as Callitriche palustris (= Callitriche verna), Potamogeton diversifolius and Marsilea vestita, may be present. As the pools dry out in mid-summer, ephemeral annual forbs, such as Limosella aquatica and Plagiobothrys scouleri, may appear. By late summer Amaranthus californicus and Gnaphalium palustre may dominate in the lowest parts of the depression (Steinauer and Rolfsmeier 1997). In southwestern South Dakota, vegetation is composed of nearly homogeneous stands of Eleocharis palustris. Other emergents, such as Polygonum amphibium, Marsilea vestita, and Eleocharis ovata, are occasionally found. Herbaceous cover is greater than $75 \%$ except in areas of deeper open water where floating and submerged aquatic plants occur, including Bacopa rotundifolia and Heteranthera limosa (H. Marriott pers. comm. 1999). In lower elevation Utah stands Glaux maritima, Distichlis spicata, and Juncus balticus were important associates (Brotherson and Barnes 1984).

Few stand data are available for Colorado examples. Generally, it appears that this community is dominated by Eleocharis palustris, forming a scattered to dense overstory, often with few associated species. Commonly associated graminoids include Hordeum jubatum and Pascopyrum smithii. Forbs present may include Atriplex argentea, Polygonum aviculare, and Rorippa sinuata (Baker and Kennedy 1985). The higher elevation stands may include a slightly different suite of species, but no stand data are available. Ramaley (1942) described a Distichlis spicata-dominated salt meadow on a lakeshore in the San Luis Valley which was ringed by Eleocharis palustris. Communities in Utah include Eleocharis acicularis and Alopecurus aequalis as likely associates (Padgett et al. 1989).

Dynamics: The hydrological regime is critically important to this association. Most stands are seasonally to permanently flooded, although some in the Great Plains occur under intermittently to temporarily flooded conditions.

Baker and Kennedy (1985) suggest that domestic livestock grazing may tend to result in increases in Hordeum jubatum, Bassia scoparia, and Polygonum aviculare. However, Hansen et al. (1988a) suggest that palatability of Eleocharis palustris is low for both domestic and wild animals, but that heavy grazing may increase this rhizomatous species and spread it onto adjacent sites. Trampling damage may occur to this type when animals heavily use the sites supporting it, particularly during drought years (Hansen et al. 1988a). Water level fluctuations over a year of greater than $1 \mathrm{~m}$ will not support this type (Hansen et al. 1988a).

GRank \& Reasons: G5 (96-02-01).

\section{ELEMENT DISTRIBUTION}

Range: This spikerush wet meadow community is found in the central Great Plains of the United States and Canada and in the western United States. 
States/Provinces: CA?, CO:S4, ID:S3, MT:S5, NE:S?, NV:SR, OR:S5, SD:S?, SK:S?, UT:S3?, WA:S?, WY:S3

ELEMENT SOURCES

Authors: D. Faber-Langendoen, mod. K. Schulz, mod. M.S. Reid, WCS Confidence: 1 Identifier: CEGL001833

References: Baker 1983c, Baker and Kennedy 1985, Billings 1945, Bourgeron and Engelking 1994, Brotherson and Barnes 1984, Bunin 1985, Driscoll et al. 1984, Ellis et al. 1979, Flowers 1962, Hall and Hansen 1997, Hansen et al. 1988a, Hansen et al. 1988b, Hansen et al. 1991, Hansen et al. 1995, Kettler and McMullen 1996, Kittel and Lederer 1993, Kittel et al. 1994, Kittel et al. 1999, Kovalchik 1987, Kovalchik 1993, Mutel 1973, Mutel and Marr 1973, Padgett et al. 1988b, Padgett et al. 1989, Penfound 1953, Ramaley 1919a, Ramaley 1942, Stearns-Roger Inc. 1978, Steinauer and Rolfsmeier 2000, Stewart 1940, Von Loh 2000, Youngblood et al. 1985a

\section{V.A.5.N.K.13. JUNCUS BALTICUS SEASONALLY FLOODED HERBACEOUS ALLIANCE}

JUNCUS BALTICUS HERBACEOUS VEGETATION

Baltic Rush Herbaceous Vegetation

\section{ELEMENT CONCEPT}

Summary: This Baltic rush wet meadow community is found widely throughout the western United States. This wet meadow vegetation occurs as small, dense patches on flat stream benches, along overflow channels, and near springs. Soils are usually sandy clay loam or fine sands and mottled or gleyed. Stands are characterized by a dense sward of Juncus balticus and often minor cover of Carex species, including Carex aquatilis, Carex praegracilis, Carex nebrascensis, or Carex utriculata. Other common species include Deschampsia caespitosa, Distichlis spicata, Glyceria striata, Hordeum jubatum, Muhlenbergia asperifolia, Phleum alpinum, and Sporobolus airoides. The introduced perennial sod grasses Poa pratensis or Agrostis stolonifera codominate some stands. Forb cover is generally low and includes wetland species like Caltha leptosepala and Dodecatheon pulchellum. Shrubs are not common. This association is often considered to be a grazing-induced community since it increases with disturbance.

Environment: This widespread herbaceous wetland community is found throughout western North America. Elevation ranges from 1420-3500 $\mathrm{m}$. Stands usually occur as small, dense patches on flat to gently sloping sites near seeps and streams. Stream channels are highly variable in size and type ranging from narrow to moderately wide, and deeply entrenched to very sinuous (Kittel et al. 1999). Soils are also variable and range from alluvial sandy and well-drained, to poorly drained silty clay loam, to organic; however, soils tend to be finer-textured, alkaline and may be saline (Brotherson and Barnes 1984, Kittel et al. 1999, Padgett et al. 1989). Cobbles and gravel are common on many sites, and gleyed and mottled horizons are often present because of flooding or high water tables (Kittel et al. 1999).

Vegetation: This association is characterized by a low $(<50 \mathrm{~cm})$, dense graminoid layer dominated by the rhizomatous perennial Juncus balticus. Minor cover of Carex species, including Carex aquatilis, Carex praegracilis, Carex nebrascensis or Carex utriculata, is often present. Other common graminoids include Deschampsia caespitosa, Distichlis spicata, Glyceria striata, Hordeum jubatum, Muhlenbergia asperifolia, Phleum alpinum, and Sporobolus airoides. Forb cover is generally low but may include Caltha leptosepala, Glaux maritima, Maianthemum stellatum, and Dodecatheon pulchellum. Shrubs are not common, but occasional Salix spp. may occur. Some stands may be codominated by the introduced perennial sod grasses Poa pratensis or Agrostis stolonifera. Other introduced species, such as Taraxacum officinale, Trifolium spp., Cirsium arvense, Lactuca serriola, Phleum pratense, and Thinopyrum intermedium, may occur in disturbed stands.

Dynamics: This association is considered by some to be a grazing-induced community because Juncus balticus is tolerant of grazing (low palatability when mature) and increases with grazing disturbance (Hansen et al. 1995, Padgett et al. 1989). Nearly pure stands of Juncus balticus may indicate that the site was heavily grazed in the past (Hansen et al. 1995). However, this association also occurs as a stable, late-seral community in areas with low disturbance (Kittel and Lederer 1993). 
GRank \& Reasons: G5 (96-02-01).

Comments: This association is often considered to be a grazing-induced community since it increases with grazing disturbance.

\section{ELEMENT DisTRIBUTION}

Range: This Baltic rush wet meadow community is found widely throughout the western United States, ranging from South Dakota and Montana west to Washington, south to possibly California, and east to New Mexico.

States/Provinces: CA?, CO:S5, ID:S5, MT:S5, NM:S4, NV:S?, OR:S5, SD:S?, UT:S3S4, WA:S3S4, WY:S3

ELEMENT SOURCES

Authors: J. Drake, mod. D. Faber-Langendoen, mod. K. Schulz, WCS Confidence: 1 Identifier: CEGL001838

References: Baker 1984a, Bourgeron and Engelking 1994, Brotherson and Barnes 1984, Bunin 1985, Driscoll et al. 1984, Faber-Langendoen 2001, Flowers 1962, Hall and Hansen 1997, Hansen et al. 1988b, Hansen et al. 1991, Hansen et al. 1995, Hess 1981, Johnston 1987, Jones and Walford 1995, Kartesz 1994, Kittel and Lederer 1993, Kittel et al. 1994, Kittel et al. 1999, Komarkova 1986, Manning 1988, Muldavin et al. 2000a, Mutel 1973, Mutz and Graham 1982, Olson and Gerhart 1982, Padgett 1982, Padgett et al. 1989, Rector 1979, Richard et al. 1996, Shupe et al. 1986, Stewart 1940, Thompson 2001, Tuhy and Jensen 1982, Von Loh 2000, Wasser and Hess 1982, Youngblood et al. 1985a

\section{V.A.5.N.K.20. PHALARIS ARUNDINACEA SEASONALLY FLOODED HERBACEOUS ALLIANCE}

Phalaris arundinacea Western Herbaceous Vegetation

Reed Canary Grass Western Herbaceous Vegetation

\section{ELEMENT CONCEPT}

Summary: This association is reported from throughout Montana, Idaho, northeastern Utah, and the Columbia Basin of Washington, but is likely more widespread in the western United States. Its distribution as a natural type is complicated because this native species is widely cultivated as a forage crop and has escaped and established in wetlands and riparian areas, displacing the local flora. Elevations range from near sea level to $1700 \mathrm{~m}$. Stands are found along riparian areas, pond and lake margins, wet meadows, and intermittent drainages. Soils are commonly fine-textured and may be flooded for brief to extended periods. The vegetation is characterized by a dense, tall herbaceous layer (often $>80 \%$ canopy cover and $1.5-2 \mathrm{~m}$ tall) that is dominated by Phalaris arundinacea, which tends to occur in monocultures. Associated species may include Equisetum arvense, Muhlenbergia asperifolia, Mentha arvensis, Schoenoplectus acutus (= Scirpus acutus), and many other species in trace amounts where disturbed. Introduced species such as Lepidium latifolium, Cirsium arvense, Sonchus oleraceus, Euphorbia esula, and Phleum pratense are common in some stands.

Environment: This association is reported from throughout Montana, Idaho, Washington and northeastern Utah, but is likely more widespread in the western United States. Elevations range from near sea level to $1700 \mathrm{~m}$. Stands are found along riparian areas, pond and lake margins, wet meadows, and intermittent drainages. Sites are flat to rolling. Soils are commonly fine-textured, but can be coarser in texture. Subsoil is often mottled and gleyed (Crawford 2001). Sites are generally flooded during the growing season, but flooding can vary from brief to extended periods.

Vegetation: This association is characterized by a dense, tall herbaceous layer (often $>90 \%$ canopy cover and 1.5 $2 \mathrm{~m}$ tall) that is dominated by Phalaris arundinacea, which tends to occur in monocultures. Associated species such as Equisetum arvense, Muhlenbergia asperifolia, Mentha arvensis, Schoenoplectus acutus (= Scirpus acutus), Polygonum amphibium, Solidago canadensis, Urtica dioica, and many other species may be present in trace amounts especially where disturbed. Occasional Populus tremuloides, Salix exigua, Rubus idaeus, or Symphoricarpos albus may be present is some stands. Introduced species such as Lepidium latifolium, Cirsium arvense, Sonchus oleraceus, Euphorbia esula, Poa pratensis, and Phleum pratense are common in some disturbed 
stands.

Dynamics: Phalaris arundinacea produces abundant herbage and is planted for livestock forage. It is tolerant of moderate grazing by livestock, although heavy grazing will reduce density (Hansen et al. 1995). Phalaris arundinacea is a threat to riparian and wetland areas because it spreads rapidly from rhizomes, dominating the sites, and is extremely difficult to remove once established (Hansen et al. 1995). Fire has been used with limited success to control the spread of Phalaris arundinacea, but the high water table where it grows makes it difficult to burn during the growing season (Hansen et al. 1995) .

Van Loh (2000) found stands growing on selenium-rich sites. It is not known if selenium is translocated into the plant tissue.

GRank \& Reasons: G5 (99-03-03).

Comments: Other natural associations included in this alliance are found throughout the northeastern United States, but this western association's distribution as a natural type is not clear because of extensive planting as a forage crop (Hansen et al. 1995, Hall and Hansen 1997). Further work is required to resolve the natural versus introduced nature of this type in western North America.

\section{ELEMENT DisTRIBUTION}

Range: This association is reported from throughout Montana and Idaho and into northeastern Utah and is likely more widespread in the western United States. Its distribution as a natural type is complicated because this native species is widely cultivated as a forage crop and has escaped and established in many wetlands and riparian areas.

States/Provinces: ID:S4?, MT:S4, NM:S4?, UT:S?

ELEMENT SOURCES

Authors: K. Schulz, WCS Confidence: 1 Identifier: CEGL001474

References: Bourgeron and Engelking 1994, Cooper et al. 1995, Crawford 2001, Driscoll et al. 1984, Hall and Hansen 1997, Hansen et al. 1995, Muldavin et al. 2000a, Von Loh 2000

\section{V.A.5.N.I. Semipermanently flooded temperate or subpolar grassland V.A.5.N.L.6. SCHOENOPLECTUS PUNGENS SEMIPERMANENTLY FLOODED HERBACEOUS ALLIANCE}

SCHOENOPLECTUS PUNGENS HERBACEOUS VEGETATION

Threesquare Herbaceous Vegetation

\section{ELEMENT CONCEPT}

Summary: This bulrush wet meadow community is found in the western United States in the intermountain basins, as well as in western parts of the Great Plains. Stands are found along low-gradient, meandering, usually perennial streams and around the margins of ponds and marshes. Schoenoplectus pungens (= Scirpus pungens) dominates the dense, 0.3 - to $0.6-\mathrm{m}$ tall herbaceous vegetation layer. Other species that often are present include Schoenoplectus maritimus (= Scirpus maritimus), Spartina gracilis, Hordeum jubatum, Pascopyrum smithii, Juncus balticus, Eleocharis palustris, Lemna minor, Sagittaria latifolia, and Typha spp. Stands of this association contain no tree or shrub layer, but a few scattered trees and shrubs may be present, most commonly Populus deltoides, Salix amygdaloides, Salix exigua, Symphoricarpos occidentalis, or Sarcobatus vermiculatus. Substrates are generally dark, organic, fine-textured soils derived from alluvium.

Environment: Stands of this widespread association are found throughout much of the western U.S. in appropriate wetland habitat. Elevations range from 1000-2400 m. Stands occur along low-gradient, meandering, usually perennial streams, around the margins of ponds and marshes, in low-lying swales, and abandoned or overflow channels where the soils remain saturated (Hansen et al. 1995, Kittel et al. 1999, Jones and Walford 1995, Walford 1996). It also occurs on silt and sand bars within the active channel. Soils are generally derived from alluvium and are fine-textured, black, alkaline, organic anoxic with gleying. Soils range from normal to saline with $\mathrm{pH}$ ranging from 7.4-9.1. 
Vegetation: This widespread wetland association is characterized by a dense, $0.3-$ to $0.6-\mathrm{m}$ tall herbaceous vegetation layer that is dominated by Schoenoplectus pungens (= Scirpus pungens). Associated species include Schoenoplectus maritimus (= Scirpus maritimus), Spartina gracilis, Hordeum jubatum, Pascopyrum smithii, Juncus balticus, Eleocharis palustris, Lemna minor, Sagittaria latifolia, and Typha spp. Stands of this association contain no tree or shrub layer, but a few scattered trees and shrubs may be present, most commonly Populus deltoides, Salix amygdaloides, Salix exigua, Symphoricarpos occidentalis, or Sarcobatus vermiculatus.

Dynamics: Stands of this association are flooded in the spring (Larson 1993).

GRank \& Reasons: G3G4 (98-04-09).

Comments: Muldavin et al. (2000a) described 5 Schoenoplectus pungens (= Scirpus pungens) community types from New Mexico. Most are codominated with an associated species listed in the vegetation description, e.g., Eleocharis palustris, Distichlis spicata, Paspalum distichum, and Equisetum laevigatum, with one being a Schoenoplectus pungens Monotype Community Type reported from the Gila River basin. Muldavin et al.'s (2000a) concept of this community type states that it can be dominated by Schoenoplectus pungens (= Scirpus pungens) or Schoenoplectus americanus (= Scirpus americanus, $=$ Scirpus olneyi). Hansen et al. (1995) also include Schoenoplectus americanus in their Scirpus pungens Habitat Type. This association needs further review to clarify whether to include stands where Schoenoplectus pungens is not the dominant species.

\section{ELEMENT DisTRIBUTION}

Range: This community is found in the western United States in the intermountain basins, as well as in western parts of the Great Plains, from Montana south to Colorado, and west into Nevada, Utah, and Wyoming.

States/Provinces: CO:S3, KS:S?, MT:S3, ND:S?, NM:S?, NV:S?, SD:S?, UT:S2S4, WY:S?

\section{ELEMENT SOURCES}

Authors: G.P. Jones, mod. K. Schulz, WCS Confidence: 2 Identifier: CEGL001587

References: Bourgeron and Engelking 1994, Brotherson and Barnes 1984, Bundy et al. 1996, Driscoll et al. 1984, Gleason and Cronquist 1991, Great Plains Flora Association 1986, Hansen et al. 1991, Hansen et al. 1995, Jones and Walford 1995, Kittel and Lederer 1993, Kittel et al. 1994, Kittel et al. 1999, Larson 1993, Lauver et al. 1999, MTNHP 1988, Muldavin et al. 2000a, Walford 1996

\section{V.A.7.N.e. Medium-tall temperate or subpolar grassland with a sparse needle-leaved or microphyllous evergreen shrub layer V.A.7.N.E.11. ARTEMISIA CANA SHRUB HERBACEOUS ALLIANCE}

Artemisia Cana SSP. Cana / Pascopyrum smithi Shrub Herbaceous Vegetation

Silver Sagebrush / Western Wheatgrass Shrub Herbaceous Vegetation

\section{ELEMENT CONCEPT}

Summary: This association has been described from the Great Plains of central and eastern Montana, far western North Dakota, northwestern South Dakota, and northeastern Wyoming. It occupies terraces and floodplains along streams, where alluvium contains more soil water than is available in the uplands. Artemisia cana ssp. cana dominates the shrub layer, which may also include small amounts of Symphoricarpos occidentalis, Sarcobatus vermiculatus, or Chrysothamnus sp. The undergrowth typically is dense and composed mainly of graminoids, with forbs contributing little cover. Pascopyrum smithii often dominates, and in many stands several other species may codominate, especially Nassella viridula, Poa pratensis, and Bromus japonicus (or another exotic, annual brome grass). Exotic grasses (Poa pratensis, Bromus japonicus) dominate the undergrowth in many stands. Bouteloua gracilis and Carex filifolia, both more typically upland species, may contribute substantial cover. Common forbs are Taraxacum spp. (exotic), Achillea millefolium, Artemisia ludoviciana, and Vicia americana.

Environment: This community is found on flat to gently sloping alluvial terraces and fans near larger creeks and rivers. Thilenius et al. (1995) found that most stands were raised at least $1 \mathrm{~m}$ above the general floodplain. Soils are formed from alluvium and are medium- to fine-textured. Flooding may occur frequently. 
Vegetation: This community is dominated by moderately dense to dense graminoids less than $1 \mathrm{~m}$ tall. Pascopyrum smithii is usually the most abundant among these. Poa pratensis, Bouteloua gracilis, and Nassella viridula are also common. Calamovilfa longifolia, Hesperostipa comata (= Stipa comata), and Achnatherum hymenoides (= Oryzopsis hymenoides) are sometimes present. Short shrubs, especially Artemisia cana and sometimes Symphoricarpos occidentalis, have $10-25 \%$ cover. Forbs and nonvascular species are generally rare.

GRank \& Reasons: G4 (00-11-29). This association seems to be common within a large geographic range, occurring from northern Montana as far south as central Wyoming, and from central Montana as far east as westcentral South Dakota. It is restricted to mesic swales, terraces and floodplains along streams of nearly any size, where soils are deep and have low to moderate amounts of salts. However, the presence of exotic species Poa pratensis and Bromus japonicus (or other annual brome grasses) in many of the stands is cause for concern. The global rank has been changed from G3? to G4. Prolonged, heavy grazing by livestock may pose a threat to this association by favoring the grazing-tolerant exotic species.

Comments: This association undoubtedly exists, but the amount of variation in species composition and vegetation structure, and the geographic range, must be better documented. It is unclear whether stands in which Nassella viridula or Elymus lanceolatus ssp. lanceolatus dominate or codominate the undergrowth should be included in this association or placed into different associations. For the Pascopyrum smithii - Nassella viridula Herbaceous Vegetation (CEGL001583), either Pascopyrum smithii or Elymus lanceolatus ssp. lanceolatus may dominate.

This community appears to be very closely related to Artemisia cana / Pascopyrum smithii Shrubland (CEGL001072) which is found in Montana, western North Dakota, and western South Dakota. The most apparent difference is the cover of shrubs. Further comparison may result in the combination of these two types.

\section{ELEMENT DISTRIBUTION}

Range: This association is known to occur from northern Montana as far south as central Wyoming, and from central Montana as far east as west-central South Dakota.

States/Provinces: MT:S?, ND:S?, SD:S?, WY:S3?

ELEMENT SOURCES

Authors: J. Drake, WCS Confidence: 1 Identifier: CEGL001556

References: Bourgeron and Engelking 1994, DeVelice et al. 1991, Driscoll et al. 1984, Hansen and Hoffman 1988, Hansen et al. 1984, Hansen et al. 1995, Jones and Walford 1995, Thilenius et al. 1995

\section{V.A.7.N.g. Medium-tall temperate or subpolar grassland with a sparse cold- deciduous shrub layer V.A.7.N.G.5. RHUS TRILOBATA SHRUB HERBACEOUS ALLIANCE}

\section{Rhus trilobata / Pseudoroegneria spicata Shrub Herbaceous Vegetation}

Ill-scented Sumac / Bluebunch Wheatgrass Shrub Herbaceous Vegetation

\section{ELEMENT CONCEPT}

Summary: This shrub prairie type is found in the United States on dry mid to upper slopes and ridgetops in the eastern plains and mountains of Wyoming and Montana. Slope and aspect are variable, but soils are consistently shallow and rocky. Herbaceous species dominate the vegetation with short shrubs and nonvascular plants present but of lesser importance. Total vegetation cover is moderate, and few plants grow taller than $1 \mathrm{~m}$. Shrubs generally have from 10-25\% cover. Rhus trilobata is the most common. It is often found with Artemisia frigida, Artemisia tridentata, Prunus virginiana, Ribes cereum, or Eriogonum spp. Pseudoroegneria spicata is the most abundant herbaceous species. Others commonly found include Koeleria macrantha, Schizachyrium scoparium, Bouteloua curtipendula, Bromus tectorum, and Opuntia polyacantha. 
Environment: This community is typically found on dry mid to upper slopes and ridgetops. It has been identified on butte tops in eastern Wyoming (Thilenius et al. 1995). Slope and aspect are variable, but soils are consistently shallow and rocky. They often form from sandstone parent materials, and rock fragments, outcrops, and bare soil cover much of the ground (Mueggler and Stewart 1978).

Vegetation: Herbaceous species dominate the vegetation with short shrubs and nonvascular plants present but of lesser importance. Total vegetation cover is moderate (Brown 1971, Thilenius et al. 1995) and few plants grow taller than $1 \mathrm{~m}$. Shrubs generally have from $10-25 \%$ cover. Rhus trilobata is the most common. It is often found with Artemisia frigida, Artemisia tridentata, Prunus virginiana, Ribes cereum, or Eriogonum spp.

Pseudoroegneria spicata is the most abundant herbaceous species. Others commonly found include Koeleria macrantha, Schizachyrium scoparium, Bouteloua curtipendula, Bromus tectorum, and Opuntia polyacantha.

GRank \& Reasons: G4 (96-02-01).

\title{
ELEMENT DisTRIBUTION
}

Range: This shrub prairie type is found in the United States on dry mid to upper slopes and ridgetops in the eastern plains and mountains of Wyoming and Montana.

States/Provinces: MT:S4, WY:S2S3

\section{ELEMENT SOURCES}

Authors: J. Drake, WCS Confidence: 1 Identifier: CEGL001120

References: Bighorn Coal Mine n.d., Bourgeron and Engelking 1994, Brown 1971, Driscoll et al. 1984, Hansen and Hoffman 1988, Mueggler and Stewart 1980, Thilenius et al. 1995, Tweit and Houston 1980

\section{V.A.7.N.n. Intermittently flooded temperate or subpolar grassland with a sparse xeromorphic (evergreen and/or deciduous) shrub layer V.A.7.N.N.1. SARCOBATUS VERMICULATUS INTERMITTENTLY FLOODED SHRUB HERBACEOUS ALLIANCE}

\author{
Sarcobatus Vermiculatus / Pascopyrum SMithit - (Elymus lanceolatus) Shrub \\ HERBACEOUS VEGETATION \\ Black Greasewood / Western Wheatgrass - (Streamside Wild Rye) Shrub Herbaceous Vegetation
}

\section{ELEMENT CONCEPT}

Summary: This greasewood shrub prairie is found in saline habitats in the northwestern Great Plains of the United States and Canada. Stands occur on flat to gently sloping alluvial fans, terraces, lakebeds, and floodplains. The soil is usually deep clay, silty clay, sandy clay, or loam, although coarse soils are possible. They are saline or alkaline, but salt crusts on the surface are typically absent. Parent material is usually alluvium. This community has moderate to dense vegetation cover. Medium-tall $(0.5-1.5 \mathrm{~m})$ shrubs are scattered throughout with a total shrub canopy of $10-25 \%$. The shrub layer is dominated by Sarcobatus vermiculatus, with Artemisia tridentata, Atriplex confertifolia, and Chrysothamnus viscidiflorus in smaller amounts. Symphoricarpos occidentalis and Rhus aromatica are sometimes found in more mesic microhabitats within this community. Herbaceous cover is sparse beneath the shrubs and otherwise moderate to dense. The dominant species are typically $0.5-1 \mathrm{~m}$ tall. The most abundant species is Pascopyrum smithii, usually accompanied by Bouteloua gracilis, Bromus japonicus, Bromus tectorum, and Hesperostipa comata (= Stipa comata). Few forbs are found in this community. Achillea millefolium and Opuntia polyacantha are the only species with high constancy. Overall species diversity in this community is low.

Environment: This community is found on flat to gently sloping alluvial fans, terraces, lakebeds, and floodplains (Mueggler and Stewart 1978, Hansen and Hoffman 1988). Dodd and Coupland (1966) found Sarcobatus vermiculatus in association with Pascopyrum smithii only on the most arid parts of southwestern Saskatchewan. The soil is usually deep clay, silty clay, sandy clay, or loam (Hirsch 1985, Jones and Walford 1995), although coarse soils are possible (USFS 1992, Thilenius et al. 1995). They are saline or alkaline, but salt crusts on the 
surface are absent (Thilenius et al. 1995, but see Steinauer and Rolfsmeier 2000). Parent material is usually alluvium. Flooding during the spring is possible.

Vegetation: This community has moderate to dense vegetation cover (Jones and Walford 1995, Thilenius et al. 1995). Medium-tall (0.5-1.5 m) shrubs are scattered throughout, with a total shrub canopy of $10-25 \%$ (Hansen and Hoffman 1988, USFS 1992). The shrub layer is dominated by Sarcobatus vermiculatus, with Atriplex confertifolia, Atriplex canescens, Atriplex argentea, Artemisia tridentata, and Chrysothamnus viscidiflorus in smaller amounts. Symphoricarpos occidentalis and Rhus aromatica are sometimes found in more mesic microhabitats within this community (Hirsch 1985). Herbaceous cover is sparse beneath the shrubs and moderate to dense in between. The dominant species are typically $0.5-1 \mathrm{~m}$ tall. The most abundant species is Pascopyrum smithii, usually accompanied by Bouteloua gracilis, Bromus japonicus, Bromus tectorum, and Hesperostipa comata (= Stipa comata). Few forbs are found in this community. Achillea millefolium and Opuntia polyacantha are the only species with high constancy. Other species present may include Grindelia squarrosa. Overall species diversity in this community is low (Hansen and Hoffman 1988, Von Loh et al. 1999). In Nebraska, shrub species cover may be very low, and saline pockets may contain Distichlis spicata and Sporobolus airoides. Astragalus bisulcatus may be prominent (Steinauer and Rolfsmeier 2000).

GRank \& Reasons: G4 (96-02-01).

Comments: Compare this association with Sarcobatus vermiculatus / Elymus elymoides - Pascopyrum smithii Shrubland (CEGL001365) from New Mexico.

See Steinauer and Rolfsmeier (2000) for a description of the stands in Nebraska. Sarcobatus vermiculatus / Distichlis spicata - (Puccinellia nuttalliana) Shrub Herbaceous Vegetation (CEGL002146) may be a more saline version of this type.

\section{ELEMENT DisTRIBUTION}

Range: This greasewood shrub prairie is found in saline habitats in the northwestern Great Plains of the United States and Canada, ranging from northwestern Nebraska north to the Dakotas and Saskatchewan.

States/Provinces: MT:S4, ND:S4?, NE:S2, SD:SU, SK?, WY:S4

\section{ELEMENT SOURCES}

Authors: J. Drake, WCS Confidence: 1 Identifier: CEGL001508

References: Bourgeron and Engelking 1994, Brown 1971, Dodd and Coupland 1966, Driscoll et al. 1984, Earth Resource Technology n.d., Fisser et al. 1965, Hamner 1964, Hansen and Hoffman 1988, Hansen et al. 1984, Hirsch 1985, Johnston 1987, Jones and Walford 1995, MTNHP 1988, Mueggler and Stewart 1980, Olson and Gerhart 1982, Steinauer and Rolfsmeier 2000, Thilenius et al. 1995, USFS 1992, Von Loh et al. 1999 


\section{SPARSE VEGETATION \\ VII.C.4.N.a. Soil slumps or landslides \\ VII.C.4.N.A.400. ERIOGONUM PAUCIFLORUM SPARSE VEGETATION ALLIANCE}

ERIOGONUM PAUCIFLORUM - GUTIERREZIA SAROTHRAE BADLANDS SPARSE VEGETATION

Small-flower Wild Buckwheat - Snakeweed Badlands Sparse Vegetation

\section{ELEMENT CONCEPT}

Summary: This badlands type is found in the northwestern Great Plains, in badlands topography. In Badlands National Park, South Dakota, stands occur on eroded formations of Cretaceous Pierre shale, Oligocene Brule siltstone and Chadron clayey mudstone and shale, and Miocene Arickaree sandstone. Brule formation siltstone is often capped by Rocky Ford volcanic ash and may also contain veins of chalcedony. Soils are undeveloped, poor, loose, and easily eroded. The topography is typically flat, and stands occur on erosional outwash fans.

Structurally, stands rarely exceed $10 \%$ vegetative cover and is often less than $5 \%$. On level terrain, the vegetation is relatively evenly distributed, but on steeper slopes and cliffs the vegetation may grow in patches and in rows or seams. In Badlands National Park, plant species that are nearly always present include the dwarf-shrubs Eriogonum pauciflorum, Gutierrezia sarothrae, Opuntia polyacantha, Atriplex argentea, Cryptantha thyrsiflora, and the forb Grindelia squarrosa. Atriplex canescens dwarf-shrubs were observed throughout the type, but were typically short-statured and scattered in distribution.

Environment: In Badlands National Park, South Dakota, this type is typically found on silty/sandy outwash fans newly deposited by eroding badlands formations. These formations include Cretaceous Pierre shale, Oligocene Brule siltstone and Chadron clayey mudstone and shale, and Miocene Arickaree sandstone. Soils are undeveloped, poor, loose, and easily eroded. The topography is typically flat, and stands occur on erosional outwash fans. One stand, comprised of four-wing saltbush, occupies a large badlands flat and erosion fan (Von Loh et al. 1999).

Vegetation: This badlands community type rarely exceeds $10 \%$ vegetative cover and is often less than $5 \%$. On level terrain, the vegetation is relatively evenly distributed, but on steeper slopes and cliffs the vegetation may grow in patches and in rows or seams. In Badlands National Park, plant species that are nearly always present include the dwarf-shrubs Eriogonum pauciflorum, Gutierrezia sarothrae, Opuntia polyacantha, Atriplex argentea, and Cryptantha thyrsiflora, and the forb Grindelia squarrosa. Atriplex canescens dwarf-shrubs were observed throughout the type, but were typically short-statured and scattered in distribution (Von Loh et al. 1999).

GRank \& Reasons: G4G5 (00-01-31). In Badlands National Park, South Dakota, this community type occupies badland formations, which cover approximately $45 \%$ of the park (Von Loh et al. 1999). It is probably found in other badlands habitats in the Northern Great Plains.

High-ranked species: In Montana, much of the habitat for Astragalus barrii falls within this association.

\section{ELEMENT DiSTRIBUTION}

Range: This badlands type is found in the northwestern Great Plains in badlands topography or on azonal soils in other than badlands-dominated landscapes.

States/Provinces: MT?, ND:S?, SD:S?

ELEMENT SOURCES

Authors: D. Faber-Langendoen, MCS; mod. B. L. Heidel, MTNHP Confidence: 3 Identifier: CEGL005270

References: Von Loh et al. 1999 


\section{Plant Community Descriptions — Literature Cited}

Aldous, A. E., and H. L. Shantz. 1924. Types of vegetation in the semiarid portion of the United States and their economic significance. Journal of Agricultural Research 28(2):99-128.

Baker, W. L. 1982b. Natural vegetation of the Piceance Basin, Colorado. Appendix D, pages 1-113 in: J. S. Peterson and W. L. Baker, editors. Inventory of the Piceance Basin, Colorado. Unpublished report for the Bureau Land Management, Craig, CO.

Baker, W. L. 1983c. Natural vegetation of part of northwestern Moffat County, Colorado. Unpublished report prepared for the State of Colorado Natural Areas Program, Department of Natural Resources, Denver by Colorado Natural Heritage Inventory, Denver.

Baker, W. L. 1984a. A preliminary classification of the natural vegetation of Colorado. Great Basin Naturalist 44 (4):647-676.

Baker, W. L., and S. C. Kennedy. 1985. Presettlement vegetation of part of northwestern Moffat County, Colorado, described from remnants. Great Basin Naturalist 45(4):747-777.

Barnes, P. W., A. T. Harrison, and S. P. Heinisch. 1984. Vegetation patterns in relation to topography and edaphic variation in Nebraska Sandhills prairie. Prairie Naturalist 16(4):145-158.

Bear Creek Uranium Mine Application. No date. Unpublished report No. 399 prepared for Wyoming Department of Environmental Quality, Land Quality Division, Cheyenne, WY.

Bellah, R. G., and L. C. Hulbert. 1974. Forest succession on the Republican River floodplain in Clay County, Kansas. Southwestern Naturalist 19(2):155-166.

Bergman, H. L., and M. D. Marcus, editors. 1976. Final environmental assessment, Black Thunder Mine Site, Campbell County, Wyoming. Volume II (Text) and Volume III (Appendix). University of Wyoming Black Thunder Research Team.

Bighorn Coal Mine. No date. Application No. 213-T2, on file at Wyoming Department of Environmental Quality, Land Quality Division, Cheyenne.

Billings, W. D. 1945. The plant associations of the Carson Desert region, western Nevada. Butler University Botanical Studies 7:89-123.

Blackburn, W. H. 1967. Plant succession on selected habitat types in Nevada. Unpublished thesis. University of Nevada, Reno. 162 pp.

Blackburn, W. H., P. T. Tueller, and R. E. Eckert, Jr. 1968a. Vegetation and soils of the Mill Creek Watershed. Nevada Agricultural Experiment Station Bulletin R-43. Reno. 69 pp.

Blackburn, W. H., P. T. Tueller, and R. E. Eckert, Jr. 1968b. Vegetation and soils of the Crowley Creek Watershed. Nevada Agricultural Experiment Station Bulletin R-42. Reno. 60 pp.

Blackburn, W. H., P. T. Tueller, and R. E. Eckert, Jr. 1969a. Vegetation and soils of the Cow Creek Watershed. Nevada Agricultural Experiment Station Bulletin R-49. Reno. 80 pp.

Blackburn, W. H., P. T. Tueller, and R. E. Eckert, Jr. 1969c. Vegetation and soils of the Churchill Canyon Watershed. Nevada Agricultural Experiment Station Bulletin R-45. Reno. 157 pp.

Blackburn, W. H., P. T. Tueller, and R. E. Eckert, Jr. 1971. Vegetation and soils of the Rock Springs Watershed. Nevada Agricultural Experiment Station Bulletin R-83. Reno. 116 pp.

BLM [Bureau of Land Management]. 1979b. Final environmental impact statement, proposed development of coal resources in Eastern Powder River, WY. 67 pp.

Boggs, K. W. 1984. Succession in riparian communities of the lower Yellowstone River, Montana. M.S. thesis. Montana State University, Bozeman. 107 pp. 
Bourgeron, P. S., and L. D. Engelking, editors. 1994. A preliminary vegetation classification of the western United States. Unpublished report. The Nature Conservancy, Western Heritage Task Force, Boulder, CO. 175 pp. plus appendix.

Brotherson, J. D., and S. J. Barnes. 1984. Habitat relationships of Glaux maritima in central Utah. Great Basin Naturalist 44(2):299-309.

Brotherson, J. D., and W. T. Brotherson. 1981. Grazing impacts on the sagebrush communities of central Utah. Great Basin Naturalist 41(3):335-340.

Brown, R. W. 1971. Distribution of plant communities in southeastern Montana badlands. The American Midland Naturalist 85(2):458-477.

Bruner, W. E. 1931. The vegetation of Oklahoma. Ecological Monographs 1:99-188.

Bundy, R. M., J. V. Baumgartner, M. S. Reid, P. S. Bourgeron, H. C. Humphries, and B. L. Donohue. 1996. Ecological classification of wetland plant associations in the Lahontan Valley, Nevada. Prepared for Stillwater National Wildlife Refuge and USDI Fish \& Wildlife Service. 53 pp. not including inventories, tables and graphs.

Bunin, J. E. 1985. Vegetation of the City of Boulder, Colorado open space lands. Report prepared for the City of Boulder, Real Estate/Open Space, Boulder, CO. 114 pp.

Burgess, R. L. 1965. A study of plant succession in the sandhills of southeastern North Dakota. Proceedings of the North Dakota Academy of Science 19:62-80.

Butler, J., and H. Goetz. 1986. Vegetation and soil-landscape relationships in the North Dakota Badlands. The American Midland Naturalist 116(2):278-386.

CDM Consultants. No date. Dave Johnston Mine Application No. 291-T2. On file at Wyoming Department of Environmental Quality, Land Quality Division, Cheyenne.

Christensen, E. M., and S. L. Welsh. 1963. Presettlement vegetation of the valleys of western Summit and Wasatch counties, Utah. Proceedings of the Utah Academy of Science, Arts and Letters 40:163-174.

Christy, S. 1973. An analysis of the woody vegetation on the South Platte River flood plain in northeastern Colorado. Unpublished thesis. University of Northern Colorado, Greeley. 82 pp.

Clark, S. J. V. 1977b. The vegetation of Rocky Flats, Colorado. Unpublished thesis. University of Colorado, Boulder.

Clark, S. V., P. J. Webber, V. Komarkova, and W. A. Weber. 1980. Map of mixed prairie grassland vegetationRocky Flats, Colorado. University of Colorado, Institute of Arctic and Alpine Research Occasional Paper 35. $66 \mathrm{pp}$.

Clausnitzer, R. R., and B. A. Zamora. 1987. Forest habitat types of the Colville Indian Reservation. Unpublished report prepared for the Department of Forest and Range Management, Washington State University, Pullman. $110 \mathrm{pp}$.

Cooper, D. J., and T. R. Cottrell. 1990. Classification of riparian vegetation in the northern Colorado Front Range. Unpublished report prepared for The Nature Conservancy, Colorado Field Office, Boulder. 115 pp.

Cooper, S. V., and R. D. Pfister. 1985. Forest habitat types of the Crow and Northern Cheyenne Indian Reservations. Unpublished termination report prepared for Bureau of Indian Affairs, Billings Area Office by USDA Forest Service, Intermountain Forest and Range Experiment Station, Ogden, UT. 118 pp.

Cooper, S. V., K. E. Neiman, R. Steele, and D. W. Roberts. 1987. Forest habitat types of northern Idaho: A second approximation. USDA Forest Service, Intermountain Research Station. General Technical Report INT-236. Ogden, UT. 135 pp. [reprinted in 1991]

Cooper, S. V., P. Lesica, R. L. DeVelice, and T. McGarvey. 1995. Classification of southwestern Montana plant communities with emphasis on those of Dillon Resource Area, Bureau of Land Management. Montana Natural Heritage Program, Helena, MT. 154 pp. 
Cooper, S., K. Neiman, and R. Steele. 1985. Forest habitat types of northern Idaho. Editorial draft. Unpublished report prepared for USDA Forest Service, Intermountain Forest and Range Experiment Station, and Region One, Missoula, MT. 295 pp.

Cooper, S.V. and C. Jean. 2001. Wildfire succession in plant communities natural to the Alkali Creek vicinity, Charles Russell National Wildlife National Wildlife Refuge, Montana. Unpublished report to the U.S. Fish and Wildife Service. Montana Natural Heritage Program, Helena. 32 pp. plus appendices.

Costello, D. F., and H. E. Schwan. 1946. Conditions and trends on ponderosa pine ranges in Colorado. USDA Forest Service Mimeograph. 33 pp.

Cotter-Ferguson Project. No date. Application No. 490. On file at Wyoming Department of Environmental Quality, Land Quality Division, Cheyenne.

Cowardin, L. M., V. Carter, F. C. Golet, and E. T. LaRoe. 1979. Classification of wetlands and deepwater habitats of the United States. U.S. Fish and Wildlife Service, Biological Service Program. FWS/OBS-79/31. Washington, DC. 103 pp.

Crawford, R. C. 2001. Initial riparian and wetland classification and characterization of the Columbia Basin in Washington. Prepared for Environmental Protection Agency and Bureau of Land Management, Spokane District. Washington Natural Heritage Program, Washington Department of Natural Resources, Olympia. 83 pp.

Culwell, L. D., and K. L. Scow. 1982. Terrestrial vegetation inventory: Dominy Project Area, Custer County, Montana 1979-1980. Unpublished technical report for Western Energy Company by Westech, Helena, MT. 144 pp. plus 15 pp. appendix.

Culwell, L.D., K.Scow, and L.A. Larson, 1986. A preliminary Evaluation of the Vegetation of the Makoshika State Park Area, Dawson County, Montana. Prepared by Western Technology and Engineering, Inc for Montana Department of Fish, Wildlife and Parks, Helena MT.

Currie, P. O. 1975. Grazing management of ponderosa pine - bunchgrass ranges of the central Rocky Mountains: The status of our knowledge. USDA Forest Service, Rocky Mountain Forest and Range Experiment Station. Research Paper RM-159. Fort Collins, CO. 24 pp.

Daubenmire, R. 1952. Forest vegetation of northern Idaho and adjacent Washington, and its bearing on concepts of vegetation classification. Ecological Monographs 22(4):301-330.

Daubenmire, R. F. 1970. Steppe vegetation of Washington. Washington State University Agricultural Experiment Station Technical Bulletin No. 62. 131 pp.

Daubenmire, R. F., and J. B. Daubenmire. 1968. Forest vegetation of eastern Washington and northern Idaho. Washington State University Agricultural Experiment Station Technical Bulletin No. 60. 104 pp.

Despain, D. G. 1973a. Vegetation of the Big Horn Mountains, Wyoming, in relation to substrate and climate. Ecological Monographs 43(3):329-354.

DeVelice, R. L., J. Lichthardt, and P. S. Bourgeron. 1991. A preliminary classification of the plant communities of northeastern Montana. Prepared for the Montana Natural Heritage Program. Helena, MT. 144 pp.

DeVelice, R. L., S. V. Cooper, J. T. McGarvey, J. Lichthardt, and P. S. Bourgeron. 1995. Plant communities of northeastern Montana: A first approximation. Montana Natural Heritage Program, Helena, MT. 116 pp.

Dix, R. L., and F. E. Smeins. 1967. The prairies, meadows, and marsh vegetation of Nelson County, North Dakota. Canadian Journal of Botany 45:21-58.

Dodd, J. D., and R. T. Coupland. 1966. Vegetation of saline areas in Saskatchewan. Ecology 47(6):958-968.

Driscoll, R. S., D. L. Merkel, D. L. Radloff, D. E. Snyder, and J. S. Hagihara. 1984. An ecological land classification framework for the United States. USDA Forest Service. Miscellaneous Publication No. 1439. Washington, DC. 56 pp. 
Earth Resource Technology. No date. Vanguard II Mine Application No. 334-T2. On file at Wyoming Department of Environmental Quality, Land Quality Division, Cheyenne.

Ellis, S. L., T. Shoemaker, and R. Sanz. 1979. Inventories of plants, birds, mammals, reptiles, and amphibians of the Unaweep Canyon Springs, Mesa County, Colorado. Unpublished report prepared for Colorado Natural Areas Program, Department of Natural Resources, Denver.

Ellis, S., and P. Hackney. 1981. Vegetation baseline report: Clear Creek property. Unpublished report prepared for Chevron Shale Oil Co., Denver, CO, by Environmental Research and Technology Inc. Fort Collins, CO.

Ellison, L., and E. J. Woolfolk. 1937. Effects of drought on vegetation near Miles City, Montana. Ecology 18:329-336.

Evans, S. 1989a. Riparian survey of Washington's Columbia Basin. Unpublished report prepared for The Nature Conservancy Washington Natural Heritage Program, Olympia, Washington.

Evenden, A. G. 1990. Ecology and distribution of riparian vegetation in the Trout Creek Mountains of southeastern Oregon. Ph.D. dissertation. Oregon State University, Corvallis. 156 pp.

Faber-Langendoen, D., editor. 2001. Plant communities of the Midwest: Classification in an ecological context. Association for Biodiversity Information, Arlington, VA. 61 pp. plus appendix (705 pp.).?

Fisher, W. C. and B. D. Clayton. 1983. Fire ecology of Montana forest habitat types east of the continental divide. General Technical Report INT-141. Intermountain Forest and Range Experiment Station, Ogden, Utah.

Fisser, H. G. 1964. Range survey in Wyoming's Big Horn Basin of Wyoming. Wyoming Agricultural Experiment Station Bulletin 424.

Fisser, H. G., J. R. Wight, J. R. Flesland, and L. D. Robinson. 1965. Halogeton research, 1964 results. University of Wyoming Cooperative Research Report to the USDI Bureau of Land Management, Sections I-VI. Wyoming Agricultural Experiment Station. Mimeographed Circular pages 1-82. University of Wyoming, Laramie.

Flowers, S. 1962. Vegetation of Morrow Point and Blue Mesa Reservoir basins of the upper Gunnison River, Colorado. Pages 47-102 in: A. M. Woodbury, editor. Ecological studies of the flora and fauna of the Curecanti Reservoir Basins, western Colorado. University of Utah, Anthropological Papers No. 59 (Upper Colo. Series No. 8).

Foti, T., M. Blaney, X. Li, and K. G. Smith. 1994. A classification system for the natural vegetation of Arkansas. Proceedings of the Arkansas Academy of Science 48:50-53.

Francis, R. E. 1983. Sagebrush-steppe habitat types in northern Colorado: A first approximation. Pages 67-71 in: Proceedings of the Workshop on Southwestern habitat types. USDA Forest Service, Southwestern Region, Albuquerque, NM.

Ganskopp, D. C. 1979. Plant communities and habitat types of the Meadow Creek Experimental Watershed. Unpublished thesis. Oregon State University, Corvallis. 162 pp.

Girard, M. M., H. Goetz, and A. J. Bjugstad. 1989. Native woodland habitat types of southwestern North Dakota. USDA Forest Service, Rocky Mountain Forest and Range Experiment Station. Research Paper RM-281. Fort Collins, CO. 36 pp.

Gleason, H. A., and A. Cronquist. 1991. Manual of vascular plants of northeastern United States and adjacent Canada. New York Botanical Garden, Bronx, NY. 910 pp.

Godfread, C. 1994. The vegetation of the Little Missouri Badlands of North Dakota. Pages 17-24 in: Proceedings of the Leafy Spurge Strategic Planning Workshop, March 29-30, Dickinson, ND.

Great Plains Flora Association. 1986. Flora of the Great Plains. University Press of Kansas, Lawrence. 1402 pp.

Greenall, J. A. 1995. Draft element descriptions for natural communities of southern Manitoba (prairie and parkland regions). Manitoba Conservation Data Centre, Winnipeg. 17 pp. 
Hall, F. C. 1967. Vegetation-soil relations as a basis for resource management on the Ochoco National Forest of central Oregon. Unpublished dissertation. Oregon State University, Corvallis. 207 pp.

Hall, F. C. 1973. Plant communities of the Blue Mountains in eastern Oregon and southeastern Washington. USDA Forest Service, Pacific Northwest Region. R6 Area Guide 3-1. 62 pp.

Hall, J. B., and P. L. Hansen. 1997. A preliminary riparian habitat type classification system for the Bureau of Land Management districts in southern and eastern Idaho. Riparian and Wetland Research Program, School of Forestry, University of Montana. Idaho Bureau of Land Management, Technical Bulletin No. 97-11. 381 pp.

Hamner, R. W. 1964. An ecological study of Sarcobatus vermiculatus communities of the Big Horn Basin, Wyoming. Unpublished thesis. University of Wyoming, Laramie.

Hansen, P. L. 1985. An ecological study of the vegetation of the Grand River/Cedar River, Sioux, and Ashland districts of the Custer National Forest. Unpublished dissertation. South Dakota State University. 257 pp.

Hansen, P. L., and G. R. Hoffman. 1988. The vegetation of the Grand River/Cedar River, Sioux, and Ashland districts of the Custer National Forest: A habitat type classification. USDA Forest Service, Rocky Mountain Forest and Range Experiment Station. General Technical Report RM-157. Fort Collins, CO. 68 pp.

Hansen, P. L., G. R. Hoffman, and A. J. Bjugstad. 1984. The vegetation of Theodore Roosevelt National Park, North Dakota: A habitat type classification. USDA Forest Service, Rocky Mountain Forest and Range Experiment Station. General Technical Report RM-113. Fort Collins, CO. 35 pp.

Hansen, P. L., K. Bogs, R. Pfister, and J. Joy. 1990. Classification and management of riparian and wetland sites in central and eastern Montana. Draft version 2. Montana Riparian Association, Montana Forest and Conservation Experiment Station, School of Forestry. University of Montana, Missoula, MT. 279 pp.

Hansen, P. L., R. B. Hopkins, and G. R. Hoffman. 1980. An ecological study of Theodore Roosevelt National Park: Habitat types and their animal components. Department of Biology, University of South Dakota, Vermillion. $182 \mathrm{pp}$.

Hansen, P. L., R. D. Pfister, K. Boggs, B. J. Cook, J. Joy, and D. K. Hinckley. 1995. Classification and management of Montana's riparian and wetland sites. Montana Forest and Conservation Experiment Station, School of Forestry, University of Montana, Miscellaneous Publication No. 54. 646 pp.

Hansen, P. L., S. W. Chadde, and R. D. Pfister. 1988b. Riparian dominance types of Montana. University of Montana Miscellaneous Publication 49. Montana Forest and Conservation Experiment Station, Missoula. $411 \mathrm{pp}$.

Hansen, P., K. Boggs, and R. Pfister. 1991. Classification and management of riparian and wetland sites in Montana. Unpublished draft version prepared for Montana Riparian Association, Montana Forest and Conservation Experiment Station, School of Forestry, University of Montana, Missoula. 478 pp.

Hansen, P., R. Pfister, J. Joy, D. Svoboda, K. Boggs, L. Myers, S. Chadde, and J. Pierce. 1989. Classification and management of riparian sites in southwestern Montana. Unpublished draft prepared for the Montana Riparian Association, School of Forestry, University of Montana, Missoula. 292 pp.

Hansen, P., S. Chadde, R. Pfister, J. Joy, D. Svoboda, J. Pierce, and L. Myers. 1988a. Riparian site types, habitat types, and community types of southwestern Montana. Draft Version 1. Montana Riparian Association, Missoula.

Hanson, H. C., and E. Dahl. 1956. Some grassland communities in the mountain-front zone in northern Colorado. Vegetatio 7:249-270.

Hanson, H. C., and W. Whitman. 1938. Characteristics of major grassland types in western North Dakota. Ecological Monographs 8:58-114.

Heerwagen, A. 1958. Management as related to range site in the central plains of eastern Colorado. Journal of Range Management 11:5-9. 
Jones, G. P. 1990. Initial study of deciduous woodlands and thickets at Devil's Tower National Monument. Report submitted to the National Park Service, Devil's Tower National Monument, under order number PX1390-9-0073. Wyoming Natural Diversity Database, Laramie.

Jones, G. P., and G. M. Walford. 1995. Major riparian vegetation types of eastern Wyoming. Submitted to Wyoming Department of Environmental Quality, Water Quality Division. Wyoming Natural Diversity Database, Laramie, WY. 245 pp.

Jorgensen, H. E. 1979. Vegetation of the Yellow Water Triangle, Montana. Montana Department of Fish and Game, in cooperation with the Bureau of Land Management. Helena, MT. 57 pp.

Kartesz, J. T. 1994. A synonymized checklist of the vascular flora of the United States, Canada, and Greenland. Second edition. Volume 1--Checklist. Timber Press, Portland, OR. 622 pp.

Kartesz, J. T. 1999. A synonymized checklist and atlas with biological attributes for the vascular flora of the United States, Canada, and Greenland. First edition. In: J. T. Kartesz and C. A. Meacham. Synthesis of the North American Flora. Version 1.0. North Carolina Botanical Garden, Chapel Hill, NC.

Kaul, R. B., Challaiah, and K. H. Keeler. 1983. Effects of grazing and juniper-canopy closure on the prairie flora in Nebraska high-plains canyons. Pages 95-105 in: Proceedings of the Seventh North American Prairie Conference (1980).

Keammerer, W. R. 1987. Bentonite regional vegetation study. Prepared for Crook County Bentonite Producers and Wyoming Department of Environmental Quality, Land Quality Division, by Stoeker-Keammerer and Associates, Boulder, CO.

Kettler, S., and A. McMullen. 1996. Routt National Forest riparian vegetation classification. Report prepared for Routt National Forest by the Colorado Natural Heritage Program, Colorado State University, Fort Collins.

Kittel, G. M., and N. D. Lederer. 1993. A preliminary classification of the riparian vegetation of the Yampa and San Miguel/Dolores river basins. Unpublished report prepared for Colorado Department of Health and the Environmental Protection Agency by The Nature Conservancy, Colorado Field Office, Boulder.

Kittel, G., E. Van Wie, M. Damm, R. Rondeau, S. Kettler, and J. Sanderson. 1999. A classification of the riparian plant associations of the Rio Grande and Closed Basin watersheds, Colorado. Unpublished report prepared by the Colorado Natural Heritage Program, Colorado State University, Fort Collins.

Kittel, G., R. Rondeau, and A. McMullen. 1996. A classification of the riparian vegetation of the Lower South Platte and parts of the Upper Arkansas River basins, Colorado. Submitted to Colorado Department of Natural Resources and the Environmental Protection Agency, Region VIII. Prepared by Colorado Natural Heritage Program, Fort Collins. 243 pp.

Kittel, G., R. Rondeau, N. Lederer, and D. Randolph. 1994. A classification of the riparian vegetation of the White and Colorado River basins, Colorado. Final report submitted to Colorado Department of Natural Resources and the Environmental Protection Agency. Colorado Natural Heritage Program, Boulder. 166 pp.

Knight, D. H., G. P. Jones, Y. Akashi, and R. W. Myers. 1987. Vegetation ecology in the Bighorn Canyon National Recreation Area. Unpublished report prepared for the USDI National Park Service and University of Wyoming-National Park Service Research.

Komarkova, V. 1986. Habitat types on selected parts of the Gunnison and Uncompahgre national forests. Unpublished final report prepared for USDA Forest Service, Rocky Mountain Forest and Range Experiment Station. Fort Collins, CO. 270 pp. plus appendices.

Komarkova, V. K., R. R. Alexander, and B. C. Johnston. 1988b. Forest vegetation of the Gunnison and parts of the Uncompahgre National Forests: A preliminary habitat type classification. USDA Forest Service. Research Paper RM-163. 65 pp.

Kooiman, M., and Y. B. Linhart. 1986. Structure and change in herbaceous communities of four ecosystems in the Front Range Colorado, USA. Arctic and Alpine Research 18(1):97-110.

Kovalchik, B. L. 1987. Riparian zone associations - Deschutes, Ochoco, Fremont, and Winema national forests. USDA Forest Service Technical Paper 279-87. Pacific Northwest Region, Portland, OR. 171 pp. 
Kovalchik, B. L. 1993. Riparian plant associations on the national forests of eastern Washington - Draft version 1. USDA Forest Service, Colville National Forest, Colville, WA. 203 pp.

Kuchler, A. W. 1964. Potential natural vegetation of the conterminous United States. Special Publication \#36. American Geographical Society. New York, NY. (Manual to Accompany the map - 115 pp.)

Larson, G. E. 1993. Aquatic and wetland vascular plants of the northern Great Plains. USDA Forest Service General Technical Report RM-238. Rocky Mountain Forest and Range Experiment Station, Fort Collins, CO. $681 \mathrm{pp}$.

Lauver, C. L., K. Kindscher, D. Faber-Langendoen, and R. Schneider. 1999. A classification of the natural vegetation of Kansas. The Southwestern Naturalist 44:421-443.

Lesica, P., and R. L. DeVelice. 1992 Plant communities of the Pryor Mountains. Preliminary report prepared by the Montana Natural Heritage Program, Helena, MT.

Lewis, M. E. 1975. Plant communities of the Jarbidge Mountain Complex, Humboldt National Forest. Unpublished report compiled for USDA Forest Service, Region IV, Ogden, UT. 22 pp.

Livingston, R. B. 1947. An ecological study of the Black Forest region and adjacent plains. Unpublished dissertation. Duke University, Durham, NC. 134 pp.

Livingston, R. B. 1949. An ecological study of the Black Forest, Colorado. Ecological Monographs 19:123-144.

Looman, J. 1980. The vegetation of the Canadian prairie provinces. II. The grasslands, Part 1. Phytocoenologia 8(2):153-190.

Manning, M. 1988. Ecology and rooting characteristics of four intermountain meadow community types. Unpublished thesis. University of Nevada, Reno.

Manning, M. E., and W. G. Padgett. 1995. Riparian community type classification for Humboldt and Toiyabe National Forests, Nevada and eastern California. USDA Forest Service, Intermountain Region. 306 pp.

Marr, J. W., and D. L. Buckner. 1974. Colorado to Wyoming pipeline corridor study. Unpublished report for Colony Development Operation, Atlantic Richfield Co., Denver by Thorne Ecological Institute, Boulder, CO. $79 \mathrm{pp}$.

Marriott, H. J., and D. Faber-Langendoen. 2000. The Black Hills community inventory. Volume 2: Plant community descriptions. The Nature Conservancy, Midwest Conservation Science Center and Association for Biodiversity Information, Minneapolis, MN. 326 pp.

Martin, B., S. Cooper, B. Heidel, T. Hildebrand, G. Jones, D. Lenz, and P. Lesica. 1998. Natural community inventory within landscapes in the Northern Great Plains Steppe Ecoregion of the United States. Unpublished report to the Natural Resource Conservation Service, Northern Plains Regional Office. The Nature Conservancy, Montana Field Office, Helena. 211pp.

Mauk, R. L., and J. A. Henderson. 1984. Coniferous forest habitat types of northern Utah. USDA Forest Service. General Technical Report INT-170. Intermountain Forest and Range Experiment Station, Ogden, UT. 89 pp.

McAdams, A. G., D. A. Stutzman, and D. Faber-Langendoen. 1998. Black Hills Community Inventory, unpublished data. The Nature Conservancy, Midwest Regional Office, Minneapolis, MN.

McLean, A. 1970. Plant communities of the Similkameen Valley, British Columbia, and their relationships to soils. Ecological Monographs 40(4):403-424.

Medicine Bow Mine Application. No date. Application No. 331-T1. On file at Wyoming Department of Environmental Quality, Land Quality Division, Cheyenne.

Meyer, M. I. 1985. Classification of native vegetation at the Woodworth Station, North Dakota. Prairie Naturalist 17(3):167-175.

Mine Reclamation Consultants. 1977. Buckskin Mine Application No. 500-T2. On file at Wyoming Department of Environmental Quality, Land Quality Division, Cheyenne. 
Moretti, M. C. 1979. Vegetation and soil factors in relation to slope position: A study of plant communities on foothill knolls in the Uintah Basin of Utah. Unpublished thesis. Brigham Young University, Provo. 31 pp.

Moretti, M. C., and J. D. Brotherson. 1982. Vegetation and soil factors in relation to slope position of foothill knolls in the Uinta Basin of Utah. Great Basin Naturalist 42(1):81-90.

MTNHP [Montana Natural Heritage Program]. 1988. Draft guide to the natural vegetation of Montana. Montana Natural Heritage Program, Helena. 389 pp.

MTNHP [Montana Natural Heritage Program]. No date. Unpublished data on file. Helena, MT.

Mueggler, W. F., and W. L. Stewart. 1980. Grassland and shrubland habitat types of western Montana. USDA Forest Service. General Technical Report INT-66. Intermountain Forest and Range Experiment Station. Ogden, UT. 154 pp.

Muldavin, E., P. Durkin, M. Bradley, M. Stuever, and P. Mehlhop. 2000a. Handbook of wetland vegetation communities of New Mexico: Classification and community descriptions (volume 1). Final report to the New Mexico Environment Department and the Environmental Protection Agency prepared by the New Mexico Natural Heritage Program, University of New Mexico, Albuquerque, NM.

Mutel, C. F. 1973. An ecological study of the plant communities of certain montane meadows in the Front Range of Colorado. Unpublished thesis. University of Colorado, Boulder. $77 \mathrm{pp}$.

Mutel, C., and J. W. Marr. 1973. A vegetative study of three montane herbaceous basins. Journal of the Colorado-Wyoming Academy of Science 7(4):28. (Abstract)

Mutz, K. M., and J. Queiroz. 1983. Riparian community classification for the Centennial Mountains and South Fork Salmon River, Idaho. Unpublished report prepared for USDA Forest Service Intermountain Region under contract 53-84M8-2-0048 by Meiiji Resource Consultants, Layton, UT. 168 pp.

Mutz, K. M., and R. Graham. 1982. Riparian community type classification-Big Piney Range District, Wyoming. Unpublished report prepared for USDA Forest Service, Intermountain Region under contract 53-84M8-1974, by Meiiji Resource Consultants, Layton, UT. 88 pp.

NatureServe. 2002. International Classification of Ecological Communities: Terrestrial Vegetation. Natural Heritage Central Databases. NatureServe, Arlington, VA.

Nelson, J. R. 1961. Woody plant communities in the badlands of western North Dakota. Proceedings of the North Dakota Academy of Science 15:42-44.

Nelson, W. T., W. T. Barker, and H. Goetz. 1981. Habitat type classification of grasslands of Sheyenne National Grassland of southeastern North Dakota. Completion Report for Cooperative Agreement No. RM-80-139CA. Unpublished report. 138 pp.

Ode, Dave. Personal communication. South Dakota Natural Heritage Program, Pierre, SD.

Olson, R. A., and W. A. Gerhart. 1982. A physical and biological characterization of riparian habitat and its importance to wildlife in Wyoming. Unpublished report prepared for Wyoming Fish and Game Department, Cheyenne, WY. 188 pp.

Padgett, W. G. 1982. Ecology of riparian plant communities in southern Malheur National Forest. Unpublished thesis. Oregon State University, Corvallis. $143 \mathrm{pp}$.

Padgett, W. G., A. P. Youngblood, and A. H. Winward. 1988b. Riparian community type classification of Utah. USDA Forest Service, Intermountain Region Publication R4-ECOL-88-01. Ogden, UT.

Padgett, W. G., A. P. Youngblood, and A. H. Winward. 1989. Riparian community type classification of Utah and southeastern Idaho. USDA Forest Service, Intermountain Region. Report R4-ECOL-89-01. Ogden, UT. $191 \mathrm{pp}$.

Penfound, W. T. 1953. Plant communities of Oklahoma lakes. Ecology 34:561-583. 
Pfister, R. D. 1977. Ecological classification of forest land in Idaho and Montana. Pages 329-358 in: Proceedings of Ecological Classification of Forest Land in Canada and Northwestern USA, University of British Columbia, Vancouver.

Pfister, R. D., B. L. Kovalchik, S. F. Arno, and R. C. Presby. 1977. Forest habitat types of Montana. USDA Forest Service. General Technical Report INT-34. Intermountain Forest and Range Experiment Station, Ogden, UT. 174 pp.

Phillips, C. M. 1977. Willow carrs of the upper Laramie River Valley, Colorado. Unpublished thesis. Colorado State University, Fort Collins. 71 pp.

Poulton, C. E. 1955. Ecology of the non-forested vegetation in Umatilla and Morrow counties, Oregon. Unpublished dissertation. State College of Washington, Pullman. $166 \mathrm{pp}$.

Ramaley, F. 1916b. Dry grassland of a high mountain park in northern Colorado. The Plant World 19(4):249270.

Ramaley, F. 1919a. The role of sedges in some Colorado plant communities. American Journal of Botany 6:120130.

Ramaley, F. 1919b. Some mountain plant communities of sandy soil. The Plant World 22(11):313-329.

Ramaley, F. 1939b. Sand-hill vegetation of northeastern Colorado. Ecological Monographs 9:1-51.

Ramaley, F. 1942. Vegetation of the San Luis Valley in southern Colorado. University of Colorado Studies, Series D, 1:231-277.

Rector, C. D. 1979. Lower Gunnison River Basin wetland inventory and evaluation. Unpublished thesis. University of Colorado, Boulder. $71 \mathrm{pp}$.

Reed, M. J. and R.A. Peterson. 1961. Vegetation, Soil, and Cattle Responses to Grazing on Northern Great Plains Range. USDA, FS. Technical Bulletin No. 1252. December 1961.

Richard, C., G. Kittel, and S. Kettler. 1996. A classification of the riparian vegetation of the San Juan National Forest. Draft 1 report. Colorado Natural Heritage Program, Colorado State University, Fort Collins.

Roberts, D. W. 1980. Forest habitat types of the Bear's Paw Mountains and Little Rocky Mountains, Montana. Unpublished thesis. Department of Forestry, University of Montana, Missoula. 116 pp.

Roberts, D. W., J. I. Sibbernsen, and R. D. Pfister. 1979. Forest and woodland habitat types of north-central Montana. Vol. 2: The Missouri River breaks. School of Forestry, University of Montana. IFRES for Bureau of Land Management, State Office, Res. Div., Billings, Montana. Order \# YA-512-CT6-84. 24 pp.

Shanks, D. L. 1977. Aerial photo densitometry for rangeland planning and evaluation. Unpublished thesis. Colorado State University, Fort Collins. 66 pp.

Shupe, J. B., J. D. Brotherson, and S. R. Rushforth. 1986. Patterns of vegetation surrounding springs in Goshen Bay, Utah County, Utah, U.S.A. Hydrobiologia 139:97-107.

Skull Point Mine Application. No date. Application No. 2335-T2. On file at Wyoming Department of Environmental Quality, Land Quality Division, Cheyenne.

Skull Point Mine Permit Renewal. No date. On file at Wyoming Department of Environmental Quality, Land Quality Division, Cheyenne.

Smeins, F. E., and D. E. Olsen. 1970. Species composition and production of a native northwestern Minnesota tall grass prairie. The American Midland Naturalist 84(2):398-410.

Soil Conservation Service. 1978. Range site descriptions for Colorado. Technical Guide, Section II-E. USDA Soil Conservation Service, Colorado State Office, Denver.

Stearns-Roger, Inc. 1978. Rawhide Energy Project. Transmission system, ecological investigations. Volume II. Technical baseline report to Platte River Power Authority. 51 pp. 
Steele, R., R. D. Pfister, R. A. Ryker, and J. A. Kittams. 1981. Forest habitat types of central Idaho. USDA Forest Service General Technical Report INT-114. Intermountain Forest and Range Experiment Station, Ogden, UT. 138 pp.

Steinauer, G. 1989. Characterization of the natural communities of Nebraska. Appendix D, pages 103-114 in: M. Clausen, M. Fritz, and G. Steinauer. The Nebraska Natural Heritage Program, two year progress report. Unpublished document. Nebraska Game and Parks Commission, Natural Heritage Program, Lincoln, NE.

Steinauer, G., and S. Rolfsmeier. 2000. Terrestrial natural communities of Nebraska. Unpublished report of the Nebraska Game and Parks Commission. Lincoln, NE. 143 pp.

Stewart, B. K. 1940. Plant ecology and paleoecology of the Creede Valley, Colorado. Unpublished dissertation. University of Colorado, Boulder. $154 \mathrm{pp}$.

Strong, L. L. 1980. Estimating phytomass production of habitat types on sagebrush steppe. Unpublished thesis. Colorado State University, Fort Collins. 133 pp.

Sweetwater Uranium Project. 1978. Application No. 481. On file at Wyoming Department of Environmental Quality, Land Quality Division, Cheyenne.

Taylor, J. E. and T. L. Holst. 1976. Grass and shrub plant community classification. USFS Contract Research Project 26-3494, Final Report, Ashland District, US Forest Service.

Terwilliger, C., K. Hess, and C. Wasser. 1979a. Key to the preliminary habitat types of Region 2. Addendum to initial progress report for habitat type classification. USDA Forest Service, Rocky Mountain Forest and Range Experiment Station. Fort Collins, CO.

Thilenius, J. F. 1970. An isolated occurrence of limber pine (Pinus flexilis James) in the Black Hill of South Dakota. The American Midland Naturalist 84(2):411-417.

Thilenius, J. F. 1972. Classification of the deer habitat in the ponderosa pine forest of the Black Hills, South Dakota. USDA Forest Service Research Paper RM-91. Rocky Mountain Forest and Range Experiment Station, Fort Collins, CO. 28 pp.

Thilenius, J. F., and D. R. Smith. 1985. Vegetation and soils of an alpine range in the Absaroka Mountains, Wyoming. USDA Forest Service General Technical Report RM-121. Rocky Mountain Forest and Range

Thilenius, J. F., and G. R. Brown. 1990. Vegetation on semi-arid rangelands, Cheyenne River Basin, Wyoming. Unpublished report prepared for USDA Forest Service, Rocky Mountain Forest and Range Experiment Station, Laramie, WY. 147 pp.

Thilenius, J. F., G. R. Brown, and A. L. Medina. 1995. Vegetation on semi-arid rangelands, Cheyenne River Basin, Wyoming. USDA Forest Service. General Technical Report RM-GTR-263. Rocky Mountain Forest and Range Experiment Station, Fort Collins, CO. 60 pp.

Thompson, J. 2001. Draft vegetation associations of Zion National Park, Utah. Prepared for Association for Biodiversity Information, Boulder.

Tiedemann, J. A., R. E. Francis, C. Terwilliger, Jr., and L. H. Carpenter. 1987. Shrub-steppe habitat types of Middle Park, Colorado. USDA Forest Service Research Paper RM-273. Rocky Mountain Forest and Range Experiment Station, Fort Collins, CO. 20 pp.

Tisdale, E. W. 1947. The grasslands of the southern interior of British Columbia. Ecology 28(4):346-382.

Tisdale, E. W., and A. McLean. 1957. The Douglas fir zone of southern British Columbia. Ecological Monographs 27:247-266.

Tolstead, W. L. 1941. Plant communities and secondary succession in south-central South Dakota. Ecology 22 (3):322-328.

Tolstead, W. L. 1942. Vegetation of the northern part of Cherry County, Nebraska. Ecological Monographs 12 (3):257-292. 
Heidel, B. 1984a. Proposed North Dakota natural inventory community classification structure. Memo, North Dakota Parks and Recreation Department, Bismarck, ND. 19 pp.

Heidel, B. L. 1997. Preliminary Botanical Survey in the Tongue River Area, Montana. Unpublished report. Montana Natural Heritage Program, Helena. 11 pp. plus appendices and map.

Heidel, B., S. V. Cooper and C. Jean. 2000. Plant species of special concern and plant associations of Sheridan County, Montana. Report to U.S. Fish and Wildlife Service. Montana Natural Heritage Program, Helena. 22 pp. plus appendices.

Heinze, D. H., R. E. Eckert, and P. T. Tueller. 1962. The vegetation and soils of the Steptoe Watershed. Unpublished report prepared for the USDI Bureau of Land Management. $40 \mathrm{pp}$.

Hess, K. 1981. Phyto-edaphic study of habitat types of the Arapaho-Roosevelt National Forest, Colorado. Unpublished dissertation. Colorado State University, Fort Collins. 558 pp.

Hironaka, M., M. A. Fosberg, and A. H. Winward. 1983. Sagebrush-grass habitat types of southern Idaho. Forestry, Wildlife, and Range Experiment Station Bulletin No. 15, University of Idaho, Moscow. 44 pp.

Hirsch, K. J. 1985. Habitat type classification of grasslands and shrublands of southwestern North Dakota. Ph.D. thesis. North Dakota State University, Fargo.

Hoagland, B. 2000. The vegetation of Oklahoma: A classification for landscape mapping and conservation planning. The Southwestern Naturalist 45(4):385-420.

Hoagland, B. W. 1998. Oklahoma riparian vegetation. In: A. Fallon and M. Smolen, editors. Riparian area management handbook. Publication number E-952. Oklahoma Cooperative Extension Service, Oklahoma State University, Stillwater.

Hoagland, B. W. 1998a. Classification of Oklahoma vegetation types. Working draft. University of Oklahoma, Oklahoma Natural Heritage Inventory, Norman. 43 pp.

Hoffman, G. R., and R. R. Alexander. 1976. Forest vegetation of the Bighorn Mountains, Wyoming: A habitat type classification. USDA Forest Service Research Paper RM-170. Rocky Mountain Forest and Range Experiment Station, Fort Collins, CO. 38 pp.

Hoffman, G. R., and R. R. Alexander. 1987. Forest vegetation of the Black Hills National Forest of South Dakota and Wyoming: A habitat type classification. USDA Forest Service, Rocky Mountain Forest and Range Experiment Station. Research Paper RM-276. Fort Collins, CO. 48 pp.

Hubbard, W. A. 1950. The climate, soils, and soil-plant relationships of an area in southwestern Saskatchewan. Scientific Agriculture 30(8):327-342.

Johnson, C. G., and R. R. Clausnitzer. 1992. Plant associations of the Blue and Ochoco Mountains. USDA Forest Service, Pacific Northwest Region, Wallowa-Whitman National Forest. R6-ERW-TP-036-92. 163 pp. plus appendices.

Johnson, C. G., and S. A. Simon. 1985. Plant associations of the Wallowa Valley Ranger District, Part II: Steppe. USDA Forest Service, Pacific Northwest Region, Wallowa-Whitman National Forest. 258 pp.

Johnson, C. G., Jr., and S. A. Simon. 1987. Plant associations of the Wallowa-Snake Province Wallowa-Whitman National Forest. USDA Forest Service, Pacific Northwest Region, Wallowa-Whitman National Forest. Technical Paper R6-ECOL-TP-255A-86. 399 pp. plus appendices.

Johnson, P., K. Boggs, R. Pfister, and J. Joy. 1990a. Classification and management of riparian and wetland sites in central and eastern Montana. Draft version 2. Montana Riparian Association, Montana Forest and Conservation Experiment Station, School of Forestry, University of Montana, Missoula, MT.

Johnston, B. C. 1987. Plant associations of Region Two: Potential plant communities of Wyoming, South Dakota, Nebraska, Colorado, and Kansas. R2-ECOL-87-2. USDA Forest Service, Rocky Mountain Region. Lakewood, CO. 429 pp.

Jones, G. 1992b. Wyoming plant community classification (Draft). Wyoming Natural Diversity Database, Laramie, WY. 183 pp. 
Tuhy, J. S., and S. Jensen. 1982. Riparian classification for the Upper Salmon and Middle Fork Salmon River drainages, Idaho. Unpublished report prepared for the USDA Forest Service, Intermountain Region by White Horse Associates, Smithfield, UT. 183 pp.

Tweit, S., and K. Houston. 1980. Grassland and shrubland habitat types of the Shoshone National Forest. USDA Forest Service, Rocky Mountain Region, Shoshone National Forest.

USFS [U.S. Forest Service]. 1992. Draft habitat types of the Little Missouri National Grasslands. Medora and McKenzie ranger districts, Custer National Forest. Dickinson, ND..

Vanderhorst, J., Cooper, S. V. and B. Heidel. 1998. Botanical and vegetation survey of Carter County, Montana. Unpublished report to Bureau of Land Management. Montana Natural Heritage Program, Helena. 116 pp. + app.

Von Loh, J. 2000. Draft local descriptions of the vegetation associations of Ouray National Wildlife Refuge. USGS Bureau of Reclamation, Remote Sensing and GIS Group, Denver Federal Center, Denver.

Von Loh, J., D. Cogan, D. Faber-Langendoen, D. Crawford, and M. Pucherelli. 1999. USGS-NPS Vegetation Mapping Program, Badlands National Park, South Dakota. USDI Bureau of Reclamation. Technical Memorandum No. 8260-99-02. Denver, CO.

Walford, G. M. 1996. Statewide classification of riparian and wetland dominance types and plant communities Bighorn Basin segment. Report submitted to the Wyoming Department of Environmental Quality, Land Quality Division by the Wyoming Natural Diversity Database. $185 \mathrm{pp}$.

Wasser, C. H., and K. Hess. 1982. The habitat types of Region II. USDA Forest Service: A synthesis. Final report prepared for USDA Forest Service, Rocky Mountain Forest and Range Experiment Station, Fort Collins, CO. 140 pp.

Weaver, J. E. 1965. Native vegetation of Nebraska. University of Nebraska Press, Lincoln. 185 pp.

Weaver, J. E., and F. W. Albertson. 1956. Grasslands of the Great Plains: Their nature and use. Johnsen Publishing Co., Lincoln, NE. 395 pp.

Williams, C. K., and T. R. Lillybridge. 1983. Forested plant associations of the Okanogan National Forest. USDA Forest Service, Pacific Northwest Region. R6-Ecol-132b-1983. 140 pp.

Williams, C. K., and T. R. Lillybridge. 1985. Forested plant associations of the Colville National Forest. Draft. Unpublished field guide prepared for USDA Forest Service.

Wilson, R. E. 1970. Succession in stands of Populus deltoides along the Missouri River in southeastern South Dakota. The American Midland Naturalist 83(2):330-342.

Youngblood, A. P., W. G. Padgett, and A. H. Winward. 1985a. Riparian community type classification of eastern Idaho-western Wyoming. USDA Forest Service, Intermountain Region. R4-Ecol-85-01. Ogden, UT. 78 pp.

Youngblood, A. P., W. G. Padgett, and A. H. Winward. 1985b. Riparian community type classification of northern Utah and adjacent Idaho. Unpublished report prepared for USDA Forest Service, Intermountain Region, Ogden, UT. 104 pp.

Zamora, B. A. 1983. Forest habitat types of the Spokane Indian Reservation. Agricultural Research Center, Washington State University Research Bulletin XB-0936-1983. 